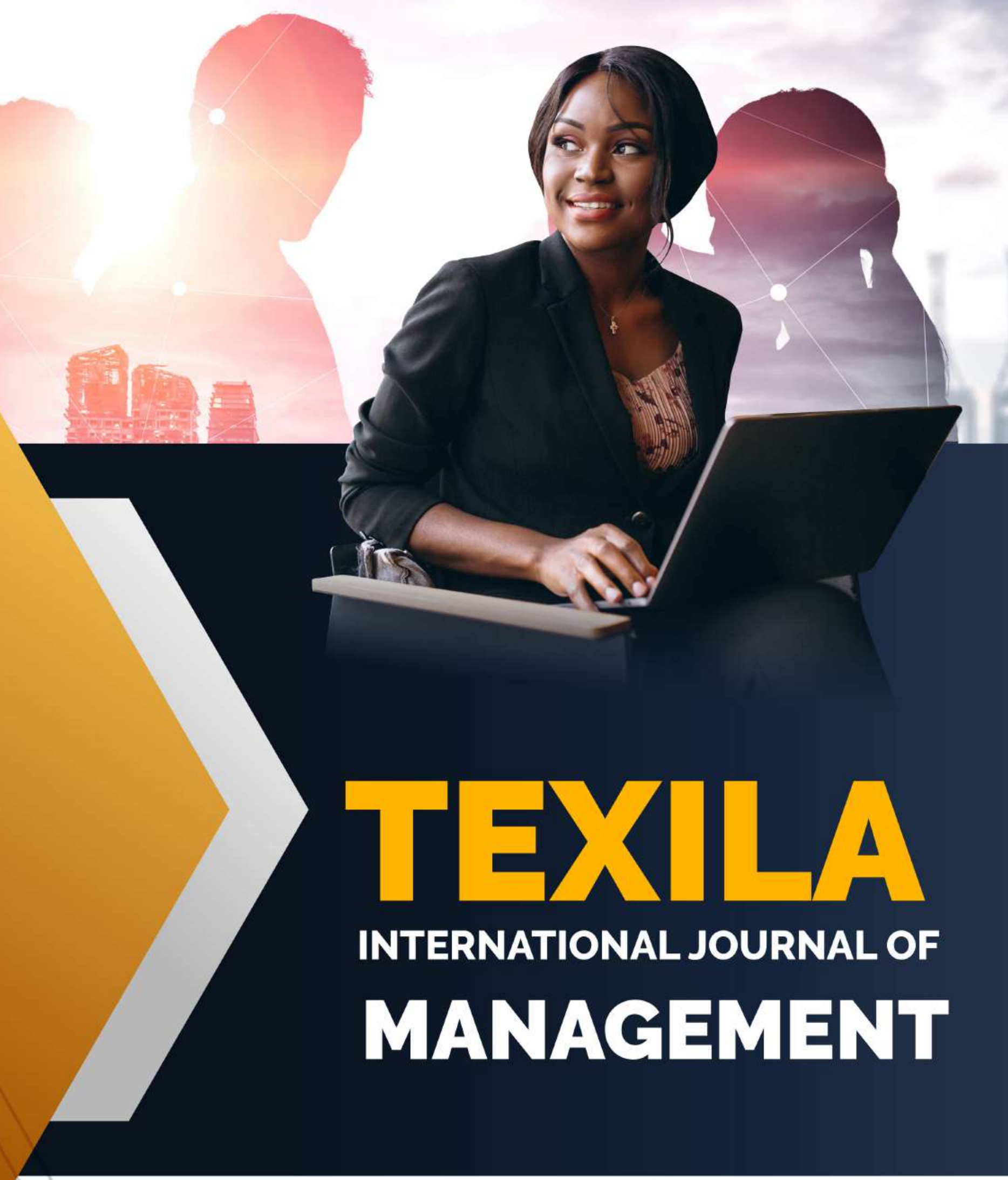

Volume 8 | Issue $1 \quad$ ISSN: 2520-310X 


\section{EDITORIAL POLICY}

Papers must be submitted with the understanding that they have not been published elsewhere (except in the form of an abstract or as part of a published lecture, review, or thesis) and are not currently under consideration by another journal published or any other publisher. The submitting (Corresponding) author is responsible for ensuring that the article's publication has been approved by all the other coauthors. It is also the authors' responsibility to ensure that the articles coming from a particular institution are submitted with the approval of the necessary institution. Only an acknowledgment from the editorial office officially establishes the date of receipt. It is a condition for submission of a paper that the authors permit editing of the paper for readability. All enquiries concerning the publication of accepted papers should be addressed to ejournal.assist@tau.edu.gy.

\section{CHIEF EDITOR}

Dr.Sumanta Dutta, Assistant Professor, St. Xavier College.

\section{EDITORIAL BOARD MEMBERS}

Dr. S. Rheeta Marjery, Director Research, KV Institute of Management.

Dr. Madhu Bala, Department of Commerce, D.A.V. College for Girls.

Dr. Abraham, Professor, Synergy University, Dubai Campus.

Dr. C.B. Venkata Krishna Prasad, Dayananda Sagar College of Arts, Science and Commerce, India. 


\section{ABOUT PLAGIARISM}

Plagiarism is the use or close imitation of the language and ideas of another author and representation of them as one's own original work. Duplicate publication, sometimes called self-plagiarism, occurs when an author reuses substantial parts of his or her own published work without providing the appropriate references. This can range from getting an identical paper published in multiple journals, where authors add small amounts of new data to a previous paper.

Plagiarism can be said to have clearly occurred when large chunks of text have been cut and pasted. Such manuscripts would not be considered for publication in TIJMG Journal. But minor plagiarism without dishonest intent is relatively frequent, for example when an author reuses parts of an introduction from an earlier paper. The editors will judge any case of which they become aware (either by their own knowledge of and reading about the literature, or when alerted by referees) on its own merits.

The paper containing the plagiarism will be obviously returned back to the authors for review, but we earnestly request the authors to avoid submitting plagiarized 


\section{DISCLAIMER}

Texila International Journal of Management (TIJMG) make every effort to ensure the accuracy of all the information (the "Content") contained in its publications. However, the TIJMG and its agents make no representations or warranties whatsoever as to the accuracy, completeness or suitability for any purpose of the Content and disclaim all such representations and warranties whether express or implied to the maximum extent permitted by law. Any views expressed in this publication are the views of the authors and are not necessarily the views of the Editor's or Texila International Journal of Management. 


\section{TABLE OF CONTENT}

1 Customer Satisfaction in the Retail Sector of Botswana

Misani Sephetsolo

2 The Impact of Social Media on 21st Century Businesses Growth: A Case Study -

Background Check International Limited, Nigeria

Alexander Kolawole Olugbodi

3 The Electronic Payment Systems in a Developing Economy with Reference to Guyana

Imran Khan

The Potential of Technology within the Agribusiness Industry in the Emerging Market of Ghana

Richard Asante

5 The Effect of Corporate Reputation on the Performance of Corporate

Organizations in Developing Countries: Evidence from West Africa

Kingsley Nwagu

6 Application of the Deming PDSA Cycle as a Patient Experience Management Tool to Improve HIV Care. An Action Research in Under-Resourced Settings of Jinja-Uganda

Balidawa John

7 Impact of Communication in the Management of Revenue Collection in Onitsha Metropolitan Area, Anambra State of Nigeria

Joseph Brown

8 Opportunities and Constraints within the Agribusiness Industry in the Emerging Market of Ghana

Richard Asante

9 Strategy Behind the Business Success of Amazon: A Case Study 
10 Gender and Perceived Usefulness of e-HRM Technologies. A Case of the

Bankers' Experience in Tanzania

Judith Namabira

11 The Strategic Impact of Total Quality Management on Customer Satisfaction. A

Case Study of Colour Fiesta Nigeria Limited

Gladys Harold-Juwah

12 Health Budget Allocation and Performance; and the Budget's Preparedness for Health Events such as COVID-19: Enugu State Perspective

Simon Nnamdi Eneh

13 Citizen Participation in Health Budget Process: Trends and Patterns with Particular Reference to Enugu State of Nigeria

Simon Nnamdi Eneh 


\title{
Customer Satisfaction in the Retail Sector of Botswana
}

\author{
Misani Sephetsolo \\ Ph.D. in Management, Texila American University, Botswana, Gaborone
}

\begin{abstract}
This paper examined the level of customer satisfaction within the retail sector of Botswana. In making this examination, the paper utilised the large retail chain stores, specifically, Choppies, PnP, Shoprite, and Spar, within Gaborone. This means that this paper undertook a survey concentrating on 4 retail giants in Botswana from which a sample of 750 customers was sampled using convenience sampling for participation in the study. The findings from this study show that the level of customer satisfaction in Botswana was good (rating score $=3.87 / 5$ ). The significant contributors to customer satisfaction were gender, product quality, product diversity, pricing, responsiveness, design and appearance, and customer experience. The paper recommended that retailers focus on strategic pricing for enhanced customer satisfaction in the sector, adopt quality and diversity-centric policies, and adopt robust customer knowledge management and customer experience management.
\end{abstract}

Keywords: Age, Appearance, Customer service, Customer experience, Customer satisfaction, Design, Gender, Location, Product quality, Pricing, Product diversity, Responsiveness.

\section{Introduction}

The global business community has, in the recent past, revolutionized the extent to which organizations currently concern themselves with issues around going concerned first before growth and profitability [1]. With this in mind, service organizations across the geographical and sectoral divide can differentiate themselves from their competitors based on the quality of the service they deliver [2].

A Study [3] argues that customer satisfaction and quality of service delivery are twin paths when it comes to creating value for both the organization and the customers. The author observed that a retailing organization that offers poor quality of service risks losing its credibility and erodes its confidence in the eyes of the customers. The impact of this is reflected in the poor customer satisfaction returns. While the retailers are concerned with offering goods and services to their diverse customers, their survival and profitability are tied to the customer experience and the creation of value for the customers [4].

The retail sector is one of the many business sectors whose success is predicated not only on its ability to offer goods and services to the customers but also on its ability to satisfy the diverse needs of the customers [5]. In this regard, the retail sector exists to offer goods and services and do so in a satisfactory manner which in essence means that the success of players within the sector rests on the ability of the retailers to offer optimal customer satisfaction [6]. While the food and grocery retailing sector is part of the fast-moving consumer goods (FMCG) sector, it is essential to underscore that globally, the sector is highly competitive, and survival is service delivery and customer satisfaction based [7]. Effective service delivery within the FMCG sector depends on how the retailers understand their customers' needs and satisfactorily deliver on them based on their level and quality of customer knowledge [8]. 
Therefore, the retail sector is such that the retailing organizations capitalize on their relationships with their clients, which is a function of the level of customer experience and the subsequent level of customer satisfaction [8].

In the context of Botswana, retailing is regarded as the second largest provider of employment after the mining sector and, in the same manner, contributes significantly (approximately 29\%) to the country's GDP [9]. In this regard, approximately $40.5 \%$ of the informal sector businesses in Botswana are found within the retail and wholesale trade [10]. The dominant players within the country's FCMG food and groceries sector are large retail chain supermarkets such as Pick n Pay, Choppies, Shoprite, Spar, Woolworths, and Game. These jointly control a significant portion of the market. In this study, the level of customer satisfaction was assessed using customers within the significant chain retail stores of Botswana, given the geographical presence and the size of the market that these control.

The objectives of this study were:

1. To determine the level of customer satisfaction in Botswana's FMCG food and groceries sector.

2. To examine the correlation between customer satisfaction factors and customer experience and customer satisfaction.

3. To evaluate the impact of customer experience on customer satisfaction.

4. To examine the impact of customer satisfaction factors on customer satisfaction.

To respond to the above research objectives, the following research hypotheses were tested:

$\mathbf{H}_{1}$ : The gender of the customers has a statistically significant impact on the level of customer satisfaction.

$\mathbf{H}_{2}$ : The age of the customers has a statistically significant impact on the level of customer satisfaction.

$\mathbf{H}_{3}$ : Product quality has a statistically significant impact on the level of customer satisfaction.
$\mathbf{H}_{4}$ : Product diversity has a statistically significant impact on the level of customer satisfaction.

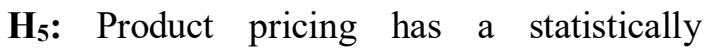
significant impact on the level of customer satisfaction.

$\mathbf{H}_{6}$ : Responsiveness of the organization has a statistically significant impact on the level of customer satisfaction.

$\mathbf{H}_{7}$ : The location of the retail outlets has a statistically significant impact on the level of customer satisfaction.

$\mathbf{H}_{8}$ : Physical design and appearance of the retail outlet have a statistically significant impact on the level of customer satisfaction.

$\mathbf{H}_{9}$ : Customer experience has a statistically significant impact on the level of customer satisfaction.

\section{Literature Review}

\section{theoretical Framework}

This resource-based theory is the theoretical foundation anchoring this study. According to [11], the resource-based theory argues that possessing strategic resources provides an organization with a golden opportunity to develop competitive advantages over its rivals. These competitive advantages, in turn, can help the organization enjoy significant profits. According to [12], a strategic resource is an asset that is valuable, rare, difficult to imitate and has no substitutable. A resource is valuable to the extent that it helps a firm create strategies that capitalize on opportunities and ward off threats. [11] posit that firms align their resources, skills, and expertise into core competence to gain a competitive edge against their competitors. Core competencies, in this case, are the activities that an organization does better than its competitors [13]. These core competencies can include how well an organization can adapt to technological changes and advancement in ICT to further its service delivery. A strategy acts as an integral part of the firm's goals and objectives; strategy serves as a plan of action that links together with an organization's key goals, policies, and action 
sequences towards achieving the vision and the vision.

A well-aligned strategy to the organization's goals and objectives plays an essential role in assembling and allocating an organization's resources into a viable setting based on the organizational capabilities, external environment, and contingent moves by their competitors. [11] defines a strategy as a plan of action designed to achieve specific goals and objectives. The supporters of this theory [8] argue that the firm consists of an internal and external coalition that emanates from the social exchanges that are formed to enhance and control behavior.

The external environment consists of scarce and valued resources that are key for organizational survival. This is because of the uncertainty involved in the external environment in resource acquisition. The relevance of this theory is that the FMCG operating environment is dynamic; risks and uncertainties characterize due to changes in the external environment. This necessitates adopting strategies to counter challenges in the external environment. According to [3], organizations aim to achieve two key objectives: control over resources to reduce dependence on other firms and gain control over resources that enhance the dependence of other firms on themselves. In this regard, the organization can align all its resources to gain a competitive advantage through effective and reliable service delivery.

\section{Customer Service}

Customer service defines the actions of an organization in establishing the customers' needs and tailoring the organization's initiatives to deliberately address the identified needs of the customers satisfactorily and profitably [14]. It was the view by [14] that the notion that customer service was all about ensuring that the organization generates sales and recognizes sales revenue was misguided if the spirit behind making sales was outside the prism of meeting the customers' needs. In this regard, the customers' needs are the foundations of service delivery as they are deterministic of what precisely the organization needs to do and how exactly it will do it as expected by the customers [14].

According to [15], customer service is the provision of services to the organization's clients in the period leading up to the service's sale, during the sale, and after the sale of a service. In the context of this definition, [15] argues that customer service is that which an organization does in the form of such acts as giving customers due to attention, providing responses to questions, providing the customers with as much information as is necessary about the services they are interested in and offering service support post the sale of a service to the customers. This entails that customer service is not only defined narrowly by the acts that are done in the transactional offering of service in exchange for revenue but rather, meeting the needs of the customers before the intention to buy the services is made to such a time that is beyond the sale of the service to the customer [15].

A Study [16] defines customer service as the acts of an organization and all the initiatives that an organization engages in with a view to anticipate, meet and satisfy the needs of their customers. This entails that customer service is an intimate process through which the organization can understand what their customer wants, how they want it, how much of it they want, and how often they want it [16]. Having understood the customers' needs, the organization then deliberately offers to the customers exactly what they want in response to their needs in the manner that they wish to satisfy the needs and expectations of the customers. This translates that customer service is relational and not entirely transactional because it is only when the customers' needs are met that the service provider can begin to realize growth in revenue as a by-product, meeting the customers at their point of appetite [16]. 


\section{Customer Experience}

Customer experience refers to the outcome of the interactions between the organization, the customer, and the services offered by the organizations and the value created as a result of such interactions and the customer purchase behavior [17]. This means that customer experience defines the outcome from the rational, sensory, emotional, physical, and spiritual interactions between the organization and its customers. The customers can have an indepth appreciation and experience of the value each of their transactional relationships with the organization brings [18].

[19] Each time a customer receives services from an organization o interacts with any agent representing the organization; they have the propensity to assess what they expected to come out of the interaction and what they realized from the exchange. In line with this view, [19] defines customer experience as the difference between what the customers are expected to experience and what they perceive to have actualized from their interactions with their service providers. Similarly, [20] argues that customer experience is an expression of the outcome of the interactions between the organization, their services, and their customers as assessed through the net effect of customers' expectations and perceptions. In the same manner, [21] mapped an illustration as a way to define the concept of customer experience, and this is shown in Figure 1 below:

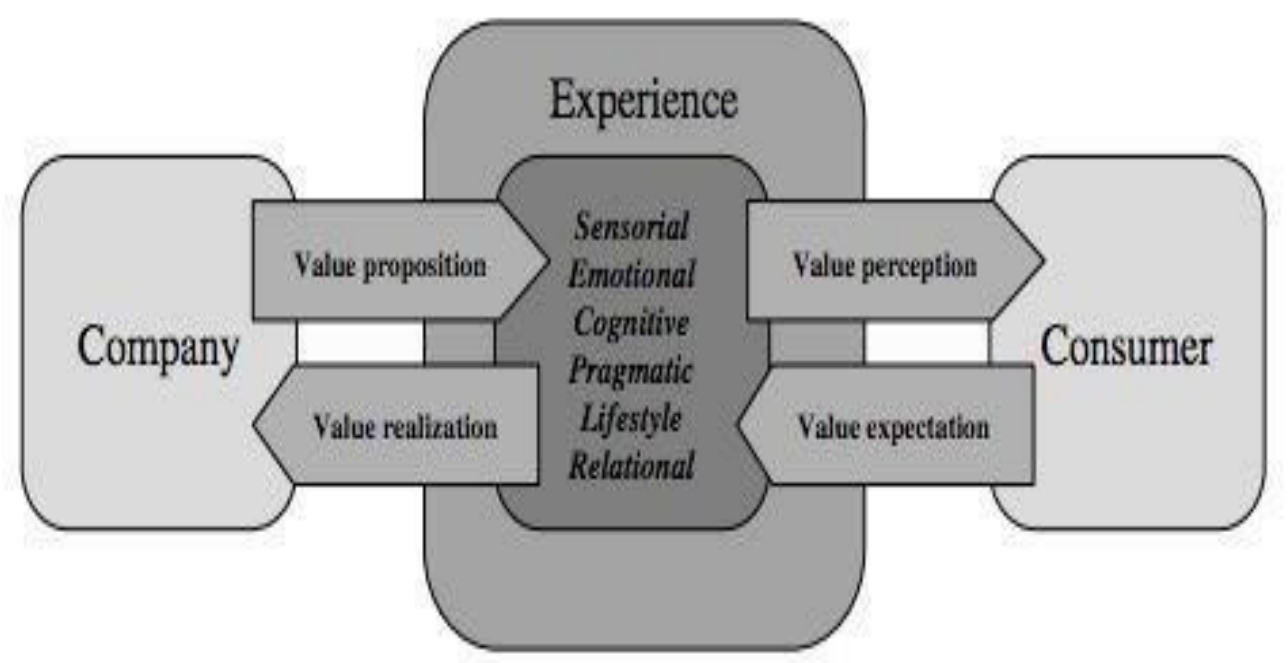

Figure 1. Illustration of Customer Experience

Source: Miller, L. E, Handling nonresponse issues' (2016)

As shown in Figure 1, customer experience is an expression of the difference between the organization's value proposition to the customers and the value perception of the customers from the services that the organization renders to the customers [21]. What this means is that when an organization makes a promise to the customer of the value that the services rendered by the organization will deliver to the customer, customer experience is an expression of the assessment of the value proposition as measured against the perceived value received by the customers [22].

As further illustrated in Figure 1, customer experience is expressed in terms of value expectation and value realization. In this regard, [21] defines customer experience as being the net between the value expectation of the customer and the value that they realize. This definition of customer experience is again an expression of the difference between the value that the customer expects to learn and the value that they recognize. In line with this argument, 
where the value realized by the customer is higher than the value expectation, this translates to a positive customer experience; if the expectation is higher than the value realization, the customer experience is said to be negative in that instance [21].

The overarching objective of any organization that desires to attract new customers and retain them is to give their customers a significantly positive customer experience [23]. To achieve this, the organization must strategically initiate processes to ensure that the customers' expectations are exceeded at each of their interactions with the organization, its services, and its employees [13].

\section{Customer Satisfaction}

A Study [24] defined customer satisfaction as a general evaluation based on the purchase and consumption experience of the good or service over time. [25] Added that customer satisfaction is a function of marketing that establishes the extent to which the organization and its facilities were able to meet the expectations of their customers.

As averred by [24], the access to actionable information by the organization on what the customers expect and how to deliver it to them to meet their expectations is a must when it comes to customer satisfaction. According to [26], customer satisfaction is the psychological state derived from the confirmation or disconfirmation of customer expectations as measured against the customers' feelings ensuant to an actual service experience. It was, therefore, the contention of [26] that customer satisfaction is the judgmental attitude that is subject to specific service consumption. Similarly, it was noted by [27] that customer satisfaction describes affectionate and cognitive responses to actual service encounters by consumers of a particular service.

It is also noted [27] that the cognitive aspect espoused in customer satisfaction defines the customer's own evaluation of the adequacy of the perceived performance in contrast to the customer's expectation standards. On the other hand, the affectionate aspect of satisfaction describes the emotional elements born out of the actual service experience, such as happiness, disappointment, and surprise [26].

Customer satisfaction is the resultant attitude arising from the comparative assessment of the performance of the service providers and the perceived quality expectations in terms of the fulfillment of the customers' desires, goals, and needs [28]. This contrasts with the view of [11], who argued that customer satisfaction is an unobservable, transaction-specific latent variable. Similarly, [29] argued that customer satisfaction represents the experiences, reactions, and emotions of a customer ensuant to the service delivery by their service provider. [30] Postulated that customer satisfaction is the voice of the customers appraising the extent to which the services of their service providers meet or exceed their prior expectations.

\section{Service Delivery and Customer Experience}

According to [31], at the center of customer experience management is to ensure that the organization captures and delivers on the needs and expectations of customers' preservice delivery, during service delivery, and postservice delivery. In this regard, the level of knowledge management at play influences the quality-of-service delivery in terms of how the organization responds to the needs and exceeds the customers' expectations in their diversity [22]. This means that service delivery is the moment of truth, where the customers will experience the degree to which the organization was willing and capable of meeting their needs [32].

Through service delivery, the retailers were able to deliver on their promises to their customers in a manner that conforms or discomforts to the customer's expectations and ultimately influences the experience of the customers in a significant manner [33]. This 
means that service delivery allows the organization to give of itself in the expectation of satisfying the customers' needs, and if the customers experience precisely what they expected, such will be a positive customer experience. If they do not share what they expected, such will amount to a negative customer experience [34]. Therefore, this means that the quality-of-service delivery impacts the degree to which the organization meets the needs of the customers, which in turn impacts the manner of customer experience that the customers have with each interaction with the retailer [33].

In the same manner, [35] argues that customer experience is a function of the extent to which the services offered by the organization address the needs and expectations of the customers. It is in this context that retailers in the FMCG sector rely on the feedback that they receive from their customers to be able to know exactly what the customers expect of them, how the customers feel about their current service offering and as such, determination of how these can be modified and improved to improve the customer experience through superior service delivery [35]. In this regard, service service delivery is both an anticipatory, proactive, and response sets of actions instituted modifying the customer experience, which will impact customer satisfaction [36].

\section{Methodology}

This study was grounded on the positivist research stance, and to this end, the study adopted and followed after the positivism research philosophy. According to [37], the positivist research philosophy places its reliance on the collection and analysis of statistical data. This means that the positivist research philosophy is quantitative and deductive, which translates that the researcher first states the research hypothesis that the research seeks to test. Upon the collection of quantitative data, the researcher statistically tests the hypothesis to confirm or reject the hypothesis [38]. Therefore, the research design adopted in this study was quantitative. The researcher administered a structured survey questionnaire that allowed the respondents to rank their responses on a Likert scale.

The responses were processed quantitatively using the Statistical package for social sciences. The study used convenience sampling to extract a sample of 750 respondents. The application of convenience sampling was based on the fact the researcher approached the respondents who were walk-in customers into retail outlets in Gaborone. In this regard, only such customers who were available and willing to complete the questionnaires at the time of data collection were selected into the sample.

Data was analyzed by way of descriptive statistical analysis as well as inferential statistical analysis. The questionnaire data was processed using SPSS, wherein the study utilized descriptive statistics in the form of mean, standard deviation, and standard error of mean. The mean was used as a measure to determine the general sentiment of the respondents as gauged against the Likert scale utilized for each question presented to the respondents. The standard deviation represented the degree to which the opinions of the respondents differed within each group of respondents.

Multiple linear regression analysis techniques was used in this study in order to make a determination of the nature as well as the strength of the relationship between service delivery and Customer Experience. The regression model that was adopted for this study is given below:

$$
\begin{aligned}
Y=\propto+\beta_{1} G+ & \beta_{2} A+\beta_{3} Q+\beta_{4} D+\beta_{5} P \\
& +\beta_{6} R+\beta_{7} L+\beta_{8} D A+\beta_{9} C E \\
& +\mu \ldots \ldots \ldots \ldots \text { Equation } 1
\end{aligned}
$$

$\mathbf{Y}=$ Customer satisfaction

$\mathbf{G}=$ Gender

$\mathbf{A}=$ Age

$\mathbf{Q}=$ Quality

$\mathbf{D}=$ Diversity 


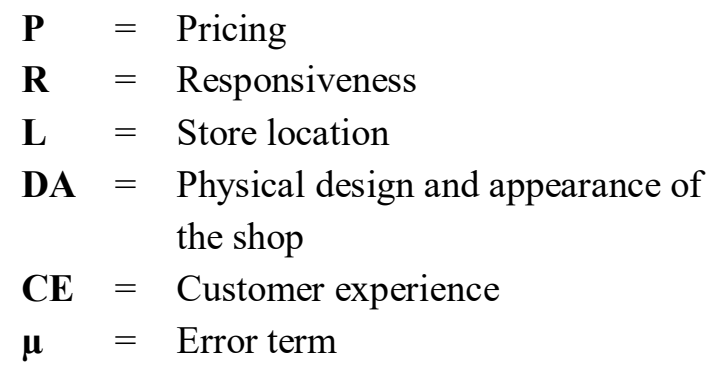

\section{Results and Discussion}

\section{Respondents' Profile}

The study sample comprised of 750 individuals and out of these, 53.6\% $(\mathrm{n}=$ $402 / 750)$ were female and $46.4 \%(n=348 / 750)$ were male. In the same sample, $5.6 \%(\mathrm{n}=$ $42 / 750)$ were below the age of $20 ; 43.9 \%(\mathrm{n}=$ $329 / 750)$ were aged between 20 and 29; 30.1\% $(\mathrm{n}=226 / 750)$ between 30 and 39 years of age; $18 \%(n=135 / 750)$ were aged between 40 and 49 years and $2.4 \%(n=18 / 750)$ were between 50 and 59 years of age.

\section{Level of Customer Satisfaction}

Table 1 shows the descriptive statistics on the rating ascribed to the various factors of customer satisfaction and the overall level of customer satisfaction in the Retail sector of Botswana.

Table 1. Descriptive on Factors of CS, CE, and CS

\begin{tabular}{|l|l|l|l|l|l|l|l|l|}
\hline & Q & D & P & R & L & DA & CE & CS \\
\hline Mean & 3.70 & 4.25 & 3.09 & 3.11 & 3.97 & 4.00 & 4.16 & 3.87 \\
\hline SD & 1.234 & 1.152 & 1.081 & 1.268 & 1.310 & 1.217 & 1.327 & .944 \\
\hline N & 750 & 750 & 750 & 750 & 750 & 750 & 750 & 750 \\
\hline
\end{tabular}

The findings in Table 1 show that in general terms, the quality of products within the FMCG food and groceries sector of Botswana were ranked as being good (mean $=3.70$ ), and from this finding, it can be deduced that the customers found the quality of products that they consumed to be commendably good and as such, worth consumption. Product diversity ranked good (4.25), which in essence means that the customers were satisfied by the level of diversity that their retailers offered and the latitude this afforded them in terms of choice. The pricing of products within the retail sector of Botswana was found to be fair (mean = 3.09), and this means that the customers were of the opinion that these products were not too cheap and, at the same time, not exorbitantly priced and out of their financial reach.

The level of responsiveness within the retail sector of Botswana was ranked as being moderate $($ mean $=3.11)$. This means that the employees within the retail sector attended to the needs of the respondents with average speed and moderate attentiveness. The location of the retail outlets was ranked as being well placed (mean = 3.97). This means that the customers were of the view that the retail outlets were in close proximity to where they resided and, as such, we're very accessible to them. The design and appearance of the retail shops in the FMCG food and groceries sector were ranked as being good $($ mean $=4.00)$. This means that the shops' appearance was viewed as appealing, and the arrangement of shelves was convenient for ease of movement and for customers' comfort to locate the goods they wanted to purchase from the shops. In terms of customer experience, the findings in Table 1 show that the customers ranked their customer experience within the retail sector as being good (mean $=4.16)$. This means that, in general terms, the customers who took part in the survey were of the view that the retailers met their expectations to a great extent, and this, in turn, gave them a good customer experience in the main. The researcher sought to determine customer satisfaction with the FMCG food and groceries sector of Botswana. The survey allowed the customers to provide a personal rating of their satisfaction at the individual level.

The findings were compounded, and as per Table 1, the level of customer satisfaction in 
Botswana's FCMG sector was found to be good (mean $=3.87$ ). This means that, in general terms, the customers were satisfied with the service that they were offered by their choice retailers. While the level of satisfaction differed at the individual level, the overall satisfaction was ranked as being good.

\section{Correlation Between Factors of CS, CE, and $\mathrm{CS}$}

To examine the manner of correlation between the factors of customer satisfaction, customer experience, and customer satisfaction, the study undertook and correlation analysis, and the findings in this regard are given in Table 2.

Table 2. Results from the Correlation Analysis

\begin{tabular}{|l|l|l|l|l|l|l|l|l|}
\hline & $\mathbf{Q}$ & $\mathbf{D}$ & $\mathbf{P}$ & $\mathbf{R}$ & $\mathbf{L}$ & $\mathbf{D A}$ & $\mathbf{C E}$ & $\mathbf{C S}$ \\
\hline $\mathbf{C E}$ & $.740^{* *}$ & $.624^{* *}$ & $-.662^{* *}$ & $.627^{* *}$ & $.757^{* *}$ & $.687^{* *}$ & 1 & $.638^{* *}$ \\
\hline $\mathbf{C S}$ & $.533^{* *}$ & $.714^{* *}$ & $-.848^{* *}$ & $.526^{* *}$ & $.203^{* *}$ & $.153^{* *}$ & $.638^{* *}$ & 1 \\
\hline
\end{tabular}

Table 2 shows that the quality of products had a strong positive correlational relationship with both customer experience $(\mathrm{r}=0.740)$ and customer satisfaction $(\mathrm{r}=0.533)$. This means that customer experience and customer satisfaction were directly proportional to the quality of products being sold within the sector. The higher the quality of products, the greater the customer experience, and satisfaction level. These findings concur with [33], who argued that the quality of goods in the retail sector has a strong positive correlational relationship with both customer experience and customer satisfaction.

Similarly, the study found that there existed a strong positive correlation between product diversity and both customer experience $(r=$ $0.624)$ and customer satisfaction $(r=0.714)$. From this finding, it can be deduced that, the more diverse the product range on offer in the retail sector, the greater the level of customer experience and the better the level of customer satisfaction. These findings agree with [35], who also argued that the level of customer experience and customer experience were positively correlated with product diversity within the retail sector.

Pricing of the products was found to have a strong negative correlation with customer experience $(\mathrm{r}=-0.662)$ and customer satisfaction $(\mathrm{r}=-0.848)$. This means that, as the product's price increases, the customer experience declines. Conversely, the lower the price, the more positive the customer experience becomes and the higher the level of customer satisfaction. This could be attributed to the fact that the customers in Botswana's retail sector are price sensitive. As such, their experience and satisfaction are positive where their perception of pricing was favourable. The findings, therefore, agree with [24], who argued that due to price sensitivity amongst the customers in the retail sector, pricing shares a strong negative correlational relationship with the customer experience and customer satisfaction.

The level of responsiveness has a strong positive correlation with customer experience $(\mathrm{r}$ $=0.627)$ and with customer satisfaction $(\mathrm{r}=$ $0.526)$. This could be attributed to the fact that the more responsive the organization is to the customers' needs and the more the employees within the retail sector attend to the customers' needs, the greater the customer experience and ultimately, the greater the level of customer satisfaction. These findings concur with [35], who opined that as the level of responsiveness shown by the organization increases, so does the customer experience and customer satisfaction. Location was found also to have a solid positive correlational relation $(\mathrm{r}=0.757)$ with customer experience but a weak positive correlation $(r=$ 0.203 ) with customer satisfaction. This could be attributed to the fact that the proximity of the retail outlets to the customer impacts how the customers experience service delivery. The more accessible the outlets are, the greater the level of 
customer experience. Still, however, it doesn't follow that the more accessible the outlets are that the customer satisfaction will be significantly high [31].

The design and appearance of the retail shops were found to have a strong positive correlation $(r=0.687)$ with the customer experience and a weak positive correlation $(\mathrm{r}=0.153)$ with customer satisfaction. Design and appearance also have a bearing on the ease with which customers can navigate in the retail outlets, and as such, the more the design allows for navigation. It makes it easy to locate the goods the customers want to buy, the greater the customer experience and customer satisfaction [16].

\section{Correlation Between CE and CS}

The study further sought to determine the nature and strength of the correlational relationship between customer experience and customer satisfaction. From the findings of the correlation analysis given in Table 2 , it can be deduced that customer experience has a solid positive correlational relationship with customer satisfaction $(\mathrm{r}=0.638)$. This could be attributed to the fact that both customer experience and customer satisfaction related to the trade-off between customer perceptions of service and the perception of service received. In this regard, where the customer experience is positive, it also follows that customer satisfaction will be high. These findings concur with [13, 32, 34], all of whom argued that there existed a strong positive correlational relationship between customer experience and customer satisfaction.

\section{Impact of Factors of Customer Satisfaction on Customer Satisfaction}

To determine the impact of the various factors of customer satisfaction on customer satisfaction, the multiple regression analysis was undertaken at a $5 \%$ level of significance, The findings in this regard are given in Table 3.

Table 3. Summarised Results from the Regression Model

\begin{tabular}{|l|l|l|l|}
\hline Independent Variables & $\boldsymbol{\beta}$ & $\mathbf{t}$ & Sig. \\
\hline (Constant) & 1.804 & 13.989 & .000 \\
\hline Gender & .345 & 13.462 & .000 \\
\hline Age & -.015 & -.582 & .561 \\
\hline Product Quality & .417 & 9.721 & .000 \\
\hline Product Diversity & .300 & 8.746 & .000 \\
\hline Pricing & .303 & 7.676 & .000 \\
\hline Responsiveness & .417 & 10.528 & .000 \\
\hline Store Location & .081 & 1.397 & .163 \\
\hline Design and Appearance & .338 & 8.164 & .000 \\
\hline Customer Experience & .088 & 2.314 & .021 \\
\hline $\mathrm{R}^{2}=0.662$ & & \\
\hline Adj. $\mathrm{R}^{2}=0.658$ & \multicolumn{5}{|l}{} \\
\hline F $=160.886$ & \multicolumn{5}{|l}{} \\
\hline Sig. $=0.000$
\end{tabular}

The findings in Table 3 show that the Rsquare coefficient for the regression model was 0.658 , and this means that when all independent variables are taken as a unit has, they have a $65.8 \%$ explanatory power over the variations in the level of customer satisfaction in the retail sector of Botswana. The findings further show the $\mathrm{F}$-value $=160.886$ and $\mathrm{p}$-value $=0.000<0.05$, and this further indicates that the regression model used in this study was statistically significant and capable of explaining the variations at the back of changes in the independent variables. In line with the 
summarised regression model results in Table 3, the following regression equation emerged:

$$
\begin{aligned}
Y=1.804+ & 0.345 G+0.417 Q+0.300 D \\
& +0.303 P+0.417 R \\
& +0.338 D A+0.088 C E+\mu
\end{aligned}
$$

As per the findings in Table 3, it can be deduced that the gender of the customers was positively correlated $(\beta=0.345)$ to customer satisfaction. In this regard, from the Beta coefficient, it can be deduced that a unit increase in gender dynamics in the population of customers will increase the level of customer satisfaction by a factor of 0.345 . In the same manner, the $\mathrm{p}$-value $=0.000<0.05$ shows that gender had a statistically significant impact on customer satisfaction, and therefore, the hypothesis that gender has a statistically significant effect on customer satisfaction is accepted by this study. This finding agrees with [36], who argued that gender significantly impacts customer satisfaction. The findings also show that gender was negatively correlated to customer satisfaction within the retail sector of Botswana $(\beta=-0.015)$ and the $p$-value $=$ $0.561>0.05$. This means that even though age had a negative impact on customer satisfaction, the impact was not statistically significant. Therefore, the study accepts the null hypothesis, which stated that age does not have a statistically significant impact on customer satisfaction. This finding is inconsistent with the claim by [31] that the age of customers has a statistically significant impact on customer satisfaction in the retail sector.

Product quality was fund to have a positive impact on customer satisfaction $(\beta=0.417)$, $p$ value $=0.000<0.05$. In this regard, it can be deduced that a unit increase in the product quality offered by retailers will increase the level of customer satisfaction by factor of 0.417 . The $\mathrm{p}$-value $=0.000<0.05$ shows that product quality has a statistically significant impact on customer satisfaction. In this regard, the study accepts the alternative hypothesis that product quality has a statistically significant impact on customer satisfaction. This is consistent with the argument by [8] that product quality has a statistically significant impact on customer satisfaction.

The findings show that product diversity has a positive and statistically significant impact on customer satisfaction within the retail sector of Botswana $(\beta=0.300), p=0.000<0.05$. Therefore, the study accepts the alternative hypothesis, which stated that product quality has a statistically significant impact on customer satisfaction. This finding agrees with [3] who argued that diversity of products in the retail sector has a statistically significant effect on level of customer satisfaction. Pricing was found to have a positive and statistically significant impact on customer satisfaction $(\beta=0.303), p=$ $0.000<0.05$. In this regard, the study accepts the alternative hypothesis that the pricing of products has a positive and statistically significant impact on the level of customer satisfaction in the retail sector. This finding concurs with [8] who argued that pricing has a statistically significant effect on customer satisfaction in the retail sector.

Responsiveness was found to have a positive and statistically significant impact on customer satisfaction $(\beta=0.417), p=0.000<0.05$. In this context, the alternative hypothesis that responsiveness has a statistically significant impact on customer satisfaction is accepted by this study. This finding also concurs with [14] who argued that level of the level of responsiveness in the retail sector has a positive and statistically significant impact on the level of customer satisfaction. The study found that store location did not have a statistically significant effect on customer satisfaction in the retail sector of Botswana $(\beta=0.081), p=0.163>0.05$. The study, therefore, accepts the null hypothesis, which stated that store location does not have a statistically significant impact on customer satisfaction. This finding does not agree with [2], who opined that the location of the retail outlets had a statistically significant effect on the level of customer satisfaction in the retail sector. The design and appearance of the store had a positive 
and statistically significant impact on the level of customer satisfaction in the retail sector $(\beta=$ $0.338), p=0.000<0.05$. Based on these findings, the study accepted the alternative hypothesis that the design and appearance of the store have a positive and statistically significant impact on customer satisfaction. This is consistent with [5], who also argued that the design and appearance of the retail outlet had a significant effect on the level of customer satisfaction.

The study found that customer experience positively and statistically significant impact on customer satisfaction in Botswana's retail sector $(\beta=0.088), p=0.021<0.05)$. Ensuant to this finding, the study accepted the alternative hypothesis, which stated that customer experience has a statistically significant impact on customer satisfaction. This finding concurs with [35], who argued that customer experience positively and statistically significant impact on customer satisfaction.

\section{Summary and Conclusion}

The study sought to determine the level of customer satisfaction within Botswana's retail sector, and in this regard, the focus was placed on the FMCG food and groceries sector. In determining the level of customer satisfaction, the study sought also to determine how the various factors of customer satisfaction were correlated to and impacted customer satisfaction. The study thus found that an overall customer satisfaction score of 3.87 was attached to the level of customer satisfaction in Botswana. This means that the study found that the level of customer satisfaction was good on a 5-point scale $(1=$ very poor and $5=$ Excellent $)$. The study found that with the exception of pricing which has a negative correlation with customer satisfaction, all other factors of customer satisfaction considered in this study displayed a positive correlational relationship with customer satisfaction. The study used multiple regression analysis to determine the impact of various factors of customer satisfaction on customer satisfaction and the regression model was statistically significant was found to predict $65.8 \%$ changes in customer satisfaction. In overall terms, the study found that gender, product quality, product diversity, pricing, responsiveness, design and appearance and customer experience all had a statistically significant impact on customer satisfaction in Botswana.

The implication of these findings is that, whilst there are a number of factors that are regarded to have a bearing on level of customer experience in the retail sector, management within Botswana's FMCG food and groceries sector should pay particular attention to gender, product quality, product diversity, pricing, responsiveness, design and appearance and customer experience. In this regard, it is recommended that in their service delivery, they should be gender sensitive given the fact that gender impacts significantly on the level of customer satisfaction. On the other hand, the study recommends that management within the sector should adopt a quality and diversitycentric policy within their outlets. Where the organizations are quality-centric and diversitycentric, they will provide superior quality of products and services and will also offer significant product diversity to cater to the diverse tastes and needs of their customers.

In the same manner, the study recommends that the retailers should employ customerfocused employees who understand the value of customers and will be responsive to the needs of the customers. The pricing models that are adopted within the sector should, whilst seeking to attain organizational profitability should also consider affordability of products amongst the customers. To achieve competitive pricing, the retail sector should strengthen supply chain management so as to manage costs on the supply chain for the benefit of customers. The study also recommends robust customer experience management practices which are anchored on robust customer knowledge management practices where every encounter with the customers and ever complaint laid by the 
customers should serve as a key source of information on how the service delivery can be enhanced and ultimately customer experience enhanced.

\section{Acknowledgements}

I would like to express my sincere gratitude for the help I received from my supervisor, Dr. Lesego Selotlegeng, whose guidance, expertise, and patience were of great value. I would also like to acknowledge the Government of Botswana and my employer: the Department of Public Service Management (DPSM), for the support they gave to carry out this research

\section{References}

[1] Berry, L. (2017) Discovering the Soul of Service: The Nine Drivers of Sustainable Business Success. New York, USA: The Free Press.

[2] Mukherjee, A.., Nath, P., and Pal, M. (2018) 'Resource, service quality and performance trade: a framework for measuring efficiency of the retail sector', J. Oper. Res. Soc.., 54(7), pp. 723-735.

[3] Kitapci, O. et al. (2018) 'The paths from service quality dimensions to customer loyalty: An application on supermarket customers', Management Research Review, 36(3), pp. 239 - 255.

[4] Price, L.., Arnould, E. and Tierney, P. (2018) 'Going to Extremes: Managing Service Encounters and Assessing Provider Performance', Journal of Marketing, 59(7), pp. 83-9.

[5] Czepiel, J. A. (2016) 'Service Encounters and Service Relationships: Implications for Research.', Journal of Business Research, 31(3), pp. 13-21.

[6] Khan, S. and Akhter, W. (2017) 'Service quality and the moderating effect of Shari'ah perception on client satisfaction: A comparison of islamic and conventional microfinance in Pakistan', Cogent Economics and Finance. Doi: 10.1080/23322039.2017.1315206.

[7] Sharif, M. et al. (2017) 'The Effect of Service Quality and Government Role on Customer.

[8] Satisfaction: Empirical Evidence of Microfinance in Kenya', International Journal of Business and Social Science. fellow workmates, and classmates' efforts and willingness to share ideas, which made this project possible. I would also appreciate Texila American Mentors who really believed in me and gave me the chance to work with me through out. Last but not least, I would also like to acknowledge the unquantifiable moral support from my family and friends without which it would have been impossible to complete this Journal.

\section{Conflict of Interest}

The author declares that there is no conflict to be included in the journal.

[9] Madan, M. and Kumari, P. (2012) 'Determinants of customer satisfaction: A study of organised retail outlets in Delhi', Delhi Business Review, 13(1), pp. 117-126.

[10] Moriarty, M. et al. (2014) The 2014 African

Development Index - Seizing Africa's Retail

Opportunities. Available at: http://www.atkearney.com/documents/10192/43719 60/Seizing+Africas+Retail+Opportunities\%0Apdf/7 30ba912-da69-4e09-9b5d-69b063a3f139.

[11] Central Statistics Office (2018) Informal Sector Survey Report. Gaborone.

[12]Barney, J. (2018) 'Firm resources and sustained competitive advantage', Journal of Management, 17(4), pp. 99-120.

[13]Prehalad, C. and Hamel, G. (2017) 'The Core Competence of the Corporation', Harvard Business Review, 68(3), pp. 79-91.

[14] Cho, T. and Hambrick, D. (2016a) 'Attention as the Mediator Between Top Management Team Characteristics and Strategic Change: The Case of Airline Deregulation.', Organizational Science, 17(4), pp. 453-469.

[15]Cook, S. (2016) Measuring Customer Service Effectiveness. Vermont: Gower Publishing, Ltd.

[16]Oliver, R. L. (2018) 'Whence consumer loyalty?', Journal of Marketing, 63(4), pp. 33-44.

[17] Pollack, B. L. (2018) 'The Nature of the Service Quality and Satisfaction Relationship Empirical 
Evidence for the Existence of Satisfiers and Dissatisfiers.', Managing Service Quality, 18(6). [18] Valenzuela, L. et al. (2014) 'Salesperson CLV Orientation's Effect on Performance', Journal of Business Research, 64(4), pp. 550-557.

[19] Martínez-Ruiz, M.., Jiménez-Zarco, I. and Cascio, R. (2017) 'Customer satisfaction's key factors in Spanish grocery stores: Evidence from hypermarkets and supermarkets', Journal of Retailing and Consumer Services, 17(4), pp. 278 285.

[20] Akram, K. et al. (2016) 'Role of knowledge management to bring innovation: An Integrated approach.', International journal of Marketing, 5(4), pp. 268-280.

[21] Miller, L. E. and Smith, K. L. (2016) 'Handling nonresponse issues', Journal of Extension, 16(1), pp. 45-50.

[22] Mahr, D. and Lievens, A. (2015) 'Virtual Lead Users Communities: Drivers of Knowledge Creation for Innovation', Research Policy, 41(2), pp. 167-177. [23] Bhatti, K. K., and Qureshi, T. M. (2017) 'Impact of employee participation on job satisfaction, employee commitment and employee productivity, International Review of Business Research Papers, 33(6), pp. 54-68.

[24]Busacca, B.., Cillo, P. and Mazursky, D. (2016) 'From Market Research to Creativity Templates: Leveraging Tacit Knowledge for Ideation', in Tollin, K. and Caru, A. A. (eds) Strategic Market Creation. Chichester: John Wiley \& Sons, Ltd, pp. 3-26.

[25]Randhawa, K. and Scerri, M. (2015) Service innovation: A literature review. In The handbook of service innovation. London, United Kingdom: Springer.

[26]Chandi, A.., Richard, C., and Eugine, T. (2017) 'Service Innovation Capabilities towards Business Performances in the Hotel Sector of Zimbabwe.', African Journal of Hospitality, 7(2), pp. 1-17.

[27] Gulati, R. and Higgins, M. C. (2015) 'Which ties matter when? The contingent effects of interorganizational partnerships on hotel sector success Rwanda.', Strategic Management Journal, 24(1), pp. 127-144.

[28] Kamoche, K. and Cunha, M. (2016) 'Minimal structures: from jazz improvisation to product innovation,' Organization Studies, 22(5), pp. 733764.

[29] Inkpen, A. C. (2017) 'Learning through joint ventures: A framework of knowledge acquisition,' Journal of Management Studies, 37(1), pp. 10191043.

[30]Keiningham, T. (2001) The customer delight principle: Exceeding customers' expectations for bottom-line success. Chicago: McGraw-Hill.

[31]Black, J., and Kase, H. (2016) 'Inter-agency cooperation in the hospitality sector, Hospitality Service Review, 37(2), pp. 26-32.

[32]Nasution, R. et al. (2014) 'The Customer Experience Framework as Baseline for Strategy and Implementation in Services Marketing,' Procedia Social and Behavioral Sciences, 148(7), pp. 254-261. DOI: https://doi.org/10.1016/j.sbspro.2014.07.041.

[33] Chawla, D. and Joshi, H. (2019) 'Customer experience management practices in Indian industries-A comparative study, Journal of Knowledge Management, 16(4), pp. 708-725.

[34]Chen, T. and Huang, H. (2017) 'An Integrated CKVC Model to Building Customer Experience Management Synergy and Impact on Business Performance. Trade and Development, International Journal on Economics, 17(7), pp. 78-82.

[35] Mafabi, S.., Munene, J. and Ntayi, J. (2017) 'Service delivery, customer experience, and organisational resilience: Organisational innovation as a mediator in Uganda Retail Sector', Journal of Strategy and Management, 5(2), pp. 57- 80.

[36] Salojarvi, H. (2019) 'Determinants of Customer Satisfaction in the FMCG sector', in Anzmac Conference. Melbourne-Australia, pp. 16-22.

[37] Sull, D. (2015) 'Strategy as Active Waiting', Harvard Business Review, 83(9), pp. 120- 129.

[38] Igwenagu, C. (2016) 'Fundamentals of Research Methodology and Data Collection', LAP Lambert Academic Publishing.

[39] Kothari, C. (2017) Research methodology: methods and techniques, New Age International. doi: http://196.29.172.66:8080/jspui/bitstream/12345678 9/2574/1/Research\%20Methodology.Pdf. 


\title{
The Impact of Social Media on $21^{\text {st }}$ Century Businesses Growth: A Case Study - Background Check International Limited, Nigeria
}

\author{
Alexander Kolawole Olugbodi \\ MBA in International Business, Texila American University, Nigeria
}

\begin{abstract}
The advent of the internet and advancement in technology has changed the way businesses are done across the world. This advancement in technology has also resulted in the development of numerous social media platforms. With more than 4.48 billion social media users worldwide in July 2021, individuals, small businesses, and even large corporations now rely heavily on social media to promote various businesses, outsmart competitors, and grow their businesses. This study aimed to examine the impact of social media on business growth in this century and to examine to what extent social media platforms have revolutionized and transformed how businesses now market their products and services, and also to affirm the impact of these social media marketing activities on the organizations business growth. I used Background Check International Limited, Nigeria, the company wherein I am a Chief Executive Officer, as the case study for the influence of social media marketing on businesses. The study found that the impact of social media platforms on business growth is significant. Using my company as a case study, social media marketing has proven to be a better alternative to traditional marketing in all ramifications. Social media has successfully reduced the world to a small global village, enabling tremendous business growth. I also found, beyond all reasonable doubt, that social media will continue to disrupt any remaining aspect of traditional marketing that may still be surviving till day.
\end{abstract}

Keywords: Businesses, Growth, Social media.

\section{Introduction}

The advent of the internet and advancement in technology has changed the way businesses are done across the world [1]. For instance, in the banking industry some 25 years ago, the banking system was a combination of both manual banking and analog computing which were primarily used for transactional event capturing $[2,3]$. However, the growth in internet connectivity and technologies has revolutionized the banking industry across the globe. It is now the era of online and real-time banking and automated teller machines [4].

The internet made possible a very sharp revolution in the way human beings communicate and share business marketing information across the globe [5]. The initial innovations came with the introduction of electronic mails, which disrupted the way we mail ourselves, whether locally, nationally, or internationally [6]. The email reduced so drastically the volume of physical surface letters that are being pushed all over by post offices.

After electronic mails, there was the introduction of various social media platforms such as Facebook, Twitter, Linked In, Google+, YouTube, and much more. And more recently came WhatsApp, Instagram, Snapchat, Pinterest, and YouTube. Like anything new, the growth of social media was slow and gradual. Everybody was settling down with the email when the social media world took off.

The latest data show that there will be 4.48 billion social media users around the world in July 2021, and these figures are still expected to 
grow as mobile device usage and mobile social networks increasingly gain traction [7]. The advent and massive adoption of these platforms or tools have introduced the social market phenomenon, which is the act of using the various social media platforms as the means of marketing products and services by organizations to prospects [8].

Undoubtedly, social media has totally changed how marketing used to be done before now, and obviously, the change has come to stay. In the book "No Ordinary Disruption" Richard Dobbs reported that Americans spent a record \$2.65 billion online in just one day on December 1, 2014. Meanwhile, on November 11 of the same year, on China's Day, Alibaba, China's biggest e-retailer, recorded sales of more than $\$ 9.3$ billion, a record for a single day anywhere in the world at that time. The leading social networks are usually available in multiple languages and enable users to connect with friends or people across geographical, political, or economic borders.

In this study, I will attempt to answer the hypothesis that social media platforms have revolutionized and transformed how businesses now market their products and services and affirm the impact of these social media marketing activities on the organization's business growth. I will be using Background Check International Limited, Nigeria, the company wherein I am a Chief Executive Officer, as a case study of the influence of social media marketing on businesses.

\section{Literature Review}

A study attested that social media is a channel of communication that can be channeled through blogs, audio conferencing, video conferencing, emails, and many more [9]. These channels require little energy and save time with a bit of cost, yielding results immediately. According to research conducted in the United States, the study found that the creation of virtual customer environments (VCEs) where online communities of interest formed around a specific merchandise, trade name, or firms were made effective through social media which includes LinkedIn, Facebook, Twitter, Instagram [10].

Despite the paradigm shift in the $21^{\text {st }}$ century in using social media, the level of development in Nigeria has negatively affected the business industry. Many firms have played a high level of ignorance in being tech-savvy due to lack of proper understanding in handling digital tools, inability to demonstrate the value of tech solutions, and also the fear of the unknown (fraudulent practices on social media platforms).

Another study stated that social media helps in building up the reputation of firms' sales and survival [11]. It can also aid the development of a firm's worthiness, increase customer and supplier contacts, bring to light where resources and funding are available, promote innovation, and help cultivate strategic partnerships [12].

A study made remarked that the adoption of the Internet could facilitate the increase of its customer and market base, yielding a positive outcome in the growth and development of the business [13]. Irrespective of how accessible or cordial a company is, it must make itself visible by inclusion on the web; otherwise, all efforts made will turn out in futility [14].

These electronic Word of Mouth (eWOM) statements expressed on the web are much prevalent in the business and service industry to help consumers share their point of view [15]. In other to outsmart other strong business contenders, most firms are expected to keep proper track and examine feedback received from customers on their various social media handles in comparison with information acquired on the contenders' site to know the loopholes that should be filled with immediate effect and also helps in decision making [16].

\section{Traditional Marketing}

The initial means of marketing before the advent of any media means of advertising and marketing such as print media, radio, or television was the word. A very colloquial and down-to-earth way of passing information 
around. One disadvantage of the word-of-mouth method of dissemination of information is the distortion of the original information passed across by business owners. Such distortions can either make or mar a business, depending on the margin of error and direction of the misinformation that might have been introduced.

The invention of radio sets could arrest the downside of word of mouth because a business concern would advertise based on scripted messages. So even if there are distortions in the word-of-mouth dissemination of the radio broadcast jingles, the original version would arrest misinformation. Radio advertisements or jingles do not come free. There is always the cost attached to conceptualize the advert and scripting it. The radio stations also charge based on the length of the jingles.

The downside of radio marketing is that prospective buyers would only be left to imagine the advertised products' sizes, shapes, and colors. They only get to encounter the products when they visit the stores to purchase the products. Buyers can either be disappointed because the advert might just have exaggerated the products' look, feel and functions. At the same time, some may be impressed because the product is exactly as it was advertised.

The improvement on the radio means of marketing is the invention of the television set, which added vitality to jingles. Now prospects can see the visual impression of the products being advertised to them. The Television set introduced some element of visual drama to the function and benefits of products and services that businesses are marketing to the general public that constitutes the pool from which I prospect will emanate. Marketing via television set brought along its own cost. The cost of scripting, the cost of models that will act the function and importance of products and services, the cost of making voice-overs, and the cost of broadcasting on a seconds or minutes basis. Television also makes it possible for companies to create documentaries that showcase information on the businesses and customers of organizations. One of the most significant disadvantages of marketing through the TV set is the cost of running an advert on products either on a regional, national, or international basis. Until the advent of cable televisions, advertising products and services globally was an uphill task. Organizations would need to get in touch with television stations across various countries to market the stuff. Different models may be required in different countries to localize their products. There may be some issues with visas and immigration from country to country.

The introduction of marketing through press media and billboards also added advantages to the dissemination and marketing of products. The challenges with this are that not every prospect can afford to buy the newspapers. While some of them may be uneducated. As for billboards, the prospects will only get to see some adverts only if they are passing through the locations where the boards are erected. Due to many levies and unnecessary charges, billboard advertising remains a no-go area for many companies.

\section{Social Media: The Gamer Changers}

The game-changer in the highest method of marketing products and services is the introduction of the various social media platforms, which has transformed the way businesses are now marketed. 


\section{ค(1)

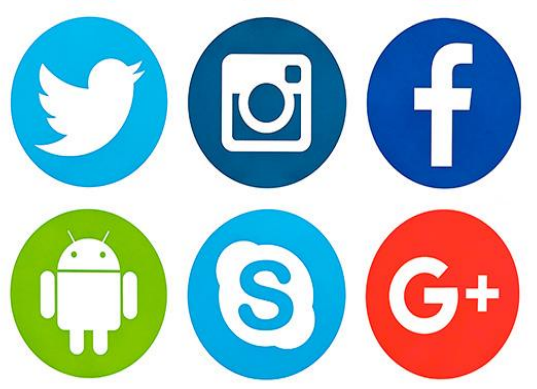

Figure 1. Courtesy of Security Magazine

\section{History of Social Media}

According to the small biz trend website, technology began to change very rapidly in the 20th Century. After the first supercomputers were created in the 1940s, scientists and engineers began developing ways to create networks between those computers, which gave birth to the Internet. CompuServe, which was developed in the 1960s, was the earliest form of the internet. Electronic mails were also created during this time. By the 1980s, home computers were becoming more common, and social media was becoming more sophisticated. Internet relay chats, or IRCs, were first used in 1988 and became famous well into the 1990s. The first recognizable social media site, Six Degrees, was created in 1997. It enabled users to upload a profile and make friends with other users. In 1999, the first blogging sites became popular. Sites like MySpace and LinkedIn gained prominence in the early 2000s, and sites like Photobucket and Flickr facilitated online photo sharing. YouTube came out in 2005, creating an entirely new way for people to communicate and share across great distances.

By 2006, Facebook and Twitter became available to users throughout the world. They are amongst the most popular social networks on the Internet. Other sites like Tumblr, Spotify, Foursquare, and Pinterest began popping up to fill specific social networking niches. Today, there is a tremendous variety of social networking sites, and many of them can be linked to allow cross-posting.

\section{What is Social Media?}

Social media are Web 2.0 Internet-based applications, and users' generated content is the lifeblood of social media. Social media facilitate the development of online social networks by connecting a user's profile with those of other individuals or groups. According to a study, social media has no precise definition and is a two-way street that facilitates effective communication [17]. This definition is in tandem with other studies that defined social media as a medium used to transmit information to a broader audience $[18,19]$.

Merriam-Webster dictionary defined social media as "forms of electronic communication through which people create online communities to share information, ideas, personal messages."

Social media technologies include blogs, business networks, enterprise social networks, microblogs, photo sharing, social bookmarking, social gaming, social networks, video sharing, and virtual worlds.

\section{What is Social Media Marketing?}

Social media marketing uses various social media platforms as the means of marketing products and services by organizations to prospects. Most organizations outsource the management of their social media marketing to 
professionals. In contrast, some organizations now create an entirely stand-alone department that sees to their online and social media marketing activities.

Undoubtedly, social media has totally changed how marketing used to be done before now, and obviously, the change has come to stay. In the book "No Ordinary Disruption" by Richard Dobbs, it was reported that on December 1, 2014, which was the Cyber-Monday in the USA, Americans spent a record $\$ 2.65$ billion online. Just in one day! This was made possible due to the existence of the internet and social media, which were used to create awareness for millions of Americans [21].

Meanwhile, on November 11 of the same year, on China's Day, Alibaba, China's biggest e-tailer, recorded sales of more than $\$ 9.3$ billion, a record for a single day anywhere in the world [22]. For us to have a rough idea of the volume of revenue being generated by the social media platforms, Facebook, on February 19, 2014, acquired WhatsApp for a stunning $\$ 19$ billion [23]. WhatsApp had 450 million users when Facebook bought it.
In 2012 Facebook grew its mobile advertising to $66 \%$ of total advertising revenue in the $3 \mathrm{rd}$ quarter of 2014 [24].

\section{Statistics of Users}

This statistic provides information on the most popular networks worldwide as of July 2018 , ranked by the number of active accounts. Market leader, Facebook was the first social network to surpass 1 billion registered accounts and currently sits at 2.2 billion monthly active users. The sixth-ranked photo-sharing app, Instagram, had 1 billion monthly active accounts.

Pinterest was the fastest independently launched site to reach 10 million unique monthly visitors. Consumers' social network usage is highly diverse: platforms such as Facebook or Google+ are highly focused on exchanges between friends and family. They constantly push interaction through features like photo or status sharing and social games. Other social networks like Tumblr or Twitter are all about rapid communication and are aptly termed microblogs. Some social networks focus on community; others highlight and display usergenerated content.

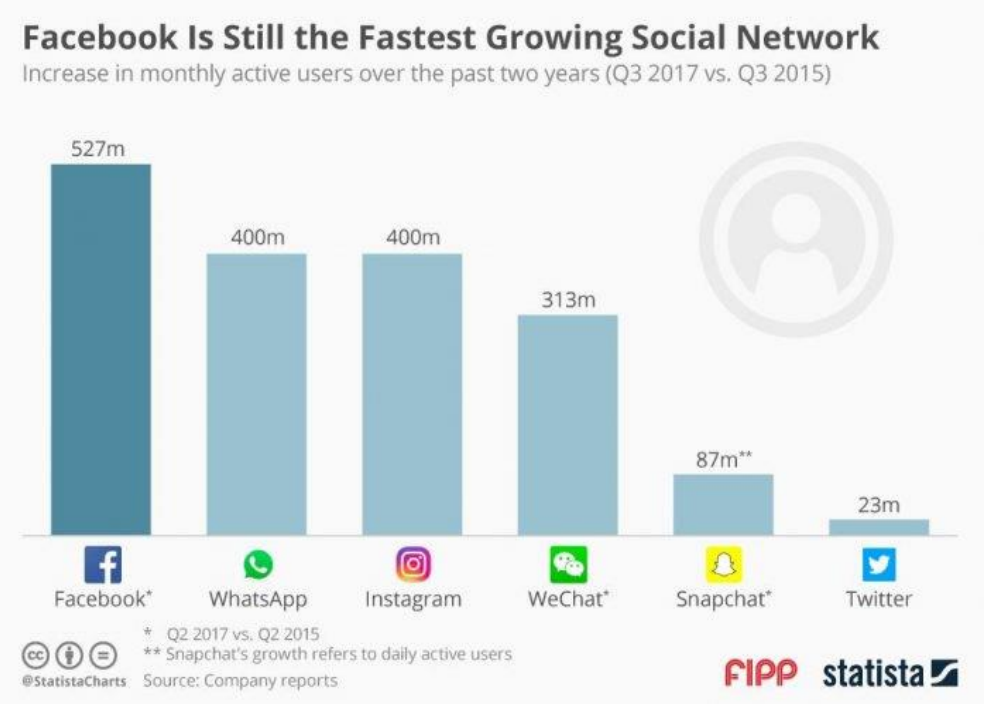

Figure 2. Picture Courtesy of Statista

\section{Methodology}

This study employed a qualitative research methodology. Some key staff of Background
Check International, especially those in top positions, sales, and digital marketing was, interviewed on their thoughts on the impact of 
social media marketing on the activities and financial performances of the company. Their responses are presented in the results section. Similarly, I asked my over 23,000 connections on LinkedIn these questions: "The Role of Social Media in Business Growth" What is your candid response to this? Your input will be appreciated. Their responses were analyzed and also presented in the results section.

To ensure that participants were the best fit for the study, all participants were either fulltime or part-time employers or employees of labor. The analytical method employed for the study is the Interpretative Phenomenological Approach (IPA), aimed at understanding the respondent's opinion and views about the subject matter.

The approach sharpens our understanding of participants' subjective world experiences with an assumption that different radical ideas can be interpreted from people's similar objective experiences [20]. In accordance, the analysis was processed using interpretative repertories where participants' responses were grouped to recognize common themes. Studies have employed the IPA method to understand some concepts of, which is the work of the study where the IPA was used to reveal the understanding of implicit theories of learning [20]. Furthermore, Background Check International (BCI) was also used as a case study for the research. The company's marketing initiatives were examined and compared to the company's financial growth to examine the impact of social media on the development of the businesses.

\section{Results}

\section{Response To Interviews}

Qualitative research was conducted where I interviewed some key staff of BCI on their thoughts on the impact of social media marketing on the activities and financial performances of the company. Below are some of their comments.

\section{What Some Background Check International Staff Have to Say}

Ayomide Adegebo, member of the Internet \& Social Media Marketing Unit

Social media now plays a tremendous role in BCI's business growth. Apart from the fact that social media can help boost sales (which many business owners mainly focus on), it could also serve as a great platform to engage customers. Valuable feedback could be gotten that would help improve products or services and customer relations. One could take queries and inquiries via these platforms.

Social media could also help build trust between a brand and its customers. The media gives much room for communication between brands and their customers, fostering trust and giving a sense of belonging to the customers. Wise brands even consciously use social media to build a brand community.

Lastly, businesses that look forward to existing in their industry and wish to lead need social media to build thought leadership. Though this has to deal more with content marketing, social media remains the viable means of sharing content. Intelligent brands that want to lead their industry must position themselves well on social media and sell free and helpful content to their audience.

\section{Ify Onwu, Assistant Head, Operations}

Social media has a wider range of the masses than conventional media, and I strongly believe that Growth is a game of numbers. The more comprehensive your network, the more people you could reach, just like we presently do in Background Check International. The more prospects a brand can reach out to through the social media platforms, the higher the brand's business will grow.

\section{Emmanuel Sohe, A member of the Business Development Team}

The impact of social media marketing on business growth cannot be oversized. My little preview of academic literature has shown that 
sufficient research has been done on the subject in developed parts of the world and some developing nations such as India. Their result indicates a significant positive relationship between social media marketing and business growth. However, most of the research emphasized the importance of intervening factors that also affect the relationship, such as the firm's trustworthiness, the attractiveness of the products, type of goods, and services.

\section{Kola Adeaga, Operations Head}

Social media pushes organizations' products to a wider audience because almost everyone now has a presence on various social media; social media also make getting a company's messages through to their target markets easier and faster. Social media platforms keep growing by the day, and if properly utilized, leads and prospects are easily generated, and people refer others to a brand they have a positive experience. So, enormously, social media marketing boosts business growth effectively.

\section{Comments from LinkedIn Respondents}

I asked my over 23,000 connections on LinkedIn these questions: "The Role of Social Media in Business Growth" What is your candid response to this? Your input will be appreciated. Thanks.

Below are some of the responses I received:

\section{Taiwo Oyekanmi}

Founder, Axiom Institute \| Investment Banking || Research and Data Analyst (stata, Spss, Excel, Atlas ti, Tableau \& R)

In any business, the impact of its reach and level of awareness can never be overemphasized. Social media is the new platform harnessed by business owners in place of the traditional forms of advertisement to promote their level of understanding and reach. It performs numerous roles in bridging the wide gap between products/services and consumers.

This is because of its strengths in

1. the volume of users
2. ease of use

3. speed in terms of dissemination of information.

Just to mention a few. Social media is one of the best ways to enhance business growth.

\section{Emmanuel Akinwunmi Oduntan}

\section{Digital Media Strategist at Capper Productions Ltd}

I believe that social media (SM) Marketing has a tremendous impact on the business world and business growth. SM marketing is all about building relationships, building a community made up of relationships with the right people or target audience.

\section{Fasoranti Damilola}

Chief Listener, Prikkle Academy | Writer | Tedx Speaker | Helping Fearful Dreams to Finally Launch Fearlessly

1. I once sent out an application for a grant. After they looked through the application, they sent a mail to request for all our social media handles. When they saw the things that were there, they said it convinced them to approve the grant. Of course, that grant was a boost to our work.

2. My organization doesn't put out a call for volunteers. What we put out on our social media takes the people to our website, and they sign up by themselves.

3. We have received donations from people who saw what we put out on social media and reached out to us, which led to a boost in our work.

All in all, I must say, we have a purpose, design, strategy, and plan for our Social Media Activities.

\section{Rahmat Eyinfunjowo}

Interested in opportunities in agriculture, innovations, research, SDGs, consulting, and people development

I am a witness to social media being used as a tool for business expansion. 
A friend started a fashion design outlet, and she was a perfect tailor. Alas, her expertise did not bring her clients in droves the way she anticipated. I suggested social media. We took her to Instagram, Facebook, and Twitter. I managed the content, and it worked with strategy and consistency from our end. We still can't believe it. This has worked with other people too.

My point is this; social media, with the growing number of smartphone users, can be a tool for business growth. But then, one needs the right content which directly appeals to your would-be clients, a strategy by which the content will be delivered to capture their attention, and the consistency to keep it. Otherwise, the online presence of a business owner would only fall into the category of one of 'them.'

I think here's where branding comes in because you're after selling a brand.

\section{Michael Ikechukwu Diogu, FIMC, CMC}

CEO/FOUNDER, "BLOGGER" At Mike Diogu's Blog, Abuja, FCT, Nigeria, West Africa. Self-employed

Social media drives marketing gimmicks by selecting and fulfilling consumers' desires and needs to maximize or optimize profitability per unit of capital invested in the enterprise.

\section{Hassan Ogunwemimo Seun}

Assistant Programme Manager at NOMRA Network of Migration Research on Africa

No gainsaying, social media marketing increases coverage and increases potential clients with wider range. Unless subjected to scientific inquiry, the magnitude of such increase may remain unclear, but I think social media marketing has the edge over traditional marketing.

Having said this, who says both cannot be combined? A simultaneous adoption of both can only rake in more positives to the organization.

\section{Segun Ogundairo}

Content creator \& Story Teller | Hilltops digital marketing | Communication Manager | Co-founder JESS

Social media's role in business growth is one big thing. The essence of business is to make a profit, and profit can only be made when your customers/buyers patronize you. This overtime had made people rely on traditional advertising to create awareness to the public and garner potential buyers.

Social media has disrupted this with massive results. Social media helps grow personal relationships between the seller and buyer; with conversation and direct communication, your customer begins to trust you.

Social media helps with Content sharing. With social media, your customer sees Content from time to time. He knows your next product, its benefit, where to get it, and all.

Social media helps to accelerate revenue. Conversion rates in social media are high compared to any means of marketing/Advertising; with just a click of the button, you can make sales with customers.

Social media helps with Analytics, and you can monitor your customers what they buy most times? what sites do they visit? How often do they visit? what are they searching for? What's their age ranges are? With this information, you can re-target your customers.

It has added a new dimension to the sales process by providing a direct and immediate line to potential customers.

\section{Discussion}

\section{The Impact of Social Media Marketing on Background Check International}

Background Check International (BCI) officially commenced business on April 1, 2005. The company happens to be the pioneer background screening company in Nigeria. 
As a new industry in a large and diverse country like Nigeria, embarking on advertisements that will make the awareness of the company's existence possible was an uphill task. The company at the start also intended to patronize foreign organizations in different parts of the world.

Our initial means of marketing our services was the press media, and our biggest challenge with this was the huge budget that is required before the company is well known and also the number of repeated adverts that we had to run for the necessary impact of the company and its services can be felt nationally.

About seven years ago, the management of BCI decided to seriously embark on social media marketing as an alternative to the conventional press media means of advertisement and public relations strategies. We chose two main social media platforms, Facebook and LinkedIn.

To get started, we created our Facebook BCI group with the link: https://www.facebook.com/groups/ and a BCI Facebook page with the link: https://www.facebook.com/backgroundcheckint ernational/. As the face of the company, I also created my Facebook and then LinkedIn account and a LinkedIn business page for BCI. The LinkedIn platform is primarily created to encourage business-to-business activities and connections. Since most of the key decisionmakers (KDM) that we were targeting as prospects were on LinkedIn, we seriously concentrated our marketing efforts on LinkedIn. We started by sending invitations to connect with the KDMs, and at the same time, we were searching for all relevant LinkedIn groups where we can find prospects that will be interested in our services.

LinkedIn also has the inbox message facility that we use most of the time to introduce BCI to the prospects that accept our connection invitation. To properly introduce $\mathrm{BCI}$ to LinkedIn users, we ensure that we design captivating and message disseminating adverts on a daily basis.
At first, our designs were outsourced to professional advertising agencies. But the challenge we had with the agency was the fact that they were struggling to comprehend our services and how to portray them to the general public. So, the management decided to set up an in-house publicity and social marketing unit. Part of the unit's duties was to come up with copies, contents, and designs for our various social media adverts.

The in-house strategy has been one of the greatest and wisest decisions the management has ever taken since the company's inception because it has eliminated the advert budget we usually allocate for advertisements. In actual fact, our yearly budget for advert has reduced so drastically.

The Publicity unit also pushes information contents of our services to our Facebook page, website, blog, and LinkedIn article facility. The company also utilized the LinkedIn and Facebook advert promotion facilities.

Aside from the Facebook and LinkedIn platform, the advent of WhatsApp has also been a game-changer for BCI. We use WhatsApp to push graphics, adverts, and content directly to our phone contacts and prospects. The documents are pushed out through several broadcast groups that we have created.

The company has succeeded in synchronizing our LinkedIn, Facebook, and Twitter together to the extent that any information posted on one platform will all reflect on the two other platforms.

BCI also makes do with YouTube in promoting its product and business through videos. We find YouTube to be a very perfect and better replacement for television advertisement, and the interesting aspect of this is that the YouTube activities we embark on are free! This cannot ever be compared with the heavy budget needed to do the same on either private or State-owned television stations.

The in-house social media unit of Background Check International also makes do of uploading 
information and marketing content to the company's blog on a regular basis.

Social media made it possible for the company to become a global company with customers cutting across continents and countries because there is no limit to the extent of where again advert or publicity placed on social media can go.

\section{Impact on BCI's Financial Performance}

The most significant impact of our embarking on online and social media marketing kept on reflecting in the upward financial performance of the company on a yearly basis. In the last five years, our advertisement and publicity budget has been in the region of about $3 \%$ of the annual gross revenue, instead of the recommended 10\% of gross yearly income [26, 27]. In the fiscal year of 2017 , the company was very prominent on social media in terms of PR and adverts without necessarily spending more. It paid off at the end of the year, with the company having its best fiscal performance, despite the fact that the whole country was experiencing a recession.

With the organization's climbing and progressive financial performance in the last fiscal year, I can categorically submit that social media marketing has a very significant impact on performance.

\section{Conclusion}

Social media platforms have been one of the amazing inventions in the $21^{\text {st }}$ Century. The adage that the world is now a global village has eventually become a reality by the virtue of social media.

The exciting aspect of all these is how social media have replaced the electronic mail and SMS of intelligent phones because now you can chat on message directly prospects from the social media. The days of writing business proposals and the documents not getting to the organization's key decision-makers are over. Proposals are now sent and received via social media.

Beyond all reasonable doubt, social media will continue to disrupt any remaining aspect of traditional marketing that may still survive today.

\section{Acknowledgement}

All glory and adoration are due to Almighty God, the source of all knowledge and inspiration for his mercies and kindness, and for granting me the privilege to complete this study.

My profound gratitude goes to my dear wife, the wife of my youth Mrs. Toyin Olugbodi for her immense support and understanding during the study. Thank you for standing with and me through it all. I would love to appreciate my dear family for their support and encouragement in the same vein.

I extend my heartfelt gratitude to everyone who participated in this research and contributed in any way to make this a success. Thank you.

My sincere gratitude also goes to the management and staff of Background Check International for their immense contribution to this great company's growth and development.

Finally, I acknowledge Texila American University for providing this learning opportunity.

\section{Conflict of Interest}

I declare that this study did not receive any funding from any local or international organization, and there was no conflict of interest. 


\section{References}

[1] James "Mick" Andzulis, Nikolaos G. Panagopoulos, \& Adam Rapp. A Review of SocialMedia and Implications for the Sales Process. Pages 305-316. Published online: 23 Sep 2013. https://doi.org/10.2753/PSS0885-3134320302.

[2] Gomber, P., Koch, JA. \& Siering, M. Digital Finance and FinTech: current research and future research directions. J Bus Econ 87, 537-580 (2017). https://doi.org/10.1007/s11573-017-0852-x.

[3] Scott M. Fitzpatrick, Stephen McKeon (2019). Banking on Stone Money: Ancient Antecedents to Bitcoin. First published: 07 June 2019 https://doi.org/10.1002/sea2.12154.

[4] Odusina, Ayokunle Olumide (2014). Automated Teller Machine usage and Customers Satisfaction in Nigeria.

[5] Kagermann H. (2015) Change Through Digitization Value Creation in the Age of Industry 4.0. In: Albach H., Meffert H., Pinkwart A., Reichwald R. (eds) Management of Permanent Change. Springer Gabler, Wiesbaden. https://doi.org/10.1007/978-3-658-05014-6_2.

[6] Okonkwo, U. Sustaining the luxury brand on the Internet. J Brand Manag 16, 302-310 (2009). https://doi.org/10.1057/bm.2009.2.

[7] DataReportal (2021), "Digital 2021 Global Digital Overview," retrieved from https:/datareportal.com/reports/digital-2021-globaldigital-overview

https://doi.org/10.1016/j.techfore.2017.05.038.

[8] Christofer Laurell, Christian Sandström, the sharing economy in social media: Analyzing tensions between market and non-market logics, Technological Forecasting and Social Change, Volume 125, 2017, Pages 58-65, ISSN 0040-1625.

[9] Bedell, J. (2010, September 20). What is the Difference Between social media and Social Media Marketing?

[10]Culnan, M. J., McHugh, P. J., \& Zubillaga, J. I. (2010). How large US companies can use Twitter and other social media to gain business value. MIS Quarterly Executive, 9(4).

[11] Kietzmann, J. H., Hermkens, K., McCarthy, I. P., \& Silvestre, B. S. (2011). Social media? Get serious!
Understanding the functional building blocks of social media. Business Horizons, 54(3), 241-251. [12]Zontanos and Anderson (2004). Relationships, marketing, and small business: an exploration of the links in theory and practice, Volume 7(3):9- Sep 1, 2004.

[13]Fruhling and Digman (2000). The impact of electronic commerce on business-level strategies. Journal of Electronic Commerce Research 1 (1), 13, 2000.

[14] Carraher, S.M., Parnell, J., \& Spillan, J. (2009). Customer service-orientation of small retail business owners in Austria, the Czech Republic, Hungary, Latvia, Slovakia, and Slovenia. Baltic Journal of Management, 4 (3), 251-268.

[15] Ravi, K., \& Ravi, V. (2015). A survey on opinion mining and sentiment analysis: Tasks, approaches, and applications. Knowledge-Based Systems, 89, 14 46.

[16]He, W., Zha, S., \& Li, L. (2013). Social media competitive analysis and text mining: A case study in the pizza industry. International Journal of Information Management, 33(3), 464-472.

[17] Daniel Nation, Lora L. Reed, \& Alan Swan (2010). Innovations and Future Directions for Experiential Learning for a Large Online Business Degree Program. Vol. 41 (2014): Developments in Business Simulation and Experiential Learning.

[18] Cohen, L. S. (2009, April 30). Is there a difference between social media and Social Networking? Retrieved December 4, 2010, from lonscohen:

http://lonscohen.com/blog/2009/04/differencebetween-social-media-and-social-networking/. [19]Hartshorn, S. (2010, May 4). 5 differences between social media and Social Networking. Retrieved December 1, 2010, from social media today:

http://www.socialmediatoday.com/SMC/194754.

[20] Stephen R. Carpenter, Harold A. Mooney, John Agard, et al. (2009). Science for managing ecosystem services: Beyond the Millennium Ecosystem Assessment. PNAS February 3, 2009106 (5) 13051312; https://doi.org/10.1073/pnas.0808772106.

[21] Hollier, P. (2009, January 29). The "intangible" benefits of social media. Retrieved December 4 , 
2010 from

SEO

wizardry:

http://seowizardry.ca/The_Wizards_Blog/the-

$\%$ E2\%80\%9Cintangible $\%$ E2\%80\%9D-benefits-ofsocial-media/.

[22] Digital Buzz (2012). Infographics: Social Media Statistics for 2012.

[23] Small Business Trends (2013). Complete History of social media: Then and Now retrieved from: https://smallbiztrends.com/2013/05/the-completehistory-of-social-media-infographic.html.

[24] Statista (2021). Most popular social networks worldwide as of October 2021, ranked by a number of active users retrieved from: https:/www.statista.com/statistics/272014/globalsocial-networks-ranked-by-number-of-users/.
[25] Security (2016) Facebook is the Most Popular Social Media Platform retrieved from: https://www.securitymagazine.com/articles/87597facebook-is-most-popular-social-media-platform. [26] Pourkhani, Kh. Abdipour, B. Baher and M. Moslehpour (2019). The impact of social media in business growth and performance: A scientometrics analysis.

[27] Stelzner, M. (2009, May 22). Social Media vs. Social Networking: What 's the difference. Retrieved December 4, 2010, from examiner:http://www.examiner.com/networking-innational/social-media-vs-social-networking-what-sthe-difference. 


\title{
The Electronic Payment Systems in a Developing Economy with Reference to Guyana
}

\author{
Imran Khan \\ Ph.D. in Strategic Management, Texila American University, Guyana
}

\begin{abstract}
The general intention of this Publication is to feature Electronic Payment Systems in a Developing Economy with reference to Guyana and the bearing comprising the advantages in cultivating payment systems while heightening safety, the efficiency of payments, and cost savings. The continuous transformation of a developing economy's payments system will support monetary growth through the fiscal system for its sustainability and enables proficient financial interposition. This publication further highlights the need for frequent evaluation and supervision for the continuous modernization of electronic payment systems to the benefit and referencing to the developing economy of Guyana. Critical areas that are essential which emphasis have been placed upon but needs further attention in addressing, are as follows:

1. Increase the rate of finalizing a transaction through its related operations within actual or rapid time, as time is money. Currently, the rate of one transaction varies (by hours).

2. Decrease of paper materials and handling costs which generally eases functional cost.

3. Payment assurance and dependable guard against illegal entry to the client's account in ensuring safe dispensation.

This publication has formed the basis to associate investors behind the target to endorse a modern payments system infrastructure that is required for a developing economy with reference to Guyana with the objective of restructuring, empowering discussion and the propelling effect in generating inventive and country-specific electronic payment solutions. It should be noted that a substantial amount of transformation has occurred to date with reference to Guyana.
\end{abstract}

Keywords: Developing Economy, Electronic Payment Systems, Implementation.

\section{Introduction}

Electronic Payment Systems (EPS) development generally has been described as difficult and unnatural with varied challenges in developing countries which has socioeconomic surroundings similar to Guyana in many ways. EPS development, in particular, is faced with trials fluctuating from lack of acceptable lawful backing, power issues, reliability of the human element and deficiency of expert resources, the veracity of data transmitted, absence of infrastructures, interconnectivity, and interoperability, attributable to the country's hitech infrastructure and institutional aptitude.
Many years of progress aid have botched to bring the anticipated results of advancement in most developing countries, partially due to the emphasis on largescale methods and procedures which do not focus on the local organized context faced by money-making agents in those progressing countries. This makes getting the right organized context a key issue for most progressing countries particularly for the development of information systems of electronic payments which are entrenched and much manipulated by the established setting.

Payment systems progression, like every IT growing characteristic, is seen as both public and 
political processes, shaped by governmental and socially created realities of its settings. EPS development therefore may have to take into consideration a whole range of factors, particularly the state of development of the socio-political set up in the country which is usually regarded as poorly developed in growing countries.

The range of factors to consider includes system of actors involved, their connections and effects, and how they are subjective by the organized settings. Another critical factor is the procedures and fundamentals that make up the payment systems which include the payment framework, lawful framework, and official provisions, and how they individually and cooperatively impact growth and advancement.

EPS is an inter-organizational information system that transcends structural boundaries, thus the cooperation of the stakeholders and allocation of resources and how it interrelates and impacts the essential of the payments system may also be key issues in the growth of EPS. Although technology serves as the mainstay driver of EPS, administrative and cooperative issues that shield working arrangements/relationships, authority, procedures, economic, social, trust issues, etc., are other significant issues to be taken into thought for the development of any EPS. Regrettably, EPS growth is often too barely focused on tools, expertise, and structure which progressing countries have encounters with, referenced to Guyana. This has not yielded expected results, particularly in most progressing countries where the other fundamentals of payment systems are poorly established and as such fail to give appropriate support to the payment system framework and gives way to gradual advancement and confidence of the EPS.

A payments system infrastructure requires supplementary institutional arrangements supported by a sufficient legal framework to promote sturdiness. The inducements to advance overall payment system efficacy have been troubled by the recurrent effect of risk shifting due to the uncompensated and unintentional fluctuating of credit and liquidity risks through payment instruments and allied institutions. This covertly challenges the legal, operational and governance fundamentals of the payment system which are organizational, country-specific and signify key facets of the process of payment systems progression. These encounters may have contributed to the unequal accomplishment of comparable restructuring in different countries and resulted in a design-actuality gap that has made the success of planned outcomes difficult in terms of anticipated use, benefits, and costs. The essentials of these institutional features may have to be considered to fix the most applicable mix and suitable improvement approach of the respective developing economy.

This publication is to highlight and substantiate that a developing economy with reference to Guyana has evolved in building a robust, safe, sound, efficient, and inclusive EPS that meets the current and future needs of the country over time. Further, it has and will continue to support monetary activity and financial sector development, advances the use of electronic payments, assists with financial risk mitigation, achieves compatibility with international systems, adheres to the applicable international principles, procedures, and codes. In achieving these, the following gratifications are projected based on data and research approach to be realized in the evolution process:

1. Performing a comprehensive legal \& regulatory framework.

2. Boost the efficiency of electronic payments processing and decrease resolution times for both retail and large value transactions.

3. Entice higher rates of electronic payments, approval by vendors, merchants and other providers of goods and services.

4. Reinforce risk management mitigation across the developing economy's payment system infrastructure.

5. Fortify oversight framework and capability of the respective Central Bank. 
6. Increase availability of electronic payment access networks and support e-commerce.

7. Maximum use of available liquidity in terms of financial resources is made.

8. Participating in payment and settlement infrastructures is on a fair and equal basis.

9. Encouraging healthy competition amongst Payments Service Providers (PSP).

10. Delivery versus payment (DvP) for securities transactions is succeeded and maintained.

11. Payment versus payment ( $\mathrm{PvP})$ for foreign exchange transactions is completed and sustained.

12. Internationally compatibility is recognized and upheld.

13. Cost efficacy is realized and sustained.

14. Openness is wide-ranging based and farreaching throughout the growing economy.

15. Treats are identified, mitigated, and well managed to ensure no or low impact.

16. Adults accept and use cashless payments dominantly.

17. Acknowledgement of electronic payments by vendors, merchants, and other providers of goods and services increases steadily.

18. Payment services, instruments and access channels are interoperable.

19. Rivalry and revolution are supported by level playing fields and equitable access for PSPs to the use of payments system infrastructures.

20. Transmittal service costs fall in line with the regional or global average.

21. Greater use is made of authorized remittance services.

22. Government agencies and quasigovernment entities reduce their use of cash.

23. Irrevocability of settled transactions.

24. Shield of funds.

25. Risk control measures are state of the art.

26. Effective customer complaint \& dispute resolution.

27. Effective fraud prevention and detection measures.

28. Data confidentiality and security.
29. Adherence to national rules

30. Imran - Regulations, and procedures.

31. Achievement of delivery vs. payment.

\section{Growth of Electronic Payment Systems (EPS) Overtime}

Clearing in banking indicates the transfer of funds from one person to another. This clearing of the fund can take place in two (2) ways either through cash or through cheque in cash-oriented societies. There has been no significant change in the cash transactions except for the changes in the value of money in developing countries. However, the cheque clearing system has undergone a lot of changes over time with movement to Electronic Cheque Clearing instead of the manual method.

The origin of a cheque can be traced back to the first century $A D$, where banks used to issue letters of credit wherein the banks used to pay the identified payees as per the instructions. This eradicated the burdensome process of carrying money or previous metals (gold, etc.) which were very risky. Changes have taken place in cheque clearing over the period of time from ordinary cheque clearing to MICR clearing and finally to the latest in clearing 'Cheque Truncation System'. This publication paper sightsees the changes that have taken place in the bank clearing system in the past, present and will also try to picture the future of bank clearing which integrates the electronic payments system in a developing economy with reference to Guyana.

It can be considered that the progression of cashless payments is a result of a new idea to simplify the way of payments, which was then slowly embraced in peoples' life. These days, the payments business is a decisive source of income and figures and a desperate for broader customer relationships. The payment industry continues to progress and offer new creativities to their customers [1].

The World Payment Report [2-4] highlights the critical findings of worldwide non-cash transactions during the last decade and is the 
leading supplier for data, trends of e-payments, and main industry and supervisory initiatives. According to this source, the global non-cash payments can be characterized as a fast-growing market, especially in the emerging markets: emerging Asia, with a growth rate of $43.4 \%$, and Central Europe, the Middle East, and Africa (CEMEA), with a growth of $16.4 \%$ (2014-15 data). While the total non-cash transaction volumes grew $11.2 \%$ during 2014-2015 and reached 433.1 billion, the rate of progression in Europe changed from $7.3 \%$ to $7.5 \%$. Perceptible growth was shown in the following countries: Germany, Spain, Finland, Ireland, Sweden, and Denmark. It should be noted that China is in third place with 38.1 billion transactions $(63.2 \%$ growth rate).

Electronic payment transaction technological expertise is associated encouragingly to actual economic collections. This has been more obvious with the Euro economy countries. The findings of the European Central Bank Working paper 'Retail Payments and the Real Economy' [5] provided deep analyses of 27 European Member States over the period 1995-2009 and proved 7 main hypotheses, among which, the following may be mentioned: Efficient non-cash retail payment instruments accelerate monetary growth; Cheque payments exercise a lower contribution on GDP, utilization and commerce in contrast to other non-cash payment instruments; The optimistic impact of credit transfers on actual economic development is greater in the euro area countries than in the noneuro area countries; The acceptance of new payment technologies results in supplementary economic progression. The different means of non-cash payments are growing around the world. Modernisms are more relaxing to use for young people. For example, emerging Asian markets are driving to accelerate e-commerce progression. Despite this, 'E-Payments in Emerging Markets [6, 7] states that many countryside areas still do not have banking systems, while those that do are slowly moving from cash to electronic payments similar to what is existing in Guyana.

It was further highlighted the role of government in the investment in new technologies, managing e-instrument security, enhancing financial inclusion, and leveraging existing market players. What will be the next stage: it's clear that the future is bright and that opportunities abound with carefully planned strategies and reliable partners [6, 7], EPayments in Emerging Markets, A First Data White Paper, Journal of Payments Strategy and Systems, Volume 7, Number 4). The specific area of e-payments is electronic business, which created new opportunities for sending and receiving of payment instructions. The paper [8] E-payments in Europe - The Euro system's Perspective investigates the fresh approaches and techniques, which developed to adopt outdated payment instruments for use in the internet: credit cards, credit transfers, and debit instruments.

The development of e-business helped to raise a new type of payment service providers and advance new types of electronic instruments such as prepaid cards, electronic wallets, and others together with the security issues of those instruments. The main conclusion is that the Euro system endeavors, in co-operation with standardization bodies and market participants, to help strike the right balance between competing and commonly agreed standards. Another in-depth survey on the development of electronic money and internet and mobile payments was published by the Bank of International Settlement (BIS) updated Survey, which included the information collected from 95 countries around the world. The focus of this survey was not technical purposes, but the market impact of innovations. Based on the information and data provided by the Survey respondents from the individual country, comparative tables on the use of innovative products and systems were designed. In the survey, the data was collected in end-2002 or 
2003, and covered schemes that were being considered, piloted or implemented [9].

The acceptance of the new means of cashless payments has had a significant effect on developing economies with reference to Guyana. This was proved by the study Cashless payment and economic growth [10]. Specifically, the impact of cards, telegraphic transfers, electronic money, and cheques on the economies of Australia, Belgium, France, Germany. and Portugal for the period of 2000-2012.

The research was piloted by the use of Pedroni's outstanding integration and the Panel Course Error Correction Model. The main message stated from this report is that the acceptance of one type of cashless payment will affect another type of cashless payment in the short run, the consequences of accepting cashless payment on economic development can only be significantly observed in the long run. Hence, any policy that promotes cashless payment will not affect the economy immediately but on a long-term basis.

A payment card is the most popular non-cash payment instrument in the world. It allows consumers to retrieve its funds in the bank which has evolved with reference to Guyana over time and has been used widely of recent especially in the COVOID-19 Pandemic. Increased card usage in the world gives rise to the main question: what kind of benefits it brings to the country. The answer to this question could be found in Moody's Analytics, which offers unique tools and best practices for calculating and overseeing risk through proficiency and know-how credit analysis, business research, and financial risk management. Moody analytics [11] conducted two different research on the encouragement of payment card transactions on the country with the initiative of Visa International. In the first research conducted in 2013, the data of 56 countries was [11] analyzed for the period of 2008-2012 and was stated that the use of credit and debit cards added 983 billion US dollars to the GDP of these 56 Countries.
A similar analysis was conducted in 2016 for the data of 70 countries for card transactions in the period of 2011-2015. According to this research, payment cards usage added 296 billion US dollars to GDP, which means 2.6 million new jobs on average in each year. The main message was stated 'Card usage makes the country more efficient, yielding a meaningful boost to country growth, year after year, through a collection of factors including transaction efficiencies, consumer access to credit and consumer confidence in the payments system overall' [12]. The effect of Debit and credit card transactions together with cheque transactions on GDP was also calculated by [13] 'Statistics Paper Series' of European Central Bank 'Nowcasting GDP with electronic payments data'.

Many Authors have divided the data received from the Canadian Payment association and Bankers' Association for the enquiry in two spans: the first, through the end of 2009. Credit card data were available to them from 2010. The longer data set which extends through April 2012 contained debit and cheque data. In this particular model, with debit card transactions included some enhancement in the correctness of the earliest now casts were found. The outcomes of the study give a big picture of the development in newscasting over time. 'The Analysis of the Factors Influencing on Electronic Payments and Relationship among Azerbaijan's Economy with Them' [14, 15] gives the broad analyses of factors that have a negative influence on the development of cashless payments on Azerbaijan's country as an example. The rise of electronic payments reduced the size of the shadow economy in Azerbaijan correspondingly.

Moreover, unlawful, and small income level, low pension and great utilization, unorganized commerce, infrastructural possibilities and technological level, payment culture and financial literacy, gaps in lawmaking, and other such factors that influence adversely on the growth of cashless payments are analyzed and 
the endorsements have been given in this publication. In addition to these, international experience has been examined in terms of managerial and encouraging guidelines in order to improve cashless payments and endorsements and have been made in this direction with reference to Guyana.

A substantial optimistic relationship between the e-payment system and country development in terms of real GDP per capita and commerce per capita was found in the 'Review of Transition to Cashless Economy in Nigeria' by the authors [17-19]. The main finding is that most of the non-cash payments are provided through bank accounts. With this study, it was highlighted that only Automated Teller Machine (ATM) operations were revealed on economic growth and development something we have seen and keep growing in developing countries with reference to Guyana.

In today's world, economic relations become an integrated part of the culture. The most distinctive such connection in a market country, where the estimation for the condensed services, products, etc. Such estimations can take both cash and cashless form. The form of cash payments is typical for countries with less developed countries with reference to Guyana. In the more developed countries, the transition to non-cash was evident because of a number of compensations. Many countries have both forms of cash payments. Their number may vary depending on the development in the country of science, technology, education, social sphere, etc. if considered that the form of payments in terms of compensations and difficulties, the noncash form is more beneficial in terms of costs, speed, and other costs than cash. Non-cash payments are payments (payments) made without the use of cash, through the movement of funds to accounts with credit organizations and offsets of joint entitlements.

The adequate e-transactions guideline can be used as a mechanism for development. If we talk about developed countries like USA and the EU, cashless payments are $93 \%$ and $91 \%$ respectively. The remunerations provided by epayments are quick access to monetary markets, immediately transactions between entities everywhere in the world, the increase in financial activity, and most important - they are one of the items to support further country growth [20].

The guideline consequence and support of this publication is the comprehension of why effectual EPS development is challenging in certain organizational perspectives. This consideration could help in constructing the mandatory organizational competence and monetary environment that enhances the effective progression of payment systems in a developing country with reference to Guyana. The input for the educational society is an enhanced perception of the impact and interactions of the rudiments of the payment system in the effective growth of payment systems in Guyana. It also features the remunerations of inserting business principles combined with institutional theory in the progression of information systems, such as EPS which is interwoven with monetary and financial interests of relevant stakeholders. For practitioners, the support may be a guide that helps in building organizational aptitude and a surrounding conducive for effective payment systems progression and growth. Thus, the paper reveals a correlation between e-payment increasing and GDP growth. It was researched how the digital nature of money influences the financial system at a whole.

Besides, uploaded dimension of credit-digital nature of money is given. The usage of cashless payment is closely related to the level of economic development. On the one hand, a higher level of well-being and development of the financial system in richer countries encourages cashless transactions. On the other hand, cashless payments contribute to accelerating economic development: through the spreading of electronic payments that can cause consumption growing. The adequate e- 
transactions regulation can be used as an instrument for growing.

The paper describes the latest trends in IT development and its influence on financial sector (especially cashless payment) the global economy faced. So, South Korea, Sweden, Iceland are leading countries. In the cause of Ukraine, there is a positive IT dynamic. If we talk about the USA and EU, cashless payments are $93 \%$ and $91 \%$ respectively. The benefits provided by e-payments are rapid access to financial markets, immediately transactions between entities everywhere in the world, the increase in financial activity and most important - they are one of the items to support further economic development.

\section{Methodology}

The approach used for the purposes of this research is an inductive one. It began with specific observations, which was used to produce generalized theories and conclusions drawn from the research as outlined in the Reference Section mentioned below. The reason for occupying the inductive approach was that it takes into account the context where research effort is active and most current based on already available data from prior research.

For the purposes of this publication, comprehensive observations with related researched data and information were incorporated along with unstructured and informal interviews which helped with identifying participants' emotions, feelings, and opinions regarding the research subject. The unstructured interviews offered flexibility in terms of the flow of the interview, thereby leaving room for the generation of conclusions that were not initially meant to be derived regarding a research subject.

As far as data collection tools were concerned, the crafting of this publication was built primarily from researched artifact collection of information and data as outlined under the Reference Section below. Further, the research design is Analytical and Exploratory. In an analytical approach, the available literature were critically evaluated with the facts and information related to the research being conducted. In the exploratory approach, tried to explore the new avenues for digitalization, as it is a review paper, the data is confined only to secondary sources and no scope for sampling and research tools application.

\section{Results and Discussion}

This publication highlights the interactions of the institutional arrangement with the technological infrastructures and other elements of the EPS, identifying the critical roles. The development of EPS depends not only on the effectiveness of the technical infrastructures but on building a viable institutional capacity that will provide a suitable environment. This publication further substantiates the institutional arrangements and their suitability in meeting the needs of society, the interest of the stakeholders, and the overall continuous development of EPS concerning Guyana.

This publication's output is the understanding of problems encountered during the policy implication, contribution, and effective EPS development in specific institutional contexts. This understanding could help build the required institutional capacity and an economic environment that enhances the effective development of payment systems in a developing country, such as Guyana. The contribution for the academic community is an improved understanding of the influence and interactions of the elements of the payment systems in the effective development of payment systems in Guyana. It also highlights the benefits of applying economic principles combined with institutional theory in developing information systems, such as EPS, which is intertwined with stakeholders' financial and economic interests. For practitioners, the contribution may be a guide that helps in building institutional capacity and an environment suitable. Thus, the paper reveals a correlation between e-payment increase and GDP growth. It was researching 
how the digital nature of money influences the financial system as a whole. Besides, uploaded dimension of credit-digital nature of money is given. The usage of cashless payment is closely related to the level of economic development. On one hand, a higher level of well-being and development of the financial system in richer countries encourages cashless transactions and on the other hand, cashless payments accelerate economic growth by spreading electronic payments that can cause consumption to grow. Adequate regulation can be used as an instrument for increasing e-transactions.

The paper describes the latest trends in IT development and their influence on the financial sector (especially cashless payment) the global economy faces. So, South Korea, Sweden, Iceland are leading countries in the implementation of EPS. In the case of Ukraine, there is a positive IT dynamic. In USA and EU, cashless payments are $93 \%$ and $91 \%$, respectively. The benefits provided by epayments are rapid access to financial markets, immediate transactions between entities everywhere in the world, the increase in financial activity, and, most importantly, items to support further economic development.

Further, this publication revealed the correlation between e-payment increase and GDP growth. The researcher studied the influence of the digital mode of payment in the financial system as a whole. Besides, the loaded dimension of the credit-digital nature of money is also discussed. The usage of cashless payment is closely related to the level of economic development. On one hand, a higher level of well-being and development of the financial system in richer countries encourages cashless transactions. Further, it is also understood that cashless payments accelerate economic growth by spreading electronic payments that can cause consumption to grow.

\section{Conclusion}

A modern electronic payments system for a developing country referenced Guyana with unassertive payment volumes is apparent. The objective is to undertake a comprehensive study of the cost of cash and other payment instruments customary in Guyana to provide a robust platform for the continuous construction and modernizing of Electronic Payment Systems and reforms. A developing country concerning Guyana is recognized as a cash payment cultured country. With most payments are done primarily by cash and cheques, which increases the risk of consumers walking around with lots of money and the cost-effectiveness of supplying paperbased payment instruments. However, over time this has changed progressively integrated with the deadly COVID-19 Virus Pandemic. The pandemic forced many in Guyana and globally to use electronic payments to avoid or reframing from crowds and long queues (lines).

The progression of EPS will hinge on the efficacy of the ever-changing technological infrastructures and on constructing a feasible organizational facility that will provide an appropriate environment. The New Institutional Economics (NIE) theory will thus empower this publication to emphasize the organizational engagements and appropriateness in meeting society's needs. It also meets the interest of the stakeholders and the overall growth of EPS.

A well-developed and efficient payment system is critical for a country's growth and financial stability. By virtue, Guyana undertakes an all-inclusive and strategic restructuring. The transformation of its developing payments system will enhance the use of electronic payments by its stakeholders and the country as a whole over time. Non-cash payments are of great economic significance in fast-tracking the trade of funds, reducing the cash needed for circulation, and reducing circulation costs. A network of commercial banks aids the extensive use of non-cash payments (they are six in Guyana presently). The state's interest in their development, both for the above reason and to examine and control macroeconomic processes that have evolved in Guyana over time. With continuous modernization and reforms, 
Guyana's payments system is in the quest to move away from cash payments to electronic payments. It is estimated to save the country approximately US6.5 billion annually and improve its Gross Domestic Product (GDP) significantly and steadily over time. It is established that with focus should be placed on promoting an infrastructure that includes payment systems such as a fully Automated Clearing House (ACH) inclusive of Electronic Funds Transfer (EFT) and Electronic Cheque Clearing ECC), Real-Time Gross Settlement (RTGS), Central Securities Depository (CSD) and Society for Worldwide Interbank Financial Telecommunications (SWIFT) systems. The focus will realize and benefit Guyana extensively over time as a developing economy in the Western Hemisphere.

\section{References}

[1] Jumba, J., \& Wepukhulu, J. M. (2019). Effect of Cashless Payments on the Financial Performance of Supermarkets in Nairobi County,Kenya. International Journal of Academic Research Business and Social Sciences, 9(3), 1372-1397.

[2] World Bank Payments Report 2017, https://worldpaymentsreport.com/resources/worldpayments-report-

2017/\&ved=2ahUKEwjujrye7qn0AhU5SjABHRZ2 C98QFnoECAoQAg\&usg=AOvVaw185X540z3hX n8CV6t4uzav.

[3] Demirgüç-Kunt, A., \& Klapper, L. F. (2012). Measuring financial inclusion: The global findex database. World bank policy research working paper, (6025).

[4] Cirasino, M., \& García, J. A. (2008). Measuring payment system development. World Bank, Washington, DC.

[5] European Central Bank Working paper 'Retail Payments and the Real Economy' (August 2013), https $\% 3 \mathrm{~A} \% 2 \mathrm{~F} \% 2 \mathrm{Fwww}$.ecb.europa.eu $\% 2 \mathrm{Fpub} \% 2 \mathrm{~F}$ pdf $\% 2$ Fscpwps $\% 2 F e c b w p 1572$.pdf\&usg=AOvVaw ogjQun3GFdUGsuRKr4UbTm.

\section{Acknowledgement}

This publication is prepared as part and requirement of my $\mathrm{PhD}$ program. I am grateful for the support provided by Texila American University inclusive of their sub-entity Texila International Electronic Journal, my guide Dr. Sasirekha A. and co-guide Dr. Santhi N.S.

\section{Conflict of Interest}

Due to the methods used for this publication, there were no significant conflict (s) of interest encountered as the information gathered from sources was mentioned with and kept with confidentiality with usage solely for the purpose of this publication.

[6] Amrish Rau (2013). E-payments in emerging markets, Journal of Payments Strategy \& Systems, 7(4), 337-343.

[7] Amrish Rau [2013], E-Payments in Emerging Markets, A First Data White Paper, Journal of Payments Strategy and Systems, Volume 7, Number 4).

[8] E-payments in Europe - The Euro system's Perspective (16 September 2002), https://www.ecb.europa.eu/pub/conferences/shared/ pdf/epayments.pdf\&ved=2ahUKEwizgcbu86n0Ah WEaDABHbbaC-

AQFnoECAEQAg\&usg=AOvVaw1gqZonfPqcGgS w9y1AEfdz.

[9] Survey of developments in electronic money and internet and mobile payments [March 2004], Bank for International Settlements, https://www.bis.org/cpmi/publ/d62.htm\&ved=2ahU KEwjKlqXN9Kn0AhXsSjABHVWNBikQFnoECA cQAg\&usg=AOvVaw3F1XIfeeQf7FzJ2cK7ZcyU $\backslash$. [10] Tee, H. H., \& Ong, H. B. (2016). Cashless payment and economic growth. Financial innovation, 2(1), 1-9. https://doi.org/10.1186/s40854-016-0023$\mathrm{z}$.

[11] Moody analytics analyzed for the period of 2008-2012, https://usa.visa.com/visa- 
everywhere/global-impact/moodys-analytics-studythe-global-impact-of-electronic-

payments.html\&ved=2ahUKEwjEyfWV96n0AhVlT

TABHdArAmgQFnoECAcQAg\&usg=AOvVaw2Bs wwaNPC6uXsXFicS2mkx.

[12]Zandi, M., Singh, V., \& Irving, J. (2013). The impact of electronic payments on economic growth. Moody's Analytics: Economic and Consumer Credit Analytics, 217(2).

[13] Galbraith, J. W., \& Tkacz, G. (2015). Nowcasting GDP with electronic payments data (No. 10). ECB Statistics Paper.

[14] The Analysis of the Factors Influencing on Electronic Payments and Relationship among Azerbaijan's Economy with Them' (2016), https://smartlib.umri.ac.id/assets/uploads/files/d382d -a0706020110.pdf\&ved=2ahUKEwjYypvFan0AhVmQzABHQt_D_kQFnoECAAQAg\&usg=A OvVaw05YwWetukE2zigJtF8mZri.

[15] Taghiyev, K., Eminov, S. I., \& Guliyev, S. R. (2016). The analysis of the factors influencing on electronic payments and relationship among Azerbaijan's economy with them. IOSR Journal of Economics and Finance (IOSR-JEF), 7(6), 01-10.

[16] Taghiyev, K. R., Eminov, S. I., \& Guliyev, S. R. (2016). The impact of cashless payments on economic growth in Azerbaijan. International Journal of Research in Social Sciences, 6(12), 296310.

[17] Oyewole, O. S., Gambo, J., Abba, M., \& Onuh, M. E. (2013). Electronic payment system and economic growth: a review of transition to cashless economy in Nigeria. International Journal of Scientific Engineering and Technology, 2(9), 913918.

[18] Akhalumeh, P. B., \& Ohiokha, F. (2012). Nigeria's cashless economy: The imperatives. International Journal of Management and Business Studies, 2(2), 31-36.

[19] Mieseigha, E. G., \& Ogbodo, U. K. (2013). An empirical analysis of the benefits of cashless economy on Nigeria's economic development. Research Journal of Finance and Accounting, 4(17), 11-16.

[20] Slozko, O., Pelo, A. (2014), The Electronic Payments as a Major Factor for Further Economic Development, Economics and Sociology, Vol. 7, No 3, pp. 130-140, https://www.economicssociology.eu/files/14_44_Slozko_Pelo.pdf. 


\title{
The Potential of Technology within the Agribusiness Industry in the Emerging Market of Ghana
}

\author{
Richard Asante $^{1 *}$, Rheeta Marjery ${ }^{2}$, Frank Boateng ${ }^{3}$ \\ ${ }^{1}$ Business Development Manager, AECI Process and Water, West Africa \\ ${ }^{2}$ Principal, Sree Pashmi Institute of Management, India \\ ${ }^{3}$ Ag. Head, Management Studies Department, UMAT, Ghana
}

\begin{abstract}
This article examines the potentials of an appropriate technology with which the Ghana Agribusiness industry can leverage to boost the living conditions of the industry dependent people, increase the sector's contribution to GDP, and equip local firms with resources to stand the international competition and to offer multinational firms information required during their globalization endeavours. This will be strategic to maximise the opportunities and manage constraints. Moreover, many business constraints exist. Some are poor technological infrastructure, institutional voids, bribery, corruption, bureaucracy, and poorly trained human capital. There was a critical examination of extant studies by several scholars and researchers related to the study's objective. The review's primary focus is to establish strong conceptual, theoretical, and empirical support for this study. These included segments that dealt with the conceptual framework review of competitive advantage and theoretical reviews of the Network Theory. Structured as the third segment is the empirical review. This entails an in-depth review of extant studies related to the three-pronged objectives, with the aim of either rejecting or accepting the underlying framework in such studies. Thematic analysis was employed to analyze the primary data collected via focus group discussion and in-depth interviews. In-depth examination of participants' responses revealed that though the majority (18), 82\% of the participants indicated the adoption of technology in the workplace, whiles a few suggested partial or near adoptions.
\end{abstract}

Keywords: Agribusiness industry, Business model innovation, Constraints, Emerging market, Opportunities, Technology.

\section{Introduction}

Critical evaluation of scholarly works on the influential role of technology in emerging markets reveals that researchers and scholars are divided in their conception of technology and its potential in an emerging market.

While some scholars associated successful entry into an emerging market with the adoption of cutting-edge technology [1], others felt weak institutions in the emerging market economy could translate the myriads of opportunities into an unprofitable venture [2].

\footnotetext{
Received: 30.06.2021

Accepted: 08.02.2022

Published on: 28.02.2022
}

Deepening the gap in understanding, some scholars [3] claimed that an uncooperative or ill-structured ecosystem (upstream and downstream environment of the business different from institutional void) within which a business is embedded could seriously impact any success made in technological frontiers.

A closer study of the theories and concepts underscoring the facilitating influence of technological innovation by a firm into the emerging market has been seriously criticized by some scholars [3] as needing modification 
given the ever-changing terrain of technological frontier and emerging market.

In effect, a corporation involved in Agribusiness with mechanized farming tools in Ghana will only achieve a competitive edge and create value in the industry if other actors such as lawmakers, land administrators, customers, neighbours, are cooperative, possesses the appropriate infrastructure and technical knowhow and overcome obstacles to the use of such mechanized farming tools or innovation. This means, the firm will not only confront the challenges of adopting modern technology, both upstream (suppliers and lawmakers) and downstream (partners), will also face challenges in technology adoption.

The purpose of the study is to conduct an empirical investigation into the important role of technology in a value-driven business process design for an emerging market. The study will discover how technologies can be employed to leverage the booming business opportunities offered by phenomenally growing emerging markets.

\section{Conceptual Framework}

The concepts which underpinned the study included competitive advantage, business model innovation and Technological innovation.

\section{Concept of Competitive Advantage}

An essential component of the successful establishment of value chain business in an emerging market is a competitive advantage. This revealed fierce competition among businesses due to the revolutionary trend of technology and globalization. Hence firms must make a concerted effort at building and maintaining requisite skills and competencies and exhibit dynamism in adapting to the new environment [4], as well as meeting the fleeting demands of customers, values, and processes [5] observed that challenges associated with competition and customer needs and tumultuous business environment can be successfully completed with the application of the conceptual framework of competitive advantage. [6] however, asserted that due to a plethora of confusing information, a strategic manager disentangles the knotty gaps, the dichotomy of opinion, and ambiguity surrounding competitive edge to orchestrate his exploiting all avenues to gain a competitive edge in an emerging market. This notion urges the review of the concept of a competitive edge.

[6] provides a succinct description of what influences competitive advantage in his notable work. The description provides insight and captures the complexity regarding the competitive advantage and the study's overall objective. [7] conceives competitive advantage and the resultant improved organizational performance as representative of the adaptive ability of an organization to its environment, underscoring the point that a business organization that succeeds in adapting to the environment it operates should be capable of matching its strength with the numerous opportunities within its environment including emerging market.

\section{Concept of Business Model Innovation}

This type of innovation is quite different from technological innovation. However, it is complementary to the 4P's of technological innovation [8]. Companies and enterprises have always followed the principle of business model because they are known to have a service or product, provide consumers with the product or service, and collect financial proceeds and profit on transactions. Business management is considered by several scholars and experts [9] as a veritable means of catalyzing experimentation and innovation associated with launching a new product or entering a new market.

Building on the works of [10], conceptualize business model innovation to underscore a situation where alternative business models can be achieved to improve the dynamism associated with a business operation. Such 
dynamism will necessitate continuous reconfiguring, fine-tuning, and refining various framework. Depicted in Figure 1 is the adapted elements within the business model innovation

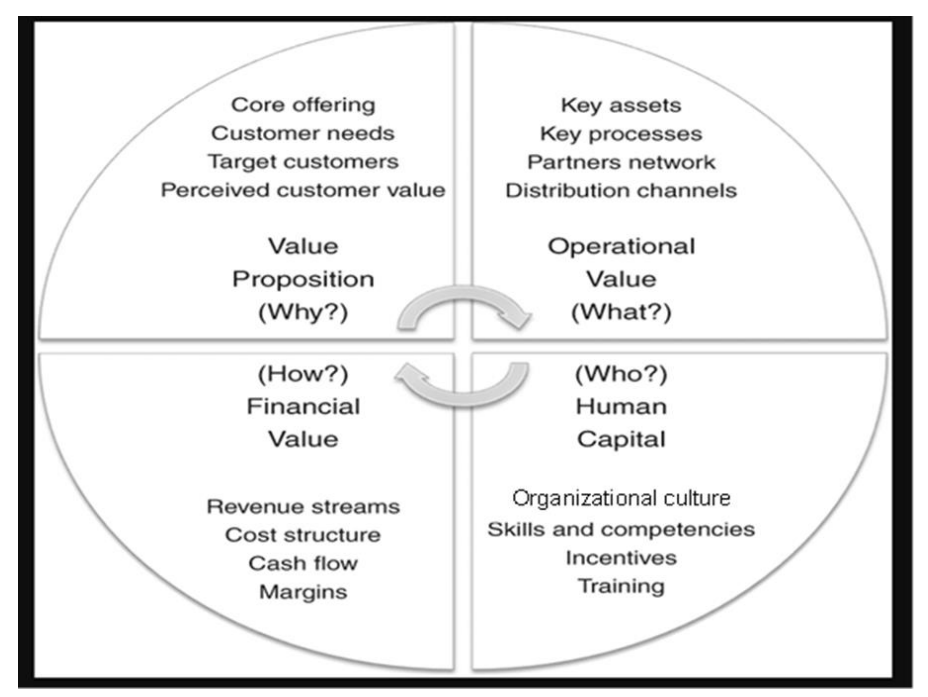

Figure 1. A conceptual framework for Business Model Innovation

Source: Adapted from Ramdani et al. (2019)

In a nutshell, building model innovation, as illustrated in this study, focuses on alternative business model innovation, an offshoot of the previous business model, and a complementary framework to technological innovation. As depicted in Figure 1, building model innovation can fast-track the introduction and sustenance of a new business enterprise in an emerging market.

\section{Concept of Technological Innovation}

Underscoring the nature of innovation, [11] provided a classic concept of technological innovation focused on fast-tracking exploitation of an emerging market by a new business organization. The focus of innovation in this sense is on technology [11]. Initially, Schumpeter's attention was on the tangible aspect of innovation, where a steelmaking entrepreneur gains entry or exploits the emerging market through an innovative approach in production processes. The entrepreneur destroys old structures and creates new ones to legitimize its presence in the emerging market through research and development (R\&D).
[12] discussed the relationship between technological and non-technological factors that can fast track generation. They predicted that the implementation of novel innovation is often lacking. [13] asserted that several innovative activities currently exist that cannot be quantified or measured using the current measurement instruments. Likewise, [14] argues that how several scholars and researchers "conceptualize, define, operationalize, and analyze 'innovation' is rooted in the past, leaving us less able to grapple with other less visible forms of innovation" (p. 11).

Hence, [15] employed a graphic and compelling term "dark innovation" far better than the common term "hidden innovation" to underscore several innovative activities that "has been ignored or are essentially 'invisible' in terms of conventional indicators" (p. 11, 434). $[14,16]$ highlighted some dark innovations as involving innovations based on design, user-related innovation, software, branding, and other intangible investment within the emerging markets such as social innovation. Critical evaluation of [14] submission necessitates defining, 
conceptualizing, and filling the literature gap regarding "dark innovation" in connection with technological innovation.

To fill the gap regarding "dark innovation" in the scope of technological innovation, especially within the framework of an emerging economy, several studies [17] have highlighted the evolving nature of technological innovation and its application within the business sector. For example, [17] posited that technological innovation is very applicable within the sphere of industries or business sectors with less R\&D orientation, such as those with low-technology manufacturing, services, organizational, and marketing innovations.

Technological innovation is thus conceived, according to [17], as involving intangible aspects. Hence, [17] defined this form of technological innovation as involving "implementation of a new or significantly improved product (good or service), or process, a new marketing method or a new organizational method in business practices... or external relations" (p. 46). [17] indicated that this is the way new businesses interested in exploiting emerging markets establish their presence, economic outcomes, and performance. In this sense, the newly implemented approaches, techniques, and methods lead to the accumulation of knowledge to facilitate better performance and financial outcomes in the new terrain.

\section{Theoretical Framework}

There are several theories on using technology to create value, improve productivity, and maintain continuity of competitive advantage for an agribusiness firm venturing into an emerging market [18]. However, Network theory will be reviewed as the undergirding framework for the proposed study.

\section{Network Theory}

As an offshoot of U-Model, Network Theory considers a firm's entry into emerging markets from the perspective of interdependent partners [18]. The proponent of network theory argues that due to the complex interactions within an emerging market, it is difficult for firms to follow the sequential or incremental steps espoused by the U-model theory. Instead, prospective firms rely on resources from partners within the sector and market. [18] refer to this network as an ecosystem. The diagram in Figure 2 vividly portrays the opportunities and constraints that a prospective firm may experience when entering into an emerging market comprising several upstream and downstream partners.

A closer study of figure 2 shows that most of the literature on network theory often focuses on the first quadrant by the left with low external challenges.

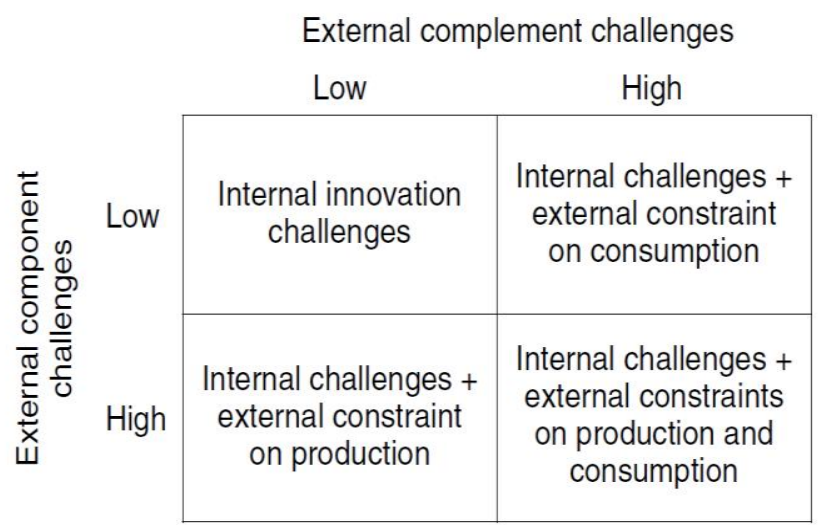

Figure 2. Impact of ecosystem challenges on a prospective investor

Source: Adner and Kapoor (2009) 
This implies that as soon as the firm overcomes its internal challenges, it can successfully enter into the merging market. However, the remaining three quadrants reveal high external component challenges and internal challenges to overcome before the firm can enter the emerging market.

\section{The Implication for the Proposed Study}

The theory underpins the focus of the study because it underscores the gap in the literature concerning the constraints a prospective firm could encounter before successful integration into the market. Initially, it was conceived that as soon as a firm overcomes the internal challenges of integrating technology as a source of value creation, it would have attained a competitive advantage. However, in $[19,20]$ studies, external challenges arising from interdependent partners concerning the use of appropriate technology could seriously impact any success a firm could attain even if it has overcome internal challenges within its establishment. For example, a plastic corporation only needs to device appropriate technology to produce its plastic. Suppliers, customers, and others need not worry about complementing the technology employed in the production of plastics. However, a firm such as a hotel would need its upstream (suppliers) and downstream (customers) partners to cooperate with the technologies adopted for operations; otherwise, the firm may be out of business [20].

However, the nature of challenges to be confronted by individual firms entering into emerging markets differs. To use cutting-edge technology for value creation and maintenance of a competitive edge, a firm must carefully consider the best form of technology during process design. Hence, there is a need to fill the lacuna in understanding a firm interested in agribusiness in an emerging market economy.

\section{Literature Review}

Emerging markets are very competitive and are constantly growing with new trends and technology alongside several [21]. This underscores the fact that an agribusiness investor should calculate the cost by making a novel decision on ensuring competitive advantage, increased productivity, and continuity. All of which can be done by adopting appropriate technology [22].

The review argues that there are several constraints leveled against the instrumentality of technology in the process of designing valuedriven business within an emerging market [23]. Despite these constraints, it remains a potent variable and an inextricable element for successful business ventures in the emerging market. Conceptual and theoretical frameworks were synthesized to determine whether several theories underpinning the influence of technological innovation need modification given the ever-changing terrain of technological breakthroughs.

In fulfilling the study's primary objective, the researcher seeks to retrieve firsthand information regarding African society's socioeconomic and day-to-day realities. Hence, the review contended that most studies on the facilitation of value-driven business within the emerging market environment are secondary data. It has limited studies employing primary data or empirical investigation as an approach to research.

The findings of several studies [23] revealed certain limiting factors associated with emerging markets. These include digital infrastructural constraints, shifting sand of tax law on digital technology, poor digital security, and localization. This study argues that rigorous interrogation of extant studies and empirical findings will help distill relevant information. This information helps develop the innovative approach that can override these hurdles and create a value chain and thriving enterprise in Agribusiness if used by investors.

\section{Empirical Review}

This section of the study critically examined extant literature about the study's objectives. 
Studies were examined chronologically to isolate gaps in the literature and empirical solidrical support for the present study's focus. The review in this section examined relevant studies connected with several market opportunities within emerging markets ready for exploitation by an investor or business organization alongside constraints that may limit such exploitation. The review entails rigorous interrogation of extant literature in connection with the facilitation of business operation through the application of novel technologies to meet the tenet of the 4P's of technological innovation and business model innovation in mitigating the constraints associated with value creation and maximization of profit. The empirical review also touched on the inestimable benefit of technology-savvy businesses over the traditional businesses in terms of a competitive edge as well as profit margin. Another aspect of technology-savvy businesses was also examined, especially about Corporate Social Responsibility, which is considered an essential factor in competitive advantage within an emerging market [24].

\section{The Employment of Appropriate Technology for Value Creation}

The findings of several studies basing their conception on technological innovation [25], business model innovation, and competitive advantage see novel technology and the latest breakthrough in the technological frontier as closely linked and inseparable to improved productivity and sustained competitive advantage. For example, [26] indicated that technology such as big data solutions could fast track productivity within the agricultural setting, [26] posited that with an innovative approach to product and service design through statistical software and technology such as big data statistical solution [26].

However, several other scholars and researchers [27] see the matter differently from the concept of economic theory. This school of thought focused its attention on the several limiting factors constraining technology integration in business operations within the emerging market [28]. They are concerned with the specificity regarding each technology. By specificity, they mean specific technology could be applicable in one context and nonapplicable in others [29]. Likewise, the cost and maintenance of such technology could be intimidating or counter-productive if they are inappropriate to the chosen area of application. Considering the dichotomy of opinion among scholars, technology's facilitation of new investors or prospective businesses in an emerging market is not automatic or by default. The prospective investor and business organization must approach selecting appropriate technology innovatively, considering what works best, the overhead cost of using such technology, the overall cost of production when such technology is used, and the level of profitability during the integration of such technology. This means, within the context of agribusiness, it is pertinent that a prospective investor critically examines available technologies under the probing light of the four elements of business model innovation to determine whether such implementation will yield a higher profit margin or mar the profitability of the business venture.

The prospective investor also needs to examine the cost of getting such technology overseas compared to locally made ones. This is part of the resourcefulness prospective investors need, especially the ability to use local raw material for production to minimize cost and maximize profit [30].

The new business organization should also consider the implication of political instability in several emerging economies due to fledgling democracy tainted with high-level corruption. Forestalling such constraint, [3] felt that with the presence of an enabling ecosystem, a prospective business organization could succeed, especially in developing a product or 
service with technology partners, and customers could readily adopt and access when needed. However, a gap remains on how a prospective investor could merge business model innovation with technological innovation within the sphere of agribusiness, knowing the fluidity and unstable nature of technological innovation making obsolete an appropriate technology of today within a short while [28]. Moreover, within the context of agribusiness, the success of farmers is directly proportional to the success of investors [31]. Hence, unpredictable weather conditions could also be a limiting factor in technology implementation since floods, pests, and other natural disasters could mar the successes achieved so far.

\section{Methodology}

An inestimable aspect of the research project is the systematic approach to collecting relevant information, to fill the lacuna in literature, and adequately addressing research problems [32]. To garner rich data culminating in wellvalidated and reliable findings, the method adopted should be unbiased and rigorous [33].

A critical examination of the theories undergirding the present study, comprising Network, Theory, necessitates adopting interpretivism as the research philosophy. The theoretical perspective of interpretivism revolves around making sense of subjects' subjective intention and varied meanings within a context or universe of a study, without the imposition of prior analytic groupings [34].

Interpretivism entails concerted effort by the researcher at understanding the world from the viewpoint and firsthand information retrieved from the study's participants. The findings of several studies [35] reveal that there are threepronged approaches to research projects, namely: 1) quantitative paradigm, 2) qualitative paradigm, and 3) mixed-methods combining qualitative and quantitative research paradigms. After carefully examining the three forms of research paradigms, the qualitative research paradigm is adopted for this study, given the research philosophy guiding the study. [36] Indicated that qualitativehelpfuligm helps conduct an in-depth investigation concerning the subject matter of research and enhance researchers' ability to employ case studies or multiple case studies to furnish a narrative or descriptive account of practice or design.

Qualitative research design is very suitable for the study because it facilitates efforts to gain a deeper understanding of the relevant facets for collecting well-validated information based on first-hand experience of participants void of manipulation by the researcher. [37] Indicated that, like quantitative research design, qualitative studies can also be generalized to a more significant population.

Relevant data were elicited from 22 participants. An in-depth interview was conducted with 10 management and nonmanagement staff participants. To moderate Focus Group Discussion, 12 participants were divided into three groups comprising four participants to distill relevant information related to the focus of the study.

Process managers and other professionals such as those in the R\&D and Marketing Department were interviewed. I consulted relevant sources, including peer-reviewed sources, to bridge the gaps identified at the outset of the study and retrieve valuable information to aid the resolution of research problems. Due to their successes in their respective businesses, they possess a wealth of experience in transcending limiting factors such as unpredictable market forces, weak institutions, and difficulty associated with selecting the most appropriate technology. Participants comprised 12 men and 10 women.

The majority (14) of the participants have over 8 years of working experience, 4 had over 12 years of working experience, while the remaining 4 had less than 8 years of working experience. This clearly demonstrated that this group of participants could provide rich data as far as the focus of this study is concerned. 


\section{Research Instruments/Measurements}

The proposed study will employ two powerful instruments for data collection. Structure interview guide and focus group discussions will be relevant in collecting pertinent information from participants and individual cases. Suggesting appropriate means of employing a structured interview guide, [38] indicated that an interview guide should be designed to elicit the best possible information from the participants to the end of enriching the study's findings. This means much attention will be given to the content of the interview guide.

The guide will be structured to touch on relevant issues that would fast track resolution of the three research questions. The focus will elicit important information regarding the topic under research. It will entail open-ended questions probing how firms, primarily locallyowned ones, can exploit the numerous opportunities in an emerging market using appropriate technology. The guide will also touch on how these firms overcome constraints that could have mitigated entry into emerging markets or continuity of value-creation and competitive edge.

[39] posited that the Focus Group Interview (FGI) is a highly result-oriented and credible instrument for data collection in a qualitative research approach. [39] Defined Focus Group Interview is a technique where participants are drawn from various backgrounds within the sphere of the phenomenon under study to discuss and relieve complex personal experiences, perceptions, beliefs, attitudes, and perceptions via a moderated or coordinated interaction. [40] succinctly stated that it creates an avenue where the researcher co-creates meaning with participants on the given subject, phenomenon, or topic under consideration.

As a result, stakeholders in the agribusiness would be selected for the study and interviewed and participate in focus group discussions alongside other staff within the firm. This will ensure the co-creation of meanings regarding the focus of the study.

\section{Techniques for Data analysis}

Thematic analysis will be employed for analyzing primary data collected via focus group discussion and in-depth interviews. According to [41], thematic analysis involves immersion in textual data with the sole aim of deciphering and identifying emerging trends, patterns, and themes for analysis.

In order to gather credible and reliable data, all interview and focus group discussions will be recorded with a digital recorder based on the consent of participants. Recorded interviews and discussions will be played afterward and manually transcribed to identify trends, patterns, and themes relevant to the resolution of research problems.

The themes generated will be used as a significant reference point for the analysis. In some instances, verbatim quotations from transcribed data will be reproduced to enable readers to feel the study's pulse and deepen knowledge on strategic management associated with appropriate technology, value-creation, and emerging market [23, 42].

There are various approaches to conducting thematic analysis, but the most common form followed is a six-step process:

1. Familiarization

2. Coding

3. Generating themes

4. Reviewing themes

5. Defining and naming themes

6. Writing up

\section{Results}

The primary focus of this chapter is to unravel relevant insight, trends, patterns, and themes from the elicited data for the study. In effect, this section deals with findings or outcomes of the study within the context of the transcribed data retrieved from the field. The overarching objective of the study is to conduct an empirical investigation into the critical role 
of technology in a value-driven business process design for an emerging market.

\section{Extracts and Analysis}

\section{Research Question \# 2}

In what ways can appropriate technologies be utilized during product and service design stages to mitigate these constraints and maximize the bottom line of value creation at an acceptable profit?

This question is directed towards ascertaining what appropriate technology within the context of agribusiness activities is. It is also envisaged that relevant information will be elicited regarding the processes of product and service design as a lever to mitigate the identified constraints associated with agribusiness operation within Ghana.

Adequately answering this research question requires in-depth information regarding the various technology business leaders within the Agribusiness sector in Ghana are using to maximize profit. This study segment will provide ample insight into what business leaders consider the most crucial strategy in outpacing limitations associated with the emerging market. The analysis will unearth relevant information concerning how business leaders and investors succeed in launching new products that meet the customer's taste due to the carefully orchestrated process and product design. Such a product is affordable meets customers' imagined value with minimal cost of production.

Participants' responses are presented below regarding appropriate technology to fast-track the creation of value within the agribusiness sector in Ghana. Responses are summarized in the excerpt below. The effort has been made to adequately represent participants' knowledge, understanding, and perspectives in the excerpts and analysis.

In response to the question that could be termed appropriate technology in agribusiness, participants' responses revealed that the majority (18) are fully aware of what constitutes appropriate technology. While some are already using it, others are yet to integrate it into their business operations fully. Participants' responses are summarized in the excerpts below: In my perspective, appropriate technology is any type of technology developed to transcend constraints associated with an agribusiness organization's production and economic growth.

Management staff with 9 years of working experience.

With my experience in agribusiness, I think appropriate technology should not only be concerned about boosting the economic advantage of an organization, but designers of such technology should also be concerned about the welfare of the people around whether the technology will not destroy natural habitat. This reminds me of some pesticides or machinery that could harm employees and customers alike.

Management staff with 14 years of working experience.

Appropriate technology is not only about the organization; it is also about the community. The technology should be helpful in the resolution of recurring problems limiting growth in the community, especially if it is an agriculturally based society.

Gleaned from Focus Group No. 3.

As captured in the excerpts above, a perusal of participants' responses revealed that appropriate technology is created out of necessity borne from ingenuity. The right technology becomes relevant when it resolves a recurring or suddenly developed constraint or challenge while carrying out agribusiness operations. From the excerpt, it can also be inferred that appropriate technology could also be imported or produced by an entity outside the community in need of such technology.

A closer study of the excerpts revealed that appropriate technology should be carefully designed to suit the community's socioeconomic needs. In other words, it should 
not only help boost their livelihood, but it should also facilitate responsible living for the sustainability of the immediate environment. For the exam, specification equipment could be beneficial but harmful in the long run. Submission of the participants is consistent with the findings of several studies. For example, [28] indicated that an investor could fine-tune his process design so that an appropriate technology or novel approach to production is adopted as a way of creating a competitive advantage. According to [28], developing proper technology will fast-track production since the community needs such products and is limited by their inability to decipher the best way of getting them.

Development of appropriate technology, environmentally sustainable with no harm to the community, according to [43], will ensure continuity of business operation since the technology is harmless, will fast track business operation, and increase patronage. Inappropriate technology will incur the wrath of the community and the government of Ghana, culminating in the closure of such business operations or defined as illegal.

Due to their wealth of experience he agribusiness, the majority, $89 \%$ of the participants, was able to outline what they consider an effective strategy in adopting appropriate technology. Their responses are sentialptured in the excerpts below:

The firm's strategy considers the location where the business is located. For example, in Ghana, a strategy involving the use of fourth industrial revolution (4IR) technology such as artificial intelligence, Big Analytics, Advanced processes, or Augmented reality/wearables will be considered ineffective. Rather strategy employs materials readily available in Ghana and can be easily controlled by indigenes or employees.

Management staff in the $R \& D$ department with 8 years of working experience.

In developing an effective strategy, we first researched the recurring need that can be filled upon discovering the need, intense dialogue, and consultation of those within the sector. This helps us retrieve valuable information from those with firsthand details to convert such data into the formulation of appropriate technology to resolve the problem.

Non-management staff with six years of working experience in the R\&D department.

\section{Discussions}

The excerpts above revealed that strategy in adopting appropriate technology and process design involves thorough research, consultation, and cognition of the environment within which the technology is to be adopted. Due to several limiting factors, especially low technological skills, the strategy should be simple, reproducible, and easy to operate. A complex or complicated approach to adopting technology could create difficult technology to maintain, support, or use.

Hence, as reflected in the excerpts, intelligent business leaders look for a realistic and straightforward strategy that will ensure a competitive edge and ensure continuity of the business operation. Such a process should be reproducible, employees can be trained, and partners and customers will be prone to accept it. Consultation with those experiencing the difficulty also paves the best strategy for adopting appropriate technology to boost competitive edge and value creation.

The findings of the study are consistent with the result of a study by [43] that whatever strategy is orchestrated, it should be suitable for the environment within which the business is located, easy to manage, prone to boosting competitive edge, and relevant in developing requisite skills or competencies in employees. Study in [44] tally with the result of this study, which intimated that strategy should be borne out of thorough consultation with those having firsthand information regarding the difficulty or constraints. The talk will also include possible recommendations by those experiencing the problem on how it can be resolved so that the 
development of appropriate technology by an investor will result in a competitive edge and continuity of the business operation since it will be a panacea to the problems or constraints associated with the sector.

Results of the study also coincide with the U-model, which indicated that strategy should be carefully developed through a pragmatic approach to ensure entry into an emerging market. The process entails four steps which respondents have mentioned. These include 1) acquisition of knowledge of the given market, 2) big commitment vital to decision making, 3) planned activities structured into stages, and 4) change or adapt to the market situation. This tally with the study result because consultation, strategy development, and adaptation to the market situation via the development of appropriate technology boost productivity and continuity.

One of the management staff with 10 years of working experience provided a practical example of a strategic move to adopt appropriate technology to fast-track entry into agribusiness. She stated:

We are interested in starting an agribusiness involved in the production of tomato paste. The arable land for the tomato plants, based on consultation, reveals that it is often affected by drought. We strategize to overcome the constraint. We developed an irrigation system with a touch of ingenuity. Smart sensor measuring the temperature of the ground was advantageous. As soon as this sensor detects a rise in temperature beyond a certain threshold, it triggers the pumping machine, allowing for irrigation. However, as soon as the temperature drops below a certain threshold, the pumping engine starts to stop pumping water. Hence, whether we are at the farm or not, there is constant water flow without flooding or lack of water.

Management staff with 11 years of working experience.
We process the coconut tree for its oil and water, thus requiring plucking a large quantity of the coconut fruit. Climbing the tree is very tedious; as a result, many of the laborers either charge too much or refrain from climbing. We got in touch with an engineer that designed and build an escalator/power ladder lift. All the raw material was procured in Ghana. With these power ladders, the difficulty of plucking the coconut was resolved, culminating in increased production and profit.

Gleaned from Focus Group 2.

Recently we opened a new branch, but we were confronted with drought due to poor weather conditions for growing cotton. As a result, the $R \& D$ department thoroughly investigated soil composition. In collaboration with our partner in Zimbabwe, who faced similar weather conditions and soil type, a drought-tolerant seed was engineered so that the cotton would grow and thrive with optimum yield irrespective of the level of water in the soil.

Management staff with 9 years of working experience.

A closer study of the excerpts above clearly demonstrated a novel approach or strategy to adopting innovative or appropriate technology. In all the instances, ample consultation, thorough observation of market condition, and development of a proper technology to resolve the constraint and ensure continuity in business operation. It is noteworthy that the technology was appropriate in each case because it fits the organizational environment and objectives. In each case, the technology was right because it was harmless to both the user and the environment. It is likewise appropriate because it fills the need of the business organization and eases the laborious work involved in putting on the pump from time to time, as well as climbing coconut trees without any safeguard. 
Table 1. Strategic ways to adopt Technology. Source: Research data

\begin{tabular}{|l|l|}
\hline Strategic ways to use Technology & Frequency of appearing in themes \\
\hline $\begin{array}{l}\text { Conduct in-depth enquiry and consultation so as to } \\
\text { decipher what is the need or what can make for } \\
\text { competitive advantage. }\end{array}$ & 7 \\
\hline $\begin{array}{l}\text { Decide whether to build or develop a technology to } \\
\text { fill the need or will purchase already made } \\
\text { technology }\end{array}$ & 4 \\
\hline $\begin{array}{l}\text { Make sure the strategy is sustainable, reproducible, } \\
\text { easy to maintain and is manufactured or purchased at } \\
\text { a relatively cheaper cost and }\end{array}$ & 8 \\
\hline
\end{tabular}

\section{Conclusion and Implications}

Strategic steps as indicated by participants: 1) Conduct in-depth enquiry and consultation so as to decipher what is the need or what can make for competitive advantage, 2) decide whether to build or develop a technology to fill the need or will purchase already made technology, 3) make sure the strategy is sustainable, reproducible, easy to maintain and is manufactured or purchase at a relatively cheaper cost and 4) be sure to make sure that the strategy suits your organizational culture and overall objective of the firm.

The following was also coded during the data compilation.

Table 2. Relative Benefits of Tech and Non-Tech Companies. Source: Research

\begin{tabular}{|l|l|l|}
\hline \multicolumn{3}{|l|}{ Relative Benefits of companies in an emerging economy (Ghana) } \\
\hline Tech-savvy companies & Traditional companies & For Both \\
\hline 4 & 2 & 2 \\
\hline Fast-tracked competitive Advantage & Low Maintenance cost & Tax holidays \\
\hline Increased productivity & short downtime & Relaxed policies \\
\hline Economies of scale & & \\
\hline Weak entry barriers & & \\
\hline
\end{tabular}

\section{Limitations of Studies}

Limited time and participants' availability due to the covid-19 impacts workers' shifts and outings. This was limited to the Agribusiness industry and hence cannot be generalized to other industries within the emerging market of Ghana.

Also, another empirical study could be conducted utilizing the quantitative approach to the research as this was biased towards qualitative approaches.

Many intended participants declined even after the promise of hiding their identity due to fear of their candid response going public and going against company policies.

\section{Conflict of Interest}

Moreover, no financial and relationship conflicts of interest exist. Therefore, the article is as balanced, objective, and evidence-based as possible.

\section{Acknowledgement}

Admittedly some assistance was received by some people into this manuscript (e.g., technically, writing and reading and editing service, general). However, the help does not mark authorship; hence there were no acknowledgments as co-authors. 


\section{References}

[1] Amankwah-Amoah et al.2020; (2014). Solar Energy in Sub-Saharan Africa: The Challenges and Opportunities of Technological Leapfrogging. Thunderbird International Business Review. 57. 10.1002/tie.21677.

https://www.researchgate.net/publication/268983770 _Solar_Energy_in_Sub-

Saharan_Africa_The_Challenges_and_Opportunities _of_Technological_Leapfrogging.

[2] Hoepner, A.G.F., Li, Q., Muzanenhamo, (2020) Penelope, Corporate Social Irresponsibility of African Firms Across the Continent: Does Leave the Path of Social Responsibility Hurt Shareholder Value? https://ssrn.com/abstract=3245952 or http://dx.doi.org/10.2139/ssrn.3245952.

[3] Adner, R., \& Kapoor, R. (2010). Value Creation in Innovation Ecosystems: How the Structure of Technological Interdependence Affects Firm Performance in New Technology Generations. Strategic Management Journal, 31 (3), 306-333. http://dx.doi.org/10.1002/smj.821.

[4] Balogun, J., \& Johnson, G. (2004). Organizational Restructuring and Middle Manager Sensemaking. The Academy of Management Journal, 47(4), 523-549. https://doi.org/10.2307/20159600.

[5] Sołoducho-Pelc, Letycja. (2014). Competitive Advantage: The Courage in Formulating Objectives and Expansiveness of a Strategy. Procedia - Social and Behavioral Sciences. 150. 271280.10.1016/j.sbspro.2014.09.058.

https://www.researchgate.net/publication/272392001 _Competitive_Advantage_The_Courage_in_Formul ating_Objectives_and_Expansiveness_of_a_Strategy

[6] Hakravarthy, B.S. (1986) Measuring Strategic Performance. Strategic Management Journal, 7,437458. https://doi.org/10.1002/smj.4250070505.

[7] Ramdani, B., Binsaif, A., Boukrami, E. (2019).

Business model innovation: a review and research agenda. New England Journal of Entrepreneurship. https://www.semanticscholar.org/paper/Businessmodel-innovation \%3A-a-review-and-researchRamdani-
Binsaif/618cf13429b7be3ab0c7346bd32ccf2541cb1 d3f.

[8] Ramdani B., Binsaif A., Boukrami E., Guermat C. (2020). Business models innovation in investment banks: a resilience perspective. Asia Pacific Journal of Management. 10.1007/s10490-020-09723-z. https://www.researchgate.net/publication/342245568 _Business_models_innovation_in_investment_banks _a_resilience_perspective\#pf8.

[9] Bstieler, L., Gruen, T., Akdeniz, B., Brick, D., Du, S., Guo, L., Khanlari, M., McIllroy, J., O’Hern, M., \& Yalcinkaya, G. (2018). Emerging Research Themes in Innovation and New Product Development: Insights from the 2017 PDMA-UNH Doctoral Consortium. Journal of Product Innovation Management, 35(3), 300-307. https://doi.org/10.1111/jpim.12447.

[10]Al-Debei, M. M., \& Avison, D. (2010). Developing a unified framework of the business model concept. European Journal of Information Systems, 19(3), 359-376. https://doi.org/10.1057/ejis.2010.21.

[11] Garcia, R., \& Calantone, R. (2002). A literature review is a critical look at technological innovation typology and innovativeness terminology. Journal of Product Innovation Management, 19(2), 110-132. https://doi.org/10.1111/1540-5885.1920110.

[12]Diaconu, Mihaela. (2011). Technological Innovation: Concept, Process, Typology, and Implications in the Economy. Theoretical and Applied Economics. XVIII (2011). 127-144. https://www.researchgate.net/publication/227364059 _Technological_Innovation_Concept_Process_Typo logy_and_Implications_in_the_Economy.

[13]Fagerberg, Jan. (2018). Innovation, Economic Development, and Policy. 10.4337/9781788110266. https://www.researchgate.net/publication/324891483 _Innovation_Economic_Development_and_Policy. [14]Fagerberg, J. (2013). Innovation - a New Guide. https://www.semanticscholar.org/paper/Innovationa-New-Guide-

Fagerberg/338e301677b9e2379449901cabc4c1ba8f $90 f 939$.

[15] José A. Pedraza-Rodríguez, Peter Bolcha, Luna Santos-Roldán. (2021) from strategies to innovation: 
an empirical study from Spain. Technology Analysis \& Strategic Management 33:2, pages 134-147.

[16] OECD/Eurostat (2018), Oslo Manual 2018: Guidelines for Collecting, Reporting and Using Data on Innovation, 4th Edition, The Measurement of Scientific, Technological and Innovation Activities, OECD Publishing, Paris/Eurostat, Luxembourg,

https://doi.org/10.1787/9789264304604-en.

[17]Chang, Victor, Wills, Gary and Baudier, Patricia (2021) Impacts and investigations of disruptive technologies for Industry 4.0. Technological Forecasting and Social Change. https://eprints.soton.ac.uk/cgi/request_doc?docid=22 34362.

[18] Mohibul, A.(2008)Internationalization Process of SME: Strategies and Methods https://www.divaportal.org/smash/get/diva2:121500/FULLTEXT01.p df.

[19] Sharma, D., \& Blomstermo, A., 2003. "The internationalization process of Born Globals: A network view," International Business Review, Vol. 12, pp. 739-753.

[20] Adner, R., \& Kapoor, R. (2009). Value Creation in Innovation Ecosystems: How the Structure of Technological Interdependence Affects Firm Performance in New Technology Generations (SSRN Scholarly Paper ID 1353582). Social Science Research Network. https://doi.org/10.2139/ssrn.1353582.

[21]Bstieler, L., Gruen, T., Akdeniz, B., Brick, D., Du, S., Guo, L., Khanlari, M., McIllroy, J., O’Hern, M., \& Yalcinkaya, G. (2018). Emerging Research Themes in Innovation and New Product Development: Insights from the 2017 PDMA-UNH Doctoral Consortium. Journal of Product Innovation Management, $\quad 35(3), \quad 300-307$. https://doi.org/10.1111/jpim.12447.

[22] Chowdhury, S., Azziz-Baumgartner, E., Kile, J. C., Hoque, Md. A., Rahman, M. Z., Hossain, Md. E., Ghosh, P. K., Ahmed, S. S. U., Kennedy, E. D., Sturm-Ramirez, K., \& Gurley, E. S. (2020). Association of Biosecurity and Hygiene Practices with Environmental Contamination with Influenza A Viruses in Live Bird Markets, Bangladesh.
Emerging Infectious Diseases, 26(9), 2087-2096. https://doi.org/10.3201/eid2609.191029.

[23] World Bank Group (2017). Leapfrogging: the key to Africa's development? From constraints to investment opportunities. Retrieved on March 2, 2020, from http://documents.worldbank.org/curated/en/1215815 05973379739/pdf/Leapfrogging-the-key-to-Africasdevelopment-from-constraints-to-investmentopportunities.pdf.

[24]Li, Shaomin, et al. "Corporate Social Responsibility in Emerging Markets: The Importance of the Governance Environment." MIR: Management International Review, vol. 50, no. 5, 2010, pp. 635-654. JSTOR, www.jstor.org/stable/41426815 Accessed 15 July 2021.

[25]Fagerberg, J., Martin, B. R., \& Andersen, E. S. (2013). Innovation Studies: Evolution and Future Challenges. Oxford University Press.

[26] World Bank. 2015. Big Data Solutions: Innovative Approaches to Overcoming Agricultural Challenges in Developing Nations by Harnessing the Power of Analytics. World Bank, Washington, DC. (C) World Bank. https://openknowledge.worldbank.org/handle/10986 /26436 License: CC BY 3.0 IGO

[27]Ball, V.E., Butault, J.P., Carlos, S.J.M. and Mora, R. (2010). Productivity and international competitiveness of agriculture in the European Union and the United States, Agricultural Economics 41, 611-627.

[28] Amankwah-Amoah, J., Debrah, Y. A., Yu, W., Adomako, S., \& Danso, A. (2020). Technology strategies in emerging economies: emerging issues, challenges, and new research. Elsevier B. $V$ : Technological Forecasting and Social Change, 2 (1), p. 1.

[29] Adner, R., \& Kapoor, R. (2009). Value Creation in Innovation Ecosystems: How the Structure of Technological Interdependence Affects Firm Performance in New Technology Generations (SSRN Scholarly Paper ID 1353582). Social Science Research Network.

https://doi.org/10.2139/ssrn.1353582. 
[30]Boso, N., Adeleye, I., Ibeh, K., \& Chizema, A. (2019). The internalization of African firms: opportunities, challenges, and risks. Thunderbird International Business Review, 61 (1), pp. 5-12.

[31] Abramovitz, M. 1956. Resource and output trends in the United States since 1870. American Economic Review, Papers, and Proceedings, 46 May: 5-23.

https://www.fao.org/3/x9447e/x9447e03.htm\#TopO fPage.

[32] Kothari (2004). Research methodology: Methods and Techniques. New Delhi; New age international $(P) \quad$ Limited, publisher http://www.sciepub.com/reference/233432.

[33]Kumar, R. (2011) Research Methodology: A Step-by-Step Guide for Beginners. 3rd Edition. Sage, New Delhi. https://www.scirp.org/(S(oyulxb452alnt1aej1nfow45 ))/reference/ReferencesPapers.aspx?ReferenceID=1 971596.

[34]Bonache, J. and Festing, M. (2020) 'Research paradigms in international human resource management: An epistemological systematization of the field,' German Journal of Human Resource Management, 34(2), pp. 99-123. Doi: $10.1177 / 2397002220909780$.

[35] Creswell, JW. 2014. Research Design: Qualitative, Quantitative, and Mixed Methods Approaches. Thousand Oaks: Sage Publications. https://www.scirp.org/(S(i43dyn45teexjx455qlt3d2q ))/reference/ReferencesPapers.aspx?ReferenceID =1 964849 .

[36] Creswell, JW. \& Poth, CN. (2018) Qualitative Inquiry and Research Design Choosing among Five Approaches. 4th Edition, Sage Publications, Inc., Thousand Oaks.

https://www.scirp.org/(S(lz5mqp453edsnp55rrgjct55

))/reference/reference

papers.aspx?referenceid=2155979.

[37] Yin, R.K. (2016). Qualitative Research from Start to Finish, Second Edition. New York: The Guilford Press. ISBN: 978-1-4625-1797-8. 386 pp. https://doi.org/10.1111/fcsr.12144.

[38]Lohfeld, W. (2008). Review: Sharlene HesseBiber \&amp; Patricia Leavy (2006). The Practice of Qualitative Research. Forum Qualitative
Sozialforschung Forum: Qualitative Social Research, 9(1). https://doi.org/10.17169/fqs-9.1.363. [39] Nyumba, T., Wilson, K., Derrick, C., \& Mukherjee, N., (2018) The use of focus group discussion methodology: Insights from two decades of application in conservation. Methods in Ecology and Evolution, 9(1), pp. 20-32.

[40] Overlien C, Aronsson K and Hyden M (2005) The focus group interview as an in-depth method? Young women are talking about sexuality. International Journal of Social Research Methodology $\quad$ 8(4): $\quad 331-344$. https://journals.sagepub.com/doi/pdf/10.1177/00219 09619857098.

[41] Nowell, L.S., Norris, J.M., White, D.E. and Moules, N.J. (2017) Thematic Analysis: Striving to Meet the Trustworthiness Criteria. International Journal of Qualitative Methods, 16, 1-13. https://doi.org/10.1177/1609406917733847.

[42]Boso, N., Adeleye, I., Donbesuur, F., \& Gyensare, M. (2019). Do Entrepreneurs Always Benefit from Business Failure Experience? Journal of Business Research, 98, 370-379. https://doi.org/10.1016/j.jbusres.2018.01.063.

[43] Amankwah-Amoah J., Albert D., (2019), and Samuel A. "Entrepreneurial orientation, environmental sustainability, and new venture performance: Does stakeholder integration matter? "Business Strategy and the Environment 28.1: 7987.

https://onlinelibrary.wiley.com/doi/abs/10.1002/bse. 2191.

[44]Banjo R. (2021), Environmental sustainability engagement of firms: The roles of social capital, resources, and managerial, the entrepreneurial orientation of small and medium enterprises in Vietnam, Business Strategy, and the Environment, 10.1002/bse.2743, 30, 4, (2194-2208). 


\title{
The Effect of Corporate Reputation on the Performance of Corporate Organizations in Developing Countries: Evidence from West Africa
}

\author{
Kingsley Nwagu \\ Department of Management, School of Research, Texila American University
}

\begin{abstract}
This study is carried out to understand the effect of corporate reputation on the performance of corporate organizations in developing countries: evidence from West Africa. The population for this study consists of selected listed multinational companies in Nigeria and Ghana. The data was collected using a structured questionnaire and was measured on an interval scale through the research questionnaire. The statistical tool used to analyze the set variables is multiple regression. It involves the collection, collation, analysis, and interpretation of data for this study. It further incorporated ANOVA to show CSR Practices and their impact on the performance of corporate organizations as explained by the independent variables through the coefficient of determination $R^{2}$. This design is useful and most appropriate in measuring the degree of association between two or more variables. It is also helpful in measuring the effect of independent variables on a dependent variable. As predicted, the study proves that corporate social responsibility practice can be integrated into corporations' business strategy for enhanced performance. Rather than just being beneficial to society, corporate social responsibility can be the value-added opportunity for corporations that engages in responsible actions. The research adds to the existing literature on corporate social responsibility practices and their impact on corporate performance.
\end{abstract}

Keywords: Corporate Social Responsibility, Corporate organization, Philanthropy, Performance, Reputation, West Africa.

\section{Introduction}

The subject of Corporate Social Responsibility (CSR) is critical because businesses have before now had well-defined economic and legal responsibilities [1]. Companies adopted the term CSR as a management framework to address the overbearing social and environmental shackles bedeviling society. This term, known as corporate social responsibility, became relevant. CSR encompassed a perceived responsibility in areas such as environmental concerns, community involvement, corporate governance, employee relations, and other social performance dimensions. Although there is no consensus on the meaning of Corporate Social
Responsibility, the term generally refers to a current commitment by business to behave ethically and contribute to economic development while demonstrating respect for people, communities, the environment, and society at large. In a nutshell, CSR ties the concept of global citizenship with environmental stewardship and sustainable development. Much of the research preceding our understanding of CSR has concentrated on business-society relationships and dynamics in the developed economies and on awareness, determinants, practice, and disclosure of CSR in developing countries. More recently, there has been a sprouting interest in understanding the dynamics and peculiarities of CSR in emerging economies, vis-à-vis uncovering the relationships between 
CSR practices and organizational performance, especially in the context of financial variables such as profitability. [1-6].

\section{Statement of the Problem}

A pre-study review by the author, of information bothering on CSR practice in developing countries reveals there are levels of CSR acceptance in developing countries which constitutes a problem to a synchronized method. First, some business leaders perceive CSR as a mere best practice activity to gain endorsements for political purposes or otherwise. Leaders in this category intermittently give out cash donations. The second category view CSR as an imposed external practice exported by mother companies of the western world. The other set of leaders understands their dual responsibility to make money for their organization and interact ethically with the surrounding community. These crops of leaders understand that practicing CSR is complex and requires organizational resources such as expertise, personnel, time, and money.

The challenging question for leaders in this category is: how do we recover the funds invested through CSR? What is the impact of CSR practice on the company's performance? The shortage of research studies that survey the impact of CSR practices on the performance of business organizations in this part of the world constitutes a problem to both business and society. Some business leaders refrain from their responsibility to the community due to doubts and fear that they may encounter losses as there is no clear understanding of how social responsiveness affects their organization's performance. Consequently, there is a need to undertake a study on this note to provide clear perspectives for business leaders. This present study, therefore, is set out to answer the question below.

\section{The Objective of the Study}

The objective of the study is to examine the impact of corporate social responsibility (CSR) practices on the performance of organizations with evidence from West Africa.

The specific objective is to examine the effect of reputation on the performance of corporate organizations in developing countries.

\section{Research Question}

This study intends to gather extensive understanding to answer the following question:

How does reputation influence the performance of the corporate organization in developing countries?

\section{Statement of Hypothesis}

The following hypothesis was formulated for this study in null form is as follows:

$\mathrm{Ho}_{1}$ : A firm's reputation does not significantly affect the performance of corporate organizations in developing countries.

\section{Literature Review}

\section{Conceptual Framework}

Corporate Social Responsibility (CSR) is an exciting subject in developed nations and in developing countries. There is a growing interest in CSR, with an increasing number of articles, books, and chapters written on the topic. The content and breadth of coverage are farreaching. CSR is used as an umbrella term to account for the complex and multi-faceted relationships between business and society and the economic, social, and environmental impacts of business activities on the community. This literature review provides a synopsis of concepts and recent studies related to $\mathrm{CSR}, \mathrm{CP}$, and the chance of a relationship between the two.

\section{Corporate Social Responsibility (CSR)}

CSR has been a subject of study for some time, but no consensus concerning its definition and its constituent dimensions, constructs, and principles [7]. A study conducted a comprehensive review of CSR literature and identified 37 different definitions of CSR in 2008. The result from that study shows there is 
considerable variation in CSR perceptions and meanings [8].

For example, two authorities in the field of CSR offer two contrasting views of the responsibilities of business organizations to society. The first argues against the concept of CSR when stating that the only social responsibility of a company is to increase its profits while staying within the rules of the game [9].

In contrast, the second opinion argues that CSR requires consideration of paramount issues beyond the company's fundamental economic, technical, and legal requirements [10]. These two definitions sit on opposite sides. The first suggests that the responsibility of a business is only to its owners. In contrast, the second contends that the interests of other stakeholders, apart from the shareholders, should also be considered. To further put his idea into perspective, the second proposed that the managers of business organizations have four responsibilities that he outlined in order of priority: economic, legal, ethical, and discretionary. He acknowledges that a business must first make a profit to satisfy its financial responsibilities. To continue in existence, the organization must follow the laws and fulfill its legal obligations. There is evidence that companies that violate the law may experience lower profits and a decline in sales [11]. To this end, the two opinions agree.

The second, however, argues further that businesses have responsibilities beyond economic and legal ones. Ethical and discretionary trusts are social responsibilities that organizations should look to fulfilling. CSR, therefore, includes ethical and discretionary but not financial and legal, which are primary responsibilities for business organizations. The fascinating factor here is that both opinions argue their positions based on the impact of CSR actions on the organization's financial performance. The first says that CSR actions will negatively affect the economic efficiency of the business; on the other hand, the second proposes that lack of commitment to CSR results in increased government regulations which reduce the organization's effectiveness.

\section{Corporate Reputation}

According to past and recent research, it is quite clear that corporate reputation significantly contributes to the long-term competitive advantages of organizations, and that is its strategic success factor. Reputation is not easy to define because it depends on various stakeholders' views, intentions, and expectations of enterprise performance. Stakeholders, especially investors and suppliers, would see enterprise reputation from a different angle than the customers. Although both are directly involved, customers focus on quality and include business partners and suppliers mostly assess financial and overall business performance. In this sense, reputation could be defined from the aspect of creditworthiness when they are synonymous. From the customers' points of view, CSR "positively influences customer satisfaction and loyalty within consumer segments" [12, 13]. All other stakeholders - secondary group (media, syndicate, community, etc.) - will estimate from the overall perception mainly oriented to social and environmental interests. Corporate reputation is defined as "a global perception of the extent to which an organization is held in high esteem or regard" [14]. A professor of Business at Harvard Business School likened corporate reputation as a window to the fundamental character of a company and its leaders and, as such, is relevant to all stakeholders [15].

From the shareholders' points of view, reputation stands for a valuable asset, i.e., "intangible resource which may provide the organization with a basis for sustaining competitive advantage given its valuable and hard-to-imitate characteristics" $[15,16]$. Shareholders very often identify reputation with financial position and possibility to gain a profitable return. This is why the emphasis in 
literature is usually placed on enterprise reputation as a valuable resource and its association with financial performance [17-20]. A good reputation could increase sales or revenue and reduce operating costs; thus, reputation is viewed from the aspect of financial benefits and is directed through reputation financial performance relationship. Besides this relationship, it was found that financial performance affects reputation so we could talk about a "reputational vicious circle" [19]. In that case, motivation to accept social performance as one of the reputation determinants could be related to the outcomes of financial gains. Reputation, in a broader sense, could be defined as “a perceptual representation of a company's past actions and future prospects that describes the firm's overall appeal to all its key constituents when compared to other leading rivals" [21].

In co-operation with others, the same author has constructed a definition of reputation relating to various fields - economics, strategy, marketing, organisation theory, sociology, communication, and accounting. About this construction, the authors suggested that corporate reputation is a "collective construct that describes the aggregate perception of multiple stakeholders about a company's performance" [22]. This confirms the statement that reputation is hard to define precisely because it depends on stakeholders' perceptions. Except for this complexity, it should be taken into consideration that companies differ according to their size, business activity, structure, management and leadership, social performance, etc.

For example, heavy industry is more closely linked with some type of environmental and social issues than newer manufacturing industries or the services sector. For that reason, a study proposed that the distinction between types of business activities and social performance plays an important role in defining the relationship between social performance and corporate reputation [23].

\section{Reputation Dimensions}

As a valuable intangible asset, reputation should mostly be measured by qualitative measures. Nowadays, after so many financial scandals, accounting information and measurement are not very reliable and are insufficient for a holistic approach to corporate performance. More and more researchers and practitioners emphasize non-financial measurement instruments as more reliable means for the overall assessment of corporate performance and its reputation. Reputation, as valuable intangible assets, could not be judged only by financial performance, although some researchers argue that financial performance has a positive influence on reputation, i.e., it was found that financial performance affects reputation [19]. Reputation is a much broader concept and deserves to be estimated by qualitative and quantitative (financial and nonfinancial) indicators.

\section{Theoretical Framework}

\section{Theoretical Views of Corporate Social Responsibility (CSR)}

As earlier posited, CSR's staple idea holds that business and society are not separate but interlocked [24]. Scholars have identified theories to explain CSR. For instance, stakeholder theory explains how CSR is essential, and the contractual and legitimacy theories explain why CSR is critical [25]. CSR includes several theories, and many studies have discussed contractual/agency, stakeholder, and the social contract behind the idea of corporate social responsibility. However, this study is hinged on Legitimacy theory, as elaborated below.

\section{Legitimacy Theory}

Legitimacy theory is the most widely used theory to explain environmental and social disclosures [26]. According to a study, legitimacy theory is preferred chiefly over other theories because it provides disclosing strategies that organisations may utilize to legitimize their 
existence that may be empirically tested [27]. Legitimacy theory is traceable to the concept of organizational legitimacy, which has been described as a condition that exists when an organization's value system is consistent with the value system of the society of which the organization is a part [28]. There is a threat to the organization's legitimacy when a disparity, whether actual or potential, exists between the two value systems.

Legitimacy theory posits that entities repeatedly seek to ensure that they operate within the acceptable norms of their respective societies. In adopting a legitimacy theory perspective, an organization would willfully report on activities if managers perceived that those activities were relevant to the communities in which it operates [29-31]. Because community expectations vary over periods and time, the organization needs to make available information to show that it is also changing. The study indicates that legitimacy is a huge resource on which an organisation depends on survival [28].

Another study provides that, consistent with resource dependence theory, legitimacy theory suggests that whenever managers consider the supply of the resource as critical to organisational survival, they will pursue strategies to ensure the continued supply of that resource. Such strategies may include targeted disclosures or perhaps controlling or collaborating with other parties who, in themselves, are considered to be legitimate [29, 30]. Where managers perceive that the organisation's operations are not commensurate with the society's interest, then pursuant to legitimacy theory, organisations may take strategic action to become legitimate. Because the theory is based on perceptions, for remedial action to have an effect on external parties, it must be accompanied by publicised disclosure. Hence the importance of publicised corporate disclosures, such as those made within annual reports and other publicly released documents [31].

\section{Empirical Review}

They are considering the unethical company and brand perceptions, A study based on three empirical studies out to conceptualise and subsequently operationalise the construct of consumer perceived ethicality (CPE) of a company or brand. Study 1 investigates consumer meanings of the term ethical and reveals that, contrary to philosophical scholars' exclusively consequentialist or nonconsequentialist positions, consumers' ethical judgments are a function of both these evaluation principles, illustrating that not anyone's scholarly definition of ethics alone is capable of capturing the content domain. The resulting conceptualisation identifies six key themes explicating the construct. Studies 2 and 3 were built upon these findings to operationalise CPE. Such operationalisation is an essential prerequisite for future explorations and theory development, given the absence of a suitable tool to capture and quantify the strength and direction of CPE. The key focus was on developing a valid and reliable multi-item measurement tool that is practical, parsimonious, and easy to administer. The scale's general applicability allows deployment in academic and business contexts and different research areas and doing thus facilitates the much-needed theory building in this new research area $[32,33]$.

A study examined political, corporate social responsibility with the intent to review theories and set new agendas. The study anchored on a survey and content analysis of 146 related academic articles from selected journals over a 14-year period of 2000 to 2013. Legitimacy theory, the resource-based view, and Habermasian political theory were reviewed within the political CSR literature. The survey showed that the political CSR field is primarily dominated by institutional theory and stakeholder theory. However, future theory development needs to go beyond these theories to address several CSR critical gaps. This review specifically points to several avenues for future political CSR research with regard to the 
individual level of analysis, domain integration, and political CSR in multinational enterprises. The paper, therefore, calls for a new theoryinformed and pluralist research agenda on political CSR in order to integrate different perspectives and re-examine the role of the state [34].

Another study that assessed the relationship between corporate social responsibility and financial performance aims to review alternative operationalization and measurement approaches for the CSR and CFP concepts that have been deployed in empirical literature concerned with the CSR-CFP relationship. Several findings emanate from the study.

First, CSR operationalization in empirical literature ranges from multidimensional to onedimensional. Second, CSR measurement approaches include reputation indices, content analyses, questionnaire-based surveys, and onedimensional measures, whereas CFP measurement approaches include accountingbased measures, market-based measures, and combined measures. Third, no CSR measurement approach is without drawbacks [8]. In addition to approach specific drawbacks, two problems inherent in most approaches are researcher subjectivity and selection bias that may influence the nature of the CSR-CFP relationship detected in the empirical literature. The study recommends that standardisation and disclosure would be not only beneficial for valid testing of the CSR - CFP relationship but also for many stakeholders when making their economic decisions. A study carried out a latent variable analysis of corporate social responsibility and firm value using Data from United States firms between 2002 and 2014. The study adopted a firm-fixed effects model to control for time-invariant unobservable firmspecific characteristics that may drive both CSR and firm value. Environmental, social, and corporate governance activities were measures of CSR. The study finds conflicting evidence of a direct relationship between each CSR proxy and firm value. However, joint positive significance were recorded when all CSR proxies are incorporated into a latent variable model. The study recommended that firm values can be enhanced by corporate managers through simultaneous engaging in environmental, social, and corporate governance activities because of their synergistic effect with firm value [35].

\section{Methodology}

The methodology for this research was both quantitative and qualitative approach. It includes the specific techniques or procedures adopted for gathering information for the study. It involved the collection, collation, analyses, and interpretation of data for the study of interest. This study is designed with the conscious aim to serve business managers by examining the effect of corporate reputation on the performance of corporate organizations with operations in West Africa. The design is multiple regression analysis based.

\section{Research Design}

The study adopted a survey research design incorporating both a quantitative approach and a survey strategy for interviews. In the current research context, perceptions of the individuals were sought in order to examine the effect of corporate reputation on the performance of corporate organizations: Evidence from West Africa.

The use of surveys enabled the researcher to obtain valid and reliable information through analyzing and understanding the data from the corporations. This is because the design is useful and most appropriate in measuring the degree of association between two or more variables. It is also useful in measuring the effect of independent variables on a dependent variable [36]. The dimension of the independent variable was Reputation (REP). The measure of the dependent variable is Corporate Performance (COP). These will be measured in an interval scale through the research questionnaire. The statistical tool to analyze the set variables is multiple regression. 


\section{Population}

The population for our study consists of selected listed multinational companies in Nigeria. The chosen companies include Cadbury Nig., Nestle Nig Plc., Unilever Nig. Glaxo Smith Kline, 7up Bottling, Guinness Nig. Plc., PZ Cussons, Nigeria Breweries, Dangote
Cement, Dangote Sugar, Flour Mills Nig. These were selected based on their multinational capacity, and as a listed company in the Nigerian Stock Exchange, they are required to practice corporate social responsibility. From the companies' database, there were a total of 30492 employees.

Table 1. Total Population

\begin{tabular}{|l|l|}
\hline Companies Names & No. of Targeted Employees \\
\hline Cadbury Nigeria Plc. & 536 \\
\hline Nestle Nigeria Plc. & 2226 \\
\hline Unilever Nigeria Plc. & 1010 \\
\hline GlaxoSmithKline Nig. Plc. & 125 \\
\hline 7up Bottling Company Plc. & 3452 \\
\hline Guinness Nigeria Plc. & 822 \\
\hline PZ Cussons & 1392 \\
\hline Nigeria Breweries & 3195 \\
\hline Dangote Cement & 13360 \\
\hline Dangote Sugar & 694 \\
\hline Flour Mills Nig. & 3680 \\
\hline Total & 30492 \\
\hline
\end{tabular}

Source: Companies’ Database

\section{Sampling Techniques}

The study sample was based on the population comprising of multinational companies in Nigeria. The sampling technique is a simple sampling method. In this technique, all the items of the population have equal chances of being selected in a sample. The selection of items could be done through either simple sampling, systematic sampling, stratified sampling, or cluster sampling [37]. A stratified sampling technique was adopted to select the multinational companies. While a simple sampling technique was used to select respondents.

The simple sampling major advantage over simple random sampling is that it is faster and less susceptible to sampling errors. In stratified sampling, the target population is divided into homogeneous sub-populations before a simple or systematic sampling is then used to further select items equally [38].

\section{Sample Size Determination}

To ensure that the sample size is truly reflective of the population, the Taro Yemen formula was used in this study. Since the larger the size of the population, the more precise the results, the investigation sample was drawn based on a 95the \% level of confidence. The Taro Yamene formula is given as:

$$
\mathrm{n}=\frac{\mathrm{N}}{1+N(e)^{2}}
$$

Where:

$$
\begin{aligned}
\mathrm{n}= & \text { Sample size } \\
\mathrm{N}= & \text { Population size } \\
\mathrm{e}= & \text { Margin of error }(5 \%) \\
& n=\frac{30492}{1+30492(0.05)^{2}} \\
= & \frac{30492}{1+30492(0.0025)} \\
& =\frac{30492}{1+76.23}
\end{aligned}
$$




$$
\begin{aligned}
& =\frac{30492}{77.23} \\
& =394.82
\end{aligned}
$$

$\mathrm{n}=395$, therefore the number of questionnaires administered is 395 .

\section{$=395$ approximately}

Table 2: Sample Number from Companies

\begin{tabular}{|l|l|l|l|}
\hline Companies Names (A) & $\begin{array}{l}\text { No. of Targeted } \\
\text { Employees }(B)\end{array}$ & $\begin{array}{l}\text { Percentage of } \\
\text { Total }(\mathbf{C})\end{array}$ & $\begin{array}{l}\text { Number from } \\
\text { Sample }\left(\mathbf{C}^{* 395)}\right.\end{array}$ \\
\hline Cadbury Nigeria Plc. & 536 & 0.018 & 7 \\
\hline Nestle Nigeria Plc. & 2226 & 0.073 & 29 \\
\hline Unilever Nigeria Plc. & 1010 & 0.033 & 13 \\
\hline GlaxoSmithKline Nig. Plc. & 125 & 0.004 & 2 \\
\hline 7up Bottling Company Plc. & 3452 & 0.113 & 45 \\
\hline Guinness Nigeria Plc. & 822 & 0.027 & 11 \\
\hline PZ Cussons & 1392 & 0.045 & 18 \\
\hline Nigeria Breweries & 3195 & 0.105 & 41 \\
\hline Dangote Cement & 13360 & 0.438 & 173 \\
\hline Dangote Sugar & 694 & 0.023 & 9 \\
\hline Flour Mills Nig. & 3680 & 0.121 & 47 \\
\hline Total & 30492 & 1.000 & 395 \\
\hline
\end{tabular}

Source: Authors' Computation

\section{Data Collection}

\section{Questionnaire}

Questionnaires were used to obtain the primary data required for this work, and these were administered by 10 persons trained by the researcher for the purpose of data collection in the field. Questionnaires are best suited for surveys [37]. Its selection was guided by the nature of data to be collected, the time available, and the study objectives.

Questionnaires have the advantage of upholding confidentiality, saving on time, reducing interviewer 's bias, wider coverage, and are easier to analyze [36]. The research adopted 5 Likert scale of Strongly Agreed (SA) $=5$, Agreed $(\mathrm{A})=4$, Undecided $(\mathrm{U})=3$, Disagreed $(\mathrm{D})=2$ and Strongly Disagreed (SD) $=1$ in rating the responses from the respondents. The respondents were required to read, understand, and tick an appropriate choice. The questionnaires were administered by the trained persons so as to obtain more information and also obtain clarity of information obtained from the respondents.

\section{Model Specification}

Our model for the study is anchored on previous studies with modifications. As mentioned in the previous section and in line with recent literature [34, 39]. Multiple regression using ANOVA was used as the research method for analyzing corporate reputation and its impact on the performance of corporate organizations. Therefore, the following equation is formulated for the study.

$$
C O P=f(R E P) \text {. }
$$

Expressing the functional notation in equation (1.0) in econometric form.

$$
\begin{aligned}
C O P=\beta_{0}+\beta_{1} & +R E P \\
& +\varepsilon_{1} \cdots
\end{aligned}
$$

Where:

COP $=$ Corporate Performance
REP $=$ Reputation
$\beta_{0}=$ Constant


$\beta_{1} \quad=$ Coefficients

$\varepsilon_{\mathrm{i}} \quad=\quad$ Error term

\section{Result and Discussion}

Response Rate: This chapter deals with the presentation, analysis and interpretation of the data obtained. The presentation of data was organized in accordance with the research questions and the hypotheses formulated for the study. Discussions of the findings were also made.

\section{Return Rate of Questionnaire}

Table 3. Return Rate of Questionnaire

\begin{tabular}{|l|l|l|l|l|l|}
\hline $\begin{array}{l}\text { Companies } \\
\text { Samples }\end{array}$ & Administered & $\begin{array}{l}\text { Correctly } \\
\text { Filled and } \\
\text { Returned }\end{array}$ & $\begin{array}{l}\text { Correctly } \\
\text { Filled and } \\
\text { Returned (\%) }\end{array}$ & $\begin{array}{l}\text { Incorrectly } \\
\text { Filled or Not } \\
\text { Returned }\end{array}$ & $\begin{array}{l}\text { Incorrectly } \\
\text { Filled or Not } \\
\text { Returned (\%) }\end{array}$ \\
\hline Cadbury Nig. & 7 & 7 & 1.8 & 0 & 0 \\
\hline Nestle Nig. & 29 & 28 & 7.1 & 1 & 0.25 \\
\hline Unilever Nig. & 13 & 12 & 3.0 & 1 & 0.25 \\
\hline GSK. Nig. & 2 & 2 & 0.5 & 0 & 0 \\
\hline 7up Bottling & 45 & 43 & 10.9 & 2 & 0.5 \\
\hline Guinness Nig. & 11 & 11 & 2.8 & 0 & 0 \\
\hline PZ Cussons & 18 & 17 & 4.3 & 1 & 0.25 \\
\hline Nig. Breweries & 41 & 40 & 10.1 & 1 & 0.25 \\
\hline Dangote Cement & 173 & 170 & 43.0 & 3 & 0.8 \\
\hline Dangote Sugar & 9 & 9 & 2.3 & 0 & 0 \\
\hline Flour Mills Nig. & 47 & 45 & 11.4 & 2 & 0.5 \\
\hline Total & $\mathbf{3 9 5}$ & $\mathbf{3 8 4}$ & $\mathbf{9 7 . 2}$ & $\mathbf{1 1}$ & $\mathbf{2 . 8}$ \\
\hline
\end{tabular}

Source: Field Survey, 2020

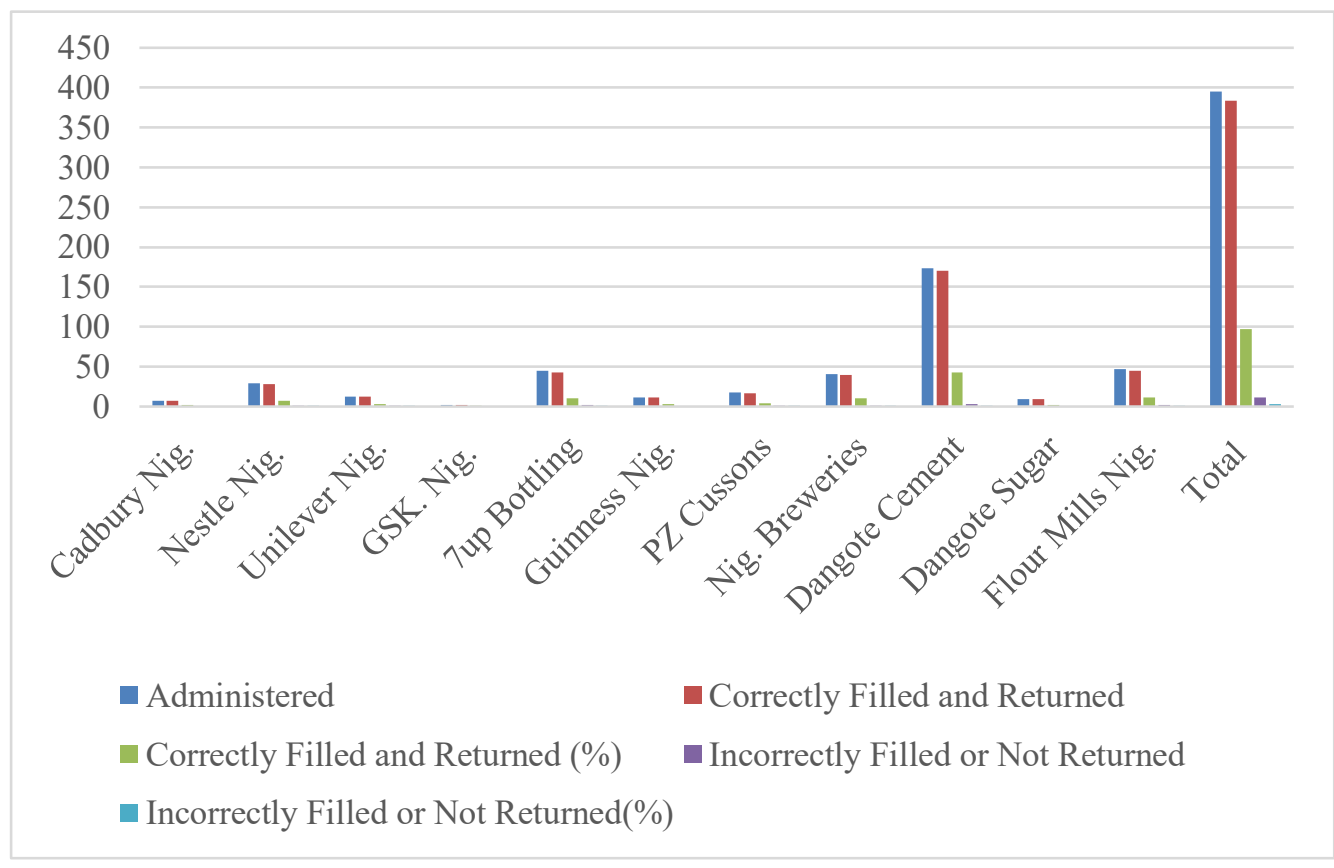

Figure 1. Analysis of Questionnaires Distributed to Companies Selected for this Study

Source: Field Survey, 2020 
The above table and chart sho that three hundred and ninety-five (395) copies of the questionnaire were administered to the respondents from each selected companies. Out of this number, three hundred and eighty-four (384) were correctly filled and returned, while eleven (11) copies were not correctly filled or not returned (see Table 3). This gives a response rate of $97.2 \%$. From these responses, data was organized, interested, and presented in this chapter.

\section{Background Information}

\section{Demographic Information}

Demographic results in table 4 revealed that $54.7 \%$ (210) were male and $45.3 \%$ (174) were female. It also revealed that most, $74.0 \%$ (284), were married, followed by $17.2 \%$ (66) which were single, and only $8.9 \%$ (34) respondents were divorced. The result also revealed that most $33.9 \%$ (130) of the respondents were aged between 36 - 45 years, followed closely by $29.9 \%$ (115) aged 46 years and above. $21.6 \%$
(83) were aged 26 - 35 years, and only $14.6 \%$ (56) were aged $16-25$ years.

In terms of their education qualification, $22.4 \%$ (86) of the respondents had their Senior Secondary Certificate Examination (SSCE), $8.6 \%$ (33), and 8.3\% (32) of the respondents had Ordinary National Diploma (OND) and Higher National Diploma (HND) respectively. 19\% (73) of the respondent had Master Certificate, 36.2\% (139) of the respondent had Master Certificate, and $5.5 \%$ (21) respondents had another certificate. Regarding their years in the corporation, $67.7 \%$ (260) of the respondents had stayed a decade and above, while $32.3 \%$ (124) were less than a decade in the corporation. Furthermore, $47.1 \%$ (181) of the respondents were low-level managers, 36.2\% (139 (were) middle-level manager, and $16.7 \%$ (64) were toplevel manager. This shows that men and women are almost equally involved in decision-making in the selected companies. It further revealed that the corporation had people of various ages and academic qualifications among the workforce with different years of experience.

Table 4. Demographic Information

\begin{tabular}{|l|l|l|}
\hline Variables & Frequency & Percentage \\
\hline Sex & 210 & 54.7 \\
\hline Male & 174 & 45.3 \\
\hline Female & $\mathbf{3 8 4}$ & $\mathbf{1 0 0}$ \\
\hline Total & 66 & 17.2 \\
\hline Marital Status & 284 & 74.0 \\
\hline Single & 34 & 8.9 \\
\hline Married & $\mathbf{3 8 4}$ & $\mathbf{1 0 0}$ \\
\hline Divorced & 56 & 14.6 \\
\hline Total & 83 & 21.6 \\
\hline Age & 130 & 33.9 \\
\hline $16-25$ Years & 115 & 29.9 \\
\hline 26-35 Years & $\mathbf{3 8 4}$ & $\mathbf{1 0 0}$ \\
\hline 36-45 Years & 124 & 32.3 \\
\hline 46 Years and above & 67.7 \\
\hline Total & 260 & \\
\hline Years in Corporation & \\
\hline Less than a decade & 15 \\
\hline A decade and above &
\end{tabular}




\begin{tabular}{|l|l|l|}
\hline Total & $\mathbf{3 8 4}$ & $\mathbf{1 0 0}$ \\
\hline Job Level & 181 & 47.1 \\
\hline Low level manager & 139 & 36.2 \\
\hline Middle Level manager & 139 & 16.7 \\
\hline Top Level manager & 64 & $\mathbf{1 0 0}$ \\
\hline \multicolumn{2}{|l|}{ Total } & $\mathbf{3 8 4}$ \\
\hline \multicolumn{2}{|l|}{ Education Qualification } \\
\hline SSCE & 86 & 22.4 \\
\hline OND & 33 & 8.6 \\
\hline HND & 32 & 8.3 \\
\hline BSC/BA & 139 & 36.2 \\
\hline MSC/MBA & 73 & 19.0 \\
\hline Others & 21 & 5.5 \\
\hline Total & $\mathbf{3 8 4}$ & $\mathbf{1 0 0}$ \\
\hline
\end{tabular}

Source: Field Survey, 2020

\section{Specific Research Findings}

This section provides descriptive statistics, including frequencies, percentages, the mean and standard deviation for reputation and Corporate Performance. Therefore, descriptive statistics enable us to present the data in a more meaningful way, which allows a more straightforward interpretation of the data.

\section{Reputation (REP)}

Further, the reputation of the corporation was inquired from the respondents. From the study results, maintaining high-quality products has boosted the reputation of the corporation (mean $=4.4$ ), and the corporation considers various stakeholders when implementing social responsibility policies $($ mean $=3.51)$. The corporation has competent personnel dedicated to responding to complaints and brand-related issues (mean $=3.5)$. However, the respondents expressed concern whether engaging the community through various socio-economic initiatives has been effective (mean $=2.78$ ). Also, there was doubt whether the internet and social media platforms have been adopted to promote the corporations' reputation (mean $=$ 2.33) - responses on reputation show skewness of 0.79 and kurtosis of -0.50 . A similar study reports that corporate reputation is a critical resource and contributes mainly to the organization's performance or success. It can contribute to an organization's failure $[40, \&$ 41].

Table 5. Descriptive Statistics for Reputation (Frequencies, Percentages, means, and Standard Deviation)

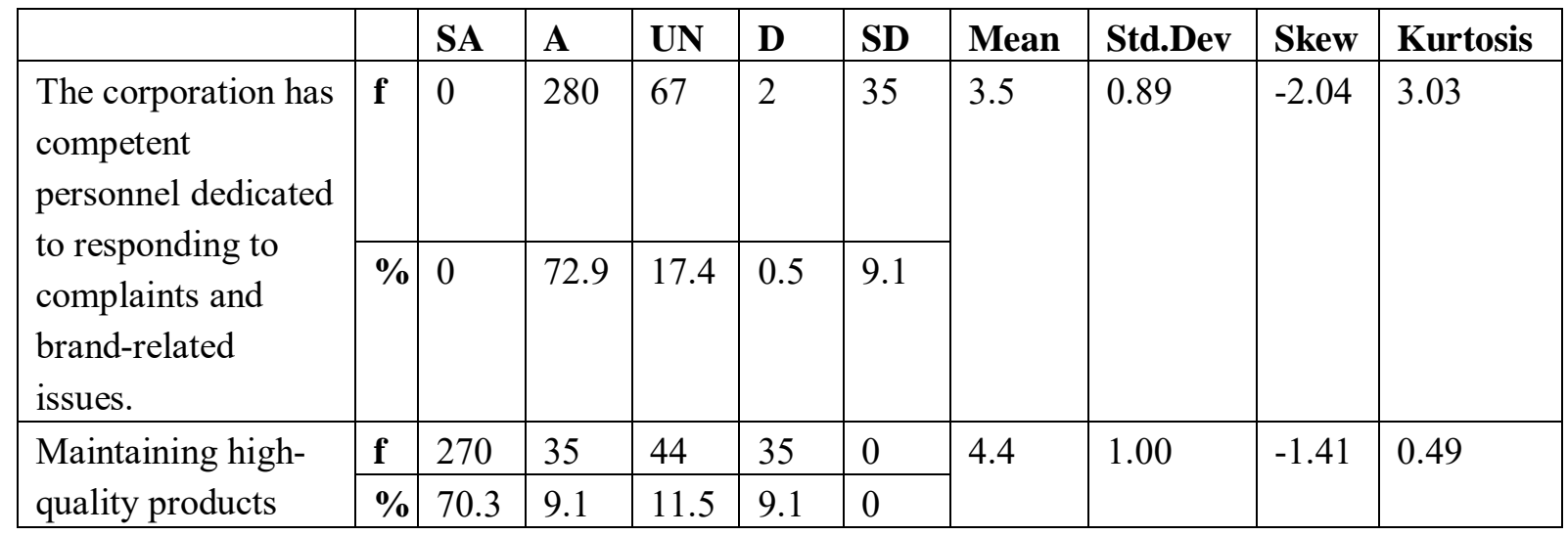




\begin{tabular}{|c|c|c|c|c|c|c|c|c|c|c|}
\hline $\begin{array}{l}\text { has boosted the } \\
\text { reputation of the } \\
\text { corporation. }\end{array}$ & & & & & & & & & & \\
\hline \multirow[b]{2}{*}{$\begin{array}{l}\text { The internet and } \\
\text { social media } \\
\text { platforms have } \\
\text { been adopted to } \\
\text { promote the } \\
\text { corporations' } \\
\text { reputation. }\end{array}$} & f & 33 & 36 & 1 & 271 & 43 & \multirow[t]{2}{*}{2.33} & \multirow[t]{2}{*}{1.07} & \multirow[t]{2}{*}{1.43} & \multirow[t]{2}{*}{1.12} \\
\hline & $\%$ & 8.6 & 9.4 & 0.3 & 70.6 & 11.2 & & & & \\
\hline \multirow[b]{2}{*}{$\begin{array}{l}\text { Engaging the } \\
\text { community through } \\
\text { various socio- } \\
\text { economic } \\
\text { initiatives has been } \\
\text { effective. }\end{array}$} & f & 68 & 33 & 67 & 182 & 34 & \multirow[t]{2}{*}{2.78} & \multirow[t]{2}{*}{1.25} & \multirow[t]{2}{*}{0.67} & \multirow[t]{2}{*}{-0.78} \\
\hline & $\%$ & 17.7 & 6.6 & 17.4 & 47.4 & 8.9 & & & & \\
\hline \multirow[b]{2}{*}{$\begin{array}{l}\text { The corporation } \\
\text { considers various } \\
\text { stakeholders when } \\
\text { implementing } \\
\text { social responsibility } \\
\text { policies. }\end{array}$} & f & 138 & 104 & 33 & 34 & 75 & \multirow[t]{2}{*}{3.51} & \multirow[t]{2}{*}{1.52} & \multirow[t]{2}{*}{-0.62} & \multirow[t]{2}{*}{-1.13} \\
\hline & $\%$ & 35.9 & 27.1 & 8.6 & 8.9 & 19.5 & & & & \\
\hline \multicolumn{7}{|l|}{ Reputation } & 3.25 & 0.45 & 0.79 & -0.503 \\
\hline
\end{tabular}

Source: Field Survey, 2020

\section{Multiple Regression Result}

The regression result from table 6 shows that the study multiple regression model had a coefficient of determination $\left(\mathrm{R}^{2}\right)$ of 0.527 . This means that community development \& philanthropy, reputation, internationalization, environmental sensitivity, employee diversity, and leadership ethics explain a $52.7 \%$ variation of corporate performance. Furthermore, the reveals that the F-value of 70.029 with a p-value of 0.00 significant at $5 \%$ indicates that the overall regression model is significant; hence, the joint contribution of the independent variables was significant in predicting the corporate performance.

Table 6. Multiple Regression Results

\begin{tabular}{|l|l|l|l|l|l|}
\hline \multirow{2}{*}{ Model } & Unstandardized Coefficients & Standardized Coefficients & t & Sig. \\
\cline { 2 - 6 } & B & Std. Error & Beta & & \\
\hline (Constant) & -2.641 & .494 & & -5.350 & .000 \\
\hline Reputation & .227 & .108 & .089 & 2.105 & .036 \\
\hline R Square 0.527 & & & \\
\hline Adjusted R Square 0.520 & & \\
\hline F 70.029 \\
\hline Sig. 0.000 \\
\hline
\end{tabular}

Source: SPSS 20.0 


\section{Test of Hypothesis}

To test for hypotheses, we first state the null and alternative forms to create a clear understanding of the tentative statements.

\section{Decision Rule}

The decision rule is to reject the null hypothesis and accept the alternative if the sig. Value of the variables under study is lower than 0.05 level of significance.

$\mathrm{Ho}_{1}$ : Firm's reputation does not significantly affect the performance of corporate organizations in developing countries.

$\mathrm{H}_{\mathrm{A} 1}$ : Firm's reputation significantly affects the performance of corporate organizations in developing countries.

Table 7. Standardized Coefficient

\begin{tabular}{|l|l|l|l|}
\hline Variable & Standardized Coefficient (Beta) & t-Stat & Sig. \\
\hline Reputation & 0.089 & 2.105 & 0.036 \\
\hline
\end{tabular}

Source: Extracted from Table

The second hypothesis $\left(\mathrm{Ho}_{1}\right)$ of the study stipulates that firm's reputation do not significantly affect the performance of corporate organizations in developing countries. Study result findings from table 7 rejected the hypothesis as evidenced by $\beta_{2}=0.089, \rho<0.05$, implying that firm's reputation significantly affects the performance of corporate organizations in developing countries. We, therefore, reject the null hypothesis that a firm's reputation do not significantly affect the performance of corporate organizations in developing countries.

This shows that the higher a firm's reputation, the higher the performance. These findings are consistent with another study which posits that corporate reputation as a logical outcome of the quality of corporate governance operated in an organization [40].

\section{Summary of Findings}

The study investigated the effect of corporate reputation on the performance of corporate organizations in developing countries using evidence from West Africa. The relevance of corporate reputation in enhancing the performance of corporate organizations have ignited concerns of scholars following the world globalization with related challenges. The study adopted various tests to establish the association between the variables under study. The effect of
Reputation (REP) on the performance of corporate organizations was tested and the study established from the regression that there is a positive effect of Reputation (REP) on performance of corporate organizations. This is evidenced by the coefficient value of 0.089 . Statistically, the Sig. Value of 0.036 is lower than the acceptable significance value of 0.05 . Following the empirical result, Reputation (REP) is found to have a positive and significant effect on the performance of corporate organizations.

The powerful effect is in line with a study showing that funds meant to be invested in the CSR in the various companies are not sufficient. Furthermore, another study posits that the key to good results lies in establishing a strong informative system that, to the extent possible, links specific CSR expenditure decisions so as to ensure the usage of the allocated fund as transparently as possible [43]. However, another study noted that the efficiency of corporations' expenditure for building intangible assets like reputation and brand varies across nations [44]. The finding reveals that as in reputation, financing has increased over the years with its growing relevance adequately.

\section{Conclusion}

In conclusion, the heterogeneity that exists among corporate reputation variable as it relates 
to the performance of corporate organizations call for re-engineering in order to explore the potential growth virtues embedded in corporate reputation that are yet to be adopted by organizations. The positive coefficients of reputation, in relation to the performance of corporate organizations in developing countries, is a further indicator that the organizations can become better through the long-term focus strategy on these practices to accelerate performance. The study also reveals that the many environmental challenges faced by multinationals emanating from corporate social responsibilities can be well addressed through enhanced strategic policy implementation.

\section{Recommendation}

Reputation (REP) from our study has a positive coefficient is a significant effect. This means that reputation building by corporations contributes to the performance of the corporations meaningfully. We advocate for an increase in the level of attention given to the reputation of the corporation in carrying out their numerous activities.

\section{Conflict of Interest}

I hereby certify that, to the best of my knowledge: No financial support or benefits have been received by me, by any member of my immediate family, or any individual or entity

\section{References}

[1] Rieschick, G. (2017). Corporate social responsibility and corporate financial performance in food, and beverage industry (Doctoral dissertation). Retrieved from Walden Dissertations and Doctoral Studies.

https://scholarworks.waldenu.edu/dissertations/4677

[2] Akhalumeh, P., Odion, O., \&Ohiokha, F., (2016). Corporate Social Responsibility and Corporate Financial Performance: The Nigerian Experience. with whom or with which I have a significant relationship from any commercial source which is related directly or indirectly to the work which is reported on in the article. I declare that I have no conflict of interest.

\section{Acknowledgement}

I owe an enormous debt to different people for helping me create this doctoral thesis.

First, my deepest gratitude goes to my Guide/Supervisor, Professor James C. Ihemeje, Professor of Finance at the Michael Okpara University of Agriculture Umudike, for his guidance, scholarly support, and dedication of time, without which this thesis would not have become a reality.

Secondly, I acknowledge my CoGuide/Supervisor, Dr.N.S. Shanthi, for her scholarly support and commitment of time throughout this process. I am also thankful to Dr. Janani S.B., my Research Coordinator, Dr. Kulothungan, my student mentor, and Dr. Ogochukwu E.S. Nebo, my alumni mentor, for inspiring me to complete this doctoral thesis and for providing me with unlimited academic support.

The fine team of professionals at the School of Research, Texila American University, has also been instrumental to the success of my program and for this thesis. I will admire their dedication throughout my life.

International Journal of Accounting Research, 2, 113. doi: $10.12816 / 0027131$

[3] Yu-Shu, P., Chyi-Lin, H., \&Altan-Uya, D., (2015). Corporate Social Responsibility and Corporate Financial Performance: The Intervening Effect of Social Capital. Journal of Advanced Management Science, 3(4), 276-283. Doi: 10.12720/joams.3.4.276-283.

[4] Tilakasiri, K.K. (2012). Corporate social responsibility and company performance: Evidence from Sri Lanka (Doctoral dissertation). Retrieved from VU Research Repository. 
http://vuir.vu.edu.au/21488/1/Korathotage_Kamal_T ilakasiri.pdf.

[5] Babalola, A. (2012). The Impact of Corporate Social Responsibility on Firm's Profitability in Nigeria. European Journal of Economics, Finance and Administrative Sciences, 45, 39-50. Retrieved from

https://www.kau.edu.sa/Files/0060841/Subjects/imp act $\% 20$ on\%20profitiability.pdf.

[6] Jamali D., \&Sidani Y. (2012). Introduction: CSR in the Middle East: Fresh Perspectives. In: Jamali D., Sidani Y. (eds) CSR in the Middle East. (pp. 1-10). doi.org/10.1057/9781137266200_1.

[7] Nguyen, H.T., Le, D.M.D., Ho, T.T.M., \& Nguyen, P.M., (2020). Enhancing Sustainability in the Contemporary Model of CSR: A Case of Fast Fashion Industry in Developing Countries. Social Responsibility Journal, 17(4), 578-591. https://doi.org/10.1108/SRJ-03-2019-0108.

[8] Galant, A., \& Cadez, S. (2017). Corporate Social Responsibility and Financial Performance Relationship: A Review of Measurement Approaches. Economic ResearchEkonomskaIstraživanja, 30(1), 676-693. doi: 10.1080/1331677X.2017.1313122.

[9] Friedman, M. (1970). Capitalism and Freedom: Fortieth Anniversary Edition.

[10]Carroll, A., (1979). A Three-Dimensional Conceptual Model of Corporate Performance. Academy of Management Review, 4(4): 479-505.

[11]Baucus, M., \& Baucus, D. (1997). Paying the Piper: An Empirical Examination of Longer-Term Financial Consequences of Illegal Corporate Behavior. The Academy of Management Journal, 40, 129-151. doi: 10.2307/257023.

[12]Helm, S. (2007). One reputation or many? Comparing stakeholders' perception of corporate reputation, Corporate Communications: An International Journal, 12(3), 238-254.

[13] Sarstedt, M., Ringle, C. M., Schloderer, M. P., and Schwaiger, M., (2008). Accounting for Unobserved Heterogeneity in the Analysis of Antecedents and Consequences of Corporate Reputation: An Application of FIMIX-PLS, Proceedings of the $37^{\text {th }}$ Annual Conference of the
European Marketing Academy, Brighton, England, 27-30 May 2008, EMAC.

[14] Weiss, A. M., Anderson, E. and MacInnis, D. J. (1999). Reputation Management as A Motivation for Sales Structure Decisions, Journal of Marketing, 63(4).74-89.

[15]Hall, R., (1993). A Framework Linking Intangible Resources and Capabilities to Sustainable Competitive Advantage. Strategic Management Journal, 14, 607-618.

[16]Barney, J., (1991). Firm Resources and Sustainable Competitive Advantage. Journal of Management, 17, 99-120.

[17]Roberts, P.W., and Dowling, G.R., (2002). Corporate Reputation and Sustained Superior Financial Performance. Strategic Management Journal, 23, 1077-1093. https://doi.org/10.1002/smj.274.

[18]Eberl, M., Schwaiger, M, (2005). Corporate Reputation: Disentangling the Effects on Financial Performance, European Journal of Marketing, 39(7/8), 834-54.

[19]Rose, C., \& Thomsen, S., (2004). The Impact of Corporate Reputation on Performance: Some Danish Evidence. European Management Journal, 22(2), 201-210.

[20] Inglis, R. Morley, C., Sammut, P., (2006). Corporate Reputation and Organisational Performance: An Australian Study. Managerial Auditing Journal, 21(9) 934-947.

[21]Fombrun, C., 1996, Reputation: Realizing Value from the Corporate Image, (Harvard Business School Press, Boston, MA).

[22] Fombrun, C., Gardberg, N., \& Sever, J., (2000). The reputation quotient SM: A Multi-stakeholders Measure of Corporate Reputation. The Journal of Brand Management, 7, 241-255.

[23] Brammer, S., \& Pavelin, S., (2004). Building a Good Reputation. European Management Journal, 22, 704-713. 10.1016/j.emj.2004.09.033.

[24] Wood D., (1991). Corporate Social Performance Revisited. The Academy of Management Review, 16(4), 691-717. 
[25]Moir L., (2001). What Do We Mean by Corporate Social Responsibility? Corporate Governance, 1(2), 16-22.

[26] Campbell D., Craven B., \& Shrives P., (2003). Voluntary Social Reporting in Three FTSE Sectors: A Comment on Perception and Legitimacy. Accounting, Auditing and Accountability Journal, 16(4), 558-581.

[27] Gray, R., Kouhy, R. \& Lavers, S., (1995). Corporate Social and Environmental Reporting: A Review of the Literature and a Longitudinal Study of UK Disclosure. Accounting, Auditing \& Accountability Journal, 8(2), 47-77. https://doi.org/10.1108/09513579510146996.

[28] Dowling, J., \& Pfeffer, J., (1975). Organizational Legitimacy: Social Values and Organizational Behavior. Pacific Sociological Review, 18(1), 122 136. https://doi.org/10.2307/1388226.

[29]Deegan, C., (2002). Introduction: The Legitimising Effect of Social and Environmental Disclosures - A Theoretical Foundation. Accounting, Auditing \& Accountability Journal, 15(3), 282-311. https://doi.org/10.1108/09513570210435852.

[30]Deegan, C., Rankin, M., \& Voght, P., (2000). Firms' Disclosure Reactions to Major Social Incidents: Australian Evidence. Accounting Forum, 24(1), 101-130.

[31]Cormier, D., \& Gordon, I.M., (2001). An Examination of Social and Environmental Reporting Strategies. Accounting, Auditing \& Accountability Journal, $\quad$ 14(5), 587-617. https://doi.org/10.1108/EUM0000000006264.

[32]Pfeffer, J., \& Salancik, G., 1978, The external control of organizations: A resource dependence perspective. (Harper \& Row, New York).

[33]Brunk, K., (2012). Unethical company and Brand Perceptions: Conceptualizing and Operationalizing Consumer Meanings. Journal of Business $\quad$ Ethics, 111(4), 551-565. doi:10.1007/s10551-012-1339-x.

[34]Frynas, J. G., \& Stephens, S., (2015). Political Corporate Social Responsibility: Reviewing Theories and Setting New Agendas. International Journal of Management Reviews, 17(4), 483-509.
[35] Jitmaneeroj, B., (2018). A Latent Variable Analysis of Corporate Social Responsibility and Firm Value. Managerial Finance, Vol. 44(4), 478-494. https://doi.org/10.1108/MF-08-2017-0303.

[36] Tang, Q., \& Zhang, C., (2013). Data Processing System (DPS) Software with Experimental Design, Statistical Analysis, and Data Mining Developed for Use in Entomological Research. Insect Science, 20, 254-260. doi:10.1111/j.1744-7917.2012. 01519.x.

[37] Yusoff, H., Abdul Jamal, A.D., \& Darus, F., (2016). Corporate Governance and Corporate Social Responsibility Disclosures: An Emphasis on the CSR Key Dimensions. Journal of Accounting and Auditing: Research \& Practice, 1-14.

[38]Aykol, B., \& Leonidou, L. C., (2014). Researching the Green Practices of Smaller Service Firms: A Theoretical, Methodological, and Empirical Assessment. Journal of Small Business Management, 53, 192-209. doi:10.1111/jsbm.12118.

[39] Mellahi, K., Frynas, J. G., Sun, P., \& Siegel, D., (2015). A Review of the Nonmarket Strategy Literature toward a Multi-Theoretical Integration. Journal of Management, 42(1), 143 -173.

[40] Aniuga, C. \& Okolo, A. N. (2015) The Impact of Corporate Reputation on Company's Performance. Communication Panorama African and Global Perspectives 1(1), 1 - 15.

[41] Honggui, G. L., Zhongwei, W. C., \&Guoxin, X. M., (2016). Corporate Reputation and Performance: A Legitimacy Perspective. Entrepreneurial Business and Economic Review, 4(3), 181 - 193. DOI: 10.15678/EBER.2016.040313.

[42] Kiessling, T., Isaksson, L., \& Yasar, B., (2015). Market Orientation and CSR: Performance Implications. Journal of Business Ethics, 137. doi: 10.1007/s10551-015-2555-y.

[43] Saadaoui, K., \&Soobaroyen, T., (2018). An Analysis of the Methodologies Adopted by CSR Rating Agencies. Sustainability Accounting, Management and Policy Journal, 9(1), 43-62. https://doi.org/10.1108/SAMPJ-06-2016-0031.

[44]Nelson, G., \& Evans, S. D., (2014). Critical Community Psychology and Qualitative Research: A Conversation. Qualitative Inquiry, 20, 158-166. doi:10.1177/1077800413510873. 


\title{
Application of the Deming PDSA Cycle as a Patient Experience Management Tool to Improve HIV Care. An Action Research in Under- Resourced Settings of Jinja-Uganda
}

\author{
Balidawa John \\ Lecturer, UNICAF University, Uganda
}

\begin{abstract}
The study to determine the effect of patient experience management using the Deming PDSA cycle on the quality of HIV care was conducted in under-resourced settings of Uganda. The interventional study had 437 files studied, and 224 adult HIV clients with poor HIV care outcomes of; missed appointments for more than two weeks, poor adherence to treatment of $<85 \%$, and unsuppressed viral load of > 1000 viral copies per milliliter were interviewed at baseline and end line. The study revealed a $13.6 \%$ prevalence of the study HIV care outcomes among all the client files, the majority of which were for patients in care for more than four years. $11.8 \%, 65.2 \%$, and $46.5 \%$ were due to poor adherence to treatment, two weeks missed appointments, and unsuppressed viral load at baseline, which reduced to $4.7 \%, 25.1 \%$, and $31.5 \%$ at end-line assessment, respectively. $80 \%$ of the studied clients were retention in care between the baseline and end-line assessments. $7.7 \%$ of the study files had never had a viral load done to the clients at baseline, which reduced to $1.4 \%$ at the end line. $34.5 \%$ of the study client files were overdue for a viral load at baseline but only $16.8 \%$ at end-line assessment. The study also showed a general improvement on the patient experience before and after interventions. In conclusion, Patient Experience Management using the Deming PDSA cycles improves the quality of HIV care in under-resourced settings.
\end{abstract}

Keywords: Deming PDSA cycles, Management, Patient Experience.

\section{Introduction}

Quality healthcare is achieved through continuous quality improvement, which concept was started in 1982 by Deming, who demonstrated the science of improvement using the Plan-Do-Study-Act (PDSA) cycle [1]. Patient-centred care, one of the dimensions of quality healthcare, is well documented in the Uganda National health sector quality improvement framework and strategic plan $2015 / 16-2019 / 20$ as one of the approaches to improve the quality of care in the Ugandan healthcare system. The study of "Application of the Deming PDSA cycle as a patient experience management tool to improve HIV care, was an action research in under resourced settings of Jinja- Uganda" to provides an alternative to the current quality improvement approaches. Patient experience is a patient-centred care, a concept that started in the 1980s, create a positive patient experience, and it is until today relevant in the healthcare environment [2].

In recent years, perceptions of performance and quality of healthcare organizations have begun to move beyond examining the provision of excellent clinical care alone, but to consider and embrace the patient experience as an important indicator [3]. Patient experience is defined as "the sum of all interactions, shaped by an organization's culture, that influence patient perceptions, across the continuum of care" [2] [3]. It is an important factor in patient perception of quality, leading to better utilization and adherence to treatment [4]. It is known that poor 
adherence to treatment in HIV care leads to unsuppressed viral load, high chances of HIV transmission, and drug resistance hence the use of second and third-line regimens that are expensive.

\section{Background}

The quality of HIV care and management in Uganda is unsatisfactory, with $59.6 \%$ prevalence of viral suppression nationally and $48.8 \%$ for the East central region where Jinja is located. Jinja district, with 28486 active HIV patients in care, has 2848 patients on second-line regimen of ARVs. The district also has 7.9\% (2250) miss appointments, 5.3\% (1509) poor adherence to treatment, and $10.4 \%$ (2962) of HIV clients with unsuppressed viral load. The poor HIV care outcomes are attributed to poor patient adherence to treatment. The situation was worsened by the adoption of the Test and Treat Guidelines of WHO in 2016 by Uganda, which increased the number of HIV clients into care from 21571 to 28486, amidst limited resources, ARV stock-outs, and lack of service providers skilled in adherence counseling.
To determine the prevalence of poor HIV care outcomes among patients in care, to determine the patient experience of clients with poor HIV care outcomes, and to determine the effect of application of Deming PDSA cycle as a patient experience management tool on the quality of HIV care.

\section{Justification}

The study was intended to provide new ideas on using patient experience management as an approach to improve the quality of HIV care in under-resourced settings. The study was to support the decision-makers and other stakeholders to make decisions, policies, and guidance based on evidence. The study was also to improve on patient-centred care for improved patient adherence to care and treatment reduced missed appointments and improved viral suppression and health status of HIV patients. It was anticipated that the public health outcome of the study will contribute to reduced HIV transmission with improved viral suppression. The policy makers are to make policies with evidence from the study.

\section{Study Objectives}

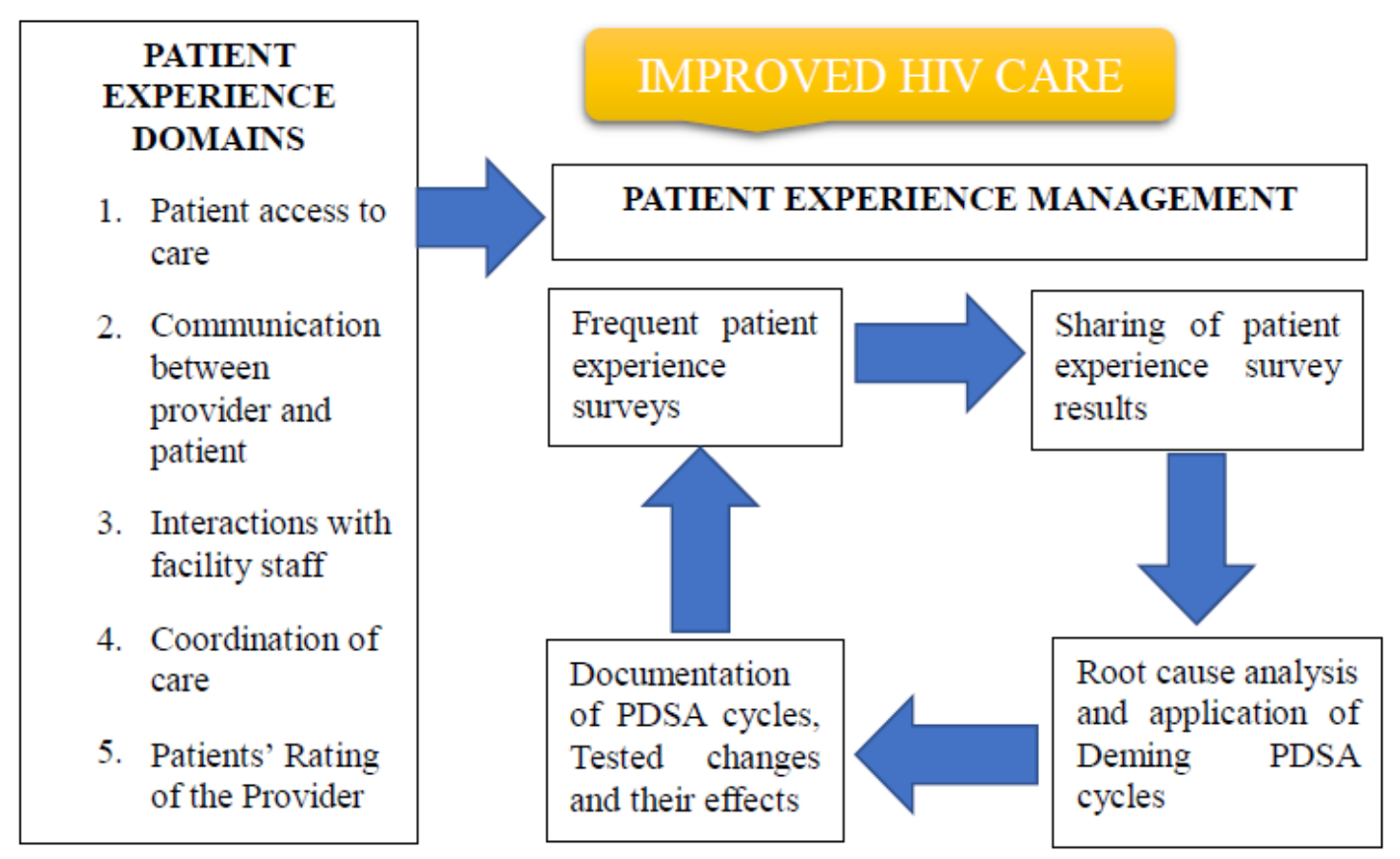

Figure 1. Conceptual Framework for Patient Experience Management to Improve HIV Care 


\section{Literature Review}

Globally, 36.7 million people are estimated to be living with HIV, and about 1 million AIDSrelated deaths occurred in 2016 alone, with SubSaharan Africa having more than half of the global burden. The UNAIDS 90-90-90 global targets were to accelerate progress such that, by $2020,90 \%$ of all people living with HIV are identified, of which $90 \%$ are put on Antiretroviral Therapy (ART) and of which 90\% are virally suppressed [5]. The Uganda Population-based HIV Impact Assessment (UPHIA) 2016/2017, [6] showed that the HIV prevalence had reduced from $7.3 \%$ as per the Uganda AIDS Indicator Survey 2011 [7] to 6.0\% among adults of 15 to 49 years of age. The report also estimated that 1.2 million people aged 15 to 64 and 95000 children below 15 years of age were living with HIV [6]. It is estimated that $62 \%$ of HIV positives were already in care [8] but only $56 \%$ were on treatment by June 2016 [9], of which by 2017 , only $45 \%$ and $65 \%$ were males and females, respectively [10].

\section{Adherence to Treatment, Appointment Keeping and Viral load Suppression among HIV Positives}

The success of HIV treatment is dependent not only on access to ART but also on retention in care and good adherence to treatment to achieve viral suppression, prevent virologic failure, reduce viral transmission, and HIV/AIDS-related deaths $[11,12]$. The optimal adherence to treatment to achieve viral suppression is noted to be $95 \%$. However, in a study conducted in India, it was observed that $9.5 \%$ of patients had poor adherence to HIV treatment of less than $80 \%$ [13]. In a study to determine the prevalence of adherence to treatment, patient self-reported adherence to HIV treatment of $50.4 \%$ was noted in Nigeria, associated with busy schedules of patients, simply forgetting to take their pills and religious constraints as major challenges to adherence [14].
Retention in care is one of the important indicators of a good HIV care program. A recent report by Uganda Virus Institute noted that only $50.2 \%$ of patients were retained on HIV treatment 12 months after ART initiation in 2018. It also observed that $26.6 \%$ of clients got lost from care during pre-HIV treatment in both rural and urban HIV clinics [15]. One study revealed an overall retention rate of $51.1 \%$ and a loss-to-follow-up of $52.9 \%$ in the first 6 months of ART initiation [16]. However, the lost to follow-up of clients in HIV care for newly enrolled pregnant and breast-feeding women was observed to be only $8.1 \%$ [17]. Retention of HIV clients in care is determined by regular and scheduled visits by the patients, and it is affected by missed appointments [18]. It is also important to note that adherence to clinic appointments is a predictor to adherence to treatment $[19,20]$. Studies have also shown a positive association of missing appointments with poor adherence to HIV treatment [21], failure to suppress viral load $[22,23]$, and drug resistance $[24,25]$. Other implications of missed appointments were noted to be increased costs in service provision and access and wastage of time for both the service provider and the client [26]. A 7\% of HIV clients in care missing their appointment in the last three months was observed [27]. Relatedly, a study in three settings of Cameroon observed that $49 \%$ of children in HIV care missed their appointment schedules, and this was attributed to longer follow-up appointments [28]. Contrary to that, only $1.8 \%$ of scheduled clients in a district-based hospital in Uganda missed their visits for refills in a period of 28 weeks of follow-up study [29]. The Uganda virus institute report 2018 noted that appointment keeping is one of the early warning indicators of HIV drug resistance being monitored by looking at the proportion of patients picking up all prescribed drugs on time before the previously prescribed and dispensed drugs have run out. The report further noted that $65.2 \%$ of patients keep their appointment at least within two days after the appointment date [30]. 
The ECASA Group of Consultants LTD in the Uganda AIDS Country Progress Report estimated that by June $2018,87 \%$ of people living with HIV and on treatment had viral suppression [31], which results were close to the $76.8 \%$ [32]. It was also observed that the likelihood of having viral non-suppression remained significantly lower among adolescents who had been on ART for more than 9 years [32]. A study conducted on 219 individuals in HIV care observed a $33.9 \%$ undetectable viral load [33], a 70\% re-suppressed after adherence interventions [34]. The re-suppression was noted to be only $23 \%$ after 3 sessions of intensive adherence counselling among children under 20 years of age [35]. Viral load monitoring to clients on treatment 12 months after initiation revealed $79 \%$ coverage [36].

\section{Patient Experience and Management Indicators}

\section{Patient Access to Care and Appointment Scheduling}

Patient access to health care means having "the timely use of health services to achieve the best health outcomes" [37]. Good access to care is defined by the undelayed but easy gaining of entry into the health care system and getting access to sites of care where patients can receive the needed services [38]. Patient appointment mechanism directly determines the "timeliness" of the health care service given [39] while scheduling for health care services is a complex issue that requires the balancing of clinical process, patient needs, and influencing the capacity of health systems to offer appointments in a timely manner [40]. Efforts to patient retention in care should be based on the measures to maintain the provider-patient relationship and to understand the nature of patients falling out of care. Maintaining an appointment list and tracking whether patients attended the clinic is one of the ways to improve appointment keeping. This approach is said to allow for a more systematic look at the group of patients who don't keep the appointment, so that resources are targeted to engaging them [41]. Generation of a list of patients who missed an appointment on a particular day is one of the strategies for tracking appointment keeping and reducing on the time lag between missed appointments and when efforts are put to bring the patient back to care [26]. The fact that missed appointments cost both time and revenue, application of a systems-thinking approach, improving the flow of work and removing wasteful processes, redesigning of clinic workplace, and formation of a multidisciplinary team, have been observed to improve appointment scheduling [40]. Studies have shown that using a mix of approaches such as pre-appointment reminder calls, regular updates of patients' phone numbers and addresses, and phone calls after a missed appointment improve on patient appointment keeping [42]. Peer to patient's relationship was noted to reduce facility-based barriers to appointment keeping [43] and provide targeted psychosocial support services to reduce missed appointments [44, 45].

\section{Waiting Time}

Patient waiting time remains a problem in today's healthcare systems because of the dynamic, complex, and emergent nature of healthcare systems, as patients frequently have negative experiences with healthcare waiting rooms [39]. Reduction of waiting time of patients needs a systematic breakdown of workflow processes and identify problem areas $[46,47]$. It is acknowledged that addressing waiting time is complicated as multiple stakeholders and operational processes are involved and interlinked. Delivering the best patient care was noted not to only rely on the clinical expertise of the health provider but also involves the interplay of the clinical setup, workflow, and communication. A project to improve the patient waiting time with revision of the appointment scheduling, patient reminders, more effective communication, and work reassignments, showed no improvement in waiting time due to fluctuating manpower, 
resources, and poor handover of patients from one provider to another within a visit but an increase in the percentage of patients seen by the doctor within a period, improvement in staff satisfaction and communication. However, poor appointment scheduling was noted to be a key component that contributes to delays and long waiting times for patients in outpatient clinics [47].

\section{Knowing where to Access Services and Communication between Provider and Patient}

Health care services are considered accessible when patients face no actual or perceived barriers to receiving services. It has been observed that supporting access to health care from the users' perspective helps patients to receive the right care at the right place and time. Integration of services, increasing staff numbers, expanding service delivery hours, reducing waiting times, and having systems for triaging patients, have been noted to improve access to care [48]. Communication between provider and patient aims at finding providers who meet the needs of individual patients and with whom patients can develop a relationship based on mutual communication and trust [38]. The domain is measured based on aspects of service provider listening carefully to the patient, explaining things in a way that is easy to understand, having respect for the patient, allowing enough time during the consultation, and providing adequate privacy during service delivery.

\section{Respecting what Patients say, Consultation Time and Service Provider Communication Skills}

While excellent clinical care remains the expectation, health care consumers are now seeking health care and supporting systems that respect patients [40]. It is observed that there is a need to involve patients in their own health and care such that service providers provide what matters to the patient, who are the experts of their own care. Shared decision-making was noted to be the process in which people who experience a change in their health work together with clinicians to select tests, treatment, management, and support packages [49].

The mismatch between the service provider and the patient during consultation, as the service provider is interested in making a diagnosis, while the patient focuses on the future actions of the service provider, is noted to exist [36]. It is, therefore, important that consultation meets the intentions of both the service provider and the patient. In a study to assess patients' satisfaction with a consultation at a general clinic in Saudi Arabia, it was observed that 53\% of the respondents were dissatisfied with it [50].

Patient experience has a series of complex healthcare processes, each comprised of numerous critical points of interaction between patients and the service provider. In a study to improve service provider's communication skills, the service provider's interpersonal skills were noted to be the most important in-patient experience. Patient satisfaction study of trained service providers and communication skills revealed that the proportion of "excellent" ratings of provider services increased, most notably; in the involving of patients in care decisions, explaining medical condition, the providers knowing the patient as a person, listening, and overall quality of care from the provider [51].

\section{Understanding Service Providers' Instructions and Interactions with Facility Staff}

It was observed that many patients leave their healthcare visit unsure of what their providers asked them to do or what was discussed, as only $12 \%$ of adult Americans have proficient health literacy, and only $30.1 \%$ of them could adequately teach-back [52]. It is known that other staff in the facility can influence the outcome of the patient's visit to the facility.

This is aimed at seeing other facility staff being supportive and helpful to patients, 
courteous, and respectful to the patients seeking care from the facility. Nonclinical and clinicalsupport personnel have a powerful influence on how patients perceive their entire care experience, just like the medical practices can improve the overall care provided by focusing on nonclinical and clinical-support services to create a strong first impression of patients at every care visit, to prepare clinical staff to deliver excellent service, minimizing needless delays in service delivery, and prioritizing the services that patients consider to be most important [53].

\section{Coordination of Care and Knowing Important Medical History}

Coordination of care is a conscious effort to ensure that all key information needed to make clinical decisions is available to patients and providers [38], and it is defined as the deliberate organization of patient care activities between two or more participants involved in a patient's care to facilitate the appropriate delivery of health care services, [54]. Studies indicate that over 80 percent of diagnoses are based on medical history [55], a powerful diagnostic technology [56]. It is suggested that a more rational approach to the use of the medical history led to improvements in diagnostic efficiency and effectiveness, with benefits for individual patient care [56].

\section{Medication Information}

Patients are reported not to understand the instructions they receive on medications, and 40-80 percent of the medical information communicated by health care practitioners is completely forgotten by the time they reach home [57]. Patients always have challenges in taking their medications as a result of; limited patient empowerment, mistrust of prescribed medications, and frequent noncommunication about medications prescribed. It was also noted that patient-centered care makes service providers view patients as partners in their disease management and therefore talk to patients about the prescribed medicines [58].

\section{Methodology}

The study was conducted in Jinja district Uganda, at Bugbee, Budondo, Walukuba, and Mudede health centres, purposively selected due to their high patient numbers. The study units were files of adult HIV clients identified with any of the poor HIV care outcomes of; missed appointments of $>$ two weeks, poor adherence to treatment of $<85 \%$, and unsuppressed viral load of $>1000$ viral copies per milliliter. Duration in care was one of the determinants for a client file to be considered for the study, as only clients who have been in HIV care for at least 6 months are eligible for a viral load test by the Uganda Ministry of health standards. Patients of the selected files above were also targeted for an interview as study units.

Lastly, the PDSA cycles at the study health facilities were also used as study units during the study. The sample size estimate of 226 was determined by the use of the hyper geometric method for a known population. Files of HIV active clients for the period of October to December 2018 were reviewed to identify any of the study HIV care outcomes, of which 437 were found to fit in the inclusion criteria. 224 clients for the identified files were interviewed at baseline in January 2019 and end-line assessment in July the same year.

The action research involved interventional, observational, descriptive, and qualitative study methods. Data collection was done in three parts; 1) the client-patient experience exit interviews using the Customer Assessment of Healthcare Providers Systems (CAHPS). This experience was determined by 14 elements on a Likert scare of 'Never,' 'Sometimes,' 'Usually,' and 'Always,' and 1 element of rating service providers on a scale of 1 to 10 , with 1 being the lowest, 2) the patient HIV care outcomes, and 3) the PDSA cycles, using the documentation journals. Monthly quality improvement 
meetings were held to share results and experiences among the study health units.

The data was analyzed using Microsoft excel, and results were shared with the 4 teams of health unit managers to conduct a root cause analysis of the findings at baseline and plan for improvement using journals to document the PDSA cycles. The baseline and end-line assessment findings are presented in tables and narratives with percentages of the various parameters of client experience and quality of care.

From the Likert scale of the patient experience measured indicators, results in percentages of respondents were analyzed and presented. Findings from the PDSA cycles were presented in a descriptive manner to give a picture of the interventions at the study sites. The study followed the professional codes of conduct for research, including observing subjects' right to privacy, confidentiality, and informed consent.

The study protocol was approved by Milldam Uganda Research and Ethics Review Committees (REC REF 0309-2018), and the Uganda National Council of Science and Technology (UNCST) (HS 2510). I declared not having any conflict of interest or relationship with the study sites, research, and ethics committee, and they had no influence in any manner that might have affected the validity of the study.

\section{Results}

\section{Demographics of the Study Client Files}

The study showed that $29.3 \%$, and $70.7 \%$ of client files identified with any of the poor HIV care outcomes were for males and females, respectively. The prevalence of the study HIV care outcomes at baseline was $13.6 \%$, with Bondo, Bugembe, Mpumudde, and Walukuba health centre having $7.3 \%, 14.8 \%, 13.4 \%$, and $17.9 \%$, respectively.

Most of the client files included in the study were for clients who had been in care for more than four years.

\section{Results on the HIV Care Outcome Indicators}

The findings show that a total of $52(11.8 \%)$ client files were identified with poor adherence to treatment at baseline assessment. Walukuba health centre having only $0.7 \%$ of its clients with a poor adherence score at baseline is uncommon, and it is possible that the assessment for adherence for the HIV clients in care was being done wrongly by the service providers, as at endline assessment, it was observed to be at $11.3 \%$. The study revealed that 285 (65.2\%) of the study files had more than two weeks of missed appointments, and a reduction to $88(25.1 \%)$, at end-line assessment. It was also observed that of the 285 client files of missed appointments for more than two weeks, $266(93.3 \%)$ had an adherence score of $>85 \%$ at baseline assessment.

The study revealed that at baseline assessment, $203(46.5 \%)$ of study client files were due to unsuppressed viral load, which reduced to $109(31.5 \%)$ at end-line assessment. It was also revealed that $142(70 \%)$ of all client files with unsuppressed viral load were for clients who had been in care for more than four years. $162(37.1 \%)$ of client files studied had undetectable viral load at baseline assessment, which improved to $181(51.7 \%)$ at end-line assessment. $34(7.7 \%)$ of the study files had never had a viral load test done to the clients at baseline assessment, which reduced to 5 (1.4\%) at end-line assessment. 30 (83.3\%) files of clients who have never been done a viral load at baseline assessment were between 6 months and 2 years in care. It was observed that $151(34.5 \%)$ of the study client files were overdue for a viral load test to be done at baseline assessment, which reduced to $59(16.8 \%)$ at end-line assessment. The study further showed that 192 (91\%) client files with unsuppressed viral load had adherence to a treatment score of $>85 \%$ at baseline assessment, which reduced to 47 $(42.2 \%)$ at end-line assessment. This could be pointing to resistance to HIV treatment, which is a challenging situation. 


\section{Results on the Patient Experience of HIV Care at the Study health Facilities}

The study identified 437 potential respondents based on the study selection criteria, out of which 224 were interviewed at both baseline and end-line assessments. Specifically, there were 44, 82, 45, 43 respondents for Budondo, Bugembe, Mpumudde, and Walukuba health centres at baseline, and 52, 64, 51, and 57 at end line assessments, respectively. For patient access to HIV care, there was an improvement on the percentage of respondents reporting that they "Always"; get appointment schedules from service providers, access HIV care service within four hours from arrival to exit and get to know where to access HIV care services within the health facility, from an averagely of $44.9 \%$ to $86.2 \%$. Secondly, there was an improvement in communication between service providers and the patients from the average of $57.6 \%$ to $92.4 \%$ of the respondents reporting that they are "Always"; listened to by the service providers, explained to in a way that is easy to understand, showed respect for what they say, given enough time during consultation, and adequate privacy during service delivery. The study results also showed an improvement in the patient experience domain of interactions between the patients and the facility support staff from an average of $54.8 \%$ to $88.4 \%$ of the respondents reporting that the support staff are "Always"; helpful, courteous, and respectful to patients. Fourthly, there was an improvement in the coordination of the HIV care from an average of $37.2 \%$ to $85.4 \%$ of the respondents reporting that their service providers are "Always"; knowing important information about the patients' medical history, getting someone from the service provider's room to follow patients up to the next service point, providing patients with all the prescribed service packages, and talking to patients about all the prescribed medicines. Lastly, the patients' improved satisfaction with the service provider for the services received from $28.3 \%$ to $50.5 \%$ of the respondents scoring "Excellent".

\section{The Effect of Application of the Deming PDSA Cycle as a Patient Experience Management Tool}

\section{Appointment scheduling in HIV care}

During the implementation of the study, it was observed that appointment keeping was a challenge, especially for Bugembe, Walukuba, and Mpumudde health centres. Patients used to come in any day and time for treatment, and anyone at the facility could prescribe and refill ART for the clients. At Mpumudde, some of the support staff, like the linkage facilitators, could at times supply more drugs than what is prescribed, and there was no harmonization of appointment dates with the drug supplies. Completing the HIV client card was a challenge to almost all the health centres, and it could be hard to know that important information or service offered to a client. Health managers were not concerned about what was happening in the clinics, and the linkage facilitators were serving clients out of sympathy. During the implementation of the project to improve on appointment keeping at all the study health facilities, health managers realized that they had left the leadership of the HIV clinics to lower cadres, and the quality of care was noted to be limited. At Mpumudde health centre, several meetings were held with the health facility managers to support them realize the areas of weakness, and this helped in a number of ways, including the allocation of more staff to the clinic. Using the Deming PDSA cycles, the following tested changes were used; all the study health facilities conducted harmonization of appointment date with drug supplies through pill counting of drug balances for the client to ensure that a client is supplied only enough for the next appointment date. The health managers also defined the roles of linkage facilitators to ensure that they do not prescribe or dispense drugs to clients. HIV clinic days were harmonized, and all clients were informed of the changes in the HIV clinic days such that other days were only for new HIV clients or those with complications 
to treatment. The creation of a box or space for files on appointments helped in the identification of those who have missed attending the clinic. This was followed by a phone call to the client who had missed the clinic the following day. Service providers also practiced on-spot documentation of the services offered to the clients in the HIV care card to avoid incomplete information capture, which could affect clinical decisions.

\section{Reducing Waiting Time for Patients during HIV Care}

Waiting time was noted as one of the major challenges being faced by HIV patients as they accessed care, especially at Walukuba, Bugembe, and Mpumudde health centres. The HIV clinics at the study sites were understaffed, yet the few service providers used to start clinics late, there was no order of service of first come, first serve, the laboratory services were a distance from the clinical rooms, and patients used to get lost within the facility. All these gaps were contributing to delayed access to services and, therefore, long waiting times for the patients. A number of change ideas were applied using the PDSA cycles to improve on the patient waiting time as follows; change in the client flow to reduce on unnecessary movements of both the clients and the service providers, provision of services in a one-stop centre for easy access to all the services, provision of fast come fast serve card to enable the early comers to access services first, increasing staff to provide services, identification of files for patients on appointment a day before the clinic day, pre-parking of drugs for clients before the clinic day, and ensuring early starting of the clinics. These practices were scaled to all the study health facilities, and they realized improvement in the patient experience with waiting time.

\section{Increasing Access to Services within the Clinic}

The service providers of Walukuba and Bugembe health centres were surprised to realize that some of their clients were not aware of where to access all the prescribed services. This was because there was one waiting area for all outpatients, which caused stigma and confusion to patients as to which room or service provider to see. The rooms for provision of services were not labelled for easy identification of the service sites, and service sites were distant, especially the laboratory and the pharmacy, and limited communication to patients on where to access the different services within the health facility. In an effort to improve the situation, and using the PDSA cycles, the service providers identified safe spaces for the HIV clients where all the services were provided during particular clinic days, and such spaces were also used for other services during non-HIV clinic days to reduce stigma. There was also labeling of the service points within the service areas for easy directions to the clients. Walukuba health centre, positioned the records assistant at the registration point to direct all clients to the next service point after registration.

\section{Listening Carefully to Patients Concerns}

During the study, clients of Walukuba and Bugembe health centres reported not being listened to "Always" by the services providers. The health managers attributed the situation to the allowing of support staff with limited training and skills to provide HIV care, uncoordinated patient appointments, and the poor leadership and management of the HIV clinics as service providers had organized absenteeism where a few service providers would be available for duty compared to the expected. The study supported the engagement of the health manager to create clinic days for the different categories of clients (differentiated HIV care) notably, the children, the adolescents, and the virally unsuppressed clients. Identification of a nurse to do triaging of HIV clients during clinic days such that all stable clients are served fast, and only the unstable clients could see the clinician, allocation of more staff during the clinic days to reduce the work 
pressure, and harmonization of appointment schedules were the strategies implemented to improve on the patient experience of being listened to during their visit to the service provider.

\section{Explaining Things to Patients in a Way that is Easy to Understand}

During the study, Walukuba health centre was reported to have service providers who do not always explain to patients in a way easy to understand during the baseline assessment interview compared to other study health facilities. It was noted by the health managers that Walukuba health centre had linkage facilitators who had little knowledge on some of the medical terms, yet they had much more interface with the patients than the quantified staff. It was also noted that the facility is in a community with mixed tribes and languages. The facility gets clients who do not understand the commonly used local languages in the area, and the service providers were not able to speak to them, hence the need for an interpreter. These factors affected this patient experience element, and in a way to improve, the health facility managers allocated more qualified staff to the HIV clinic to reduce the interface of the patients with the support staff. The managers also allocated a linguistic linkage facilitator to interpret for patients. The two interventions improved the situation at Walukuba health centre as the 'Always' response by the study participants on whether the service providers 'Always' explained things in a way and language easy to understand increased from $24.5 \%$ to $98.2 \%$ at baseline and end-line assessments respectively.

\section{Service Provider Respecting What Clients say during HIV Care}

Respecting of what patients say by the service provider is a right, and it maintains the dignity of the patient. During the study, respect for what clients say by the service providers was good at most of the study health facilities except at
Walukuba. Walukuba health centre service providers reported not having been aware that patients were not feeling comfortable with the limited respect of what they say during access to care. The findings prompted the health managers to hold a meeting to give feedback to all the service providers. It was also agreed that the service providers implement the communication of the patient experience rights to the clients during every clinic day. Patients gained the confidence to express their dissatisfaction during the exit interviews, and such feedback was being shared during the monthly quality improvement meetings. The study showed an improvement in the "Always" response to service providers showing respect to what patients say most, especially at Walukuba health centre, from $24.5 \%$ to $96.5 \%$ at baseline and end-line assessments, respectively.

\section{Service Provider Spending Enough Time with Clients during Consultation}

It was a fact that all the HIV clinics were understaffed and overcrowded as the facilities were running only one clinic day in a week. Under such a situation, it was hard for the service provider to spend enough time with the patients during consultation.

The interventions were an additional human resource to the clinics, the orientation of the new staff on the key aspects of the clinic running, and the splitting of the HIV clinics in a differentiated manner as the unsuppressed clients, children, and adolescents were being seen during their special clinic days. Bugembe health centre being with the biggest number of clients also split the general HIV clinic to run for two days in a week. These interventions worked for the health facilities and there was improved time for consultation.

\section{Improving Privacy for Clients during HIV Care}

HIV is a very stigmatizing and discriminating disease in Uganda, and this has affected access and utilization of HIV services. Privacy at 
Budondo and Walukuba health centres was grossly rated low by the majority of the respondents. This was attributed to the fact that general outpatients were mixed with the HIV clients during access to care. It was also a practice at Budondo and Walukuba health centres that HIV client files would be read by name in front of all the outpatients. It was also possible to see and hear the details of the service provider's discussion with the HIV client at Budondo health centre as the window for the clinician's room had no canteens, and the service point was just near the window.

At Mpumudde health centre, the sorting of files, recording, intensive adherence counselling sessions and dispensing was being done in the in-patient ward. All the in-patients were seeing and hearing all that was taking place. At Bugembe and Walukuba health centres, dispensing of drugs for the HIV clients was happening at the general dispensary, and it was hard to observe the privacy of the HIV clients. All these factors have compromised privacy and increased stigma at the health facilities. It had resulted in patients coming on non-clinic days and late in the evening when many of the outpatients have left the facility.

It also affected appointment keeping, adherence to treatment, and access to other services like family planning. At Budondo health centre, a new room was allocated for HIV care. The room was near the filling room for easy transfer of files and storage. Budondo and Walukuba health centres piloted the use of first come first serve cards with numbers. This eliminated the calling of clients by name to access services. Walukuba, Bugembe and Mpumudde health centres made the HIV clinics a one-stop centre with almost all the services in one area. The space for the clinic was closable for the general patients not to know what is happening in the clinic. This was a magic bullet to privacy as it reduced stigma improved the client's confidence, expression, and access to HIV service.

\section{Support Staff Helping and Respecting Clients during HIV Care}

Access to HIV care can be affected by the communication of the support staff to the patients. Lack of help and respect to the clients seeking care by the support staff creates a bad experience of the care. It is important that support staff are helpful and respectful to the clients seeking care to contribute to a good experience with the services received. At baseline assessment of patient experience, Walukuba and Bugembe health centres had lower percentages of the "Always" response of $24.4 \%$ and $50.9 \%$ compared to Mpumudde and Budondo health centres with $78.8 \%$ and $75.6 \%$, respectively. The health facility teams attributed it to the fact that the HIV clinics at the affected health facilities were mainly being run by the linkage facilitators, who are support staff. The linkage facilitators had taken on the roles of the qualified staff, yet they had no professional ethics to practice. At Bugembe health centre, the health managers redefined the roles of the linkage facilitators and limited their involvement in the roles of the qualified staff. At Walukuba, one of the notorious linkage facilitators was replaced with another one, and this improved the situation. It is also true that the addition of more qualified staff to the clinic also reduced the interface of the linkage facilitators with the clients. Budondo and Mpumudde also practiced the redefining of roles for linkage facilitators through meetings that involved the health managers, the HIV clinic service providers, and the linkage facilitators. It was also observed that the support staff became more respectful and courteous to patients during access to HIV care at all the study health facilities.

\section{Service Provider Knowing Important Information about the Client Medical History}

Studies indicate that over 80 percent of diagnoses are based on medical history. Reviewing and knowing the past medical history of an HIV client in care helps in the provision of 
quality HIV care services. It was revealed that the HIV clinics in the study health facilities were inadequately staffed, and this was affecting the time required for the service provider to review client cards to know important information of the client's medical history. It was also noted that the HIV service providers were not stable as health managers could rotate and switch service providers to different departments at any time. It was also true that the highly qualified and senior service providers were not interested in working in the HIV clinics, and they were also not attending refresher training on HIV care. At all the study health facilities, the nurses and linkage facilitators were the ones mainly managing the clinics. This was affecting the quality of HIV care provided and therefore making it hard for the service providers to review and have an adequate medical history of the clients under their care. The magic bullet to this problem was increased staffing into the HIV clinics and engagement of the health managers to allocate appropriate carders of service providers to the clinics. For example, Mpumudde allocated a clinical officer, a laboratory technician, and a nursing officer to the clinic, while Budondo allocated a medical officer, a clinical officer, and a nursing officer. Bugembe acquired two more nurses, while Walukuba added a nurse and a laboratory staff to the clinic. The strategy was noted to reduce the chances that a lower carder manages the HIV clinic. The strategy improved the "Always" response to service providers knowing important information about the patient's medical history above $90 \%$ at all the study health centres.

\section{Follow up of Clients to Next Service Points during HIV Care}

The study noted that follow-up of clients to the next service point was only being implemented by Mpumudde health centre, which attributed it to physical escort of the client to the different service points by the linkage facilitators. Other study health facilities also had linkage facilitators, but they were not being used to follow up clients to the next service points. It was also reported that the facilities were understaffed to have someone follow up on clients to the next service points. Bugembe, Walukuba, and Mpumudde health centres opted to have a one-stop centre for almost all the services such that the next service points are within the same room or area, and it was not necessary to escort a client but to direct him or her to the next service table by pointing. Budondo health centre did not opt for any of the interventions, and this affected their improvement on this element.

\section{Providing all the Prescribed Service Packages to Patients during HIV Care}

The problem of providing limited prescribed service packages almost affected all the study health facilities. The service packages that were noted by the health facility managers as affecting this element were drugs, and Viral load testing. Budondo, Walukuba, and Mpumudde health centres had a low viral load coverage as some patients for this service were waiting for long hours at the main laboratory. It was realized that some clients would leave the laboratory without getting the service but convince the dispensing staff that they have been bled for the test to access their drugs. Bugembe health centre had solved this through the engagement of the laboratory staff to give priority to clients for viral load, and the strategy was working for them. This is what Budondo health centre tried, and it also worked for them. Walukuba and Mpumudde health centres innovated to have the viral load bleeding site within the HIV clinic to avoid missed opportunities, and this was a very successful strategy for them. On the side of drugs, there was always adequate stocks of ARVs, and access was ensured. However, the facilities had limited supplies of drugs for opportunistic infections, especially Cotrimoxazole. Budondo health centre had enough of drugs for opportunistic infections as it was practicing good procurement and rationing of drugs. Walukuba and Bugembe health centres 
tried the same strategy, and it also worked for them. Mpumudde did not succeed as the mandate to order and store drugs was not in their hands, and the in-charge was not willing to support this arrangement. It can therefore be concluded that working as a team with the laboratory staff either to give priority to clients for viral load in the main laboratory or creating a bleeding site in the HIV clinic improves viral load coverage and access.

\section{Talking about the Prescribed Medications to Patients during HIV Care}

The knowledge of patients on the medications provided increases adherence to treatment and improves patient's participation fully in their care. The service providers agreed with the study results that they were not giving adequate information to clients about the prescribed medicines. This was attributed to the thinking that clients were familiar with the drugs they take, yet at times there was a change in the size, package, and color of the medicines. There were also instances where substitution and switching of drugs was being done but still with no adequate information given. This was affecting adherence to treatment, and at times clients would take from one type of ARVs that they are familiar with and leave the ones they are not familiar with. The health managers of Bugembe and Mpumudde health centres had not assigned a qualified staff to dispense instead, it was the linkage facilitators (support staff) dispensing. This could affect the level of information about medicines that could be given to the clients. At Walukuba health centre, dispensing was being done at a general pharmacy where all patients were getting medicines from, and health workers were too busy to give enough information to patients, coupled with the stigma that patients were facing during the dispensing time as HIV drugs are unique and packaged in plastic bottles. The same situation was at Mpumudde health centre as the dispensing window was facing the in-patient ward, and all in-patients would see and hear the instructions to the HIV clients during dispensing. To improve on the patient experience element of talking about the prescribed medicines, Walukuba and Mpumudde health centres made and implemented a health talk program on medicines during each clinic to remind clients on the drugs they take but also to give new changes in the HIV care and treatment. Bugembe and Mpumudde health centres put up a fulltime nurse to dispense drugs including giving full instructions on the medicines. There was a change in the dispensing area at Walukuba health centre as they transferred the HIV drug dispensary into the HIV clinic room to make HIV care a one-stop centre, while Mpumudde health centre resorted to dispensing within the dispensing room to reduce stigma during dispensing.

\section{Rating of Service Providers}

Picking an opinion on how the patient rates a service provider gives a picture on whether the patient appreciates the efforts of the service provider in providing a service, and it is also an indicator that the patient will adhere to the service provider's instructions or even come back for services next time based on the built trust. It is a measure of how satisfied the patient is with the services of the service provider. The study showed an improvement in the satisfaction rates with the service providers across all the health facilities.

\section{Discussion}

\section{HIV Care Outcomes of Adherence to Treatment, Missed Appointments and Viral Suppression}

The study revealed that females identified with poor HIV care outcomes were two times more than the males. This could be due to the fact that there are more HIV-positive females (65\%) in Uganda accessing HIV treatment than males (45\%) [10], even when the study did not determine the percentages of males and females on treatment at the study health facilities. It is therefore important that efforts should be geared 
towards men accessing HIV treatment in the study health facilities. Retention in care is important for a good HIV care program. The study showed an $80 \%$ retention in care during the 6 months of study. This was higher than the $50.2 \%$ retention on HIV treatment 12 months after ART initiation [15], respectively. The difference could be due to the periods of study, i.e., 6 months and 12 months in the two studies.

There was a $10.3 \%$ lost to follow during the 6 months of study, compared to the $26.6 \%$ observed among pre-HIV treatment clients in care at both rural and urban HIV clinics [15]. The findings are similar to the observed lost to follow within 6 months of treatment initiation that reduced as patients stayed longer in care [16]. However, it was observed that among pregnant and breast-feeding women, the lost to follow among newly enrolled HIV positives to treatment was as low as 8.1\%, [17]. Conclusively, the longer a patient stays in care, the less likely that he/she will get lost to followup, and therefore, the need for many efforts in early than late retention in HIV care.

The researcher did not come across data on the death rates of HIV-positive individuals in health facility clinics but observed a $1.3 \%$ death of the study clients during the 6 months period of study. This confirmed that retention in care is affected by death, among other factors. It was also hard to get data on the rate at which client files get lost with in the health facilities, which affects the quality of HIV care as the history of the patient cannot be traced. The study revealed a 3.4\% loss of files for clients studied within a period of 6 months. The loss of client files reflects a poor filling and patient information management system, and service providers need to come up with strong interventions to reduce on the loss of client files and records within the health facility.

There was no literature accessed on the possibility of having a poor HIV care outcome despite being in care for a longer duration. However, the study showed that more than 55\% of clients identified with a poor HIV care outcome mostly unsuppressed had been in care for more than 4 years. It can therefore be concluded that being in HIV care for a long time does not guarantee good HIV care outcomes. It is recommended that service providers continue supporting all clients to adhere to HIV treatment irrespective of their duration in care.

\section{Adherence to HIV Treatment}

Adherence to HIV treatment is very key in suppressing the viral load, and studies have shown a positive association of missing appointments with poor adherence to HIV treatment [21]. The study revealed that $11.8 \%$ of all the clients identified with poor HIV care outcomes had a poor adherence of $<85 \%$. The finding is almost similar to a study conducted in India that observed that $9.5 \%$ of patients had poor adherence to HIV treatment of less than $80 \%$ [13]. The study also observed that $93.3 \%$ of patients who had missed an appointment for more than two weeks were scored an adherence level of $>85 \%$. This is ridiculous, and it can be attributed to the knowledge gap and or noncommitted service providers to score patient adherence to treatment per national guidelines. The following change packages were used to improve adherence scoring and patient adherence to treatment using the Deming PDSA cycle; Mentorship to service providers on patient adherence scoring and documentation, Intensified health education and information on drugs supplied, and intensive adherence counseling to all patients with poor adherence. The interventions were noted to reduce poor adherence to treatment. Therefore, it is recommended that the above interventions, when implemented as a package, improve service providers' capacity to score adherence and patient adherence to treatment.

\section{Adherence to Appointment Schedules in HIV Care}

It is important that patients keep their appointment schedules if adherence to treatment is to be ensured. The study revealed that $65.2 \%$ 
of the studied client files at baseline were due to missed appointments for more than two weeks in the previous three months. The period of missed appointments for at least two weeks in the studied client file was taken by the researcher to cater for such common practices of service providers not taking into account of cumulative pill balances from previous patient refills. The findings were close to the observed $49 \%$ [28], but too high to the $7 \%$ of [27]. The difference could be as a result of the differences in the period of review for the status of missed appointments, the duration of the missed appointment, and the age category of clients studied. During a root cause analysis of the causes of missed appointments at the study sites, the service providers identified that clients were having cumulative drug balances during their visits, and service providers were not doing pill counting to ensure that the drugs given balance with the date of appointment. The cumulative balance could make patients not keep appointments since they would not see the reason for coming back to the health facility. The clients were therefore being scored with good adherence, yet they did not keep the appointment as evidenced by the $93.3 \%$ who missed appointment but were scored a good adherence across all the study facilities at baseline. The service providers also observed that some clients were coming for treatment any time and day, including weekends, and this could affect the documentation of the services provided in the client record cards and registers as some working spaces and individuals may not be available or accessible. The third factor that was affecting appointment keeping was that some clients would get excess drugs through the health facility support staff without documentation and consent of the technical service providers. Lastly, there was a systemic failure of timely documentation and update of the client records. All these were the service provision challenges on adherence to appointment schedules across all the study health facilities. There was no literature accessed by the researcher that noted the above as some of the challenges to appointment keeping, but the available information was related to patient and community factors only.

To improve appointment keeping, the project used a systems-thinking approach to improve workflow, redesigned the clinic workplace, and used a multidisciplinary team [40] because using a mix of approaches such as pre-appointment reminder calls, regular update of patients' phone numbers and addresses, and phone calls after a missed appointment improve on patient appointments keeping [42]. The change package used to reduce on missed appointments were Pill counting to harmonize the pills supplied with the appointment date, Emphasis on strict appointment keeping for patients and duty attendance of the service provider during the clinic days, post missed appointment follow up phone calls to patients, Timely recording and updating of the client information required, and Engagements of the health facility managers to increase staffing of the HIV clinics. However, the end-line assessment results did not show much reduction in the percentage of client files with both missed appointments of more than two weeks and an adherence score of $>85 \%$ from $93.3 \%$ to $60.3 \%$. This means that the intervention of mentorship to service providers on patient adherence scoring and documentation had less effect on adherence scoring and or oversupply of drugs compared to the appointment schedules. It is therefore recommended that the study sites need to review the problem to identify other root causes such as multiple site visits by the clients and develop interventions to close the gap.

\section{Viral Suppression in HIV Care}

The ultimate goal of HIV treatment is to achieve viral suppression among patients. The third ambitious target for Uganda as adopted from UNAIDS is to achieve a $90 \%$ viral suppression by 2020 among HIV clients on treatment. Poor viral suppression leads to increased chances of developing resistance to 
treatment, opportunistic infection manifestations, HIV transmission, and eventually death. Baseline assessment results showed $46.5 \%$ of the client files identified with any of the study poor HIV care outcomes being due to unsuppressed viral load of $>1000$ copies $/ \mathrm{ml}$. The results do not match with the $13 \%$ unsuppression among the total clientele of the HIV clinic [32], compared to study results based on clients who had any of the poor HIV care outcomes studied. The findings agree that re-suppression occurs after adherence interventions [34] [35], as it was found out that only $31.5 \%$ of the study client's files were still with unsuppressed results at the end line assessment. The study also revealed that only 7.7 of the study files had never been done a viral load test at baseline assessment, which reduced to $1.4 \%$ at end-line assessment. The viral load test coverage is in agreement with the $75 \%$ coverage in 2017 [31]. The study further revealed that $70 \%$ of all the unsuppressed client files studied were for clients who had been in care for more than four years. This may be interpreted that the more a client stays in care, the more likely it is that he/she will turn unsuppressed. These findings are contrary to those from Cambodia that stated that the likelihood of having viral non-suppression was significantly lower among adolescents who had been on treatment for more than 9 years [32]. The difference could be related to differences in the health care systems in the two countries but also in the age categories studied. The rate of undetectable viral load among the study files was only $37.1 \%$, at baseline assessment similar to the $33.9 \%$ undetectable rate for viral load [33]. The undetectable viral load rate among the study files at the end line assessment improved to $51.7 \%$.

The study also observed that $83.3 \%$ of the client files expected to have had viral load monitored, and with results, the respective HIV patients had never been done any viral load test between the period of 6 months and 2 years. The study further observed that $34.5 \%$ of the study client files were overdue for a viral load test to be done based on the Ugandan Ministry of health standards. However, this was reduced to $16.8 \%$ at end-line assessment. The findings at both baseline and end-line assessments are similar to the observed $21 \%$ of HIV-positive clients who were due for viral load 12 months after initiation to treatment but did not have it done [36]. The effect of the observed gap leads to poor HIV care as the right decisions are delayed to be made. Health facilities need to have a mechanism of ensuring that all clients due for viral load access the service. It is also common for patients who are due for viral load testing missing the service even when they make a visit to the clinic. The study also showed that $91 \%$ of client files with unsuppressed viral load had adherence to treatment score of $85 \%$ and above at baseline assessment, which reduced to $42.2 \%$ at end-line assessment. This could be pointing to resistance to HIV treatment, which is a challenging situation. During the study, it was noted by the service providers that efforts to address challenges to viral load suppression were limited. To note; there was limited access to viral testing, late return of viral load test results, documentation of the viral load results in the client care cards was inadequate, documentation of intensive adherence counselling sessions was not effective, and timeliness of the sessions was not as per the ministry of health standards that guide that each session should be conducted one month apart.

The change packages tested to improve viral load suppression were Assigning of staff responsible for viral load, creating a viral load bleeding area within the HIV care site, timely tracking of patients for viral load testing and results, provision, and documentation of intensive adherence counselling sessions to HIV clients with unsuppressed viral load. The intervention resulted into a reduction in the number of clients with unsuppressed viral load among the study clients, as at baseline assessment, there was $46.5 \%$ of the study client files with an unsuppressed viral load of $>1000$ 
copies $/ \mathrm{ml}$, which reduced to $31.5 \%$ at end-line assessment. It is therefore recommended that service providers need to implement the above strategies as a bundle to ensure re-suppression.

\section{Patient Experience Management}

Patient experience has not been used as a means of assessing the quality of care in Uganda yet, if implemented, it leads to a memorable event in patients. It is important to note that patient care requires multiple practitioners during service provision, causing communication differences variations in protocols and approaches. It is therefore important to note that patient experience is beyond the patient-clinician interaction but the whole health care system.

Patient Experience Management has been used to close gaps in patient care especially for chronic conditions like HIV, and it creates a model of attention focused on the patient experience to accomplish the "Wow" effect in patient's access to health care. There has been challenges in patient experience management before of resistance to change, other organizational priorities, lack of support from senior staff, and limited resources. There is limited literature on how patient experience management has been used to improve patient centered care.

Therefore, this study adopted the Deming PDSA cycle approach because it is the most commonly used quality improvement approach in healthcare, and it uses a rapid cycle process, the Plan Do Study Act cycle, to test the effects of small changes in a short time using a systematic and data-driven approach to implement, test, and sustain changes.

\section{Improving Appointment Scheduling and Reducing Waiting Time for Patients during HIV Care}

It was observed that appointment keeping was a challenge, and health facility teams used different interventions like; Harmonization of HIV clinic days and appointment date with drug supplies through pill counting, timely documentation of appointment schedules, line listing clients, and identifying those who miss appointments schedule in an effort to bring the patient back to care, and patient re-engagements and similar observations have been made before [26].

Scheduling for health care services requires the balancing of clinical process, patient needs, and influencing the facility health systems to offer appointments in a timely manner [40]. It was in a similar way observed during the implementation of the above strategies to improve appointment scheduling.

Waiting time was noted to be one of the major challenges faced by HIV patients as they accessed care and a number of change ideas that were used to improve on it include a change in the client flow, creation of a one-stop centre for HIV care, and increased staffing. Although the interventions above worked well for the study health facilities, they did not show improvement in waiting time but improved staff satisfaction and communication [47]. This could be attributed to differences in the settings under which the studies were conducted.

\section{Increasing Access to Services within the Clinic and Listening Carefully to Patients Concerns}

Health care services need to be accessible to patients at the facility without any physical or perceived barriers. During the study, it was observed that the waiting area for some outpatients were contributing to stigma to patients during access to HIV services. The rooms for provision of services were note labelled for easy identification of the service sites. The laboratory and the pharmacy were a distance away from the clinical rooms, yet there was limited information to patients on where to access the different services within the health facility. The following tested change packages were used to improve patient access to services within the health facilities; Provision of services in a one-stop centre, labeling of the service 
points for easy directions to the clients, Designation of staff to triage patients and direct them to the next service points.

The study showed that the majority of the HIV patients at Walukuba and Bugembe health centres were not "Always" listened to by the services providers. Listening carefully to patients by the service provider improves the trust of the patient that his/her medical and psycho-social issues will be well understood and taken care of. The interventions to the observed situation were Creating separated clinic days for the different categories of clients, notably the children, the adolescents, and the virally unsuppressed clients, additional clinic staffing to reduce work pressure, and harmonization of appointment schedules with the created clinic days.

\section{Explaining Things to Patients in a Way that is easy to Understand and Service Provider Respecting what Clients say during HIV Care}

Walukuba health centre was observed not to be explaining things to patients in a way easy to understand at baseline assessment as it had its support staff (linkage facilitators) with many interfaces with the patients than the qualified. The health teams at this facility implemented the following tested changes to improve on the situation; Additional staffing of the clinic to increase on service providers interface with patients and allocation of an interpreter for clients with languages not known by the service

\section{References}

[1] Moen D. Ronald and Clifford L. Norman, (2010). Circling back. Clearing up myths about Deming cycle and seeing how it keeps evolving. https://deming.org/wpcontent/uploads/2020/06/circling-back.pdf.

[2] Bita Kash1* and Molly McKahan (2017). The Evolution of Measuring Patient Satisfaction. Journal of Primary Health Care and General Practice. provider. The tested changes were in conformity with [36] observation that "excellent" ratings of the service provider increased when patients were involved in care decisions.

\section{Conclusion}

The improvement in the HIV care outcomes using patient experience management is hinged on improved health facility leadership and governance, skilled human resources, and client flow in a one-stop centre mode. The ministry of health needs to support the implementation of patient experience management for improved HIV care in resource-limited settings. The healthcare system of any resource-limited system needs to ensure that leadership and governance at the health facilities need to be strengthened as they are critical in improving patient HIV care. Health facilities need to have adequate and competent service providers to run the HIV services to improve on the quality of care and patient experience with the services provided.

\section{Acknowledgement}

The following are acknowledged for their great contribution towards the success of this study; Prof: Everd Bikaitoha Maniple, Dr. Dyogo Nantamu, TAU team, Mildmay Research, and Ethics Committee, the Uganda Nation Council for Science and Technology, research assistants, health facility teams, and my family members.

[3] Wolf, Jason A., Niederhauser, V. Marshburn, Dianne and LaVela, Sherri L. (2014). "Defining Patient Experience," Patient Experience Journal: Vol. 1: Iss. 1, Article 3.

[4] Jackson, J. L., Chamberlin, J., \&Kroenke, K. (2001). Predictors of patient satisfaction. Social Science and Medicine, 52(4), 609-620. Doi:10.1016/S0277-9536(00)00164-7.

[5] Sophie Barton-Knott, (2017). The GENEVA/PARIS, 2017-UNAIDS new report. 
https://www.unaids.org/en/resources/presscentre/pre ssreleaseandstatementarchive/2017/july/20170720_P R_Global_AIDS_Update_2017.

[6] Musinguzi Joshua Ministry of Health, Uganda. (2019) Uganda Population-based HIV Impact Assessment (UPHIA) 2016-2017: Final Report. Kampala: Ministry of Health; July 2019. http://www.afro.who.int/sites/default/files/201708/UPHIA\%20Uganda\%20factsheet.pdf.

[7] Musinguzi Joshua. MoH (2012), Uganda AIDS Indicator Survey 2011. http://health.go.ug/docs/UAIS_2011_REPORT.pdf.

[8] Kambugu A.D (2016). Test and treat in Uganda: Perspectives from An Implementing/Academic Partner, Infectious Diseases Institute Makerere University College of Health Sciences. Southern African HIV clinicians' society, $3^{\text {rd }}$ biannual conference April 2016.

[9] Mobye K Anthony, and MoH (2016). Consolidated guidelines for HIV prevention, and treatment in Uganda 2016. https://differentiatedservicedelivery.org/portals/0/ad am/content/hvpzrp5yuusdpce $2 \mathrm{~m} 0 \mathrm{kmdq} /$ file/consolid ated $\% 20$ guidelines $\% 20$ for $\% 20$ prevention $\% 20$ and $\%$ 20treatment $\% 20 \mathrm{of} \% 20$ hiv\%20in\%20uganda.pdf.

[10]UNFPA (2017). Uganda, the status of HIV prevention in 2017. Where are we in the fight against HIV. UNFPA Technical Division SRHB May 2017. https://uganda.unfpa.org/sites/default/files/pubpdf/Uganda_Status\%20of\%20HIV\%20Prevention.p df.

[11]Fonsah JY, Njamnshi AK, Kouanfack C, Qiu F, Njamnshi DM, Tagny CT, et al. (2017) Adherence to Antiretroviral Therapy (ART) in YaoundeÂCameroon: Association with Opportunistic Infections, Depression, ART Regimen and Side Effects. Plos One 12(1): e0170893. DOI: 10.1371/journal.pone.0170893.

[12]Bach Xuan Tran1*, Long Thanh Nguyen2, Nga Hoang Nguyen3, Quynh Van Hoang1 and Jongnam Hwang. Determinants of antiretroviral treatment adherence among HIV/AIDS patients: a multisite study.

[13]Bharatesh D. Basti, ${ }^{1}$ Venkatesha Mahesh, ${ }^{2}$ Dattatreya D. Bant, ${ }^{3}$ and Geeta V. Bathija (2017). Factors affecting antiretroviral treatment adherence among people living with human immunodeficiency virus/acquired immunodeficiency syndrome: A prospective study. Journal of family medicine and primary care.

[14] Oku O. Afiong, Eme T. Owoaje, Oboko O. Oku and Emmanuel Monjok (2014). Prevalence and Determinants of Adherence to Highly Active AntiRetroviral Therapy Amongst People Living with HIV/AIDS in a Rural Setting in South-South Nigeria. African Journal of Reproductive Health March 2014; 18(1): 134.

[15] Nyakato P, Kiragga AN, Kambugu A, et al. Correction of estimates of retention in care among a cohort of HIV-positive patients in Uganda in the period before starting ART: a sampling-based approach. BMJ Open 2018;8: e017487. doi:10.1136/ bmjopen-2017-017487.

[16] Mugisha Kenneth, Andrew Ocero, Edward Semafumu, Luigi Ciccio, Roland F. Muwanika, James Otim, Med Makumbi, (2009). Retention of HIV Positive Persons in Antiretroviral Therapy Programs in Post-Conflict Northern Uganda-Baseline Survey of 17 Health Units.

[17] Musomba R, Frank Mubiru, Shadia Nakalema, Hope Mackline, Ivan Kalule, Agnes N. Kiragga,1

Rosalind Parkes Ratanshi,1,2, and Barbara Castelnuovo. Describing Point of Entry into Care and Being Lost to Program in a Cohort of HIV Positive Pregnant Women in a Large Urban Centre in Uganda. Hindawi AIDS Research and Treatment, Volume 2017, Article ID 3527563, 6 pages https://doi.org/10.1155/2017/3527563.

[18]Elizabeth Horstmann, Jillian Brown, Fareesa Islam, Johanna Buck, and Bruce D. Agins, (2010). Retaining HIV-Infected Patients in Care: Where Are We? Where Do We Go from Here? Clinical Infectious Diseases 2010; 50:752-761.

[19] Park WB, Choe PG, Kim SH, Jo JH, Bang JH, Kim HB, Kim NJ, Oh M, Choe KW: One-year adherence to clinic visits after highly active antiretroviral therapy: a predictor of clinical progress in HIV patients. J Intern Med 2007, 261(3):268-275. [20] Smith E. O., J. D. Curb, and R. J. Hardy, "Clinic attendance in the hypertension detection and followup program," Hypertension, vol. 4, no. 5, pp. 710715,1982 . View at Google Scholar View at Scopus. 
[21]Nemes MI, Carvalho HB, Souza MF, (2004). Antiretroviral therapy adherence in Brazil. AIDS. https://www.ncbi.nlm.nih.gov/pubmed/15322479.

[22]Lucas GM, Chaisson RE, Moore RD, (1999). Highly active antiretroviral therapy in a large urban clinic: risk factors for virologic failure and adverse drug reactions. Ann Intern Med; 131(2):81-87.

[23] TenoRes Study Group (2016). Global epidemiology of drug resistance after failure of WHO recommended first-line regimens for adult HIV-1 infection: a multicentre retrospective cohort study. Lancet Infect Dis. 2016 May;16(5):565-575.

[24] Sethi A, Celentano D, Gange S, Moore R, Gallant J. Association between adherence to antiretroviral therapy and human immunodeficiency virus drug resistance. Clin Infect Dis 2003; 37(8):1112-1118.

[25] Gupta RK, Gregson J, Parkin N, Haile-Selassie

H, Tanuri A, Andrade Forero L, Kaleebu P, Watera

C, Aghokeng A, Mutenda N, Dzangare J, Hone S, Hang ZZ, Garcia J, Garcia Z, Marchorro P, Beteta E, Giron A, Hamers R, Inzaule S, Frenkel LM, Chung MH, de Oliveira T, Pillay D, Naidoo K, Kharsany A, Kugathasan R, Cutino T, Hunt G, Avila Rios S, Doherty M, Jordan MR, Bertagnolio S. HIV-1 drug resistance before initiation or re-initiation of first-line antiretroviral therapy in low-income and middleincome countries: a systematic review and metaregression analysis. Lancet Infect Dis. 2018 Mar;18(3):346-355.

[26] Moore CG, Wilson-Witherspoon P, Probst JC, (2001). Time and money: effects of no-shows at a family practice residency clinic. Fam Med 2001; 33(7):522-527.

[27] Shumba c., L. Atuhaire, R. Imakit, R. Atukunda, and P. Memiah. Missed Doses and Missed Appointments: Adherence to ART among Adult Patients in Uganda. Hindawi Publishing Corporation, ISRN AIDS, Volume 2013, Article ID 270914, 7 pages, http://dx.doi.org/10.1155/2013/270914.

[28]Bigna Jean Joel R, Jean Jacques N Noubiap, Claudia S Plottel, Charles Kouanfack1, and Sinata Koulla-Shiro, (2014). Factors associated with nonadherence to scheduled medical follow-up appointments among Cameroonian children requiring
HIV care: a case-control analysis of the usual-care group in the MORE CARE trial.

[29] Setor Kunutsor,1 John Walley,1 Elly Katabira,2 Simon Muchuro,2 Hudson Balidawa,3 Elizabeth Namagala,3, and Eric Ikoona3, (2010). Clinic Attendance for Medication Refills and Medication Adherence amongst an Antiretroviral Treatment Cohort in Uganda: A Prospective Study. Hindawi Publishing Corporation AIDS Research and Treatment Volume 2010, Article ID 872396, 8 pages doi:10.1155/2010/872396.

[30]Uganda Virus Research Institute (2018). National HIV Drug Resistance Prevention, Monitoring and Surveillance Activities, National Status Report 2018.

[31]ECASA Group of Consultants LTD, (2018). Uganda AIDS Country Progress Report July 2017June 2018.

[32] Kolab Chhim1, Gitau Mburu2, Sovannary Tuot1, Ratana Sopha1, Vohith Khol3, Pheak Chhoun1 and Siyan (2018). Factors associated with viral non-suppression among adolescents living with HIV in Cambodia: a cross-sectional study. AIDS Research and Therapy. 15:20. https://doi.org/10.1186/s12981-018-0205-z.

[33] Katharina Kranzer, Stephen D. Lawn, Leigh F. Johnson, Linda-Gail Bekker, and Robin Wood, (2014). Community viral load and CD4 count distribution among people living with HIV in a South African township: implications for treatment as prevention. Europe PMC Funders Group. J Acquir Immune Defic Syndr. 2013 August 1; 63(4): 498-505. doi:10.1097/QAI.0b013e318293ae48.

[34] Bonner K, et al. Viral load monitoring as a tool to reinforce adherence: a systematic review. J Acquir Immune Defic Syndr. 2013;64(1):74-8.

[35]Nasuuna Esther, Joanita Kigozi1, Lillian Babirye, Alex Muganzi, Nelson K. Sewankambo and Damalie Nakanjako, (2018). Low HIV viral suppression rates following the intensive adherence counseling (IAC) program for children and adolescents with viral failure in public health facilities in Uganda. Nasuuna et al. BMC Public Health (2018) 18:1048. https://doi.org/10.1186/s12889-018-5964-X. 
[36] Martin Fischer and Gill Ereaut, (2012), Report: when doctors and patients talk: making sense of the consultation. The health foundation inspiring improvement.

[37] Institute of Medicine (1993). Committee on Monitoring Access to Personal Health Care Services. Access to health care in America. Washington, DC: National Academy Press; 1993.

[38]Agency for Healthcare Research and Quality (2011). National healthcare disparities report 2011.AHRQ Publication No. 12-0006 March 2012

[39]Sergei Savin, (n.d), Managing patient appointments in primary care. Graduate School of Business, 404 Uris Hall, Columbia University, New York, NY 10027.

[40]Lisa Brandenburg, Patricia Gabow, Glenn Steele, John Toussaint, and Bernard J. Tyson*(2015) Innovation and Best Practices in Health Care Scheduling. Institute of Medicine of the National Academies.

[41] Mallinson RK, Relf MV, Dekker D, Dolan K, Darcy A, Ford A, (2005). Maintaining normalcy: a grounded theory of engaging in $\mathrm{HIV}$-oriented primary medical care. ANS Adv Nurs Sci 2005; 28(3):265-277.

[42] Sendzik D. (2004) Retaining HIV-positive patients in care. In: Program and abstracts of the XV International AIDS Conference (Bangkok, Thailand). [43] Bradford J, Coleman S, Cunningham W. (2007). HIV System Navigation: an emerging model to improve HIV care access. AIDS Patient Care STDS. [44] Wohler-Torres BA, Valverde EE, AndersonMahoney P, Barragan M, Loughlin A, Metsch LR, (2002). System barriers to HIV medical care appointment compliance: results of the artas study. In: Program and abstracts of the XIV International AIDS Conference (Barcelona, Spain).

[45] Calsyn RJ, Klinkenberg WD, Morse GA, Miller J, Cruthis R, (2004). Recruitment, engagement, and retention of people living with HIV and cooccurring mental health and substance use disorders. AIDS Care.

[46] Niamat Ullah Ibne Hossain, Hunter Debusk, Md Mahmudul Hasan, Raed Jaradat, Mahmoud T. Khasawneh, (2017), Reducing Patient Waiting Time in an Outpatient Clinic: A Discrete Event Simulation
(DES) Based Approach, Abstract ID: 2220. Proceedings of the 2017 Industrial and Systems Engineering Conference K. Coperich, E. Cudney, H. Nembhard, eds.

[47] Emily Tse Lin Ho (2014), Improving waiting time and operational clinic flow in a tertiary diabetes center. BMJ Quality Improvement Reports 2014; u201918.w1006 doi: 10.1136/bmjquality. u201918.w1006.

[48]PHCPI (Primary Health Care Performance Initiative), (2018), improvement strategies model for access and timeliness. Version 1.0: Updated October 2018.

[49] NHS England, (n.d). Involving people in their own health and care: Statutory guidance for clinical commissioning groups and NHS England.

[50]Abdullah Khlofh Tabekhan1, Yahia Mater Alkhaldi, Abdullah Khalufah Alghamdi, (2018), Patient's satisfaction with consultation at primary health care centers in Abha City, Saudi Arabia. King Khalid University, Abha, Saudi Arabia.

[51]Kennedy, Denise M. MBA; Fasolino, John P. MD; and Gullen, David J. MD (2014) "Improving the patient experience through provider communication skills building,"Patient Experience Journal: Vol. 1: Iss. 1 , Article 10. Available at: http://pxjournal.org/journal/vol1/iss1/10.

[52]Agency for Healthcare Research and Quality (2019). More effort is needed to ensure pateints understand doctor's instructions. https://www.ahrq.gov data spotlight-health-literacy [53] Leonard L. Berry, Katie A. Deming, and Tracey S. Danaher, (2018). Improving Nonclinical and Clinical-Support Services: Lessons from Oncology. Mayo Foundation for Medical Education and Research. Published by Elsevier Inc.

[54] Shojania K, McDonald K, Wachter R, et al (n.d). Closing the quality gap: a critical analysis of quality improvement strategies - Volume 7.

[55]PSIC (Professional Solutions Insurance Company), (2011), Why the Patient History Is So Important. issue 4 of 2011.

[56] Nick Summerton (2008). The medical history as a diagnostic technology. British Journal of General Practice. DOI: 10.3399/bjgp08X279779. 
[57] Institute of Medicine (2014. Facilitating patient understanding of discharge instructions: Workshop summary. Washington, DC: The National Academies Press.

[58] Tanya Bezreh, M Barton Laws, Tatiana Taubin,
Dena E Rifkin, and Ira B Wilson, (2011). Challenges to physician-patient communication about medication use: a window into the skeptical patient's world. Health Services Policy and Practice, University of California-USA. 


\title{
Impact of Communication in the Management of Revenue Collection in Onitsha Metropolitan Area, Anambra State of Nigeria
}

\author{
Joseph Brown \\ Department of Management, Texila American University, Guyana City, Guyana
}

\begin{abstract}
The government needs adequate financial resources to deliver its many developmental functions. However, such financial resources are either not available or inadequate. One way of rising to this challenge has been scaling up revenue collection from local revenue sources. This study aims to assess the impact of communication in the management of revenue collection using a descriptive survey research design. The researcher formulated two research questions and one hypothesis. A selfdeveloped questionnaire was used for data collection. The sample size consists of revenue collectors in Onitsha Metropolitan Area selected using the purposive random sampling technique; subsequently, thirty copies of the questionnaire were administered by the researcher. Mean, and standard deviation was used to analyse the data. The study showed, among other findings, that communication facilitates the co-ordination of the task, which impacts the management of revenue collection. Also, there is no significant difference on the views of male and female revenue collectors regarding the impact of communication on the management of revenue collection in the Onitsha Metropolitan Area of Nigeria. These findings have the vantage of providing the researchers, policymakers, and government with adequate and correct baseline data on the impact of communication in the management of revenue collection. Conclusions were drawn from the findings, and it was recommended that training and re-training programmes for the revenue officials should be organized at regular intervals to enable them to meet the challenge of the new millennium.
\end{abstract}

Keywords: Communication, Management, Metropolitan Area, Revenue collection.

\section{Introduction}

Onitsha can be sited in Anambra, a State which came into existence in 1976 as one of Nigeria's 36 states and one of the 5 states in the country's southeast geo-political zone asides Imo, Ebonyi, Abia, and Enugu. Due to enormous political and administrative factors, Anambra State was extensively restructured in August 1991 and its former capital, Enugu, was created as a new state while Awka then became the new capital of Anambra State with 21 administrative local governments headquarters. Onitsha is a densely populated and rapidly growing merchandising city in Anambra State. Geographically, it is located on latitude $6.1^{\circ} \mathrm{N}$ and longitude $6.8^{\circ} \mathrm{E}$, and it serves as the major entry point when trying to access the eastern sector of Nigeria when coming from Lagos via Benin on the east-west highway and which as well connects the eastern north-south trail across Onitsha Niger Bridge. The city occupies the eastern bank of the Niger River, which stretches over 50 square kilometers.

The major concentration is in population, industrial activities, the areas showing the greatest potential for growth and huge revenue generation. Despite the high density of people and business activities in the Onitsha Metropolitan Area, the state continues to face major revenue collection challenges that make the government to lose billions of revenues 
annually $[1,2]$. Yuliaty identified that effective use of organizational communication in revenue collection functions is a major problem hindering the government to expand its revenue collection activities [3].

\section{Concept of Communication}

Communication involves any medium that is utilised to exchange information in an effective manner. For communication to be effective, there must be a sender (the initiator of the message), a recipient (the receiver of the message), and the verbal or non-verbal content (including signals, scripting, diagrams, and expressions) must be meaningful and clearly understood by the receiver with a minimal level of distortion [4]. More simply, communication is said to be "the creation and exchange of meaning" [5]. In spite of the fact that communication seems quite easy, yet there are several underlying factors such as the receiver's cultural background, the emotions coupled with the transmission, and the environment within which the medium was initiated.

Most of such complexities actually play a very vital role for an effective, skillful, accurate, and unambiguous message relay by revenue collectors in administering their tasks.

\section{Concept of Revenue}

Revenue is the incoming proceeds generated from normal business operations, calculated as the average sales price times the number of units sold. It may also be inferred to as the top line (or gross income) figure from which costs are subtracted to determine net income [6]. Revenue may also be identified as the sales return on an income statement. It is, actually, the value of all sales of goods and services recognized by a company within a specific period. Revenue, also referred to as Sales or Income basically forms the beginning of a company's income statement and is often considered the "Top Line" of a business. There are, however, numerous concept definitions of revenue. Fayemi briefly described government revenue as government proceeds which the legislature has a mandate to appropriate. Furthermore, he classified recurrent and capital revenue as two kinds of government income [7]. Hepworth depicted revenue as an income or funds generated to finance an item of expenditure. He portrays revenue as the means required to provide government services. He stated further that Income and Expenditure might also be classified as the dual aspects of finance, which are, primarily, the sources of fund and utilization [8]. Government Revenue constitutes a major component on a national budget [9]. Visser stated that municipal income has a great influence on a country's operation as it is the fundamental element for making financial and management policies. He further indicated that the key instrument ensuring funding is revenue and thus, "tax revenue collection should comply with best practices of equity, ability to pay, economic efficiency, convenience and certainty" [10]. Government revenue can, therefore, be inferred to as the income generated by the government from all sources within a period of time. Such financial resources enable the government to finance its spending. The Government Spending, on the other hand, depicts the nation's expenditures which are also reflected on the government budget when making fiscal policies [11].

It is worth mentioning at this juncture that individual positions represented as a source of government revenue can be reverted. In other words, a current source of income may be pronounced as obsolete, while a new source can be declared, customized, and added as a new source of revenue. A few instances of government revenue in Nigeria include the following: taxes on capital gain, companies' income, custom and excise duties, education., personal income, petroleum profit, stamp duties and value added taxes [12].

\section{Revenue Collection}

The government does not only collect revenues but may also offer incentives or 
subsidies. Such incentives can be in the form of a deduction or an exemption from tax or as discounts on credit interest rates. Any subsidy provided by the government is an implied negative revenue collection. Revenue collection is normally associates with the government organisations for billing and mobilising funds (such as taxes, miscellaneous fees, or fines), including debts owned by individual members of the public or by corporate bodies [13]. An effective government collection agency ensures a positive generation of municipal income and affluence on the management of the nation's fiscal policy and operations.

\section{Concept of Management}

Management is a process through which entities (such as organisations, Products, human resources, objects, etc.) are directed and controlled in order to attain a predefined set of targets. It oversees the activities of setting organizational strategies and coordination of employees or of volunteers' efforts in order to accomplish its objectives through the application of available resources, such as financial, natural, technological, and human resources [14]. Local governments were dependent primarily on the federal and state governments' statutory allocations of funds. Revenues that are internally generated, however, constitute only a small proportion of local government funds.

Such revenue includes registration of business premises, billboards, park fees, vehicle licence fees, tenement/property rates, marriage registration fees, etc. Fraud and corruption have made it difficult for local governments to deliver services to the people [15].

\section{Transparency, Resource Mobilisation and Conflict of Interest}

The local government administration is characterized by a lack of openness and transparency, the core ingredients for the democracies, for the market economies to function appropriately, and the primary key to build accountability and trust. Nigeria's local governments have generally found it extremely difficult to optimise revenue collection due to fraud, especially by revenue collectors, lack of manpower, and the crude methods of revenue collection [16]. Ajayi further highlighted that several sources that should be paying rates have actually been compromised, resulting to evading payments. As much as half of the revenue collected is thereby lost through "leakage," where the local government revenue collecting staff pockets the revenue rather than depositing it into a government account, a true scenario of conflicting interest.

This scenario is then reflected in the nonpublication of annual accounts, lack of proper auditing of local government accounts, inefficiency and fraud in revenue collection and revenue mobilisation, political interference, and lack of merit-based appointments and promotion of staff and conflicts of interest. The above foregoing background reveals that previous studies failed to give much emphasis on the impact of communication in the management of revenue collection. Previous research studies were also carried out in different organizations, and hence the findings cannot be used to establish revenue collection challenges at Onitsha Metropolitan Area. It is, therefore, against this background that this current study was undertaken; to fill the missing knowledge gap in the literature, by analyzing the impact of communication in the management of revenue collection in Onitsha Metropolitan Area, Anambra State.

\section{Materials and Methods}

This caption elaborates on the purpose of the study, the research questions, the Hypothesis that guided the study, the methods of data collection followed, the responds to the question, and how the problem was studied.

\section{Purpose of the Study}

The main purpose of this study is to survey the impact of communication in the 
management of revenue collection in the Onitsha Metropolitan Area, Anambra State. Specifically, it aims to:

1. Determine the impact of communication in the management of revenue collection in the Onitsha Metropolitan Area.

2. Ascertain strategies to enhance communication flow for effective management of revenue collection in the Onitsha Metropolitan Area.

\section{Research Questions}

The following research questions were formulated to guide the study:

1. To what extent do communication impact the management of revenue collection in the Onitsha Metropolitan Area?

2. What are the strategies to enhance communication flow for effective management of revenue collection in the Onitsha Metropolitan Area?

\section{Hypothesis}

The study is guided by the following hypothesis: There is no significant difference on the views of male and female revenue collectors regarding the impact of communication on the management of revenue collection in the Onitsha Metropolitan Area.

\section{Design of the Study}

For the purpose of this study, a descriptive research design was adopted. A survey was conducted on a few groups of people which was considered to be representative of the entire group [17]. The collected data was then analyzed, and the inference was made thereon. I decided to choose this design because this technique has been used successfully in similar studies.

\section{Area of the Study}

This research was carried out at the Onitsha Metropolitan Area located on the eastern bank of the Niger River in Anambra State, Nigeria. The city is famous for its river port which serves as an economic focal point for commence, industry and education. Furthermore, the city proudly provides the largest market platform in terms of its geographical size and volume of goods traded in African.

\section{Population, Sample, and Sampling Techniques}

The target population for this study was the revenue collectors in Onitsha Metropolitan Area, Anambra State. The sample of the study consists of thirty (30) revenue collectors selected through purposive sampling techniques, this comprised nineteen (19) males and eleven (11) females.

\section{Instrument for Data Collection}

The instrument used for data collection was a questionnaire titled: 'Communication and Revenue Management Scale (CRMS). The CRMS contained twenty items in cluster $\mathrm{A}$ on a four-point scale of VHE - Very High Extent (4), HE - High Extent (3), LE - Low Extent (2), VLE - Very Low Extent (1), and cluster B on a four-point scale of strongly agreed $(\mathrm{SA}=4)$, Agreed $(A=3)$, Disagreed $(D=2)$ and Strongly Disagreed $(S D=1)$. The overall theme of the items was based on the impact of communication in the management of revenue collection in Onitsha Metropolitan Area, Anambra State.

\section{Validation of the Instrument}

In order to determine the features and effective results of the research tool, the questionnaire was handed over to two persons with special skills in measurement and evaluation to examine and make necessary corrections and remarks. These experts were then given the purpose of the study and the research questions, alongside with the questionnaire items, to examine and make necessary corrections and remarks.

Their input was used by the researchers to modify the items of the questionnaire before the final draft. 


\section{Reliability of the Instrument}

The researchers used five (5) revenue collectors in Awka who were not participating in the main study. A copy of the questionnaire was then given to each of them to fill out, and these were immediately collected then after. The elements consisting of the questionnaire were remixed, reorganised, and then redistributed to the same teacher counsellors a fortnight later. The newly created questionnaires were collected after then and verified again using the test-retest reliability method. The mutual relationship between the scores of data collected were connected using Person-Product-Moment Correlation.

\section{Method of Data Collection}

The researcher administered the questionnaire personally. $\mathrm{He}$ administered 30 copies of the questionnaire to the selected respondents. They were collected from the respondents almost immediately after each completion; 30 copies of the questionnaire were retrieved, which yielded $100 \%$.

\section{Method of Data Analysis}

In analysing the data, the researchers used Mean \& Standard Deviation in answering the research questions. The acceptance point for the items stood at 2.5 Mean score equally (i.e., $\mathrm{SA}^{4}$, $\mathrm{SA}^{3}, \mathrm{SD}^{2}, \mathrm{D}^{1}$ ) totalling 10. Therefore, the Mean score equal $\frac{10}{4}=2.5$. Also, t-test statistics was also used to test for the hypothesis.

\section{Results}

Table 1 depicts the results of Research question 1: To what extent do communication impact the management of revenue collection in Onitsha Metropolitan Area?

Table 1. Arithmetic Mean and Standard Dispersion of Responses on the Extent to which Communication Impact the Management of Revenue Collection

\begin{tabular}{|l|l|l|l|l|l|}
\hline I/N & Item & \multicolumn{2}{l|}{ Male } & \multicolumn{2}{l|}{ Female } \\
\cline { 3 - 6 } & & $\overline{\boldsymbol{x}}$ & STD & $\overline{\boldsymbol{x}}$ & STD \\
\hline Item 1 & $\begin{array}{l}\text { Communication promotes motivation by informing and } \\
\text { clarifying the employees about the task to be done, the } \\
\text { manner they are performing the task, and how to improve } \\
\text { their performance. }\end{array}$ & 3.21 & 0.89 & 3.18 & 0.94 \\
\hline Item 2 & $\begin{array}{l}\text { Communication facilitates the co-ordination of the task, } \\
\text { which impacts the management of revenue collection. }\end{array}$ & 3.53 & 0.82 & 3.27 & 0.96 \\
\hline Item 3 & $\begin{array}{l}\text { Communication is a source of information to the } \\
\text { organizational members for the decision-making process as } \\
\text { it helps identifying and assessing alternative courses of } \\
\text { action. }\end{array}$ & 3.16 & 0.87 & 3.00 & 0.95 \\
\hline Item 4 & $\begin{array}{l}\text { Communication provides a complete understanding of the } \\
\text { employees' job as well as to communicate to them how their } \\
\text { job is related to other jobs in the organization. }\end{array}$ & 2.21 & 1.15 & 2.64 & 1.07 \\
\hline Item 5 & $\begin{array}{l}\text { Communication helps in socializing, leading to less } \\
\text { industrial unrest, which impacts the management of revenue } \\
\text { collection. }\end{array}$ & 2.63 & 1.22 & 2.73 & 1.14 \\
\hline Item 6 & $\begin{array}{l}\text { Communication helps in controlling organizational } \\
\text { member's behaviour, increase employee engagement, and } \\
\text { higher levels of creativity which impact the management of } \\
\text { revenue collection. }\end{array}$ & 3.16 & 1.04 & 2.73 & 1.14 \\
\hline $\begin{array}{l}\text { Item } 7 \\
\text { pommunication helps in solving various organizational }\end{array}$ & 2.21 & 1.06 & 2.64 & 1.07 \\
\hline
\end{tabular}




\begin{tabular}{|l|l|l|l|l|l|}
\hline & $\begin{array}{l}\text { absenteeism which impact the management of revenue } \\
\text { collection. }\end{array}$ & & & & \\
\hline Item 8 & $\begin{array}{l}\text { Communication facilitates information sharing, lessens the } \\
\text { chances for misunderstandings, and potentially reduces } \\
\text { grievances and lawsuits which impact the management of } \\
\text { revenue collection. }\end{array}$ & 3.47 & 0.75 & 2.91 & 0.79 \\
\hline Item 9 & $\begin{array}{l}\text { Communication builds employee morale, satisfaction, and } \\
\text { engagement which impact the management of revenue } \\
\text { collection. }\end{array}$ & 3.53 & 0.88 & 2.18 & 1.27 \\
\hline Item 10 & $\begin{array}{l}\text { Proper communication systems ensure reliable media flow } \\
\text { throughout the organization structure which impacts the } \\
\text { management of revenue collection. }\end{array}$ & 3.16 & 0.81 & 2.27 & 1.14 \\
\hline \begin{tabular}{l} 
Total \\
\hline
\end{tabular} & $\mathbf{3 0 . 2}$ & $\mathbf{9 . 4 9}$ & $\mathbf{2 7 . 5 5}$ & $\mathbf{1 0 . 4 7}$ \\
\hline
\end{tabular}

Table 2 shows results of Research Question 2: What are the strategies to enhance communication flow for effective management of revenue collection in the Onitsha Metropolitan Area?

Table 2. Arithmetic Mean and Standard Dispersion of Responses of Male and Female Revenue Collectors on Strategies to Enhance Communication Flow for Effective Management of Revenue Collection

\begin{tabular}{|c|c|c|c|c|c|}
\hline \multirow[t]{2}{*}{$\mathbf{I} / \mathbf{N}$} & \multirow[t]{2}{*}{ Item } & \multicolumn{2}{|l|}{ Male } & \multicolumn{2}{|c|}{ Female } \\
\hline & & $\overline{\boldsymbol{x}}$ & STD & $\overline{\boldsymbol{x}}$ & STD \\
\hline Item 11 & $\begin{array}{l}\text { Creating an open communication environment enhances } \\
\text { communication flow for effective revenue collection } \\
\text { management. }\end{array}$ & 3.05 & 0.83 & 3.09 & 1.00 \\
\hline Item 12 & $\begin{array}{l}\text { Engaging all employees by employing the inclusive } \\
\text { communication strategy enhances communication flow } \\
\text { for effective management of revenue collection. }\end{array}$ & 3.05 & 0.69 & 2.91 & 1.31 \\
\hline Item 13 & $\begin{array}{l}\text { Employing multiple channels to transfer messages } \\
\text { enhances communication flow to effectively manage } \\
\text { revenue collection. }\end{array}$ & 3.16 & 0.87 & 2.82 & 1.03 \\
\hline Item 14 & $\begin{array}{l}\text { Communicating objectives and goals with every } \\
\text { department enhance communication flow for effective } \\
\text { management of revenue collection. }\end{array}$ & 2.32 & 1.17 & 3.09 & 1.16 \\
\hline Item 15 & $\begin{array}{l}\text { Ensuring clarity in all communication enhances } \\
\text { communication flow for effective management of revenue } \\
\text { collection. }\end{array}$ & 2.68 & 1.22 & 2.82 & 1.11 \\
\hline Item 16 & $\begin{array}{l}\text { Prioritizing company culture and linking the } \\
\text { organizational communication plan to the business } \\
\text { strategy enhances communication flow for effective } \\
\text { management of revenue collection. }\end{array}$ & 3.11 & 1.07 & 2.82 & 1.11 \\
\hline Item 17 & $\begin{array}{l}\text { Using technology to facilitate communications enhances } \\
\text { communication flow for effective management of revenue } \\
\text { collection. }\end{array}$ & 2.53 & 1.23 & 2.73 & 1.05 \\
\hline Item 18 & $\begin{array}{l}\text { Providing opportunities for feedback enhances } \\
\text { communication flow for effective management of revenue } \\
\text { collection. }\end{array}$ & 3.42 & 0.82 & 3.27 & 0.96 \\
\hline
\end{tabular}




\begin{tabular}{|l|l|l|l|l|l|}
\hline Item 19 & $\begin{array}{l}\text { Celebrating achievements and milestones enhances } \\
\text { communication flow for effective management of revenue } \\
\text { collection. }\end{array}$ & 3.42 & 1.04 & 2.27 & 1.29 \\
\hline Item 20 & $\begin{array}{l}\text { Taking time to listen enhances communication flow for } \\
\text { effective management of revenue collection. }\end{array}$ & 2.79 & 1.00 & 2.18 & 1.11 \\
\hline & Total & $\mathbf{2 9 . 5 3}$ & $\mathbf{9 . 9 4}$ & $\mathbf{2 8}$ & $\mathbf{1 1 . 1 3}$ \\
\hline
\end{tabular}

Table 1 shows the extent to which communication impacts the management of revenue collection in the Onitsha Metropolitan Area. The results indicate that communication facilitates the co-ordination of the task, which impacts revenue collection management (Male $=3.53$, Female $=3.27$ ). It is obvious that communication promotes motivation by informing and clarifying the employees about the task to be done, the manner they are performing the task, and how to improve their performance $\quad($ Male=3.21, $\quad$ Female=3.18). Meanwhile, the female respondents disagreed that proper communication systems ensure reliable media flow throughout organization structure which impacts the management of revenue collection (2.27). In all, items $1-8$ having to mean score of 3.18, 3.27, 3.00, 2.64, $2.73,2.73,2.64$ and 2.91corresponding to standard deviation of $0.94,0.96,0.95,1.07$, $1.14,1.14,1.07$ and 0.79 were respectively accepted, while item 9 and 10 with mean score of 2.18 and 2.27 corresponding to standard deviation of 1.27 and 1.14 were respectively rejected by the female respondents. For the male respondents, items $1,2,3,5,6,8,9$, and 10 having a mean score of $3.21,3.53,3.16$, $2.63,3.16,3.47,3.53$, and 3.16 corresponding to standard deviation of $0.89,0.82,0.87,1.22$, $1.04,0.75,0.88$ and 0.81 were accepted respectively, while item 4 and 7 with a mean score of 2.21 and 2.21 corresponding to standard deviation of 1.15 and 1.06 were rejected respectively.

From table 2, the respondents agreed that providing opportunities for feedback enhances communication flow for effective management of revenue collection (Male $=3.42$, Female=3.27). However, female respondents agreed that communicating objectives and goals with every department enhances communication flow for effective management of revenue collection (3.09), whereas their male counterparts disagreed with a mean score of (2.32). Meanwhile, the female respondents disagreed that celebrating achievements and milestones enhances communication flow for effective management of revenue collection (2.27), whereas their male counterparts agreed with a mean score of (3.42). On the whole, items $11-18$ with mean score of $3.09,2.91$, $2.82, \quad 3.09, \quad 2.82, \quad 2.82, \quad 2.73$ and 3.27 corresponding to standard deviation of 1.00 , $1.31,1.03,1.16,1.11,1.11,1.05$ and 0.96 were accepted, respectively, and item 19 and 20 with a mean score of 2.27 and 2.18 corresponding to standard deviation of 1.29 and 1.11 was rejected respectively by the female respondents, while items 11, 12, 13, 15, 16, 17, 18, 19 and 20 with a mean score of $3.05,3.05,3.16,2.68$, $3.11,2.53,3.42,3.42$ and 2.79 corresponding to standard deviation of $0.83,0.69,0.87,1.22$, $1.07,1.23,0.82,1.04$ and 1.00 , and item 14 with a mean score of 2.32 corresponding to standard deviation of 1.17 were rejected respectively by the male respondents.

Hypothesis 1: There is no significant difference on the views of male and female revenue collectors regarding the impact of communication on the management of revenue collection in the Onitsha Metropolitan Area. 
Table 3. Summary of t-test on Male and Female Revenue Collectors regarding the Impact of Communication on the Management of Revenue Collection

\begin{tabular}{|l|l|l|l|l|l|l|l|}
\hline Source & N & Mean & Std. dev & t-Cal & t-crit & $\mathbf{d}_{f}$ & P. Value \\
\hline Male & 19 & 30.27 & 9.49 & 0.709 & 2.0484 & 28.00 & 0.4842 \\
\cline { 1 - 4 } Female & 11 & 27.55 & 10.47 & & & & \\
\hline
\end{tabular}

$\operatorname{Sig}<0.05$

Table 3 shows that at 0.05 level of significance and $28^{\circ}$ of freedom, the calculated $\mathrm{t}=0.709$ is less than the critical $\mathrm{t}=2.0484$. Therefore, the null hypothesis is accepted, the researcher concludes that there is no significant difference on the views of male and female revenue collectors regarding the impact of communication on the management of revenue collection in the Onitsha Metropolitan Area. Research question 1 sought to find out the extent of communication impact on the management of revenue collection in the Onitsha Metropolitan Area. The study found that communication facilitates coordination of the task, which impacts revenue collection management. This view has previously been promulgated by Sausi, Kitali \& Mtebe, who observed revenue as all tools of income to the government to which the legislature has the power of appropriation such as taxes, rates, fees, fines, duties, penalties, rents, dues, proceeds, and other receipts of government. $\mathrm{He}$ further classified government revenue into two kinds: recurrent revenue and capital revenue [1]. Zhou \& Madhikeni maintains that communication promotes motivation by informing and clarifying the employees about the task to be done, the manner they are performing the task, and how to improve their performance [18]. He also implies that proper communication systems ensure reliable media flow throughout the organization structure, which impacts revenue collection management.

Research question 2 dealt with the strategies to enhance communication flow for effective management of revenue collection in the Onitsha Metropolitan Area. Based on the analysis, the respondents agreed that providing opportunities for feedback enhances communication flow for effective management of revenue collection. Fang, Cassim, Hsu, and Chen noted that the use of peer feedback enhanced oral communication [19].

However, celebrating achievements and milestones enhances communication flow for effective management of revenue collection. In most cases, employing multiple channels to transfer messages enhances communication flow for effective management of revenue collection. Finally, Sutiyatno opined that prioritizing company culture and linking the organizational communication plan to the business strategy enhances communication flow for effective management of revenue collection [20]. Culture creates and influences the environmental framework in which an organization operates. It also determines the nature of the strategic plans that inevitably propel the organization towards its vision of efficient revenue mobilization and administration. In most cases, the corporate culture largely dictates the traditions, policies, economic trends, business processes, international trade, company size, etc. and enable the organization to live out its mission on a daily basis.

\section{Discussion}

Research question 1 sought to find out to what extent do communication impacts the management of revenue collection in the Onitsha Metropolitan Area. The study found that communication facilitates the co-ordination of the task, which impacts the management of revenue collection. This view has previously 
been promulgated by Sausi, Kitali \& Mtebe [1], who observed revenue as all income instruments of a government from taxes, excise duties, penalties, or other sources which the legislature deemed to the payment of public expenses. Broadly speaking, the government revenue may further be categorized into recurrent revenue and capital revenue. Zhou \& Madhikeni maintains that communication promotes motivation by informing and clarifying the employees about the task to be done, the manner they are performing the task, and how to improve their performance [17]. He also implies that proper communication systems ensure reliable media flow throughout organization structure which impacts the management of revenue collection.

Research question 2 dealt with the strategies to enhance communication flow for effective management of revenue collection in the Onitsha Metropolitan Area. Based on the analysis, the respondents agreed that providing opportunities for feedback enhances communication flow for effective management of revenue collection. Fang, Cassim, Hsu, and Chen noted that the use of peer feedback enhanced oral communication [18]. However, celebrating achievements and milestones enhances communication flow for effective management of revenue collection. In most cases, employing multiple channels to transfer messages enhances communication flow for effective management of revenue collection.

Finally, Sutiyatno opined that prioritizing company culture and linking the organizational communication plan to the business strategy enhances communication flow for effective management of revenue collection [19]. Culture creates and influences the environmental framework in which an organisation operates. It also determines the nature of the strategic plans that inevitably propel the organization towards its vision of efficient revenue mobilization and administration. In most cases, the corporate culture largely dictates the traditions, policies, economic trends, business processes, international trade, company size, etc., and enables the organization to live out its mission daily.

\section{Conclusion}

The study has been able to examine the impact of communication in the management of revenue collection in the Onitsha Metropolitan Area, Anambra State. The results of this study have shown that communication facilitates coordination of the task, which impacts the management of revenue collection; communication builds employee morale, satisfaction, and engagement, impacting the management of revenue collection. The findings also revealed that providing opportunities for feedback enhances communication flow for effective management of revenue collection. The study also made it clear that celebrating achievements and milestones enhances communication flow for effective management of revenue collection.

\section{Educational Implications}

The insight acquired from this study has immense significance for education. The study findings will create an open communication environment that enhances communication flow for effective management of revenue collection. The study, therefore, may be helpful by creating an open communication environment that enhances effective communication flow. Government leaders can leverage the findings of this study to inspire others and maintain a climate to enhance communication flow for effective management of revenue collection in the Onitsha Metropolitan Area.

\section{Recommendations}

Based on the findings and the conclusion arising from the study, the following recommendations are hereby made:

1. The local government chairman should ensure that machinery be in place to generate more revenue internally to enable them to do more development projects. 
2. Training and re-training programs for the revenue officials should be organized to enable them meets the challenge of the new millennium.

3. Competent hands should be employed in the revenue section.

4. Enlightenment campaigns on the revenue to be paid by an individual should be carried out.

5. Control measures should be put in place to check possible frauds and embezzlement.

6. Automating and digitalizing the process of revenue collections will enhance efficient and effective service provision coupled with high customer satisfaction.

\section{References}

[1] Sausi, J. M., Kitali, E. J., \& Mtebe, J. S. (2021). Evaluation of local government revenue collection information system success in Tanzania. Digital Policy, Regulation, and Governance.

[2] Obiaso, C. B., Odumu, W. R., \& Iyenagbe, F. O. (2021). Impact of high taxes on the performance of small and medium scale businesses in anambra state. International Journal of Management and Entrepreneurship, 3(1), 276-306.

[3] Yuliaty, F. (2021). The Importance of Organizational Communication in Improving Employee Performance: A Case Study of the Regional Revenue Management Agency of the City of Bandung. International Journal of Science and Society, 3(1), 361-370.

[4] Balconi, M., \& Fronda, G. (2020). The use of hyperscanning to investigate the role of social, affective, and informative gestures in non-verbal communication. Electrophysiological (EEG) and inter-brain connectivity evidence. Brain sciences, 10(1), 29.

[5] Sutiyatno, S. (2018). The effect of teacher's verbal communication and non-verbal communication on students' English achievement. Journal of Language Teaching and Research, 9(2), 430-437.

\section{Acknowledgements}

I wish to thank God Almighty for making it possible for me to complete this journal. I offer my appreciation for the learning opportunities provided by my special mentor Ms. Anitha. A, \& Ms. Mayuri Meha GV.

To the respondents from the Onitsha Metropolitan Area of Anambra State of Nigeria, who participated in my research, I am thankful. To my employer, German Academic Exchange Service $(D A A D e V)$. I am grateful.

Lastly, I cannot express enough thanks to my family for their encouragement: my wife Lucy Wairimu, my son Joseph Jr., and my daughter Seraphin.

Thank you. Joseph Brown.

[6] Adu-Gyamfi, E. (2014). Effective revenue mobilisation by districts assemblies: A case study of Upper Denkyira East Municipal Assembly of Ghana. Public Policy and Administration Review, 2(1), 97-122.

[7]Fayemi, O. A. (1991). Principle of Local Government Accounting Chapter Ten Publication Ltd, Yaba-Lagos.

[8] Hepworth, N.P. (1976). the finance of local government, Gorge Allen, London.

[9] Nwosu, D. C., \& Okafor, H. O. (2014). Government revenue and expenditure in Nigeria: A disaggregated analysis. Asian Economic and Financial Review, 4(7), 877.

[10] Visser, C, B. and Erasmus, P, W. (2005). The Management of Public Finance: A Practical Guide Oxford University Press: Oxford.

[11] Nwosu, D. C., \& Okafor, H. O. (2014). Government revenue and expenditure in Nigeria: A disaggregated analysis. Asian Economic and Financial Review, 4(7), 877.

[12] Odimegwu, C. N., \& Igwe, C. (2020). Adequate tax policy and implementation: a panacea to the success of a property tax system. a case of the failed anambra state property and land use charge (APLUC). Tropical Built Environment Journal, $7(1)$. 
[13] Odoyo, C. O., Moses, O., John, M. O., Aila, F. O., Ojera, P. B., \& Siringi, E. M. (2013). Effect of information systems on revenue collection by local authorities in Homa Bay County, Kenya. Universal Journal of Accounting and Finance, 1(1), 29-33.

[14] Ngotho, J., \& Kerongo, F. (2014). Determinants of revenue collection in developing countries: Kenya's tax collection perspective. Journal of management and business administration, 1(1), 1-0. [15]Koskei, A., Cheruiyot, P., \& Naibei, I. (2019). Revenue Collection Efficiency in the County Government of Kericho, Kenya. East African Journal of Business and Economics, 1(1), 9-21.

[16] Ajayi, M. O., Ejindu, C, E., Okoyjie, C. C., Ikenna, U. C., (2007). Structure Plan for Onitsha and Satellite Towns. State Economic Empowerment and Development Strategies (SEEDS), Anambra State Government Printer Awka., Second Edition, 32-33.

[17]Nworgu, B.G (2015). Educational research. Basic issues \& methodology (3rd ed.). Nsukka: University Trust Publishers.

[18]Zhou, G., \& Madhikeni, A. (2013), Systems, Processes and Challenges of Public Revenue Collection in Zimbabwe. American International Journal of Contemporary.

[19]Fang, W. C., Cassim, F. A., Hsu, C. N., \& Chen, N. S. (2018). Effects of reciprocal peer feedback on EFL learners' communication strategy use and oral communication performance. Smart Learning Environments, 5(1), 1-16.

[20] Sutiyatno, S. (2018). The effect of teacher's verbal communication and non-verbal communication on students' English achievement. Journal of Language Teaching and Research, 9(2), 430-437.

[21] Ezeabasili, A. C. C., Anike, O. L., \& Okonkwo, A. U. (2014). Management of urban water for domestic and industrial uses and sustainability in Anambra State, Nigeria. International Journal of Water Resources and Environmental Engineering, 6(8), 212-219.

[22] Anambra State Local Government System, (2007). Onitsha South Local Government Area: Local Economic Empowerment and Development Strategy (LEEDS), $1^{\text {st Edition. }}$

[23]Anambra State Local Government System, (2007a). Onitsha North Local Government Area: Local Economic Empowerment and Development Strategy (LEEDS). 


\title{
Opportunities and Constraints within the Agribusiness Industry in the Emerging Market of Ghana
}

\author{
Richard Asante $^{1 *}$, Rheeta Marjery ${ }^{2}$, Frank Boateng ${ }^{3}$ \\ ${ }^{1}$ Business Development Manager, AECI process and water, West Africa \\ ${ }^{2}$ Principal, Sree Pashmi Institute of Management, India \\ ${ }^{3} \mathrm{Ag}$. Head, management studies department, UMAT, Ghana
}

\begin{abstract}
The purpose of the study is to conduct an empirical investigation into the important role of technology in a value-driven business process design for an emerging market. Emerging markets are characterized by low GDP because of low economic activities. However, it is full of business opportunities within its environments for prospective businesses or existing small business which wants to scale up or globalize. Moreover, many business constraints exist some are poor technological infrastructure, institutional voids, bribery and corruption, bureaucracy, and poorly trained human capital. There was a critical examination of extant studies by several scholars and researchers related to the objective of the study. The main focus of the review is to establish strong conceptual, theoretical, and empirical support for this study. These included segments that dealt with the conceptual framework review of competitive advantage and theoretical reviews of the Network Theory. Structured as the third segment is the empirical review. This entails an in-depth review of extant studies related to the three-pronged objectives, with the aim of either rejecting or accepting the underlying framework in such studies. Thematic analysis was employed for analysing the primary data collected via focus group discussion plus in-depth interviews. An in-depth examination of the responses of participants revealed that though the majority (19) of the participants agreed that emerging market has several potential and benefits, yet they indicated the existence of certain constraints mitigating increased investment in agribusiness in Ghana, as demonstrated in the excerpt.
\end{abstract}

Keywords: Constrains, Emerging market, Opportunities.

\section{Introduction}

Several studies provide ample information regarding the several opportunities associated with an emerging market and strongly believe that such opportunities are minimally tapped. For example, the interest in emerging markets offers comes is in part because they offer phenomenon fast growth and entail the potential for further growth. Growth rates have generally slowed for instance, after Goldman Sachs started "dreaming with BRICs," referring to the emerging economies of Brazil, Russia, India, and China [1]. But as developed economies offer small or no market growth during these austerity moments, emerging markets look more promising for businesses to sustain and grow their revenue and profitability. Moreover, a larger percentage of emerging economies is marked with a faster rate of economic growth in GDP than in developed countries. It was discovered that cutting-edge technology could be very useful within an emerging economy due to the developing nature of the economy and less saturation of technological innovation in comparison to a developed economy [2]. A study also indicated

Received: 25.11.2021

Accepted: 17.12.2021

Published on: 28.02.2022

*Corresponding Author: rasanten348@gmail.com 
that emerging markets are not as stringent and efficient as well as with less sophistication in comparison to markets in developed economies where bureaucracies and high standard of security and tax deduction together with security regulation could drain out initial capital for a startup [3].

\section{Conceptual Framework}

\section{Concept of Competitive Advantage}

The concept of competitive advantage has been described by [4] as terminology that "might garner the prize for the most overworked and least understood catch-phrase" (p. 32). [4] further stated that extension of the terminology into "sustainable competitive advantage", is at present, an elaboration of ambiguity" (p. 48). Deepening the controversy surrounding competitive advantage, [5] asserted that over time business strategy has gradually substituted competitive advantage, and scholars are puzzled regarding what constitutes a competitive advantage.

An important component of the successful establishment of a value chain business in an emerging market is a competitive advantage. There is fierce competition among businesses due to the revolutionary trend of technology and globalization; hence firms must make a concerted effort at building and maintaining requisite skills and competencies and exhibit dynamism in adapting to the new environment [6], as well as meeting the fleeting demands of customers, values, and processes [7]. It is observed in [8] that challenges associated with competition and customer needs and a tumultuous business environment can be successfully met with the application of the conceptual framework of competitive advantage. However, asserted that due to a plethora of confusing information, a strategic manager disentangles the knotty gaps, the dichotomy of opinion, and ambiguity surrounding competitive edge to orchestrate his exploiting all avenues to gain a competitive edge in an emerging market [8]. This notion impels the review of the concept of a competitive edge.

Competitive edge has been variously defined, described, and explained following the groundbreaking coinage of the expression by [9]. For example, [10] sees the competitive advantage as a set of executable actions or qualities by a business organization to outdo its competitors. This can be described from the perspective of when the business operation of an organization yields more profit than those of its competitors or in a situation where the organization tower over competitors in several other significant aspects of business operations in a given market. In his notable work, [11] provides a succinct description of what influences competitive advantage. The description provides insight and captures the complexity regarding competitive advantage as well as the overall objective of the study. [11] conceives competitive advantage and the resultant improved organizational performance as representative of the adaptive ability of an organization to its environment, underscoring the point that a business organization that succeeds in adapting to the environment it operates should be capable of matching its strength with the numerous opportunities within its environment including emerging market. Hence, [11] categorized factors influencing adaptation into four-pronged issues:

1. "Whether the firm's strategy is congruent with its industry structure and competitive context".

2. "Whether its organizational structure fits its environment and strategy".

3. "Whether its management systems fit its strategy".

4. "Whether its management style is tailored to the strategic context including the development of right competencies".

There are other schools of thought regarding how competitive advantage should be analyzed. Two have gained prominence in recent times, and these are: 1) Resource-Based View and 2) Position-based view. Promoting a resource- 
based view, some scholars such as [13-15] felt competitive advantage can be analyzed using a resource-based view. From their standpoint, they believe that when resources in a given market are scarce, appropriable, specialized, rare, valuable, cannot be duplicated strategically, and difficult to imitate, it will gain a competitive advantage. Lending credence to the resource-based view of competitive advantage, by competitive advantage, [16] also refers to sustainable competitive advantage, which is a situation where a firm is capable of creating true value that is difficult for competitors to copy. A firm in this situation is able to earn economic rents. In effect, if a single unit of the product costs five cedis, the cost of production should be lower than five and perhaps four cedis for profitability purposes. The perceived value of the product among customers should be higher than what they pay for the product. In recent times, scholars and managers have expanded the horizon and conducted studies to critically investigate strategic mechanisms related to the attainment of competitive advantage with responsible CSR to ensure sustainability.

A Study [17] introduced the concept of a resource-based view of competitive advantage to address the shortcomings of environmental models to link up heterogeneous resources, their mobility, and its strategic or competitive advantage. This is represented in figure 3 below.

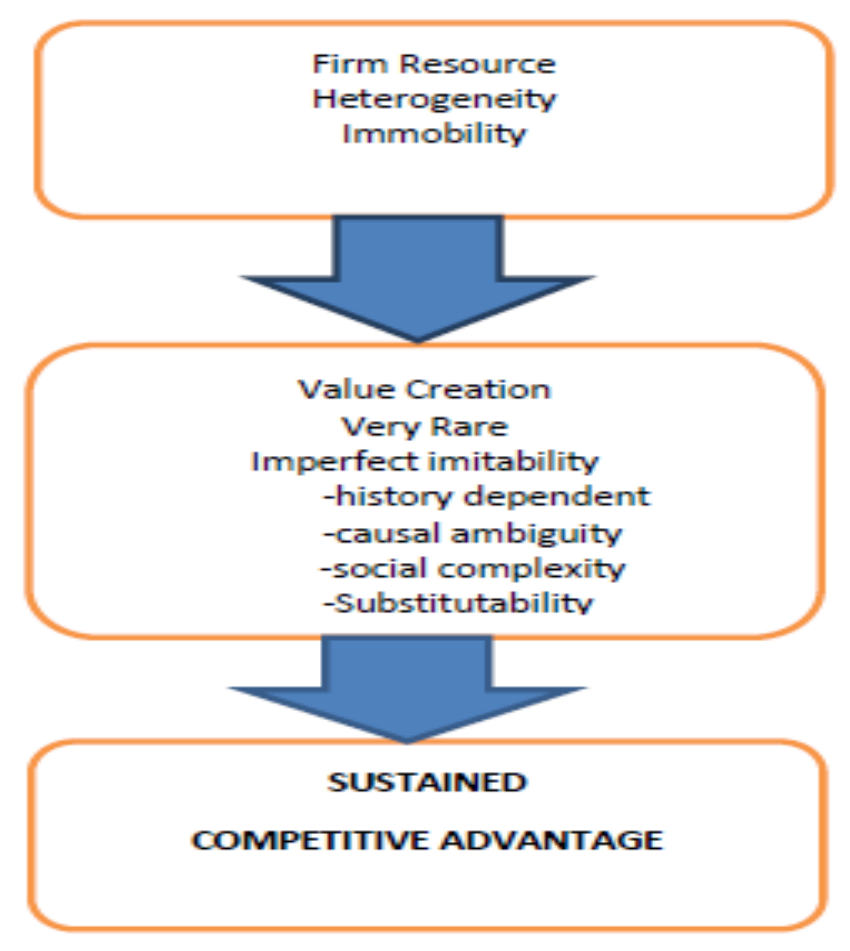

Figure 1. Resource-Based View of Competitive Advantage

Source: Adapted from Barney (1991)

On the other hand, the position view of analyzing competitive advantage places emphasis on the exploitation of the unique position of the business, the environment, and raw materials with a view to minimizing cost, maximizing profit, and continually sustain competitive advantage and business ideals.

\section{Theoretical Framework}

\section{Network Theory}

As an offshoot of U-Model, Network Theory considers a firm's entry into emerging markets from the perspective of interdependent the proponent of network theory argues that due to the complex interactions within an emerging 
market, it is difficult for firms to follow the sequential or incremental steps espoused by the U-model theory. Within a Business Network Context In business-to-business settings, dyadic relationships between firms are of paramount interest [18]. Instead, prospective firms rely on resources of accruing from partners within the sector and market. [19] refer to this network as an ecosystem. The diagram in Figure 1 vividly portrays the opportunities and constraints that a prospective firm may experience when entering into an emerging market comprising several upstream and downstream partners.

External complement challenges

\begin{tabular}{|c|c|c|}
\hline & Low & High \\
\hline 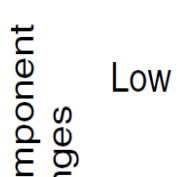 & $\begin{array}{l}\text { Internal innovation } \\
\text { challenges }\end{array}$ & $\begin{array}{l}\text { Internal challenges + } \\
\text { external constraint } \\
\text { on consumption }\end{array}$ \\
\hline$\frac{\bar{\pi}}{\overline{\frac{\pi}{\sigma}}} \overline{\frac{\pi}{0}}$ & $\begin{array}{l}\text { Internal challenges + } \\
\text { external constraint } \\
\text { on production }\end{array}$ & $\begin{array}{c}\text { Internal challenges + } \\
\text { external constraints } \\
\text { on production and } \\
\text { consumption }\end{array}$ \\
\hline
\end{tabular}

Figure 2. Impact of Ecosystem Challenges on a Prospective Investor

Source: Adner and Kapoor (2009)

A closer study of figure 1 shows that most of the literature on network theory often focuses on the first quadrant by the left with low external challenges. This implies that as soon as the firm overcomes her internal challenges, it can successfully enter into the merging market. However, the remaining three quadrants show reveals high external component challenges as well as internal challenges to be overcome before the firm can enter into the emerging market.

\section{The Implication for the Proposed Study}

The theory underpins the focus of the study because it underscores the gap in the literature concerning the constraints a prospective firm could encounter before successful integration into the market. Initially, it was conceived that as soon as a firm overcomes the internal challenges of integrating technology as a source of value creation, it would have attained a competitive advantage.
However, in the works of many researchers, including [19] studies, external challenges arising from interdependent partners concerning the use of appropriate technology could seriously impact any success a firm could attain even if it has overcome internal challenges within its establishment.

For example, a plastic corporation only needs to device appropriate technology to produce its plastic. Suppliers, customers, and others need not worry about complementing the technology employed in the production of plastics. However, a firm such as a hotel would need its upstream (suppliers) and downstream (customers) partners to cooperate with the technologies adopted for operations otherwise, the firm may not be viable.

However, the nature of challenges to be confronted by individual firms entering into emerging markets differs. A firm to use cuttingedge technology for value creation and maintenance of a competitive edge must carefully consider the best form of technology 
during process design. Hence, there is a need to fill the lacuna in understanding regarding a firm interested in agribusiness in an emerging market economy.

\section{Literature Review}

Emerging markets are very competitive and are constantly growing with new trends and technology alongside several constraints. This underscores the fact that an agribusiness investor should calculate the cost by making a novel decision on ensuring competitive advantage, increased productivity, and continuity. All of which can be done by the adoption of appropriate technology [20]. Every strategy should be directed towards overcoming entry or emerging constraints and leveraging on existing advantages.

This paper examines an issue which in within the jurisdiction of Ghana, an emerging economy in sub-Sahara Africa, from independence to 2020[20]. A historical review of post-independence government policies shows three distinct phases of technological transformation. These include.

1. Adopting "science for development" strategy and convergence of science and industrial policy between 1957 to 1966 .

2. The divergence of science policy and industrial policy between 1967 to the 1990s after the overthrow of Dr Nkrumah's government.

3. The emergence of the "new dawn" from the 2000s which ushered in a brand-new policy framework for national science and technology policy formulated towards economic development.[20].

However, the review argues that there are several constraints leveled against the instrumentality of technology in the process of designing value-driven business within an emerging market such as Ghana in sub-Saharan Africa [21]. Despite these constraints, it remains a potent variable and an inextricable element for successful business ventures in the emerging market. Conceptual and theoretical frameworks were synthesized to determine whether several theories underpinning the influence of technological innovation need modification given the ever-changing terrain of technological breakthroughs.

In fulfilling the main objective of the study, the researcher seeks to retrieve firsthand information regarding the socio-economic and day-to-day realities in African society. Hence, the review contended that most of the studies on the facilitation of value-driven business within the environment of the emerging market are secondary data. It has limited studies employing primary data or empirical investigation as an approach to research.

The findings of several studies [22] revealed that there are certain limiting factors associated with emerging markets. These include digital infrastructural constraints, shifting sand of tax law on digital technology, poor digital security, and localization. This study argues that rigorous interrogation of extant studies along with empirical findings will help in distilling relevant information. This information is useful in developing the innovative approach which, if used by investors, can override these hurdles and create a value chain and thriving enterprise in Agribusiness.

\section{Empirical Review}

This section of the study critically examined extant literature about the objectives of the study. Studies were examined chronologically to isolate gaps in the literature and elicit strong empirical support for the focus of the present study. The review in this section examined relevant studies in connection with several market opportunities within emerging markets ready for exploitation by an investor or business organization alongside constraints that may limit such exploitation.

The empirical review also touched on the inestimable benefit of technology-savvy businesses over the traditional businesses in terms of a competitive edge as well as profit margin. Another aspect of technology-savvy 
businesses was also examined, especially about Corporate Social Responsibility, which is considered an important factor in competitive advantage within an emerging market [23].

\section{Market Opportunities and Constraints in Emerging Market}

Several studies provide ample information regarding the several opportunities associated with an emerging market and strongly believe that such opportunities are minimally tapped. For example, due to the availability of financial infrastructures such as stock exchange platforms, banks, and unified currency, organizational leaders usually exploit these avenues to tap limitless opportunity for new business organization because it often yields high returns due to reduced tax deductions in comparison to developed economies. Moreover, a larger percentage of emerging economies is marked with a faster rate of economic growth in GDP than in developed countries. However, financial globalisation has been associated with divergent current account patterns in emerging markets. [24] Found out that better developed and more integrated financial markets increase emerging markets' ability to borrow abroad.

[24] discovered that cutting-edge technology could be very useful within an emerging economy due to the developing nature of the economy and less saturation of technological innovation in comparison to a developed economy. [3] also indicated that emerging markets are not as stringent and efficient as well as with less sophistication in comparison to markets in developed economies where bureaucracies and high standard of security and tax deduction together with security regulation could drain out initial capital for a startup.

Over the last two decades, emerging market economies (EMEs) have become a dominant presence in the world economy. They now account for a substantial share of world output and, with their rapid growth rates, have become a major driver of global growth during the past decade. Trade and financial linkages between advanced economies and EMEs have also become much stronger, speeding up the process of global integration [25].

Developing nations have poor distribution systems. In large cities, distribution is often through small, hole-in-the-wall shops such as the paanwalla shops in India, the tiendas de la esquinas in Mexico, and sari-sari stores in the Philippines [22].

A market of 600 million is locked in India's villages, 42 percent of which have populations of less than 500, with weak connections to the outside world. The lack of media, roadways, and electricity creates seemingly impenetrable barriers. Some villages don't have retail outlets at all, and some distribution opportunities, such as market days or carnivals, are temporary in nature [22].

New incumbents must adopt innovative networking, diversification, employ technological innovation, internationalize, and develop rare requisite skill scarce in an emerging market.

In an extensive study, [26] explored several opportunities and constraints associated with the emerging market. The study was conducted using a qualitative research paradigm and multiple case research design. An in-depth interview was used as an instrument for the study. The interview was conducted with only three business leaders and members of the management staff in three organizations in Nigeria. Such constraints involve weak institutions, unbalanced emphasis on informal institutions over formal ones, pressure arising from local government intervention in business activities, institutional transition, and changes.

A [26] study revealed that the adoption of a multiple case study research design was very appropriate for the study since the philosophy of the study was interpretative and deductive. Though it mentioned the constraints associated with an emerging market, it also discussed certain business opportunities associated with the emerging market. His study revealed that an investor bent on tapping into an emerging 
market can overcome the constraint endemic in the emerging market by having a resourcebased view of competitive edge. [26] argued that instead of modifying the already existing business model, Multinational corporations or new investors should critically examine the local market, design, and produce local products commensurate to the emerging market environment with a certain group of consumers or customers in mind.

The reviewed studies revealed that while the emerging market is riddled with a lot of weaknesses that can complicate business operation, it is can be transformed into an enabling environment for a thriving business dependent on the innate resourcefulness of prospective investors. It is also worthwhile for a prospective business that emerging market is loaded with several opportunities ranging from cost minimization (cheap labor and accessibility to raw materials at a reduced price, access to a larger market in comparison to domestic markets, to diversification, increased productivity (large scale) and profit interested in the emerging market must have the tenacity and decisiveness in making proactive move regarding product design and customer relations so that each product is representative of the commitment of the new incumbent.

\section{Methodology}

An inestimable aspect of research project is the systematic approach to the collection of relevant information, with a view to filling the lacuna in literature as well as adequately addressing research problems [27] In a bid to garner rich data culminating in well-validated and reliable findings, the method adopted, should be unbiased and rigorous [28].

A critical examination of the theories undergirding the present study, comprising Network Theory, necessitates the adoption of interpretivism as the research philosophy. The theoretical perspective of interpretivism revolves around making sense of the subjective intention and varied meanings of subjects within a context or universe of a study, without the imposition of a priori analytic groupings $[29,30]$.

Interpretivism entails concerted effort by the researcher at understanding the world from the viewpoint and first-hand information retrieved from the study's participants.

Findings of several studies [29, 31, 32], reveals that there are three-pronged approaches to the research project, namely: 1) quantitative paradigm, 2) qualitative paradigm, and 3) mixed-methods combining qualitative and quantitative research paradigms. After a careful examination of the three forms of research paradigms, the qualitative research paradigm is adopted for this study in view of the research philosophy guiding the study. [33] Indicated that qualitative paradigm is useful in conducting an in-depth investigation concerning the subject matter of a study and enhance researchers' ability to employ case studies or multiple case studies with a view to furnishing a narrative or descriptive account of practice or design.

Qualitative research design is very suitable for the study because it facilitates efforts at gaining a deeper understanding of the relevant facets for the collection of well-validated information based on first-hand experience of participants' void of manipulation by the researcher. [34] indicated that like quantitative research design, qualitative studies can also be generalized into bigger population.

Relevant data was elicited from 22 participants. In-depth interview was conducted with 10 participants comprising both management and non-management staff. For the purpose of moderating Focus Group Discussion, 12 participants were divided into three groups comprising four participants with a view to distilling relevant information related to the focus of the study.

Process managers and other professionals such as those in the R\&D and Marketing Department were interviewed. I consulted relevant sources, including peer-reviewed 
sources with the aim of bridging the gaps identified at the outset of the study as well as retrieve valuable information to aid resolution of research problems. Due to the successes, they have achieved in their respective businesses, and they possess a wealth of experience on transcending limiting factors such as unpredictable market forces, weak institutions, and difficulty associated with the selection of the most appropriate technology. Participants comprised 12 men and 10 women.

The majority (14) of the participants have over 8 years of working experience, 4 had over 12 years of working experience, while the remaining 4 had less than 8 years of working experience. This clearly demonstrated that these group of participants can provide rich data as far as the focus of this study is concerned.

\section{Research Instruments/Measurements}

The proposed study will employ two major instruments for data collection. Structure interview guide and focus group discussions will be relevant in collecting pertinent information from participants and respective cases. Suggesting appropriate means of employing a structured interview guide, [35] indicated that an interview guide should be designed so as to elicit the best possible information from the participants to the end of enriching the findings of the study. This means much attention will be given to the content of the interview guide.

The guide will be structured so as to touch on relevant issues that would fast track resolution of the research question. The guide will elicit important information regarding the potentials and constraints alongside the nature of competition associated with emerging markets. It will also entail open-ended questions probing how firms, especially locally owned ones, can exploit the numerous opportunities in an emerging market using appropriate technology. The guide will also touch on how these firms' overcome constraints that could have mitigated entry into emerging markets or continuity of value-creation and competitive edge.

[36] posited that the Focus Group interview (FGI) is a highly result-oriented and credible instrument for data collection in a qualitative research approach. [36] defined Focus Group Interview as a technique where participants are drawn from various backgrounds within the sphere of the phenomenon under study to discuss and relieve complex personal experiences, perceptions, beliefs, attitudes, and perceptions via a moderated or coordinated interaction. [37] succinctly stated that it creates an avenue where the researcher co-creates meaning with participants on the given subject, phenomenon, or topic under consideration. Conducting the focus-group discussion was extremely cost-effective and was advantageous, as it allowed several people to participate at once in a short amount of time. Focus-group discussions allow the researcher to observe the interaction and non-verbal cues within the group. The participants are also able to support each other when points are discussed, which has the potential to evoke deeper conversation and views on the subject matter [37].

As a result, stakeholders in the agribusiness would be selected for the study and interviewed as well as participate in focus group discussion alongside other staff within the firm. This will ensure the co-creation of meanings regarding the focus of the study.

\section{Techniques for Data analysis}

Thematic analysis will be employed for analyzing primary data collected via focus group discussion and in-depth interviews. According to [38], thematic analysis involves immersion in textual data with the sole aim of deciphering and identifying emerging trends, patterns, and themes for analysis.

In order to gather credible and reliable data, all interview and focus group discussions were recorded with a digital recorder based on the consent of participants. Recorded interviews and discussions were played afterward and 
manually transcribed for identification of trends, patterns and themes relevant to the resolution of research problems.

The themes generated will be used as a major reference point for the analysis. In certain cases, verbatim quotations from transcribed data will be reproduced to enable readers to feel the pulse of the study and deepen knowledge on strategic management associated with appropriate technology, value-creation, and emerging market $[2,39,40]$.

There are various approaches to conducting thematic analysis, but the most common form followed is a six-step process:

1. Familiarization.

2. Coding.

3. Generating themes.

4. Reviewing themes.

5. Defining and naming themes.

6. Writing up.

\section{Results}

The primary focus of this chapter is to unravel relevant insight, trends, patterns, and themes from the elicited data for the study. In effect, this section deals with findings or outcomes of the study within the context of the transcribed data retrieved from the field. The overarching objective of the study is to conduct an empirical investigation into the important role of technology in a value-driven business process design for an emerging market.

\section{Extracts and Analysis}

\section{Research Question \#1}

\section{What are the Major Market Opportunities and Constraints the Emerging Markets offer Business Organization Desiring to enter Emerging Markets?}

The primary focus of this question is to elicit relevant information regarding inherent features of emerging markets as well as ascertain specific market opportunities open to the selected agribusinesses within Ghana as an emerging market. Resolution of the question also necessitates uncovering several mitigating factors (if any) the selected cases are confronting in horning their competitive edge within Ghana.

In their response to the question on what constitutes an emerging market, the majority, they viewed it from the perspective of size, policies, and regulatory measures peculiar to an emerging market that makes it vastly different from other types of market. The excerpt below is representative of the responses of participants.

Emerging market is not limited to only one geographical location or region of the world, and it could be found in any part of the world and usually characterized by lower-thanaverage per capita income as well as distinctive rapid rate of economic growth. Another word for emerging market, from my perspective, is any developing economy which include China, India, and Ghana.

unlike developed economy, emerging economy offers reduced tax rates, cheap labour, and accessibility to raw material, for example, all our raw materials can be found in Ghana, no need for importation. This helps in minimizing cost of production which in turn, reduced prices of products and increase patronage and profit.

A closer study of the excerpt above revealed that an emerging market is usually a developing economy with low GDP per capita and highlevel potential for growth. The low GDP per capita underscores the reason why such an economy is undergoing rapid growth in comparison to the developed economy, which is less attractive to the investor. Intense interest at improving their economy, the government of emerging markets formulate several policies directed towards attracting investors and multinational organizations in dire need of expanding the frontiers of their business activities.

Another noteworthy feature of an emerging market, as identified in the excerpt, is the dependence on agricultural products, which coincides with the drive for agribusiness in 
emerging markets. Most of the emerging markets are ripe for investment in agriculturerelated business activities. Hence, raw material is readily available locally with positive implications for increased profit due to low production costs alongside reduced tax.

Responses of participants is consistent with the findings of several studies by [40, 41]. These studies show that emerging market has peculiar characteristics that differentiate it from traditional market. As underscored by participants, emerging economies are vastly different from the developed economy with the traditional market such as the United States, Germany, Japan, and Mexico. For example, according to a report by [40], while emerging markets such as China, India, and Brazil's GDP are US\$8.83 per capita, the United States had US\$59.53. Likewise, World Bank (2019) indicated that Ghana had a growth rate of $6.7 \%$ in 2019 compared to the United States, Japan, and Germany's growth rate of 3\%.

In effect, the findings of the study revealed that emerging market is a market with low GDP per capita, reduced tax rate, accessibility to raw materials and cheap labour, and rapid growth rate. Notwithstanding, emerging markets are noted for certain constraints, which often discourages investments or diversification within the agribusiness sector.

Excerpts of Responses of participants below.

Emerging markets are often affected by political instability and other natural disasters which could be very fatal to our business.

The shifting sand of policies has made our work in buying and selling $100 \%$ cotton very difficult, culminating in meager profit. The government need to formulate and enforce relevant policies to remove illegal companies and encourage those with legal right to operate.

We have embarked on intensive training of our staff because most of them lacks adequate knowledge of the production process and how to generate enough patronage through adequate knowledge of market situation.

Themes generated from framework \#1 include.

1. An emerging market is not defined by geographical features but is characterized by lower-than-average per capita income. It includes China, India, and Ghana.

2. Opportunities of emerging markets exist reduced tax, cheap labour, raw material availability.

3. Opportunities of emerging market exist; minimised cost of production, lower product and service prices and increase patronage and profit.

4. Emerging market is affected by macro environmental constrains.

5. An emerging market is affected by macro environmental constrains.

6. Government must act.

7. Internal strength or capacity must be built to overcome constrains.

8. There is a lack of infrastructure framework.

9. Training enhances awareness and faster technology diffusion rate.

10. Developing economies have a mixture of labour costs.

Table 1. Reviewing, Defining and Naming of Themes

\begin{tabular}{|l|l|l|l|}
\hline Market Opportunities & Frequency & Market constrains & Frequency \\
\hline Reduced tax & 2 & Unstable policies & 5 \\
\hline Cheap labor & 2 & Political volatility & 2 \\
\hline Raw material availability & 4 & Poor ICT infrastructure & 5 \\
\hline Low production cost & 5 & Cost of training & 2 \\
\hline Diversification & 3 & Weak institution & 5 \\
\hline Rapid growth & 3 & & \\
\hline
\end{tabular}




\section{Discussions}

In-depth examination of the responses of participants reveals that though a majority (19) of the participants agreed that emerging market has several potential and benefits, yet they indicated that there are certain constraints mitigating increased investment in agribusiness in Ghana, as demonstrated in the excerpt. Reference was made to political instability or institutional voids with concomitant shifting sand of policies which has truncated growth in the agribusiness sector. This tally with [41] study that Ghana is "an enduring neopatrimonialism of a particular Ghanaian sort in which horizontal interest groups are subordinated to vertical patronage relationships" (p.1). This demonstrated that partisanship in Ghanaian politics has created weak institutions where office holders relegate the need of the citizenry to the background in order to observe the party's interest.

That is, the ability of public officials to formulate and carry out policies in accordance with the public interest is heavily constrained by the requirement to service patronage networks [41].

Several policies and ordinances that could have attracted local and international investors with a boost on foreign direct investment were not properly enforced or, in some instances, replaced upon transition from one government to the other. It clearly demonstrates the deplorable level of instability and volatility in the country. It lends credence to [42, 43] findings that inappropriate and unenforced laws and policies, alongside the poor level of skills in ICT limit the urge for investment in the agribusiness sector of Ghana. The low turnover or bankruptcy of several investors affected by illegal companies within the sector was used by [42] to concretize their point.

The result of the study is consistent with studies by [39] that emerging markets are noted for political instability arising from corruption and lack of transparency coupled with administrative delays during the process of registering business operation as well as enforcement of promulgated laws and policies.

Some members of one of the focus groups No. 1 comprising both management and nonmanagement staffs with 8 years working experience (on the average) posited that "Ghana's ICT infrastructure to boost modified technology that could have improve several aspects of agribusiness is lacking". For example, there are appropriate technology that could foster modification of seed or enhance growth rate for high yield. Another focus group member stated: "though we have state-of-theart technology in our establishment, but it has been an onerous task to use them because majority of our suppliers, customers and partners are not familiar with this modern technology, nor know how to use them".

A closer study of the excerpts and themes above, from my perspective, reveals that constraints limiting the establishment of an agribusiness organization in Ghana is both internal and external in nature. Some investors are constrained due to the low level of ICT infrastructure in Ghana, while others are constrained because their partners or customers are unfamiliar with appropriate technology, they have adopted to boost their competitive edge. From the focus group discussion, I discovered that upon integrating appropriate technology, all staffs and non-staffs must be trained on how to use the technology, whether it is a software or machine. To create awareness through adequate training programs, the organization would have to spend a huge sum of money with a concomitant reduction in their profit and turnover.

This finding is in harmony with Epting and Adner, and Kapoor that for the creation of value chain and competitive edge, an agribusiness company should build an enabling ecosystem wherein partners, customers, and lawmakers are willing to adopt the new technology and use it. This means the new technology should not contravene any ordinance in the country, and 
partners alongside customers are willing to use the technology or be trained on its usage. This is very important because the establishment cannot survive without an effective and wellfunctioning ecosystem that embraces its new technology and is ready to patronize its products.

Depicted in Figure 1 is the summary of the numerous opportunities and constraints associated with the creation of value in agribusiness in Ghana. This was drawn based on participants' responses.

A closer study of the chart in Figure 1 and 2 reveals that there are numerous opportunities and constraints associated with investing in agribusiness within the context of Ghana as an emerging market.

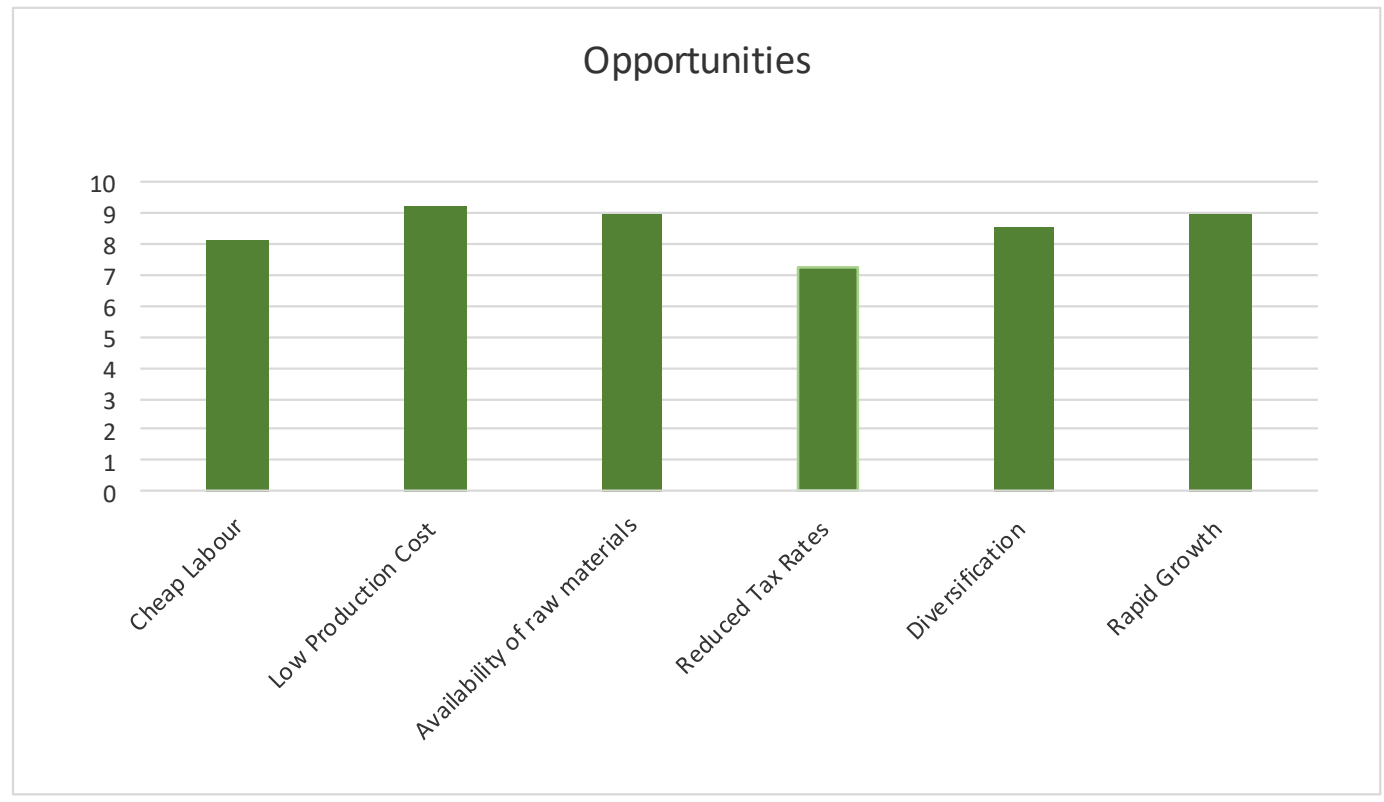

Figure 3. Potential Opportunities

Source: Researcher's Construct (2020)

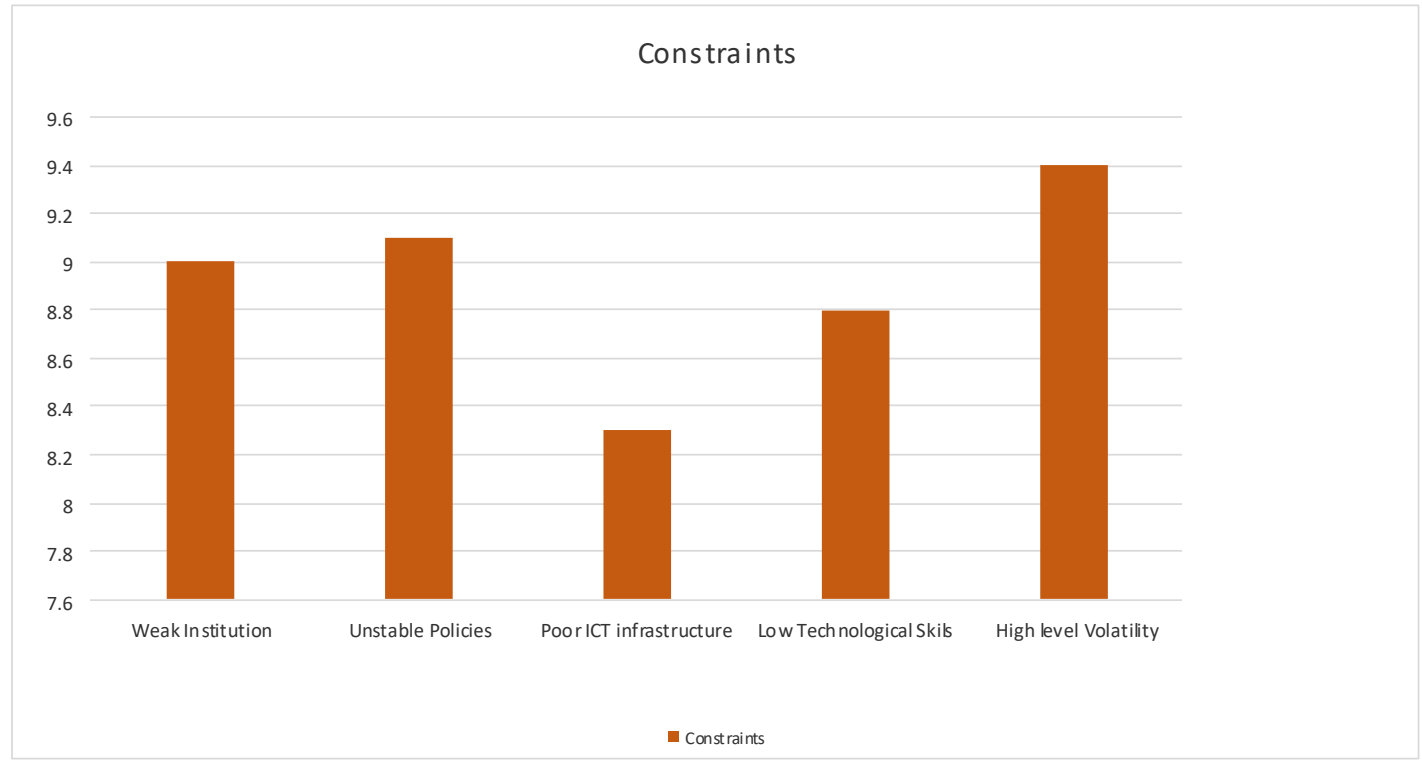

Figure 4. Potential Constraints

Source: Researcher's Construct (2020) 
However, the chart shows that in comparison to other forms of potential opportunities, cheap labour and reduced tax rates received a lower rating. One of the management staffs with 13 years of working experience intimated that "tax rates in Ghana is not necessarily low when compared to other developing countries like Nigeria or Togo, although lower in comparison to developed countries. He indicated that though the amount earmarked by the government could be low, but corruption by public office holders requesting for bribes makes the total cost paid for services higher with negative effect on profit.

Likewise, one member of the focus group No. 2 with 11 years of working experience, indicated that "cheap labour in Ghana is not clear-cut rather it is context-specific, certain locations in Ghana are prone to higher labour cost while others could be lower". This account for the reason why fewer participants agreed that there are cheap labour and reduced tax rates in Ghana.

\section{Conclusion and Implications}

Themes generated from the in-depth interview and focused group also suggested the cost of training or lack of technological skills and political volatility as some of the constraints. The deduced market potentials include, as seen from the table below, coded as blue.

Table 2. Opportunities and Constraints

\begin{tabular}{|l|l|l|l|}
\hline Market Opportunities & Frequency & Market constrains & Frequency \\
\hline Reduced tax & 2 & Unstable policies & 5 \\
\hline Cheap labour & 5 & Political volatility & 2 \\
\hline Raw material availability & 4 & Poor Tech infrastructure & 5 \\
\hline Low production cost & 2 & Cost of training & 2 \\
\hline Diversification & 3 & Weak institution & 5 \\
\hline Rapid growth & 3 & & \\
\hline
\end{tabular}

The findings of the study are consistent with the result of a study by $[2,19,21]$ that agribusiness organization should not only be concerned with internal constraints within the organization. They should also be concerned with external challenges arising from interdependent partners.

In a nutshell, the findings of the study revealed that there are several opportunities for investment in agribusiness in Ghana. It ranges from cheap labor, low production cost, availability of raw materials, reduced tax rates, capacity for diversification, and rapid rate of business growth. However, there are certain inhibitions or constraints limiting the urge for investment in the agribusiness sector in Ghana. These range from weak institutions, unstable and unenforced policies, poor ICT infrastructures, low technological skills, and high-level volatility.
I concur with the submissions of the participants. Ghana has put in place tax incentives to attract investors. One such incentive is the opportunity given to any agribusiness investor or firm to benefit from corporate tax holidays. These firms are free to register under the Ghana Free Zone Authority to enjoy exemption from income tax for about 10 years. Any company under the Free Zone is also entitled to $0 \%$ import duty on any machinery or technological equipment imported. Notwithstanding, as the participants indicated, in reality, due to corrupt practices by public office holders, investors are compelled to pay bribes before accessing tax concessions that they are entitled to, such as import duties. Notwithstanding, in comparison to agribusiness investment in developed countries, the government of Ghana made ample provision for reduced tax rates to attract investors. 


\section{Limitations of Studies}

Limited time to deepen the impacts each of the identified constraints will have on a new entrant's business processes to launch a valuedriven product into an emerging market, degrees of impact of each constrain could be measured and rated so appropriate resources will be spent on overcoming each element.

This was limited to the Agribusiness industry and hence cannot be generalized to other industries within the emerging market of Ghana.

Also, other empirical studies could be conducted utilising the quantitative approach to the research as this was biased towards qualitative approaches.

A lot of intended participants declined even after the promise of hiding their identity due to

\section{References}

[1] Mari S. (April 2015) Communications of the ACM, Vol. 58 No. 4, Pages 27-29 $10.1145 / 2736289$ Competing in Emerging Markets, April 2015, Communications of the ACM.

[2] Amankwa-Amoah, J., Debrah, Y. A., Yu, W., Adomako, S., \& Danso, A. (2020). Technology strategies in emerging economies: emerging issues, challenges, and new research. Elsevier B. V: Technological Forecasting and Social Change, 2 (1), p. 1.

[3] Cumming, Douglas \& Zhang, Yelin, 2016. "Alternative investments in emerging markets: A review and new trends," Emerging Markets Review, Elsevier, vol. 29(C), pages 1-23.

[4]Flint, G. D. (2000) What is the meaning of competitive advantage? Advances in Competitiveness Research, 8(1), 121-129. https://www.irbnet.de/daten/iconda/CIB4393.pdf.

[5] Klein, J., 2001. A Critique of Competitive Advantage. Manchester, Critical Management Studies Conference.

[6] Melissa A. Schilling (2015) Technology Shocks, Technological Collaboration, and Innovation Outcomes. Organization Science Published online in fear of their candid response going public and going against company policies.

\section{Acknowledgements}

Some Persons contributed substantially to work in this manuscript (e.g., technically, writing and reading and editing assistance, general), however, the help do not make the mark for authorship hence there were no acknowledgements as co-authors.

\section{Conflict of Interest}

Moreover, no financial and relationship conflicts of interest exist. The article is therefore balanced, objective, and evidence based as possible.

Articles in Advance 1st Apr 2015. http://dx.doi.org/10.1287/orsc.2015.0970.

[7] Sołoducho-Pelc L., Radomska J. (2012), The role of human capital in creating competitive advantage based on technology, ed... J. Kowal, N. Roztocki, Proceedings of the International Conference on ICT Management for Global Competitiveness and Economic Growth in Emerging Economies, pp. 161182.

[8] Sołoducho-Pelc L. (2013), Factors Determining the Process of Creating and Implementing a Strategy Based on Innovation and Technology, Vision 2020: Innovation, Development Sustainability, and Economic Growth, 21st IBIMA Conference 27-28 June, Vienna, Austria, pp. 442-454.

[9] Porter M. E. (1996). What is strategy? Harvard Business Review, November-December, pp. 61-78.

[10] Wang C.L., Pervaiz K. Ahmed (2007), Dynamic capabilities: A review and research agenda, International Journal of Management Reviews, Vol. 9, Issue 1, March, pp. 31-51.

[11] Chakravarthy, B.S. (1986) Measuring Strategic Performance. Strategic Management Journal, 7, 437-458. http://dx.doi.org/10.1002/smj.4250070505. [12] Ensign, P. C. (1998). Interrelationships and horizontal strategy to achieve synergy and 
competitive advantage in the diversified firm. Management Decision, 36, 657-668.

[13] Barney, Jay B. 'Is the Resource-Based 'View' a Useful Perspective for Strategic Management Research? Yes." The Academy of Management Review, vol. 26, no. 1, 2001, pp. 41-56. JSTOR, www.jstor.org/stable/259393 Accessed 13 July 2021.

[14]Peteraf, Margaret A. "The Cornerstones of Competitive Advantage: A Resource-Based View.' Strategic Management Journal, vol. 14, no. 3, 1993, pp. 179-191. JSTOR, www.jstor.org/stable/2486921 Accessed 13 July 2021.

[15]Hart, Stuart L. "A Natural-Resource-Based View of the Firm." The Academy of Management Review, vol. 20, no. 4, 1995, pp. 986-1014. JSTOR, www.jstor.org/stable/258963 Accessed 13 July 2021.

[16] Ankli, Robert E. “Michael Porter's Competitive Advantage and Business History." Business and Economic History, vol. 21, 1992, pp. 228-236. JSTOR， www.jstor.org/stable/23703225 Accessed 13 July 2021.

[17] Barney, J. B. (1991), Firm resources and sustained competitive advantage, Journal of Management, Vol. 17, No.1, pp. 99-120.

[18] Wright, P., 1987. A Refinement of Porter's Strategies. Strategic Management Journal, Vol. 8(No. 1), pp. 93-101 www.jstor.org/stable/258963 Accessed 13 July 2021.

[19] Anderson, James C., et al. "Dyadic Business Relationships within a Business Network Context." Journal of Marketing, vol. 58, no. 4, 1994, pp. 1-15. JSTOR, www.jstor.org/stable/1251912 Accessed 13 July 2021.

[20]Amankwah-Amoah, J. "The evolution of science, technology and innovation policies: A review of the Ghanaian experience." Technological Forecasting and Social Change 110 (2016): 134142.

[21] Amankwah-Amoah, J., 2015. Solar energy in sub-Saharan Africa: The challenges and opportunities of technological leapfrogging. Thunderbird Int. Bus. Rev. 57 (1), 15-31.

[22] Vijay M., Kamini B. Published Sep 14, 2005, by FT Press. https://www.informit.com/store/86- percent-solution-how-to-succeed-in-the-biggestmarket-

9780131489073?w_ptgrevartcl $=$ The + Lands + of + Op portunity_404802.

[23]Li, Shaomin, et al. "Corporate Social Responsibility in Emerging Markets: The Importance of the Governance Environment." MIR: Management International Review, vol. 50, no. 5, 2010, pp. 635-654. JSTOR, www.jstor.org/stable/41426815 Accessed 15 July 2021.

[24]Herrmann, Sabine, and Adalbert Winkler. "Financial Markets and the Current Account: Emerging Europe versus Emerging Asia." Review of World Economics / Weltwirtschaftliches Archiv, vol. 145, no. 3, 2009, pp. 531-550. JSTOR, www.jstor.org/stable/40587827 Accessed 15 July 2021.

[25]Kose, M., \& Prasad, E. (2010). Changes in the World Economic Order: A Roadmap. In Emerging Markets: Resilience and Growth amid Global Turmoil (pp. 1-8). Brookings Institution Press. Retrieved July 15, 2021, from http://www.jstor.org/stable/10.7864/j.ctt6wpd2g.5. [26] Azigbo, U. K., (2019). "Strategies for New Product Development in an Emerging Market" Walden Dissertations and Doctoral Studies. 6752 https://scholarworks.waldenu.edu/dissertations/6752

[27] Kothari (2004). Research methodology: Methods and Techniques. New Delhi: New age international (P) limited, publisher http://www.sciepub.com/reference/233432.

[28]Kumar, R. (2011) Research Methodology: A Step-by-Step Guide for Beginners. 3rd Edition. Sage, New Delhi. https://www.scirp.org/(S(oyulxb452alnt1aej1nfow45 ))/reference/ReferencesPapers.aspx?ReferenceID $=1$ 971596.

[29] Bonache, J. and Festing, M. (2020) 'Research paradigms in international human resource management: An epistemological systematisation of the field', German Journal of Human Resource Management, 34(2), pp. 99-123. Doi: $10.1177 / 2397002220909780$ 
[30]Babones, S. (2016) 'Interpretive Quantitative Methods for the Social Sciences', Sociology, 50(3), pp. 453-469. Doi: 10.1177/0038038515583637.

[31]Creswell, JW. 2014. Research Design: Qualitative, Quantitative, and Mixed Methods Approaches. Thousand Oaks: Sage Publications. https://www.scirp.org/(S(i43dyn45teexjx455qlt3d2q ))/reference/ReferencesPapers.aspx?ReferenceID $=1$ 964849.

[32] Yin, R. K. (2018). Case Study Research Design and Methods (6th Ed.). Thousand Oaks, CA: Sage Publishing.

https://www.scirp.org/reference/ReferencesPapers.as px?ReferenceID $=2398913$.

[33] Creswell, JW. \& Poth, CN. (2018) Qualitative Inquiry and Research Design Choosing among Five Approaches. 4th Edition, SAGE Publications, Inc., Thousand

Oaks. https://www.scirp.org/(S(lz5mqp453edsnp55rrgjct55 ))/reference/referencespapers.aspx?referenceid $=215$ 5979.

[34] Yin, R.K. (2016). Qualitative Research from Start to Finish, Second Edition. New York: The Guilford Press. ISBN: 978-1-4625-1797-8. 386 pp. https://doi.org/10.1111/fcsr.12144.

[35]Lohfeld, W. (2008). Review: Sharlene HesseBiber \&amp; Patricia Leavy (2006). The Practice of Qualitative Research. Forum Qualitative Sozialforschung/Forum: Qualitative Social Research, 9(1). https://doi.org/10.17169/fqs-9.1.363. [36]Nyumba, T., Wilson, K., Derrick, C., \& Mukherjee, N., (2018) The use of focus group discussion methodology: Insights from two decades of application in conservation. Methods in Ecology and Evolution, 9(1), pp. 20-32.

[37] Overlien C, Aronsson K and Hyden M (2005)

The focus group interview as an in-depth method?
Young women talking about sexuality. International Journal of Social Research Methodology 8(4): 331344.

https://journals.sagepub.com/doi/pdf/10.1177/00219 09619857098.

[38] Nowell, L.S., Norris, J.M., White, D.E. and Moules, N.J. (2017) Thematic Analysis: Striving to Meet the Trustworthiness Criteria. International Journal of Qualitative Methods, 16, 1-13. https://doi.org/10.1177/1609406917733847.

[39]Boso, N., Adeleye, I., Donbesuur, F., \& Gyensare, M. (2019). Do Entrepreneurs Always Benefit from Business Failure Experience? Journal of Business Research, 98, 370-379. https://doi.org/10.1016/j.jbusres.2018.01.063.

[40] World Bank Group (2017). Leapfrogging: the key to Africa's development? From constraints to investment opportunities. Retrieved on March 2, 2020, from

http://documents.worldbank.org/curated/en/1215815 05973379739/pdf/Leapfrogging-the-key-to-Africasdevelopment-from-constraints-to-investmentopportunities.pdf.

[41] Booth et al. (2005), What are the drivers of change in Ghana? CDD/ODI Policy Brief No. 1, November 2005 , https://cdn.odi.org/media/documents/1961.pdf.

[42]Francisco, A.H (Jan 24, 2010). Neopatrimonialism in Contemporary African Politics https://www.e-ir.info/2010/01/24/to-whatextent-can-neopatrimonialism-be-consideredsignificant-in-contemporary-african-politics/, pp. 2 . [43] Osseo-Asare, F. (1984) Development Paradigms and Realities: Agricultural Development Strategies in Ghana, 1957-1983, Paper presented in College Station, Rural Sociological Society. 


\title{
Strategy Behind the Business Success of Amazon: A Case Study
}

\author{
Chukwuka Sunday Ukeni \\ Department of Business Management, Texila American University, Guyana, Zambia
}

\begin{abstract}
The success of any business is dependent on the strategy/strategies that are deployed in the operation of such a business. Strategy is a critical determinant of business success. Amazon.com is one of the most successful brands in the world; the company has been in business for over two decades and has recorded an unprecedented business success in human history. In this research work, the key strategy behind the success of Amazon will be extensively investigated. Given the unusual success rate of this organization over the past two decades and their high prospect for greater success, it becomes imperative to investigate the strategy behind this tremendous business success in-order to unveil and/or re-emphasize an established business principle that may not be obvious to many businesses. The purpose of this research is mainly to identify these strategies and extend further emphasis on the viability of such business strategies in order to strengthen existing research on the subject matter. Using the waterfall methodology, the history of the company will be reviewed, the financial reports, company memos, press releases, etc., will be analysed. The evolvement of the business from its inception as an online book retailer to its diversification into numerous other lines of businesses will be reviewed and analysed.
\end{abstract}

Keywords: Amazon, Brand, Customer, Management, Strategy, Success.

\section{Introduction}

The purpose of this research is primarily to fulfill part of the requirements of my MBA program on Strategic Management/International Business with Texila American University.

When the success of Amazon is considered and discussed today, it will be difficult to believe that it all started at its founder's garage. Yet that's exactly where Jeff Bezos floated the online bookstore that has now culminated into a worldclass phenomenon.

At the preliminary stages of the company, Bezos and his then employees would gather books and convey them to the post office themselves, and even after the company began to build warehouses and acquire more assets, many investors still wrote off the venture as dead on arrival, especially because of the dominance of brands like Borders and Barnes \& Noble, so it was believed they would be wiped out by the existing popular brands.
Instead, major brands like Borders and Barnes $\&$ Noble later filed for bankruptcy protection in 2011 and are almost no longer in business. Meanwhile, Amazon has not only excelled in their first line of business but has widened their reach to cover almost every conceivable kind of product, media, and service. Some study shows that as of 2018, it accounted for nearly half of online retail. This information retrieved from eMarketer further revealed that in that period, Amazon was laying the groundwork for a physical retail business.

In their last 26 years of operation, Amazon's progression from bookseller to the world's leading eCommerce marketplace has been mindboggling, even though - according to the architect of its rise - building the "everything store" was all part of the plan from the beginning.

Considering the outstanding success of the company as briefly highlighted above, the strategy behind this compelling business success 
is one that should not only go unnoticed but also worth studying, especially for a student seeking any form of degree in the field relating to the subject of strategy, such as Strategic Management.

The research takes a look at the Amazon brand as a case study. It covers the operation and activities of Amazon.com from the inception of the company to date, with an aim to identify the major strategy(s) behind its outstanding success in business. In the course of the study, the annual financial statements of the company were analyzed, as well as the company's policies on customer relationship management, human resource management, etc. A critical area that was given attention is the area of product development and how it has contributed to meeting the company's vision and goals. The results of the company's performance in line with its strategy and policy implementation was analyzed and presented in the study. The company's expansion programs and procedures from America to different parts of the world was analyzed, and the results were presented. Another vital area that was covered is a study of the founder of the company and his ideologies and how it has contributed to the business success. The experience and leadership style of the company as well as the organizational culture, was analyzed to understand how it has contributed to the entire business success. The study was concluded by highlighting sufficiently the key strategy that is behind the business success of the company and how the same strategy can be adopted by other businesses around the world, to drive the realization of their vision and goals. It also attempted to show how Amazon has consistently followed this strategy in its business operations to date.

There are various existing researches on Amazon and its business success, many of which were consulted during the research. However, this is an addition to existing research as it focused mainly on the key strategy(s) behind the success of Amazon and how it can be replicated by other businesses around the world.

\section{Materials and Methods}

Many researches have been conducted on the success story of Amazon.com, a 26-year-old brand with an outstanding business performance that sets a standard for the global business space in general and the e-commerce industry in particular. The company is the largest ecommerce business in the world today, and the evolvement of the brand over the years to reach its present level of success has caught the interest of many researchers, as such, it has become a major subject of research globally.

According to existing research and available information, Amazon.com officially began operation on July 16, 1995, as an online bookseller. By August 31 of the same year, the company had shipped books to all the 50 states in America and to the other 45 countries in the world. By December 1996, the company had reached 180,000 customers after its full year in operation, and less than a year later, in October 1997, it had one million customer accounts. The number of customer accounts has grown to over 76 million as at October 2020.

Although existing research provides elaborate information about the business strategy of Amazon, the key strategy(s) that has been consistent from the inception of the company till date, which in my opinion is largely responsible for the long-term success of the business, still needs to be further investigated. Furthermore, the business ideologies of the founder that have remained consistent to date also have to be investigated, as the outcome of these investigations will serve as an additional and effective tool (working principle) in the arsenal of strategic business consultants, CEOs, and business managers. The study of strategic management will come to life when such practical business strategies are investigated to validate the principles already taught and practiced in the field. 


\section{The History of Amazon.com}

According to [1], Amazon officially began in July 1995 by Jeff Bezos, who did not know much about the internet at the time (even though he was a graduate of computer science), but came across a statistic that the internet was growing at $2300 \%$, and was convinced by this statistics to take advantage of the opportunity. However, [2] found that the Amazon brand was actually born on July 5, 1994, but officially commenced operation in 1995. The findings of [3], also agree with this. However, it further reveals that the name Amazon.com was officially registered on November 1, 1994 by Jeff Bezos and his wife, after considering and registering domain names like Awake.com, Browse.com, Bookmall.com, and Relentless.com in an attempt to choose the best name for the brand. He also found that the name Amazon.com (co-named after one of the largest rivers in the world) was chosen by the founder because it was fitting to his vision of building the largest online store in the world.

\section{The Early Breakthrough of Amazon.com}

According to [2] Amazon went public at $\$ 18$ per share, giving it a valuation of $\$ 300$ million. However, after adjusting for three subsequent stock splits, the closing stock price of Amazon on their first day of trading was $\$ 1.96$. The Podean Marketplace on its website (June 2020) validated the above fact but also emphasized that If one were to have invested $\$ 1,000$ into Amazon shares (IPO) in 1997, those shares would have grown in value to over $\$ 1,137,000$ by the end of 2019. This illustration was done to provide further insight into the level of breakthrough Amazon has achieved.

[3], in his paper, disclosed that by December of 1996, Amazon's customer base had grown to an impressive 180,000, and by October of the following year, this figure had leaped to around $1,000,000$ registered accounts. He also disclosed that Amazon's revenues had reached around $\$ 148$ million in 1997, a significant jump from around \$16 million in 1996. Prior to this time,
Amazon had remained a private company. But Bezos soon realized that to sustain the company's growth, and he would need more than just private investment. To this end, in 1997, Amazon.com went public and was able to raise a whopping \$54 million on the NASDAQ exchange. In addition to the cash, the company leveraged on its high-flying stock to fund its aggressive growth and acquisition strategy. By 1998, Amazon's revenues had reached a record $\$ 600$ million.

Amazon's outstanding rise within such a short period of time catapulted Bezos into prominence. He was also chosen to be Time magazine's 1999 Person of the Year.

According to [2], as the demand for their products and services increased, Amazon unveiled a second distribution center in November 1997 at New Castle, Delaware, in order to widen to market coverage. The business soon spread to China, Germany, UK, etc. to about 152 countries of the world.

[4] found that Amazon expanded rapidly in other areas as well. Its Associates program, which provides a platform for other Web sites to offer merchandise for sale, whereby Amazon.com would fill the order and pay a commission, grew from a mere site in 1996 to more than 350,000 by 1999 . [5], further reveals that In 2000, the U.S. toy retailer Toys "R" Us signed a 10-year business agreement with Amazon, valued at $\$ 50$ million per year, under which Toys "R" Us would be the sole supplier of toys and baby products on the service, and the brand's website would redirect to Amazon's Toys \& Games category.

\section{Financial Records and Performance of Amazon.com}

[3] and other researchers agree that Amazon.com did not make a single profit until the last quarter of 2001, despite the huge success that characterized the business venture. [4] added that this situation appeared to justify the early criticism and scepticism that met with the 
business at the onset from financial journalists and analysts who even went to the extent of referring to the company as Amazon. Bomb; Many of them claimed Amazon.com ultimately would lose in the marketplace to established bookselling chains, such as Borders and Barnes \& Noble, once they launched competing ecommerce sites, and the lack of profits until 2001 looked like a confirmation to these predictions. Moreover, [6] confirmed that the company did make its first quarterly profit of $\$ 5.8$ million in the fourth quarter of 2001, but this was dwarfed by large cumulative losses. He further presented the historical income statements, historical balance sheets, and the historical cash flow statements of the company from $1997-2001$ as follows:

1. Sales grew from $\$ 147$ million in 1997 to about $\$ 3.1$ billion in 2001 .

2. The average growth rate during this period was $141 \%$.

3. The gross margin during this period had averaged $21.68 \%$.

4. The ratio of marketing expenses to sales revenue had decreased from $16.33 \%$ in 1997 to $4.43 \%$ in 2001 .

5. Interest expenses had risen from $\$ 326,000$ in 1997 to $\$ 139$ million in the year 2001.

6. Loss from operations had increased from $\$ 32,595$ in 1997 to $\$ 412,257$ in the year 2001.

7. Sales from books, music, and video had levelled off. But this was a very profitable segment. On the other hand, the electronics, tools, and kitchen segment were growing rapidly- but were not very profitable.

According to the Amazon financial statements published by Macrotrends [7], Amazon has gone ahead to remain profitable from 2001 till date. A review of the financial statements of the company in the last six years shows that the company generated a net profit of $\$ 8.5$ billion in 2015 , which grew to $\$ 12.3$ billion in 2016 , and further grew to $\$ 15.5$ billion in 2017 , and then to $\$ 27.7$ billion in 2018 and further grew to $\$ 36.3$ billion in 2019 and finally grew to $\$ 48.1$ billion in 2020. Although the year 2020 came with a global lockdown that resulted in a global economic crisis which led to a massive collapse of businesses, job losses, and an increase in the cost of operation as a result of palliatives, rebates, and welfare of workers, Amazon.com remained significantly profitable.

The mere fact that the company survived for six whole years without making any profit from its inception attests to the financial competence of the Management and the formidability of the business model and strategies.

\section{Products \& Services of Amazon.com}

A study of the research work of [3] and others on the products and service line of Amazon revealed that at the onset of the company, Jeff Bezos (Founder) knew he wanted to build an online retail market, but he wasn't sure what exactly to sell on the platform, however, after some research and consultations, he settled for books because they were easier to source, package and distribute. But then, Amazon was not the first company to hit on this business strategy. Another company, Computer Literacy (a Silicon Valley bookstore), commenced sales of its own wares online as far back as 1991, but the difference with the business model and approach of Amazon.com was that it offered users greater convenience, as it was structured to deliver online orders directly to the customer's address anywhere in the world.

Moreover, [4], discovered that although Amazon.com famously started as a bookseller, Bezos maintained from its inception that the platform was not merely a retailer of consumer products. On several occasions, he was found saying that Amazon.com was a technology company whose business was simplifying online transactions for consumers. And as a result of this, the company will begin selling more than just books. The company commenced the sales of music and video in 1998. Within the same year (1998), it commenced its operations 
internationally with the acquisition of online booksellers in countries such as the United Kingdom and Germany. In the year 1999, the company had commenced the sales of consumer electronics, video games, and other related products. In the year 2002, the company introduced the sales of fashion-related products and further launched Amazon Web Services (AWS); a service that initially offered statistical data on Internet traffic patterns, most visited websites, and other relevant statistics for developers and marketers. In the year 2006, the company widened its AWS portfolio by integrating the Elastic Compute Cloud (EC2), a service that rents out computer processing power in small or large increments. That same year, the Simple Storage Service (S3); a service that rents data storage over the Internet, was included in their overall package. S3 and EC2 recorded immediate success and helped to propagate the idea that companies and individuals do not need to own computing resources; they can rent them as needed over the Internet, or "in the cloud." For example, in 2007, immediately after launch, the S3 service had over 10 billion objects or files; five years later, it held over 905 billion objects. Today, AWS is serving a few of Amazon's major rivals, such as the likes of Netflix, which makes use of both S3 and EC2 to compute its video streaming service.

[4], further revealed that when Bezos founded his company Amazon.com, the strategy was not to move inventory around. However, in order to establish a measure of control over deliveries, the company in 1997 started keeping inventory in its warehouses. In the year 2000, the company introduced a system that allows small companies and individuals to market and sell their products through the resources of Amazon.com. By the year 2006, it had commenced its FBA (Fulfilment by Amazon) service, a service that manages the inventory of businesses that market and sell their product through Amazon.com. The growth of its inventory-management business influenced its purchase of Kiva Systems (a robotics company whose devices automate inventory-fulfilment duties) at a whooping sum of \$775 million in 2012. In 2007 Amazon.com introduced the sales of its own Kindle e-readers, which helped energize the e-book market. In the year 2011, the company launched a related but affordable tablet computer: the Kindle Fire, and by 2012 , the Kindle Fire was estimated to have accounted for over 50 percent of the tablets sold with Google's Android mobile operating system.

After operating its first full year of selling books in 1996, publishing firms commended the new service as a leverage for them to clear their backlog of slow-selling books. In the year 2009, the first publishing line of the company, known as Amazon Encore was introduced, and it gave priority to popular self-published books as well as books that are out of print. It also afforded individuals the liberty to publish their own ebooks. In the year 2011, its e-book drive resulted to the emergence of Amazon Publishing, which was set up with the goal to develop and publish its own titles. That year, it was discovered that the e-books on Kindle were outselling the printed books. Although many book publishers has continued to enjoy revenue surge through sales at Amazon.com, the company is however seen as a major competitor in their industry.

In the year 2017, Amazon.com disclosed that it has reached an agreement to acquire the supermarket chain - Whole Foods Market, Inc., in a deal valued at over $\$ 13$ billion. Nonetheless, despite the fact that they have reached out well beyond online retailing, the larger chunk of the company's revenues are generated through the sales of products online (though its most profitable segment remains AWS), and that has been the target for most of its investment. Over the years, the company has either acquired or invested hugely in many online retailers, such as the renowned shoe seller Zappos, which was purchased for $\$ 847$ million in 2009.

Perhaps one of the most successful and profitable initiatives of Amazon, as seen in the research work of [2], is the \$79-a-year loyalty 
program that includes free two-day shipping on any order, announced by Jeff Bezos in 2005. Today, Amazon Prime has more than 100 million members worldwide, and it is considered as one of Amazon's most valuable assets. According to the Podean marketplace, Prime has proven to be a massive success: it now has more than 112 million members across the globe. The beginning of Amazon Prime resulted to the widespread of concept of customer appreciation and loyalty towards the company. The vision and goal of the company on customer obsession and ultimate customer satisfaction became a reality through the Prime project. To put it simply, the convenience and ease that Amazon Prime offers is the ultimate expression of Amazon's quest to deliver absolute satisfaction to its customers. In the year 2019, an average member of Amazon Prime in the U.S. spent about $\$ 1,400$ on Amazon.

[2] also has it that after being blamed for the decline of independent bookstores across the country, Amazon in 2015 opened its own physical retail location in Seattle. The store was opened as part of their strategy to market the company's growing list of electronic devices as well as to sell their books. Amazon currently owns and controls about fifteen major bookstores in the United States.

According to [5], In November 2020, the company started an online delivery service exclusively for prescribed drugs. The service provides discounts of up to $80 \%$ for generic drugs and up to $40 \%$ for branded drugs for active Prime users. The products are available for purchase on the company's website or at over 50,000 bricks-and-mortar pharmacies in the United States.

As at today, Amazon.com has successfully developed a number of products and services available, some of which include: AmazonFresh, Amazon Prime, Amazon Web Services, Alexa, Appstore, Amazon Drive, Echo, Kindle, Fire Tablets, Fire TV, Video, Kindle Store, Music, Music Unlimited, Amazon Digital Game Store, Amazon Studios and AmazonWireless.

\section{The Business Concept and Strategies of Amazon.com}

A review of the research work of [6] the reason behind the initial location of the company in Seattle, as revealed by the founder, was because of the availability of a large pool of technical talent and its closeness to one of the largest book wholesalers within the region at Roseburg Oregon. This actually confirms the fact that at the onset, he was thinking about the company as a bookseller. In addition to this, the sales tax laws for online retailers at the time was also a contributory factor in deciding the location of the company. As a result of this, cities like New York and California were ruled out of the options. This particular decision led to the quick growth of Amazon, because the possibility of stiff competition, which is a major growth threat, was eliminated from the onset.

[6], further disclosed that at the first attempt to name the company, the name Cadabra was chosen by Bezos. However, he would later discontinue with this choice when it was erroneously written as cadaver by a lawyer he engaged. He chose Amazon considering that it begins with the letter A, which is not only easy to apprehend and spell, but also signifies something big. According to the Podean Marketplace (2020), the decision to go with the name Amazon was later followed by Bezos because the name was taken from the largest river in the world (River Amazon in South America), which depicts his vision to build the largest bookstore in the world. The idea was crystallized while he was going through the dictionary, giving attention and priority to names that began with the letter " $A$ " because he believed this would be to the advantage of the company to be listed higher in alphabetized lists. This reflects the leadership quality of the founder of Amazon, which explains why Amazon has remained at the top since it got there.

Various researchers, including [4], reveal that although Amazon.com famously started as a bookseller, Bezos maintained from the start that 
the company was more than that. He always brought the wider perspective of what Amazon.com represents, which according to him was a tech company operating with the goal of offering simplicity and convenience to consumers in doing online transactions. Their inclusion of more and more products widened their reach to more and more customers. This also reflects the leadership quality of the founder and explains the reason why the company introduced many other products and services that eventually positioned the company to become profitable with a record of consistent and significant growth from 2001 till date.

[6], presented the two elements of Amazon's vision as follows:

1. To build the world's most customer-centric company

2. To establish a place where customers could buy anything.

In the words of Bezos, the vision was presented thus- "Our goal is to be Earth's most customer-centric company. I will leave it to others to say if we've achieved that. But why? The answer is three things: The first is that customer-centric means figuring out what your customers want by asking them, then figuring out how to give it to them, and then giving it to them. That's the traditional meaning of customercentric, and we're focused on it. The second is innovating on behalf of customers, figuring out what they don't know they want and giving it to them. The third meaning, unique to the Internet, is the idea of personalization: Redecorating the store for each and every individual customer. If we have 10.7 million customers, as we did at the end of the last quarter, then we should have 10.7 million stores." Again, the leadership quality of the founder is seen here, and Amazon has been able to effectively achieve this vision with the Amazon Prime project. This is the key strategy behind the success of Amazon.

[3] reports that the main goal of Amazon at the onset was to simply to offer convenience. The ease of searching, selecting, purchasing, and taking delivery of products from the comfort of your home, was an amazing innovation at the time. Another selling point for Amazon at the time was its recommended product function. By marketing products with the purchase history of users, they were able to significantly grow their revenue. The inclusion of initiatives such as product reviews by existing users further helped to foster a kind of "customer community" that made the site, and its wares, more appealing to potential customers.

\section{Research Approach}

This primary objective of this research was to investigate the strategy(s) behind the business success of Amazon.com, the largest online retail store in the world. The research was a basic one, but not new because numerous pieces of academic and business research exists, regarding the remarkable success story of Amazon.com. As such, the proposed research took the form of a new research but on an existing research subject. In order to fulfill and satisfy the above objective, a combination of qualitative and quantitative research approaches was used. Although this research is more qualitative because of the exploratory nature of the objective, however, quantitative data was also used to support some of the facts, figures, and statistics, like the financial statements of the company for the past 20 years. The research was be developed completely with secondary data that are descriptive in nature since all of the data needed have already been provided by previous researchers and from other valid sources like the company's website and Wikipedia.com.

\section{Data Collection}

In order to extensively answer the research question, existing data (documents, records, publications, etc.) was relied upon, since there are numerous data that have been put together already about the company by other researchers, due to the attention attracted by the company as a result of its remarkable success in the business and economic space. Hence, all the other forms 
of data collection was unnecessary for this research work. Materials that covered areas such as the history of the company, the business strategies and policies of the company - fully capturing the vision and mission statement of the company, as well as the financial statements of the company and records of key interviews with the founder and CEO of the company, was analysed in the research. Many of the data used were produced and published directly by the company (like the financial statements), while others were developed and published by other researchers. The materials were gathered from valid and trusted sources such as the company's website, Wikipedia, and other business-related websites and research papers.

\section{Data Analysis}

The data collected was analyzed using the content and thematic data analysis method. The data was broken down into about five different themes, and each theme was developed according to the most consistent information from the data.

\section{Results}

The study so far has led us to the answer to the research question. The success of Amazon is hinged on three key strategies:

1. Customer Centricity

2. Technology Focused

3. Exceptional Management

Amazon is known today as the largest and most successful e-commerce retailer in the western world, and they achieved this by building the best customer experience. The motto and mantra of Amazon is customer happiness. The mission statement captures it thus: do whatever it takes to make the customer happy. Amazon has embraced and deployed the best technologies available in achieving its mission. Initiatives like Amazon Prime, Amazon Robotics, the Buy Box, and a whole lot of other initiatives that define the remarkable success of the company are technology-based. More so, the consistency of the owner and the team of
Management experts at Amazon in pursuing the above vision and mission statements to date reflects the impact of running a business with an exceptional team of Management, and how such strategy can contribute significantly to the success of the business.

\section{Discussion}

The above-identified success strategies will each be discussed and analysed in line with Amazon's operations and activities. However, the key strategy that has contributed to the success of this company is Customer Centricity, and the other strategies were only developed to ensure this strategy is not only realized but realized in an unprecedented manner. Today, the success of Amazon has drawn the attention of the business world to the importance of making customers a priority as a strategy of success, and this idea has since grown into a business principle that is widely accepted by all available business research.

\section{Customer Centricity}

Customer centricity is an organizational strategy, model, and mind-set that places customers, rather than product or sales, at the center of the business. When a business is operated with a customer-centric culture, it doesn't think of customer-centricity as something to achieve later, neither do they think of it as the outcome of good customer service delivery. They approach customer experience strategically and intentionally, such that the customer is enthroned from the start. An organization that is customer-centric operates in such a way that every person and process within the entire organization: whether or not they are customer-facing, are involved in planning and delivering the customer experience. In a customer-centric setting, every employee is trained to focus on the delivery of exceptional customer experience in order to build loyalty and encourage repeat business. Although people often think about customer experience solely within the context of customer service, sales, 
marketing etc., it goes beyond that. True customer-centricity is an organizational approach where the job of every employee (including those that do not interface with customers directly), is done in the best interest of the customer. In a customer-centric organization, the customer is the priority and the center, and every employee functions with this understanding and focus. This is vital in achieving business success in the long term. The focus in decision-making and policy direction always puts quality customer experience at the center. There is a close relationship between the customer service practices of a company and its profits; according to [8], customer-centric companies are $60 \%$ more profitable than their counterparts. Customer centricity can be well explained with the aid of the following diagrams that present an accurate picture of what the concept is all about:

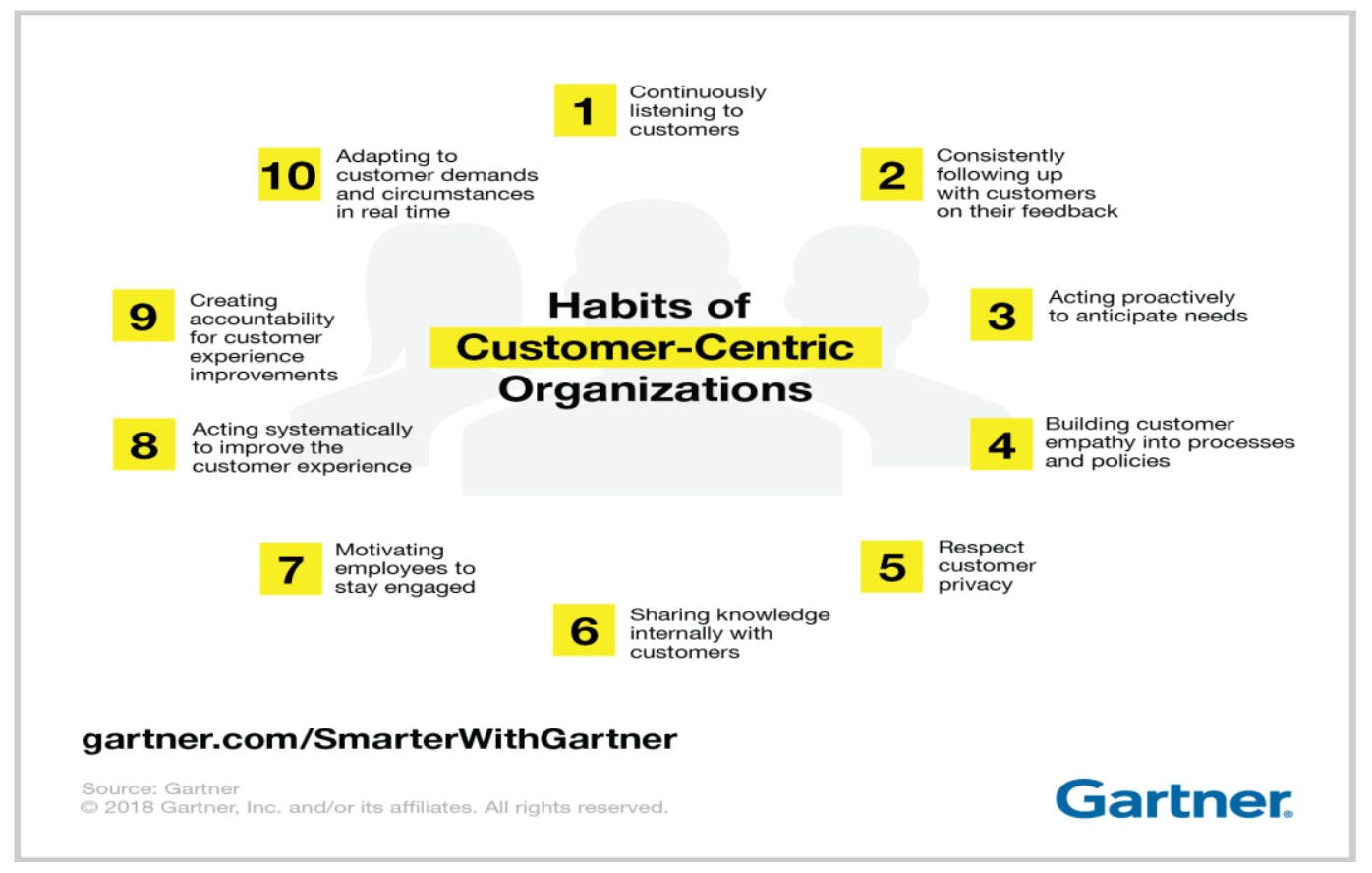

Figure 1. Habits of Customer-Centric Organizations

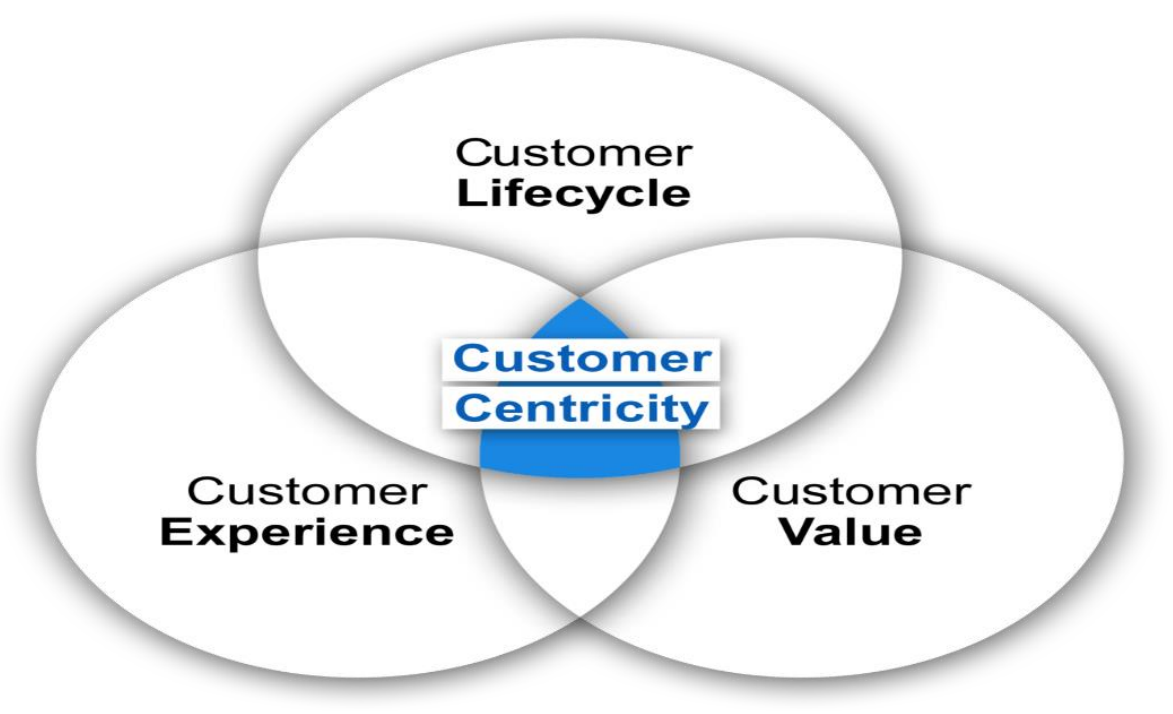

Figure 2. Customer Centricity 
Customer Centricity as described above involves putting the customer at the center of the vision statement of the company, as well as on the normal daily processes (such as the products/services offered, the mode of communication, the channels adopted, etc.) in order to strengthen the customer relationship.

There are three key elements that drive the concept of customer-centricity. The first element is customer experience. This is the sum of all experiences or interactions a customer has with a company, both online and offline. The second element is customer value, and this refers to the total value of a customer, both actual and potential value, both directly and indirectly (referral value like promoting a company, the influence on social media, etc.), and the third element is a customer life cycle, which refers to the evolution a customer goes through as defined by one or more aspects related to his or her needs (life stages, lifestyle, and relationship with company).

\section{The Culture of Customer Centricity in Amazon}

The description of the concept of customer centricity reflects the actual business practice of Amazon in its entirety. The business model and decision-making processes of Amazon are a practical definition of customer-centricity. For example, the key element of the vision of the organization is to build the world's most customer-centric company, and to a very large extent, this vision has been achieved today.

The approach to the successful implementation of this strategy is known as the Amazon Flywheel, and it is summarized below:

There are three major things customers consider when buying products online:

1. Large Selection: This ensures that consumers are able to find the products they are looking for.

2. Low Price: This ensures that the product is affordable to consumers.
3. Fast Delivery: This ensures that the consumers get their orders quickly.

If customers are given a quality (and consistent) shopping experience online, they will always return again and again and also refer their friends. This generates Traffic. Sellers will always flow with traffic, because they need to market their products to potential consumers. More sellers mean more product selection.

More product selection means a better Customer Experience (they have everything). With three of these elements in place, the growth of the platform is assured because of economies of scale, which implies lower cost structure, leading to lower prices, and the final outcome will be the ultimate growth cycle, achieved by offering the best Customer Experience to customers. Amazon's success was established on service to the customer and the customer alone.

\section{Product Selection}

Having the world's largest store entails having the world's best selection. But, this is easier said than done. The smaller number of products results in higher margins and higher returns while many others generate very little or none at all in most stores and product line. This is known as: the Fathead versus the Longtail problem. Limiting your product selection to those highdemand high ticket items as they generate the most profit might be tempting. The issue, however is that these high ticket items are not what consumers buy every day, and when they do, they always buy them from a retailer that is known and trusted. To build consumer's trust, you will have to offer a series of consistent and positive shopping experiences. Amazon seeks to earn consumer's loyalty so that they buy everything there. Amazon's success depends on the fact that it is two very different but seamlessly integrated shopping places at once: A store, like Walmart (with Vendors providing products to Amazon) and a marketplace, like eBay (with Sellers selling directly to consumers).

\section{Price Factor}


Pricing is one of the most important factor that drives sales. As part of their commitment to provide a quality consumers' experience, they aim to offer the lowest price on the internet. They are succeeding with this. The Buy Box fosters competition within the platform to keep prices low. The Buy Box is a feature that has helped to keep the Amazon user interface tidy despite hosting a variety of sellers on the platform.

It works in such a way that each unique product has only one product page despite representing several listings. When the "buy" button is clicked by a user, the purchase is automatically directed to the seller who has won the Buy Box (red). The implication is that winning the Buy Box gives the seller a significant sales advantage, with the chances of winning about $85 \%$ of the sales for that particular item. The remaining sellers without the Buy Box will have to compete on the other $15 \%$ of the sales. Three key factors determine the winner of the Buy Box - price, rating, and delivery speed. To offer comparatively low pricing as a seller is one of the important determinants of winning the Buy Box. Uncompetitive pricing will significantly affect sales.

\section{Delivery Factor}

Asides from low pricing, the major delight of online consumers is quick delivery. Maintaining records of quick deliveries is instrumental in creating a consistent and reliable shopping experience. This is a challenge for many businesses.

There may be little (or no) infrastructure available in a business to achieve this, irrespective of the fact that they may be accustomed to selling only in bulk shipments or operating in a very small scale. These diverse circumstances notwithstanding, many users find it hard to distinguish between items "sold by Amazon" and "marketplace purchases". The implication is that for Amazon to get a consistent result, their shipping strategy will be adopted in selling other products.
The above arrangement is what is known as Fulfilment by Amazon (FBA). Controlling the process of storing, picking, packing and shipping enables Amazon to ensure that consumers get a quality delivery experience, and at the same time offering a solution to the sellers, who usually will struggle to deliver their goods going by the tough standards of Amazon.

This means that Amazon can always guarantee quick and accurate delivery as often as always. Any seller that opts in must ensure that their products are eligible for free shipping and Prime. Amazon Prime involves a subscription model that offers a 2-day free shipping on selected products. The service can currently be accessed in the United States, United Kingdom, Germany, Austria, India, Japan, Italy, Spain, and France. Amazon's idea is that the quicker the products arrive, the happier customers will be. This certainly seems to be true. Sellers often target to be listed on the Prime because it increases the likelihood of landing the Buy Box - and the lion's share of sales.

Amazon's brand is built on customer satisfaction. The goal is to earn the record of being the most customer-friendly company on the entire planet. The implication is that Amazon will be positioned as the company that offers the most convenience with the lowest prices and the best customer service out there.

\section{The Results of Customer Centricity at Amazon}

Amazon's strength is found in their relentless effort and commitment towards achieving a quality customer experience. Everything that Amazon does: every strategic move, every investment, is guided by its goal to be the most customer-centric company in the world. Every step, decision, and policy are geared towards benefiting and serving customers as best as possible. A lot of positive results have followed this initiative, some of which will be highlighted below:

\section{Data}


The sheer amount of data that Amazon has on consumers is mind-boggling. Beyond using the data to improve the efficiency of operations and improve the product offering, Amazon also sells the data for the purpose of publicity and advertisement through the Amazon DSP program.

\section{Prime Membership}

Consumers love Amazon, and there is high customer loyalty to the company, especially among the Prime members. Consumer Intelligence Research Partners (CIRP) discovered in their recent survey that over 100 million people resident in the United States have Amazon Prime accounts. I

The data also shows that approximately $58 \%$ of Amazon Prime Members pay the full $\$ 119$ yearly fee, while $36 \%$ pay for the monthly fee, and the remaining $6 \%$ are on a free trial. Further data from CIRP has shown that Amazon Prime members spend double the amount spent by nonprime members do-averaging $\$ 1,400$ per annum.

\section{Worldwide Recognition}

Amazon wields enormous power in whatever new market it enters. Amazon's global brand recognition provides them with such leverage that it poses a danger to new markets. Amazon presently has a 31 percent market share in Germany. In the United Kingdom, the company has a 47 percent market share.

So far, Amazon has achieved and still achieving this goal, and this has resulted to a strong brand. In 2019, about 2,000 US shoppers were surveyed, and it was shown that about $89 \%$ of the customers prefer to buy their products from Amazon than from other e-commerce sites. The survey also discovered that Amazon was designed in such a way that it had become indispensable in the customer's journey, this is proven through their customer review system.

According to [9] : Two-thirds of respondents (66\%) often begin their search for new products on Amazon, whereas one-fifth (20\%) begin on a search engine such as Google. When shoppers are ready to buy a specific product, $74 \%$ go straight to Amazon.

\section{Customer Centricity and Corporate Social Responsibility (CSR)}

A comparison of the speech of Amazon's CEO in their annual report of 1997 after the company went public, and the speech of the CEO in their annual report of 2020 when the whole world experienced a deadly pandemic, reveals how consistent the company has been in achieving its vision of customer-centricity, and it also depicts the length they are willing to go to sustain this legacy. Amazon had clearly gone beyond creating the best experiences for their customers, to taking responsibility for their customers' welfare and survival when it mattered most through a measure of palliatives and CSR programs.

\section{Highlights of the CEO Speech in the 1997 Annual Report}

Amazon.com passed many milestones in 1997, and by the end of that year, more than 1.5 million customers had been served, yielding $838 \%$ revenue growth to $\$ 147.8$ million, and the market leadership was extended despite the aggressive competition.

The excerpts from Jeff Bezos speech in the 1997 annual report retrieved from [10] shed more light on the extent Amazon has gone (and is willing to go) in their customer-centric approach.

\section{Highlights of the CEO's regarding Amazon's response to the COVID-19 pandemic}

At the peak of the negative after-effects of COVID-19 in the year 2020, Jeff Bezos gave a rousing speech in this report to motivate, inform and forge a direction for staff, clients and shareholders. This further shows how far the company can go in maintaining their customercentricity approach. The excerpts from the speech can be found in [11]. 


\section{Technology}

In building a business that provides the best customer experience in the world, one strategy Amazon has embraced and deployed greatly to achieve this feat is focusing and leveraging on technology. The technology involves deploying scientific knowledge for practical purposes such as use in industry and other areas of life. In essence, anytime we use scientific knowledge to some productive end (to achieve a particular purpose), technology was in operation. Technology covers the actions taken to meet human needs, while science is concerned with the understanding of how the natural world works. It can also be seen as the collection of techniques, skills, methods, and processes which can be deployed towards the production of goods or services and also for the accomplishment of specific objectives. The knowledge of techniques, processes, and the like is one aspect, while the embedding of the processes and techniques towards the operation of machine or equipment without the knowledge of their workings is another aspect. The Internet is a very good example of technology because makes information available in real-time, which is accessible by anyone anywhere in the world in a matter of seconds.

\section{The Results of Technology Investment at Amazon}

One of the frequently asked questions about the operations of Amazon is how they manage to deliver so quickly, given the volume and the scope of their transactions. The answer to this question lies in their use of sophisticated technology. Amazon is currently controlling one of the major Fulfilment networks in the world, and this is as a result of the following:

1. Advanced Logistics.

2. Innovative technology, powered by Amazon Robotics.

3. 175 fulfilment centres worldwide operating 24 hours.
Logistics: The logistics system of Amazon is completely superior to any other logistics system available in the world, and this is one of the major factors that has enhanced their ability to achieve the goal of becoming the World's foremost customer-centric company. Amazon has invested heavily into logistical systems such as their various distribution centers near large cities in the world, advanced expert systems (robotics) for improved efficiency, etc.

Agility: Amazon has the capacity to make quick decisions, irrespective of its size. This enables them to always stay ahead of the game. This is achieved by a couple of built-in systems that ensure promptness and flexibility in their decision-making process. An example of such a system is the "two-pizza rule," which maintains problem-solving teams in a given number and encourages quick decision-making.

The reality is that the best in the world is not even second to Amazon. Currently, the company is making significant investments in new technologies, including Artificial Intelligence, to improve upon this already impressive system which surpasses that of long-standing logistics and shipping companies. This is one competitive edge that might be very hard to replicate.

In a press release dated March $4^{\text {th }}, 2020$, on the Amazon website, there was a detailed breakdown of the milestones they accomplished in their response to the outbreak of the COVID19 through the aid of technology.

Excerpts from this press release can be found in [12].

\section{Exceptional Management}

The CEO of Amazon - Jeff Bezos, is one of the best CEO's in the world today and has won the award for the best CEO in the world a number of times, especially during the early years of Amazon. His ideologies and consistency in pursuing the vision of the company are quite impressive. A review of his speech to the public for the past 23 years has remained progressive and consistent in achieving Amazon's vision. 
Bezos successfully built a Management team and inculcated in them the same enthusiasm and commitment towards achieving the Amazon vision, and he has successfully worked with them all these years to drive the company to its present level of success. This collaboration between a like-minded team of Management towards achieving the same goals and vision is one of the key strategies behind the huge success of the business.

Amazon has a policy of repeatedly testing ideas before streamlining their options to the most effective. The company is not afraid of failing when it comes to investing in the development of a product or service, even if there is a risk of failure surrounding that investment.

Below are some of the highlights of some of the comments of Jeff Bezos, which reflects a picture of the ideologies and commitment of the Management to the goal and vision and Amazon.

"The philosophy of Jeff Bezos is summarized in what he calls "Day 1" and "Day 2". This idea was conceived during the early days of the company. The building they occupied at the time was called "Day 1", and this name was given as a reminder that the company should always maintain "Day 1" mode in its functionality. The concept of "Day 2" is seen as a reversal of the "Day 1" concept, which is usually followed by irrelevance, as a result of a painful and excruciating process of decline and death."

"It remains Day 1." This statement was used to sign off the letter to the shareholders at Amazon by the Founder and CEO, Jeff Bezos. Bezos has promoted the "day 1" mantra for decades, and he says it as a reminder that the company should always operate like a start-up, even though the company has now grown in leaps and bounds.

Excerpts of the CEO COVID-19 speech in 2020 further reflected the strategic Management of the company by maintaining employee welfare and satisfaction; ensuring the safety of their employees. See [13] for further details.

\section{The Next Level in Delivering Customer Experience - Beyond Covid}

From the Jeff Bezos COVID speech in 2020, he further stated a variety of steps in achieving the vision and mission of Amazon. It was clearly presented to the public in the following headings:

1. Meet the Goals of the Paris Agreement on Climate Balance

2. Investment in Electric Vehicles to Achieve Climate Balance

3. Investment in Renewable Energy to Achieve Climate Balance

4. Investment in Packaging Waste Management \& Delivery Network to Achieve Climate Balance

5. Investment in Efficient Data Centers to Achieve Climate Balance

For a full exposition on each of the steps, visit [14] for the foundational mission that powers this new pledge detailed in [15].

\section{Conclusion}

Amazon has become a household name in both books and music industries. It occupies a very high position of advantage amongst other smaller competitors. The company has achieved a remarkable feat in both books and the music market for life. It has expanded its operations as well as its profitability successfully by providing the best E-commerce ever, through proper knowledge of its customers, as well as the longevity of the relationships with its customers by providing a quality customer experience. These three aspects promise to keep Amazon conveniently afloat as well as to retain their dominant position in the industry, regardless of the competition they face.

It would be very tough and discouraging to keep up with Amazon, especially for smaller companies in the industry. They will have to restrategize by offering e-retail services that can compete with what is available in the market. This will be a pre-condition for their success in the industry. They will also need to find a way to ensure customer loyalty for the sake consistency. 
Amazon has succeeded in building a perfect consumer system/platform. Their services offer much more than other platforms, while their charges are a lot more less than others (perhaps the lowest in the industry). They offer the best selection through the combination of a retailbased business and a marketplace kind of business; they offer the best price through the "buybox," initiative, and they ensure the quickest delivery through the FBA initiative offered to their sellers. They operate an effective business strategy known as "flywheel", which means that the more successful Amazon becomes, the more potential for they have to be successful.

The fact that Amazon currently controls about $50 \%$ of the market share in the United States alone and growing shows that their future in the industry is guaranteed. The implication of this is that as Amazon experiences further growth in the industry, this would lead to the growth of Amazon's sellers and vendors. Amazon's tendency to further evolve and grow is based on the fact that they are a platform, a seller and a brand all at once.

As it stands, the only way to effectively compete with Amazon will be to provide equal and better services and value in relation to their most important success metric: pleasing the customer, which currently seems impossible.

\section{References}

[1] Zana Majed Sadq et al (2018), Analyzing the Amazon success strategies, (PDF) Analyzing the Amazon success strategies (researchgate.net), https://www.researchgate.net/publication/328689933 _Analyzing_the_Amazon_success_strategies.

[2] Lydia Depillis and Ivory Sherman (2018), CNN, Amazon's extraordinary evolution - CNN.com, https://edition.cnn.com/interactive/2018/10/business/ amazon-history-timeline/index.html.

[3] Christopher Mcfadden (2021), A Very Brief History of Amazon: The Everything Store, A Very Brief History of Amazon: The Everything Store | IE (interestingengineering.com),

\section{Acknowledgment}

My acknowledgement goes to God Almighty for the opportunity to be alive to undertake a program.

I acknowledge Texila American University for providing the platform. My acknowledgement especially goes to the faculty and all my academic mentors for their assistance and help to complete this project.

I acknowledge my external guide, Dr. Anthony Orji, for making out time to assist in the completion and correctness of the project.

\section{Conflict of Interest}

The author certifies that there is NO affiliation with (or involvement in) any organization or entity that has any financial interest (such as honoria; educational grants; participation in speakers' bureaus; membership, employment, consultancies, stock ownership, or other equity interest; and expert testimony or patent-licensing arrangements), or non-financial interest (such as personal or professional relationships, affiliations, knowledge or beliefs) in the subject matter or the materials discussed in this manuscript.

https://interestingengineering.com/a-very-briefhistory-of-amazon-the-everything-store.

[4] Mark Hall (2021), Amazon.Com, Whole Foods Market | History \& Facts | Britannica

[5] Wikipedia (2021), Amazon (Company), Wikipedia the free Encyclopedia, https://en.wikipedia.org/wiki/Amazon_(company).

[6] Sandeep Krishnamurthy (2002), Case \#1Amazon.Com- A Business History1 To Appear In"E-Commerce Management: Text And Cases," https://paginas.fe.up.pt/ipc/suporte/varios/amazon fi nal.pdf.

[7] Amazon Financial Statements 2005-2021, AMZN, MacroTrends, 
https://www.macrotrends.net/stocks/charts/AMZN/a mazon/financial-statements.

[8] Cormac Hughes (2014), Deloitte, Customercentricity Embedding it into your organisation's DNA,

https://www2.deloitte.com/content/dam/Deloitte/ie/

Documents/Strategy/2014_customer_centricity_delo itte_ireland.pdf.

[9] Kiri Masters,(2019), Forbes, 89\% Of Consumers Are More Likely To Buy Products From Amazon Than Other E-Commerce Sites: Study, https://www.forbes.com/sites/kirimasters/2019/03/2

0/study-89-of-consumers-are-more-likely-to-buyproducts-from-amazon-than-other-e-commerce-

sites/?sh=7c3074024af1.

[10] Jeff Bezos (1997), Amazon, Jeff Bezos’ 1997 Letter to Shareholders,

https://s2.q4cdn.com/299287126/files/doc_financials /annual/Shareholderletter97.pdf.

[11] Jeff Bezos (2020) Jeff Bezos' 2020 Letter to Shareholders,

https://www.sec.gov/Archives/edgar/data/1018724/0 00119312520108427/d902615dex991.htm.

[12] Amazon (2020), Price gouging has no place in our store,

https://www.aboutamazon.com/news/companynews/price-gouging-has-no-place-in-our-stores.

[13] WashingtonAFP (2020), France24, Amazon moves to create lab for employee COVID-19 tests, https://www.france24.com/en/20200410-amazonmoves-to-create-own-lab-for-employee-covid-19tests.

[14] Amazon (2020), Jeff Bezos COVID-19 letter to shareholders, Beyond COVID, https://www.sec.gov/Archives/edgar/data/1018724/0 00119312520108427/d902615dex991.htm.
[15] Amazon (2019). Press release: Amazon Cofounds The Climate Pledge, Setting Goal to Meet the Paris Agreement 10 Years Early, https://press.aboutamazon.com/news-releases/newsrelease-details/amazon-co-founds-climate-pledgesetting-goal-meet-paris.

[16] Anke Moerdyck (2012), How customer centric is your organisation? InSites, https://insitesconsulting.com/blog/how-customer-centric-is-yourorganisation/.

[17] Andy Lane (2019), What is technology? OpenLearn - Open University, https://www.open.edu/openlearn/science-mathstechnology/engineering-andtechnology/technology/what-technology.

[18] Bahadir Kandemirli (2018), Amazon.com's Digital Strategies Amazon.Com Case Study, https://www.researchgate.net/publication/326132044 _amazoncom's_digital_strategies_amazoncom_case _study.

[19] Brian Roemmele (2017), Forbes, What Is Jeff Bezos's "Day 1" Philosophy? https://www.forbes.com/sites/quora/2017/04/21/wha t-is-jeff-bezos-day-1philosophy/?sh=ee51a8710523.

[20] Grace Baldwin (2020), Amazon, The Strategies Behind Amazon's Success, https://www.omniaretail.com/blog/the-strategiesbehind-amazonssuccess\#: :text=Amazon $\% 20$ sales $\% 20$ strategies,off er $\% 20 a \% 20$ consistently $\% 20$ great $\% 20$ experience. $\& \mathrm{t}$ ext $=$ Much $\% 201$ ike $\% 20$ Amazon $\% 20$ considers $\% 20 \mathrm{cu}$ stomer,so $\% 20$ to $\% 20$ do $\% 20$ its $\% 20$ Sellers. 


\title{
Gender and Perceived Usefulness of e-HRM Technologies. A Case of the Bankers' Experience in Tanzania
}

\author{
Judith Namabira*, Hezbon Tenison Mtawa \\ Institute of Rural Development Planning, Dodoma, Tanzania
}

\begin{abstract}
This study investigates the impact of gender differences on the perceived usefulness of e-HRM technologies, using 158 observations from a survey conducted in one of the commercial banks in Tanzania. The descriptive statistics show that the e-HRM technologies in the bank have not been perceived as useful. With the T-Test, it has been found out that men perceive the e-HRM technologies more useful compared to women. The paper urges the promoters of e-HRM technologies in organizations to better understand the ways in which the use of such technologies can be enhanced to their employees, particularly women. The study proposes further research on e-HRM and gender, particularly on the impact of e-HRM technologies on spending, time saving, and errors.
\end{abstract}

Keywords: Adoption; Gender; Perceived usefulness; Perceived ease to use; e-HRM.

\section{Introduction}

Electronic, human resource management (eHRM) is a way of implementing human resources strategies, policies, and practices in organizations through a conscious and directed support of web-based technology channels, computer hardware and software, and electronic networking resources [1-4]. The intention behind e-HRM is to facilitate the function of human resource management with a composite of technologies and practices.

The adoption of e-HRM technologies, as is with other technologies, is greatly influenced by the factors of perceived ease of use and perceived usefulness [5-7]. While the perceived ease of use has to do with how one believes that the use of technology will be free from effort [5] or requires minimum effort [8], the perceived usefulness has to do with the degree to which a user of technology believes that using the technology is of use [5]. The perceived usefulness and ease of use are linked because, as Barhoumi [9] points out, the perceived ease of use can increase perceived usefulness and increase comprehension about technology adoption. Besides the perceived usefulness and the ease of use is also the perceived social pressure coming from individuals whose beliefs and opinions are important, including peers and people who are in social networks [10].

The concept of perceived usefulness was first defined by Davis [5] in the context of ICT as the degree to which a person believes that using a particular ICT would enhance his or her job performance. In this sense, perceived usefulness is linked to job performance and has been widely used so [8, 11-14]. It is in this same sense of performance that Lwoga [15] views perceived usefulness in the education realm, whereby perceived usefulness is the degree to which students believe that using technologies will improve their learning performances. Besides performance, perceived usefulness is linked to improving work: perceived usefulness as an individual belief that technology will make their work better [16].

Some research on gender and e-HRM adoption has been done. There has been some research on the key factors to influence the adoption of e-HRM technologies, among which 
gender is linked with the adoption attitudes [17]. Gender is also an area in which the findings of the Technological Acceptance Model (TAM) have been extended [18]. Sometimes it is surprising that gender is absent in studies where one would expect it to be. For instance, in a research about the factors that influence continuous intention to use E-HRM, using the Technology Acceptance Model and Cognitive Model for identifying significantly impacted areas of continuous intention to use E-HRM in a highly dynamic environment, one would expect to see gender relations; this is not the case [19]. Another example is a study by e-HRM experts about what transpired in the four decades of research in e-HRM [20]. These authors point out that the three factors that still seem to affect the adoption of e-HRM technologies are technology, the organization, and people; there is no mention of gender as an issue.

This study deals with the influence of gender on the perceived usefulness of e-technology. In a particular way, the study establishes how gender impacts on the perceived usefulness of eHRM technologies. The question for this paper is: are there significant differences between men and women bank employees' perceived usefulness in adopting e-HRM technologies? This question is premised on the finding by [21] that the demographic factors affect the individual's adoption of technological innovation and the Technology Acceptance Model (TAM), which postulates that the behavioral intention to adopt technology is a function of its perceived usefulness [22]. The study examines if a specific demographic factor, gender, affects the bankers' perceived usefulness of the e-HRM technologies at their workplace. The perceived usefulness is measured in terms of individual cost reduction, time-saving, and error reducing.
From a gender perspective, this study addresses the concern that studies of women and technology are neglected [23]. In a particular way, it adds on the inexistent literature regarding gender and the adoption of e-HRM technologies. The finding that there exists an e-HRM adoption gender technological divide is bound to inform the public policy goal of a globally equitable information society [24], particularly at workplaces; e-technologies are becoming increasingly vital to the management of human resources in public and private organizations, and hence the need to address the e-HRM technologies' adoption divide in gender, as well.

\section{Methodological Underpinnings}

The data being used in this paper derives from a quantitative survey conducted in 2019 in the three cities of Tanzania, one being the biggest, another one being the second biggest, and the last one being the fastest growing; the respondents were randomly selected from the branch categories of the mega, big, medium, and small branches. The bankers were targeted as the users of the e-HRM systems.

A questionnaire was designed in Google Forms and sent to the respondents by sharing a link via their WhatsApp accounts. Before the link was shared, a text was sent explaining the purpose of the study, assuring them of confidentiality of their responses and anonymity, and requesting their consent in order to participate in the study. Out of the 198-shared links, 162 were returned fully filled and submitted, yielding a response rate of $82 \%$. The profile of the respondents, as presented in Table 1 shows that most of the respondents had their Bachelor's degree (65\%), came from big branches (48\%), were adults of ages between 38 and $60(46 \%)$, were bankers by position (69\%), were experienced (83\%), and were male (62\%). 
Table 1. Respondents Profile

\begin{tabular}{|l|l|l|l|}
\hline Respondents & Gale & Frequency & Percent \\
\hline \multirow{3}{*}{ Agender } & Female & 97 & 61 \\
\hline \multirow{5}{*}{ Educational Level } & Below 35 years & 61 & 39 \\
\cline { 2 - 4 } & Above 35 years & 84 & 53 \\
\cline { 2 - 4 } & Secondary education & 74 & 47 \\
\cline { 2 - 4 } & Bachelor's degree & 8 & 5 \\
\cline { 2 - 4 } & Master's degree & 103 & 65 \\
\hline \multirow{5}{*}{ Pranch Size } & Small & 47 & 30 \\
\cline { 2 - 4 } & Medium & 31 & 19 \\
\cline { 2 - 4 } & Big & 54 & 33 \\
\hline \multirow{5}{*}{ Experience } & Support staff & 77 & 48 \\
\cline { 2 - 4 } & Banker & 8 & 5 \\
\cline { 2 - 4 } & Manager in bank & 112 & 69 \\
\cline { 2 - 4 } & Little experience (below 1 year) & 42 & 29 \\
\cline { 2 - 4 } & Moderate experience (between 1 \& 4 years) & 134 & 83 \\
\cline { 2 - 4 } & Very experienced (above 5 years) & 8 & 5 \\
\hline
\end{tabular}

Source: Researcher Survey (2019)

The collected data was about establishing the levels of agreement with the factors of adoption of e-HRM technologies and practices in the bank on a 5-point Likert scale whereby "1" stood for strongly disagree and " 5 " for strongly agree. The variables of interest from this data are enshrined in the following statements: (1) e-HRM technologies reduce my costs; (2) e-HRM technologies save my time; and (3) e-HRM technologies reduce my errors.

These statements were to be assessed by the respondents bearing in mind the e-HRM systems that have been used in the bank since the introduction of e-HRM technologies. The bank has employed three e-HRM systems since 2007 in order to dispense human resources services to the bank employees. Before the introduction of any e-HRM technologies, all HR activities were done manually. Tasks, such as leave applications, promotions, and transfers, to mention but a few, were done manually. With the introduction of e-HRM technologies, tasks began being automated. The first e-HRM system (E-TECH-1) was acquired in 2007 and was used till 2010; it was a stand-alone system on only one computer of the HR manager for the purposes of salary management. Another e-HRM system was adopted in 2010, and it is still in use till today; this system has several modules, namely: Payroll, Transition, Leave, and Loan request. Mid 2019, another e-HRM system was introduced, with more modules, namely: Performance and goals, Succession and development, Recruitment, and selection, Learning and development (learning management system), Compensation and Payroll, Employee Central (foundation for all the activities), and On-Boarding and Off-boarding.

The study tests the null hypothesis that gender does not matter in the perception of the usefulness of the e-HRM technologies; the alternative hypothesis is that gender matters in the perception of the usefulness of the e-HRM technologies. In describing the three variables that measure perceived usefulness (cheapness, time saving, and error reducing), an assessment is made about whether the factor is less useful or useful. Both the "strongly agree" and "agree" are assessed as "useful" (any mean score from 3.6 and above). "Completely disagree", "disagree", and "not sure" are assessed as less useful (any mean score below 3.6). The results are tabulated in Table 2. An independent-samples T-Test is used to determine whether the mean of the levels 
of perception of the usefulness of the e-HRM technologies (dependent variable) is the same or not for the two independent groups of males and females. The independent t-test determines whether the mean difference between the males and females is statistically significantly different to zero. Specifically, this is to test whether the perception of the usefulness of the e-HRM technologies changes according to gender. With a p-value of less than 0.05 , the null hypothesis is rejected, and the alternative hypothesis is accepted.

\section{Results}

\section{Assessing the Perceived Needs}

Table 2 summarizes the results regarding the assessment of the perceived usefulness.

Table 2. Assessment of the Perceived Usefulness

\begin{tabular}{|l|l|l|l|}
\hline Variable & Observation & Mean & Assessment \\
\hline e-HRM technologies reduce my costs & 158 & 3.322785 & Less useful \\
\hline e-HRM technologies save my time & 158 & 4.050633 & Useful \\
\hline e-HRM technologies reduce my errors & 158 & 2.841772 & Less useful \\
\hline General assessment & & $\mathbf{3 . 4 0 5 0 6 3 3}$ & Less useful \\
\hline
\end{tabular}

Source: Researcher Survey (2019)

The results in Table 2 show that the general perception assessment about the perceived usefulness of e-HRM technologies in the bank is that they are less useful (mean score <3.6). It is only the factor of e-HRM technologies that seems to be useful (mean score $>3.6$ ).

\subsection{Influence of gender on perceived usefulness}

Table 3 summarizes the results regarding the T-test performed on gender and the perceived usefulness of e-HRM technologies in the bank.

Table 3. Assessment of the Perceived Usefulness

\begin{tabular}{|l|l|l|l|}
\hline Factor & Gender & Means & P-value \\
\hline Reducing costs & Female & 2.540984 & \multirow{2}{*}{0.0000} \\
\cline { 2 - 3 } & Male & 3.814433 & \\
\hline \multirow{3}{*}{ Saving time } & Female & 3.803279 & \multirow{2}{*}{0.0095} \\
\cline { 2 - 3 } & Male & 4.206186 & \\
\hline \multirow{3}{*}{ Reducing errors } & Female & 2.344262 & \multirow{2}{*}{0.0000} \\
\cline { 2 - 3 } & Male & 3.154639 & \\
\hline
\end{tabular}

Source: Researcher Survey (2019)

The results in Table 3 show that gender has an impact on the perception of the usefulness of the e-HRM technologies. With the p-value $<0.05$, the null hypothesis that gender does not matter in the perception of the usefulness of the e-HRM technologies is rejected, and the alternative hypothesis that gender matters in the perception of the usefulness of the e-HRM technologies is accepted. In all the areas of perceived usefulness observed, the mean scores of the males are always high, compared to those of women: on reducing individual costs, for men
$3.8814433>2.540984$ for women; on saving individual time, for men 4.206186 $>3.803279$ for women; on individual reducing errors, for men $3.154639>2.344262$ for women. These results imply that men, in general, perceive the usefulness of the e-HRM technologies more than women.

\section{Discussion}

The findings that male perceived more useful e-HRM technologies compared to women is consistent with some literature. For instance, in 
their extensive literature review regarding gender differences in technology usage, Goswami and Dutta [25] find out that in some contexts, such as the use of computers, email services, electronic data management systems, elearning applications, online stock trading, gender acts as an influencing factor as men are found to be more technologically adept compared to women and that females faced technical challenges and risk in using technology. Similarly, Venkatesh and Morris [26] found out that in the process of a new technology being introduced in school, male teachers gave more consideration to perceived usefulness than female teachers for making decisions regarding the use of new technology.

However, still, Goswami and Dutta [19] in their literature review, found out that the gender difference perception of usefulness is not being observed with respect to the use of social media, mobile or internet banking, e-commerce. Similarly, when Debrand and Johnson [27] examined gender differences concerning the perceived usefulness of e-mail and instant messaging for social communications, they found out that women perceived e-mail and instant messaging to be more useful, and they spent more time communicating with others via e-mail and instant messaging than men.

Hence, there are mixed results with respect to the influence of gender on the perceived usefulness of technologies, a situation that, in line with [28], suggests that the gender differences, or lack thereof, related to the perceived usefulness of technology may depend on the context in which the relevant technology is used, particularly the gender configurations of that community or organization.

\section{Conclusion}

From the gender perspective, the study affirms the gender gap in the perception of the usefulness of the e-HRM technologies. This implies that the women have not yet found eHRM technologies useful to them, compared to men, and consequently, the likelihood of poor adoption of such technologies. While it is true that technologies are gendered, it is also true that technologies shape gender relations. The promoters of e-HRM technologies in organizations need to better understand the way in which such technologies enhance the perception of their usefulness by their employees, particularly the women, who need to see these technologies more empowering than promoting or keeping the status quo of gender relations and their impact on lives. For this matter, further research on e-HRM and gender are needed, particularly on the impact of e-HRM technologies on spending, time-saving, and errors.

\section{Acknowledgements}

We would like to acknowledge the support of our employee, the Institute of Rural Development Planning, for its moral support and time in order to write this paper. We thank our colleagues from the Institute of Rural Development Planning (IRDP), Dodoma, who provided insights and expertise that greatly assisted the writing of this paper, although they may not agree with all of the interpretations and conclusions of this paper. We thank Prof. Adalbertus Kamanzi for his assistance with methodological comments that greatly improved this work.

\section{Conflict of Interest}

We, the authors, Judith Namabira and Hezbon Tenison Mtawa, hereby declare that the disclosed information is correct and that no other situation of real, potential, or apparent conflict of interest is known to us. We undertake to inform you of any change in these circumstances if any issue arises. 


\section{References}

[1] Ruel, H. J. M., Bondarouk, T., \& Looise, J. C., 2004, E-HRM: Innovation or irritation. An explorative empirical study in five large companies on web-based HRM, Management revue, 15(3), 364380 ,

http://www.management-

revue.org/papers/mrev_3_04_Ruel_Bondarouk_Looi se.pdf.

[2] Gopal, R., \& Shilpa, V., 2011, The implications of implementing electronic-human resource management (e-HRM) systems in companies, Journal of Information Systems and Communication, 2 (1), 10-29.

[3] Marler, J.H., \& Parry, E., 2016, Human resource management, strategic involvement and e-HRM technology, International Journal of Human Resource Management, 27 (19), 2233-2253, https://doi.org/10.1080/09585192.2015.1091980.

[4] Bondarouk, T., Ruël, H., \& van der Heijden, B., 2009, e-HRM effectiveness in a public sector organization: A multi-stakeholder perspective, International Journal of Human Resource Management, $20 \quad$ (3), 578-590, https://doi.org/10.1080/09585190802707359.

[5] Davis, F.D., 1989, Perceived usefulness, perceived ease of use, and user acceptance of information technology, MIS Quarterly, 13 (3), 319340.

[6] Agarwal, R. \& Prasad, J., 1998, The antecedents and consequents of user perceptions in information technology adoption, Decision Support Systems, 22 (1), 15-29.

[7] Rogers, E.M., 2003, Diffusion of Innovations, $5^{\text {th }}$ ed. New York: The Free Press.

[8] Huang, J., \& Martin-Taylor, M., 2012, Turnaround user acceptance in the context of HR selfservice technology adoption: an action research approach, The International Journal of Human Resource Management, 24 (3), 621-642.

[9] Barhoumi, C., 2016, User acceptance of the einformation service as information resource A new extension of the technology acceptance model, New Library World, 117 (9/10), 1-18.
[10] Igbaria, M., Parasuraman, S., \& Baroudi, J., 1996, A motivational model of microcomputer usage, Journal of Management Information Systems, 13 (1), 127-143.

[11] Adams, D.A., Nelson, R.R., \& Todd, P.A., 1992, Perceived Usefulness, Ease of Use, and Usage of Information Technology - A Replication, MIS Quarterly, 16 (2), 227-247.

[12] Taylor, S., \& Todd, P.A., 1995, Understanding Information Technology Usage - A Test of Competing Models, Information Systems Research, 6 (2), 144-176.

[13] Venkatesh, V., \& Davis, F.D, 2000, A theoretical extension of the Technology Acceptance Model: 21 / 21 Four longitudinal field studies, Management Science, 46 (2), 186-204.

[14] Venkatesh, V., Morris, M.G., Davis, G.B., \& Davis, F.D., 2003, User acceptance of information technology: Toward a unified view, MIS Quarterly, 27 (3), 425-478.

[15]Lwoga, T., 2012, Making Web 2.0 Technologies work for higher learning institutions in Africa. Campus, Wide Information Systems, 29 (2), 90-107. [16] Usoro, E. \& Majewski, G., 2014, A Model of Acceptance of Web 2.0 in Learning in Higher Education: a case study of two cultures, E-Learning and Digital Media, 11 (6), www.wwwords.co.uk/ELEA.

[17] Myllymäki, D., 2021, Beyond the 'e-' in e-HRM: integrating a socio-material perspective, The International Journal of Human Resource Management, 32:12, 2563-2591, DOI: 10.1080/09585192.2021.1913624.

[18] Heikkila, J. 2013, Perspectives on e-HRM in the Multinational Setting, Vaasan Yliopisto.

[19] Noernam, T., Erlando, A., \& Riyanto, F.D., 2021, Factors Determining Intention to Continue Using E-HRM, Journal of Asian Finance, Economics, and Business, 8 (2), 1079-1089.

[20] Bondarouk, T., Parry, \& Furtmueller, E., 2017, Electronic HRM: four decades of research on adoption and consequences, The International Journal of Human Resource Management, 28 (1), 98131, DOI:

https://doi.org/10.1080/09585192.2016.1245672. 
[21]Quazi, A. \& Talukder, M., 2011, Demographic determinants of employees' perception and adoption of technological innovation, Journal of Computer Information Systems, 51 (3), 38-46.

[22] Davis, F., Bagozzi, R., \& Warshaw, P., 1989, User acceptance of computer technology: A comparison of two theoretical models, Management Science, 35 (8), 982-1003.

[23] Kuschel, K. \& Lepely, M., 2016, Copreneurial women in start-ups, Academia Revista Latinoamericana de Administración, 29 (2), 181 197. http://dx.doi.org/10.1108/ARLA-08-2015-0231. [24] United Nations, 2014, 'Empowering women entrepreneurs through information and communications technologies: a practical guide', UN Conference on Trade and Development, UNCTAD Current Studies on Science, Technology and Innovation, Vol. 9.

[25] Goswami, A., Dutta, S., 2016, Gender Differences in Technology Usage-A Literature
Review, Open Journal of Business and Management, 4. 51-59. http://www.scirp.org/journal/ojbm; http://dx.doi.org/10.4236/ojbm.2016.41006.

[26] Venkatesh, V., \& Morris, M. G., 2000, Why don't men ever stop to ask for directions? Gender, social influence, and their role in technology acceptance and usage behavior, MIS Quarterly, 24, 115-139. https://doi.org/10.2307/3250981

[27] Debrand, C.C., \& Johnson, J. J., 2008, Gender differences in email and instant messaging: A study of undergraduate business information systems students, Journal of Computer Information Systems, 48 (3), 20-30.

[28]Teo, T., Fan, X., \& Du. J., 2015, Technology acceptance among pre-service teachers: Does gender matter? Australasian Journal of Educational Technology, 31 (3), 235-251. 


\title{
The Strategic Impact of Total Quality Management on Customer Satisfaction. A Case Study of Colour Fiesta Nigeria Limited
}

\author{
Gladys Harold-Juwah \\ Ph.D. in Management, Texila American University, Guyana
}

\begin{abstract}
The importance of Total Quality Management in businesses today cannot be over emphasised because the over-increasing needs of the customers and the right to quality has taken a long way in ensuring that organisational strategic objectives are set to meet this demand. Customer satisfaction is a major concern of most organisations, this has led to corporate strategies being considered as important in total quality management. This study examines the strategic impact of total quality management on customer satisfaction in Colour Fiesta Nigeria Limited which is involved in printing and publishing. The major aim of this study is to evaluate the relationship between senior management commitment in total quality management and the effect it will have on customer satisfaction. It is believed that customers are unsatisfied due to the failure of total quality management hence the active involvement of the top management. Based on the findings, it was revealed that the management of Colour Fiesta is more concerned of continuous quality improvement and customer focus philosophy than benchmarking, employee training, etc. There was also an inconsistency in integrating total quality management with the strategic planning process. In conclusion, the result shows that total quality management plays a vital role in the strategic implementation of customer satisfaction.
\end{abstract}

Keywords: Affinity and Ishikawa diagram, Benchmarking and QC Circle, ISO 9001 Standard, Process management, Quality function deployment, Total Quality.

\section{Introduction}

The basic element in this study are corporate strategies, total quality management and customer satisfaction. There is a need to understand the impact of the relationship between them and the effect on consumer behaviour.

Several attempts have been made by different researchers to study the concept of total quality management but ended up opening more gaps to be filled. Every Organisation inclusive of Colour Fiesta Nigeria Limited's aim is to make strategic decisions that will enable the company to earn profit through satisfying their customers.
Colour Fiesta Nigeria Limited is a printing and publishing organisation with a business operation in Nigeria. It has a staff strength of 200 (50 top management and 150 operational staff) and one of its main objectives is to be a leading printing firm that provides customers with top-notch quality in every first-time engagement with the company. It believes in continuous improvement through customer feedback, promoting employee and top management involvement, encouraging teamwork, flexible workforce, and developing strategies to improve quality and responsiveness in all sectors of the organization thereby achieving set goals and objectives, organizational sustainability, and returns on investment. 
It is a known belief that customers are regarded as king in the market and when they believe in a brand and are satisfied with the product and services offered by the organization, they become a good advocate and attract other prospective customers to the brand. Total Quality Management (TQM) is a continuous management approach that ensures the long-term goals and objectives of the organization are achieved through customer satisfaction. Every employee of the organization must be involved in improving the TQM processes, this will ensure that customer gets superior products and services when they are satisfied, which leads to customer loyalty, higher productivity that increases revenue, and reduction in waste.

The main aim of this research is to conduct a descriptive research design to verify the strategic impact of total quality management on customer satisfaction and this can be achieved by placing corporate strategy and total quality management in the context of consumer behaviour.

The study will develop an understanding of the relationship amongst the three key elements of this research as opposed to testing other existing theory. A literature review will be given as well as a description of the research methodology and the data collection method. The data will be reviewed and analysed on the reported relationship among organisational strategies, total quality management and customer satisfaction. Finally, the key findings and conclusion will be based on the analysis given.

\section{Objective of the Study}

It is believed that studying the impact of Total Quality Management on customer satisfaction is based on four focus areas which include, Customer Focus, process focus, innovation focus and environmental focus, these focuses will enhance organizational performance. In this study, we are focusing on a single focus area - customer focus. The major objective is to identify the strategic impact of the relationship between TQM and performance through customer satisfaction.

\section{Literature Review}

\section{Total Quality Management Concept}

Total Quality Management (TQM) is a management approach which focuses on quality, processes and people with major enhances on improving organisational performance and satisfying customers [1]. Quality is no longer considered as the duty of the quality assurance team but everyone's job in the organisation. Quality improvement has become a way of life as well as a philosophy. [2] supports this view that company-wide philosophy requires all employees at all levels to focus on improving each business process of the organisation. In this vein, the more processes are improved in every department in Colour Fiesta, the easier it is to deliver higher quality products and services to customers.

TQM is applicable to every organisation irrespective of size and motives. The emphasis on quality in all facets of an organisation like Colour Fiesta will assist to reduce waste and rework and increase production efficiency. TQM improves the relationship between existing process and customer satisfaction by integrating management systems. It also allows for the implementation and monitoring of other tools like ISO and Ishikawa diagram, values (continuous improvement, customer, and process focus), and methodologies (benchmarking, QC Circles), all these varies from one organisation to the other. 


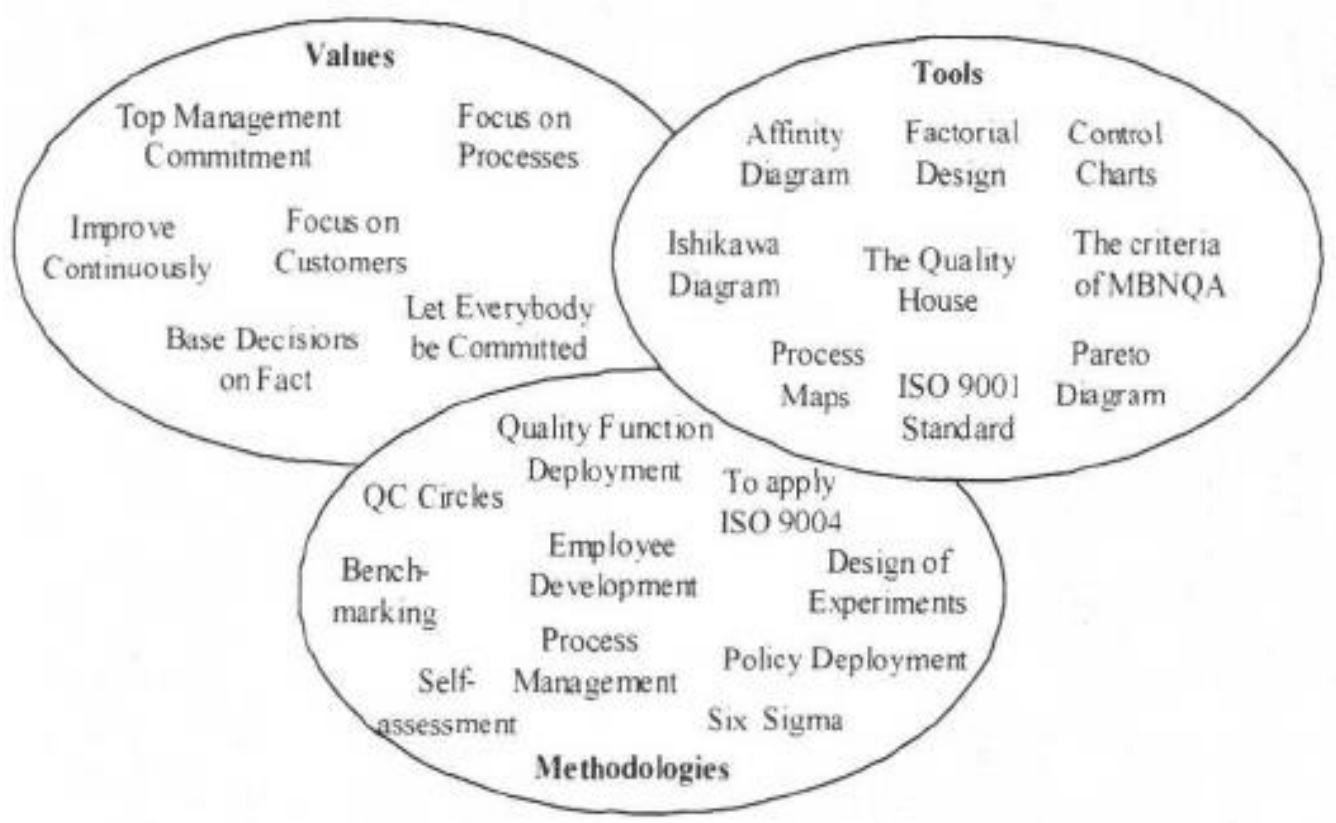

Figure 1. TQM as a Management System of Values, Tools and Methodologies

Source: Hellsten, U. and Klefsjo, B [3]

\section{Customer Satisfaction}

Customer satisfaction measures how well an organisation's product and services meet or surpasses the customer's expectation. When a customer is satisfied, he/she contributes to the long-term relationship development and construction of loyalty. This loyalty makes the organisation to have a competitive edge over other organisation, thereby increasing return on investment. [4] opined that Loyalty is dependent on the degree of customer satisfaction and trust.

When a company has loyal customers, it will gain positive word-of-mouth marketing which is highly effective and free. It is observed that customer satisfaction ratings have a powerful effect on an organisation most especially in printing and publishing, so employees focus on fulfilling customer's expectations. When there is a dip in these ratings, it shows there is a problem that can affect service and profitability. More so, it is very important for companies to set strategies that can effectively manage customer satisfaction through the inclusion of TQM.

\section{Benefit of Total Quality Management}

There are numerous benefits and goals of total quality, it helps in the reduction of total quality costs through prevention of defective products than at the expense of quality failure cost. [5] stated that total quality lowers costs, gives higher revenue, satisfies customers, and empowers employees.

Secondly, TQM assists in increasing productivity as a result of cost reduction, highend technology and resources, infrastructure, and competent employees. In addition, TQM enables organisation to conduct research on prevailing challenges and bring in innovative marketing decisions which attract customers. TQM focuses on customer satisfaction because it creates a pathway to understand the needs of the customers which enables the organization to deliver specific products and services. [6] opined that customers' needs should be integrated in the design and development of products, in so doing, customers will be treated as an equal partner in the life cycle of the product. 
Furthermore, TQM brings about changes in the behavioural pattern of the workers by promoting good work culture, teamwork, selfdevelopment, and employee engagement which enables better organizational performance. It is obvious that TQM brings both tangible (high product quality, increased profitability, and market share) and intangible returns (teamwork, better communication, goodwill, and employee engagement). It also expects employees to undergo substantial training, participate in quality improvement and organizational wide involvement. Everyone in the organisational hierarchy must partake and strongly support the success of the TQM program.

\section{TQM and Organizational Performance and Sustainability}

Total Quality Management should be made more prominent within the purview of corporate strategic processes. Senior management should be involved in the creation of corporate image and driving campaign for new programme change and continuous improvement.

The growing awareness of TQM ensures that business drivers are linked with organisational issues such as strategic quality planning, leadership, people, and process management.

TQM is seen as a management system that includes a component of sustainable development. It must be used to establish objectives and strategies that will aid in meeting stakeholder's requirements.

It should monitor the external environment and the organisational capabilities as well as provide the feedback needed for continuous improvement, innovation, and identification of the desired organisational changes. TQM implementation brings a positive impact on the quality of the product and services, thereafter, having a better effect on the overall performance of the organisation. [7] stated that employee commitment, customer focus, shared vision does not necessarily contribute to a higher quality outcome. On the contrarily, I believe that the importance of total quality management in increasing organisational performance should not be ignored because its benefit outweighs its failure.

\section{Obstacles affecting effective TQM}

There are different obstacles and barriers affecting the successful of total quality management and this includes lack of leader for quality, lack of planning, inadequate human resources, and lack of customer focus.

The main reason TQM fails is due to half measures in implementing TQM. Some organisations are not willing to commence the total cultural transformation, this is because some senior managements do not know what cultural change is and the best way to approach the transformation. In continuation, top management's failure to move employees towards a total quality concept leads to one of the obstacles against the success of TQM. Total quality management fails due to improper implementation and not the TQM theories and methods [8].

The management's lack of capacity to identify and close up the gaps between TQM and the actual practise, that is, the inquiry process, analysis, and embedded actions are the major causes of TQM implementation failure. Lack of senior management commitment is an important obstacle that should be avoided, so training of top management should be carried out to enable them to understand the benefits and philosophy of TQM and the best way to implement it.

\section{Research Methodology}

\section{Data Collection and Sample}

The purpose of this study is to investigate the strategic impact of Total Quality Management on customer satisfaction in Colour Fiesta Nigeria Limited. A descriptive research design and inferential statistical techniques were used for this study. The description research design determines the relationship between the variables and identifies the effect of one 
variable on the others. Primary and secondary data sources were used for analysing this study. The primary data was obtained through the use of a questionnaire while the secondary data were through related literature collected from published and unpublished sources.

Two different questionnaires were administered, one was applied to customers and the second questionnaire was given to the employees of the printing and publishing company. The respondents were asked to use the 5 points Likert-scale (from 1 being poor to 5 very good) to indicate their level of agreement.

A total of 100 questionnaires were administered to customers and employees of Colour Fiesta Nigeria Limited. Eighty of the questionnaires were successfully retrieved which constitutes $80 \%$ of the response rate of which $40(50 \%)$ were filled by females and 40 $(50 \%)$ by males. The sample age group is between 17 and 65 years old with an average age of 32 years.

\section{Test of Reliability}

The questionnaire was subjected to a reliability test using The Cronbach Alpha approach and obtained a reliability co-efficient of 0.774 . It can be said that a reliability of 0.7 and above on a significant sample is considered a good instrument [9] hence the obtained value is internally acceptable as consistent among the variables.

\section{Data Presentation and Analysis}

The collated data was analysed using descriptive and inferential statistical techniques. The second hypothesis was analysed using descriptive statistics to describe the demographic characteristics of the respondents while the first hypothesis at 0.05 alpha level used the simple regression analysis. The missing values were checked before the statistical analysis was carried out. There are different number of items in each domain hence a normalisation procedure was applied. The sum of raw scores in each domain was divided by the number of items in the domain using the Likert Scale of $0-5$ scales for each domain for normalisation.

The description statistic which was used to obtain the primary source of data for demographics is shown in the table below.

Table 1. Respondents' Response to the Questionnaire

\begin{tabular}{|l|l|l|}
\hline Criteria & Frequency & Percentage Response \\
\hline Gender & 40 & 50 \\
\hline Male & 40 & 50 \\
\hline Female & \multicolumn{2}{l|}{} \\
\hline Educational qualification & \multicolumn{2}{l|}{} \\
\hline Senior Secondary certificate & 12 & 15 \\
\hline National Diploma & 22 & 27.5 \\
\hline Degree & 30 & 37.5 \\
\hline Higher qualification & 16 & 20 \\
\hline Age & \multicolumn{2}{|l}{} \\
\hline $20-25$ & 11 & 13.8 \\
\hline $25-35$ years & 33 & 41.2 \\
\hline 35 years and above & 36 & 45 \\
\hline Level of Patronage & \multicolumn{2}{|l}{} \\
\hline Low & 15 & 18.8 \\
\hline Moderate & 47 & 58.8 \\
\hline High & 18 & 22.5 \\
\hline
\end{tabular}


Table 2. Summarised Multiple Regression Analysis of the Result of the Strategic Relationship between Total Quality Management and Customer Satisfaction

\begin{tabular}{|l|l|l|}
\hline Variable & Co-efficient & Probability \\
\hline Employee's attitude & 0.23 & 0.07 \\
\hline Focus on material resources & -0.06 & 0.63 \\
\hline Leadership and management commitment & 1.40 & 0.17 \\
\hline Continuous improvement & 0.38 & $0.00 *$ \\
\hline Effective communication & -0.09 & 0.50 \\
\hline Adequate knowledge & 0.00 & 0.99 \\
\hline Prompt quality delivery & 0.35 & $0.00 *$ \\
\hline
\end{tabular}

Table 3. Regression Analysis of the Data

\begin{tabular}{|l|l|}
\hline$R$ & 0.59 \\
\hline$R^{2}$ & 0.35 \\
\hline Durbin-Watson & 1.69 \\
\hline$F$ - statistics & 4.10 \\
\hline
\end{tabular}

Table 4. Ranking and Mean Analysis of External Factors that Impact TQM as Stated by the Respondents

\begin{tabular}{|l|l|l|}
\hline External Factors & Means & Rank \\
\hline Lack of management commitment & 3.59 & $1^{\text {st }}$ \\
\hline Poor employees training & 3.56 & $2^{\text {nd }}$ \\
\hline Poor communication & 3.55 & $3^{\text {rd }}$ \\
\hline Lack of employee feedback & 3.17 & $4^{\text {th }}$ \\
\hline Bureaucratic approach & 2.65 & $5^{\text {th }}$ \\
\hline
\end{tabular}

\section{Result and Discussion}

As shown in Table 1, the questionnaire was distributed equally with $50 \%$ of respondents from male and female respectively. In addition, it shows the respondents understood the content of the questionnaire as $85 \%$ of the respondents has above the senior school certificate. $86.2 \%$ of the respondent are adults since they are above 18 years old hence are mature enough to know what quality entails. Furthermore, in the level of patronage, $81.3 \%$ show that they have a middle to a high level of patronage of the printing and publishing company, hence having a good knowledge of the required response to provide.

From the regression analysis shown in Table 3 , the obtained result showed that $35 \%$ of the variation in the dependent variables is seen in the explanatory variable. The probability of rejecting the F- statistics (4.10) was seen to be
0.00 which shows there is a significant relationship between the independent variable and the dependent variable. 1.69 which is the Durbin Watson statistic is within the acceptable range, it shows that auto serial correction is not present. The variables that are most visible in the printing and publishing company's survey are continuous improvement and prompt service delivery which have a positive coefficient of 0.38 and 0.35 respectively.

There is a positive but insignificant relationship between total quality management and all the independent variables in the regression analysis. This indicates that other factors have an impact on customer satisfaction apart from the quality provided by the organisation. According to [10] the percentage of satisfied migrated customers is even higher. [11] also stipulated that there is no significant relationship between transaction satisfaction appraisal and the length of the company- 
customer relationship. [12] disagrees with this assertion by stating that customer satisfaction and customer loyalty are closely linked. In my opinion, customer satisfaction is not only dependent on total quality practices but also on other factors like closeness of the organisation, alternatives availability, external influences, and social status.

As shown in Table 4, it indicates that there is a lack of management commitment and appreciation of the strategic impact of TQM on customer satisfaction. This is evident in Colour Fiesta Nigeria Limited. When the further probe was done in seeing TQM in a strategic context, most of the response was "TQM comes like a flash and there is a commitment to quality and things are continuously improving". This comment does not provide a TQM as a strategic driver in the organization, hence in agreement with the respondents, the organization do not see TQM as a key strategic driver.

The other factor that affected TQM is lack of proper training of the employees on TQM concept and its invariable impact on customer satisfaction. The organization should provide useful training for the existing staff and employ more skilled workers to gain more satisfied customers.

Furthermore, poor communication has a negative impact in the strategic decision of the organization. For the success of TQM, all members, suppliers, and customers must communicate effectively because communication acts as a vital link in the element of TQM.

In addition, there was a notable lack of employees input and feedback to the corporate level. The employees are allowed to provide their input in the decision-making process on already established goals and targets and this is placed upon each unit to be achieved operationally. The organization should improve its feedback collection system.

Lastly, Colour Fiesta has a top-downbureaucratic and rigid strategic form. All the corporate strategies are created by the CEO and the senior management. There is little evidence of dynamic structure that can create a fastmoving strategic process that can ensure customers are satisfied and lead to customer loyalty.

\section{Conclusion}

This research attempted to answer the strategic impact of implementing TQM and its effect on customer satisfaction. The description and inferential statistics were used to determine a picture of TQM, its influence on strategies, and customer satisfaction. The data revealed a series of key issues. First, the inconsistency in TQM in the organisation was researched hence there is a need to integrate TQM and strategy with the company, so necessary progress can be made in achieving customer satisfaction.

Secondly, TQM should be made the key driver during the strategic decision-making process because in the organization there is little evidence of intertwine of TQM and corporate strategy. More so, employee involvement, feedback mechanism, and customer impact should be directly attributed to TQM, so it can have little impact on strategic decision making.

Furthermore, the study analysed relevant data on TQM and customer satisfaction which revealed that TQM has a relative low impact on the operations of Colour Fiesta and customer satisfaction. It is also noted that external influences limit the operation of total quality management and customer focus in the organization. Based on the findings, we can conclude that if Colour Fiesta Nigeria Limited successfully set strategies that adopt quality management practices, it will have positive impact on customer satisfaction level. In addition, focusing on customers enhances business performance.

\section{Acknowledgement}

I would like to convey my heartfelt appreciation and love to my husband Harold Juwah who has constantly proofread this 
project, his unconditional support, and inspiration in every step of this study. My appreciation also goes to the staff and management of Colour Fiesta Nigeria Limited that gave their unreserved assistance in the survey that brought this project to a reality.

\section{References}

[1] Davies, E., 2003, Quality: Its historical context. Engineering Management pp. 14-17.

[2] Mehra, S., Hoffman, J. and Sirias, D., 2001, TQM a management strategy for the next millennia. International Journal of Operations and Production Management. 21(5/6) pp. 855-876, https://www.researchgate.net/.

[3] Hellsten,U. and Klefsjo, B., 2000, TQM as a management system consisting of techniques, values, and tools. pp 238-244.

[4] Seto-Pamies, D., 2012, Customer loyalty to service provider. Total Quality Management \& Business Excellence. pp. 1257-1271.

[5] Johnson, R., 2001, Linking Complaint Management to Profit. International Journal of Service Industry Management, vol 12(1) pp 60 - 69, https://docplayer.net/.

[6] Goldman, H., 2005, The origins and development of quality initiative in American business, The TQM Magazine. Vol. 17, No. 3, pp 217-25.

[7] Dow, D., Samson, D. and Ford, S., 1999, Exploding the myth: Do all quality management practices contribute to superior quality performance. Production and Operations Management 8, 1-27.

[8] Beer, M., 2003, The role of management quality and implications for leading a total quality management transformation. Decision sciences pp 623-642.

[9] Ritter, N., 2010, Understanding a widely misunderstood statistic. Cronbach's alpha. Southwestern Educational Research Association. 17(9), 167-175.

\section{Conflict of Interest Statement}

I declare that there is no conflict of interest in this study.

[10]Reichheld, F., 1993, Loyalty Based Management. Harvard Business Review. 71(2) pp 64-73.

[11]Bolton, R., 1995, Linking customer satisfaction to the duration of customer provider relationships and revenues. Waltham, MA. GTE Laboratories.

[12]Fornell, G., 1992, A national customer satisfaction barometer. The Swedish experience. Journal of Marketing 56, pp 1-18, http://www.sciepub.com.

[13]Boshoff, C., 1997, An Experimental study of Service recovery options. International Journal of Service Industry Management, vol 8(2) pp. 110 130, https://www.researchgate.net/.

[14] Campbell, A. and Yeung, S., 1991, Creating a sense of mission. Long Range Planning. pp 17 - 24 .

[15]Crosby, B., 1979, Quality is Free, Mentor, McGraw-Hill Book Company, New York.

[16]Huband, E., 1992, Developing effective management skills. Management Accounting, vol 74, pp 44-47.

[17]Kanji, G., 1998, Measurement of Business Excellence, Total Quality Management, Abingdon, Chapman \& Hall.

[18]Levy, P., 2003, Industrial/Organisational Psychology. Understanding the Workplace. Houston Mifflin, Boston, MA

[19] Schein, L., 1991, Communicating Quality in the Service Sector, The Conference Board, New York.

[20] Schein, E., 1992, Organisational Culture and Leadership, $2^{\text {nd }}$ edition, Jossey-Bass, San Francisco. [21]Texila American University, 2021, Total Quality Management. Retrieved June 10, 2021, https://dblplms.tauedu.org. 


\title{
Health Budget Allocation and Performance; and the Budget's Preparedness for Health Events such as COVID-19: Enugu State Perspective
}

\author{
Simon Nnamdi Eneh \\ Ph.D. in Public Health, Texila American University, Nigeria
}

\begin{abstract}
This is an exploratory study of the health budget allocation and performance of a State against the background of its health indices and preparedness for any public health emergency such as COVID19. This is aimed to guide future health programming in the state. Three research instruments (Questionnaire, data collection, and interview guides) were used to collect data, key informant interviews with health planners and managers; synthesis of relevant literature reviews to identify relevant documents; and responses gathered from the public and civil servants. The findings identified eight (8) Ministries, Departments, and Agencies (MDA) under the State Ministry of Health, which is the policy-making body that monitors and coordinates/regulates all health activities in the State. The government budget, donor partners, out-of-pocket expenditures, and contributory schemes are sources of funds for Health. The State's budgetary allocations for health shows an annual increment from reaching 15\% in 2016 to $16 \%$ in 2017 and over 17\% in 2018, surpassing the Abuja Declaration target of $15 \%$ of the state budget. In nominal terms, allocation to the health sector fluctuated between 2011 and 2016 and finally went down in 2018. There is no clearly cut-out budgetary provision for emergency preparedness for health events in the State's health budget. The government has proactively made budgetary provisions for the challenges facing the health care system to facilitate efforts towards addressing them. However, it remains to be seen whether the poor health indices will get better in the long run.
\end{abstract}

Keywords: Budget allocation, Emergency preparedness, Health economics, Health expenditure, Health financing, Health indices.

\section{Introduction}

Health budgets are the principal mechanism by which governments take decisions on health activities. According to [1], total health spending is growing faster than gross domestic product, increasing more rapidly in low- and middle-income countries (Close to $6 \%$ on average) than in high-income countries (4\%), noting that public spending on health is central to universal health coverage, but there is no clear trend of increased government priority for health. A huge portion of the resources consumed by the health sector are stationary e.g., investment in physical infrastructure and human resources, or largely preset e.g., salaries. The room for the operation of decision-makers is narrower than commonly thought. Thus, the internal structure of health expenditure is as important as its total cost. Considering health expenditure entails the analysis of the health sector in all its components. There is a huge mismatch between a country's health financing needs and their current health expenditure [1]. According to [2], developing countries constitute 84 percent of the world population and 90 percent of the universal disease burden, but only 12 percent of global health 
expenditure. The poorest countries bear an even higher portion of the burden of disease and injury, yet they have the least resources for financing health services [1].

Health is financed by public and private funds, and how the budgets are formed, allocated, and used in the health sector is at the center of the agenda for Universal Health Coverage [3]. Budget outcomes can be measured in terms of the aggregate level of spending, the composition of the spending, and the efficiency of spending. According to [4], public budgets are the instruments through which governments allocate the country's financial resources, including but not limited to financing health services. Even in the most open and democratic countries, a robust and transparent budget system can be difficult to achieve [4], emphasizing that supporting governments to strive towards achieving an open budget and improving the budget system can be a good starting point for any country's health budget advocacy. Bringing about changes in policy and budget allocations are often long-term objectives, and there will be many points during the budgetary process where one can make a change that will bring influence to bear and help re-shape the policy environment. It's important that one measures these benchmarks against the desired budget outcome so that one is able to monitor and evaluate what activities are being achieved.

Budget outcomes can be measured in terms of the aggregate level of spending, the composition of the spending, and the efficiency of spending.

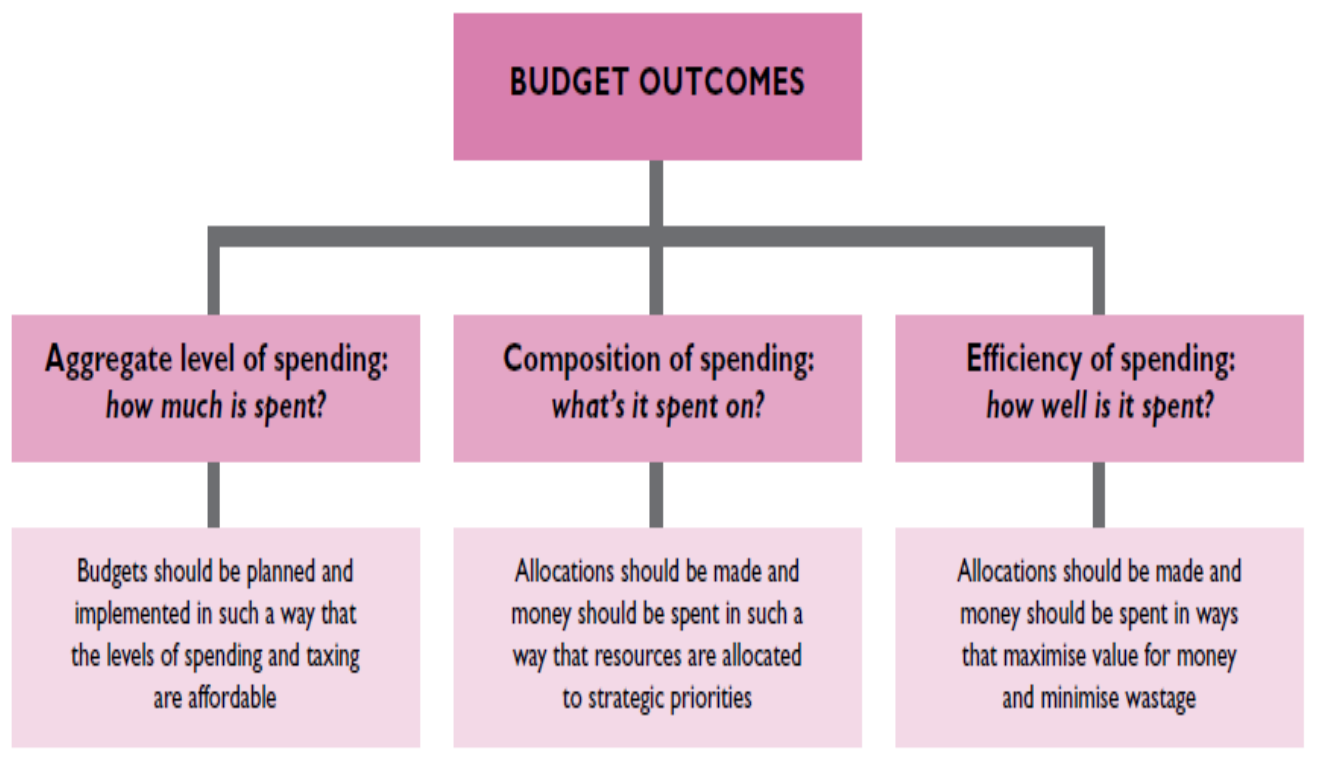

Figure 1. Budget outcomes: Level, Composition and Efficiency of Spending

Source: Save the Children, 2012

These various measures of levels, composition, and efficiency of spending are aligned respectively with different objectives as follows:

1. Budgets must be planned and implemented in a way that the levels of spending and taxing are affordable.

2. Allocations should be made, and money spent in such a way that resources are allocated to strategic priorities.
3. Allocations should be made, and money spent in ways that maximize value for money and minimize wastages.

The way a budget is formulated and allocated, especially at sub-national levels of government, has a direct impact on how well and how efficiently funds can and will be used. A fair distribution of resources across populations and/or geographical areas is likely to have a direct impact on health sector outputs 
[5]. Similarly, how health managers will be able to spend their money largely depends on what the budget allocation is [3]. Not only is the budget envelope amount relevant, but so too is how that total amount is structured, how it flows into the system, timing of disbursements, and how it will enable health financing to function in practice and to purchase the needed health services [3]. According to [6] in health, countries face challenges at all stages of the PFM cycle, including how to align budget allocations with sector needs, how to ensure effective disbursement, and how to make the budget system more accountable and transparent. These set of challenges also applies to States within the countries.

In Nigeria, money allocated to the health sector is amongst the bottommost. The Abuja declaration stipulates that $15 \%$ of the Budget is to be allocated to the health sector; however, that has not been achieved in most States and in the Nation [7]. If Nigeria hopes to reverse the trend of decline and realign its economy for allencompassing growth, then Nigeria will need to meaningfully upgrade its health sector budget. Furthermore, according to [8], Enugu State has poor health indices which are higher than the national average in terms of high maternal mortality (1400 per 100,000 live births; National 814 per 100,000 live births) and child mortality (40.6/1000 live births), moderate fertility, high literacy levels and above-average use of modern contraceptives. Bringing about changes in policy and budget allocations are often long-term objectives, and there will be many points during the budgetary process where one can make a change that will bring influence to bear and help re-shape the policy environment.

Specifically, this study looked at the following objectives:

1. To find out the health programs, projects and events funded in Enugu State between 2011 and 2017.
2. To ascertain how allocations of the health sector Budget are determined between 2011 and 2017.

3. To determine how the funds are released between 2011 and 2017.

4. To determine the provisions if any, made for emergency health events such as COVID-19.

Budget advocacy challenges the notion that public budgets are exclusively the business of government [4]. Regularly tracking disbursements (when funds are released) at particular points in the system and making comparisons with the budget allocations and schedule of disbursements, can indicate whether the funds are released regularly and spent as planned or if there are leakages. 'Leakages' refers to resources that are being disbursed but not spent as intended or resources that were disbursed but were not received and cannot be traced. As noted earlier, where there are capacity constraints, funds received may not always be spent in full and may be returned. The initial health budget's main concern might also change, which may require resources to be diverted during the budget period, which one should be able to track.

Comparing allocation and disbursement patterns over time can help stakeholders identify trends, which is particularly valuable when advocating for the various levels of government to fulfill any commitments made. Assessing the trends can reveal quickly how the government is progressing towards a specific target such as the Abuja target of allocating $15 \%$ of the budget to health.

According to [9, 10], 2019 Open Budget Survey reported that COVID-19 hit when growing inequality and weakening democracy moved people across the globe to call into question their governments' handling of public resources - a key theme of the 2019 Open Budget Survey report. The sheer scale of the interventions needed to confront the health and economic consequences of the COVID-19 pandemic has challenged governments' 
capacity to manage resources effectively and equitably in unprecedented ways $[9,10]$. In a research conducted to assess open governance practices on fiscal emergency packages by International Budget Partnerships and her local research partners in 120 countries, it was reported [9] that the main finding is that governments are falling short of managing their fiscal policy response to the crisis in a transparent and accountable manner as shown below.

Table 1. Levels of Accountability in Early Covid Fiscal Policy Response

\begin{tabular}{|c|c|c|}
\hline Level of accountability & No of countries (out of 120) & Countries \\
\hline Substantive & 0 & - \\
\hline Adequate & 4 & Australia, Norway, Peru, Philippines \\
\hline Some & 29 & $\begin{array}{l}\text { Bangaledesh, Brazil, Bulgaria, Canada, } \\
\text { Chile, Colombia, Costa Rica, Croatia, } \\
\text { Fiji, France, Germany, Indonesia, Italy, } \\
\text { Jamaica, Japan, Kyrgyz Republic, } \\
\text { Mongolia, New Zealand, Nigeria, } \\
\text { Paragauy, Poland, Portugal, Sierra } \\
\text { Leone, Slovakia, South Africa, Sweden, } \\
\text { United Kingdom, United States }\end{array}$ \\
\hline Limited & 55 & $\begin{array}{l}\text { Afghanistan, Angola, Argentina, } \\
\text { Armenia, Azerbaijan, Bolivia, Bosnia } \\
\text { and Herzegovina, Botswana, Cameroon, } \\
\text { China, Cote d'Ivoire, Czech Guatemala, } \\
\text { Honduras, Jordan, Kazakhstan, Kenya, } \\
\text { Lesotho, Liberia, Macedonia, } \\
\text { Madagascar, Malaysia, Mali, Mexico, } \\
\text { Moldova, Mozambique, Namibia, } \\
\text { Nepal, Nicaragua, Niger, Pakistan, } \\
\text { Papau New Guinea, Romania, Russia, } \\
\text { Rwanda, Senegal. Serbia, Somalia, } \\
\text { South Korea, Spain, Sri Lanka, Sao } \\
\text { Tome e Principe, Thailand, Timor- } \\
\text { Leste, Togo, Trinidad and Tobago, } \\
\text { Uganda, Ukraine, Vietnam, Zambia }\end{array}$ \\
\hline Minimal & 32 & $\begin{array}{l}\text { Albania, Algeria, Benin, Burkina Faso, } \\
\text { Burundi, Cambodia, Chad, Comoros, } \\
\text { Dem Rep of Congo, Egypt, Equatorial } \\
\text { Guinea, Eswatini, Ethiopia, Hungary, } \\
\text { India, Iraq, Lebanon, Malawi, Morocco, } \\
\text { Myanmar, Qatar, Saudi Arabia, South } \\
\text { Sudan, Sudan, Tajikistan, Tanzania, The } \\
\text { Gambia, Tunisia, Turkey, Venezuela, } \\
\text { Yemen, Zimbabwe }\end{array}$ \\
\hline
\end{tabular}

Source: IBP, (May 2021): p.3

More than two-thirds of the governments that were looked at, across many regions and income levels, have only provided limited or minimal levels of accountability in the 
introduction and implementation of their early fiscal policy responses $[9,11]$. In about half of the countries in the assessment, COVID-19 response packages took the form of supplementary budget laws (or other types of laws) approved by parliaments (even if in haste), guaranteeing some level of debate and accountability [9].

Countries that decided to have legislatures debate and approve their COVID-19 response packages did better in terms of both transparency and oversight $[9,12]$, emphasizing that even in times of crisis, it is possible to follow due process and maintain basic functional accountability processes. Decisionmaking around COVID response packages and their implementation includes very little or no input from the public. Citizen participation in the formulation and execution of COVID-19 policy responses was virtually non-existent, excluding the public from having a voice in decisions on priority-setting during the pandemic and depriving governments of contributions that could greatly improve the effectiveness of their actions [9]. Consequently, the government should take the opportunity provided by the COVID-19 health event to plan and implement their policy responses in a more open and collaborative way, emphasizing keeping citizens informed and promoting more effective and equitable outcomes [9].

The findings from this study are of significant benefit to individuals (Singly and in groups), the government, and the research world. The results will assist government and health administrators in health policy formulation, administration, and implementation for better service delivery. This study provides a baseline reference source for many researchers and the needed data that would assist the Enugu State Government, Health sectors, and other stakeholders in designing strategies and goals that will improve Universal Health Coverage. The findings of this study provide the basis for more realistic estimates of resources required in the State's health sector. Most importantly, it is believed that the findings from this study may stimulate further research and investment, which will ultimately improve the budget allocations to the Enugu state Health sector.

It is worthy of note that the analyses were based on documents available, with a few clarifications called for where needed. Moreover, the staff members' responses showed a bit of reluctance to offer the needed explanations, which made eliciting vital information and data quite challenging. Some government officials were uncooperative in terms of releasing documents on government finances, and the reason for such reluctance could not be elicited from some of them. As such, the study took more time and effort than estimated because the researcher spent more days to explain the need for the study since it is very important to gain the support of the public to collect and share information and data.

\section{Methods and Materials}

Three sets of instruments (One questionnaire, a data collection guide, and an interview guide) were employed to collect both quantitative and qualitative data. Data were collected from a sample of 40 relevant authorities (20 Public servants and 20 Civil servants) of the Ministries of Health and Finance in Enugu state and 160 respondents from the public.

The questionnaire was used for the public, the interview guide for the public servant and civil servants in both Ministries of Health and Finance, and the data collection guide used for desk review of available and relevant documents. All the respondents were further given an opportunity to provide information and suggestions on what they think would be helpful to enable improvement in health care budgeting in the State. The respondents' eligibility to participate included being residents in Enugu for at least 15 years, between 15 and 64 years of age, and 
willingness to participate. The overall response rate was $97.5 \%$.

Using the data collection guide, systematic reviews of official documents relating to budget allocations and releases for the period under review (2011 to 2017) was conducted in the Ministries of Health and Finance. The desk reviews of documents yielded quantitative data regarding budget allocations and performance status. These reviews allowed for analysis of the financial documents from various sources from 2011 to 2017. As such, the guide had sections that surveyed the following:

1. Health programs, projects and events funded in Enugu State between 2011 and 2017.

2. Key Projects with budgetary emphasis in Health Sector of Enugu state.

3. The proportion of Annual budget (2011 to 2017) that went to the Health Sector.

4. Enugu state health budget releases.

\section{Results}

\section{The organizational Structure of Enugu state}

The findings of the study showed that as the time of data collection, the Health Sector in Enugu State comprises eight (8) Ministries, Departments, and Agencies (MDA) under the leadership of the State Commissioner for the State Ministry of Health. The Enugu State Ministry of Health is the policy-making body cum monitors, and coordinates/regulates all Health activities in the State. Each of these is established by law and is granted a certain degree of autonomy. Other MDAs in the health sector are:

1. State Hospitals Management Board (SHMB) is responsible for all secondary Health outfits in the State.

2. The State Primary Health Care Development Agency (ENSPHCDA) is responsible for all the over 1000 primary Health Care (PHC) facilities in the State.

3. The State Drugs and Medical Consumables Management Agency (ENSDMMA) lumbered with the responsibility of logistics, supply, and distribution of medicine and medical consumables amongst all Health Facilities in the State.

4. The Specialist Hospital Board (SHB) function as a state-owned tertiary health facility.

5. The College of Nursing and Midwifery (CNM); is responsible for the training of the Human resources required by the State.

6. The College of Health Technology (CHT); responsible for the training of lower cadre of Human resource for Health.

7. The Enugu state health insurance agency.

8. The Enugu State Health Trust Fund; expected to be the source of funds for the health sector. The fund shall be generated from $5 \%$ of state internally Generated Revenue (IGR) and $1 \%$ of the statutory allocation of each of the local government councils of the state.

Each of these MDAs is autonomous in maintaining and implementing its budgetary provision as far as recurrent expenditure is concerned. However, capital funds are accessed through the Honorable Commissioner for Health's consent who endorses relevant memos to His Excellency the Executive Governor of the State for approval.

\section{The health Indices in the State}

The State health indices from the MICS survey in 2016 and 2017 and the NDHS 2018 showed significant disparity from the National Average as depicted in the table below: 


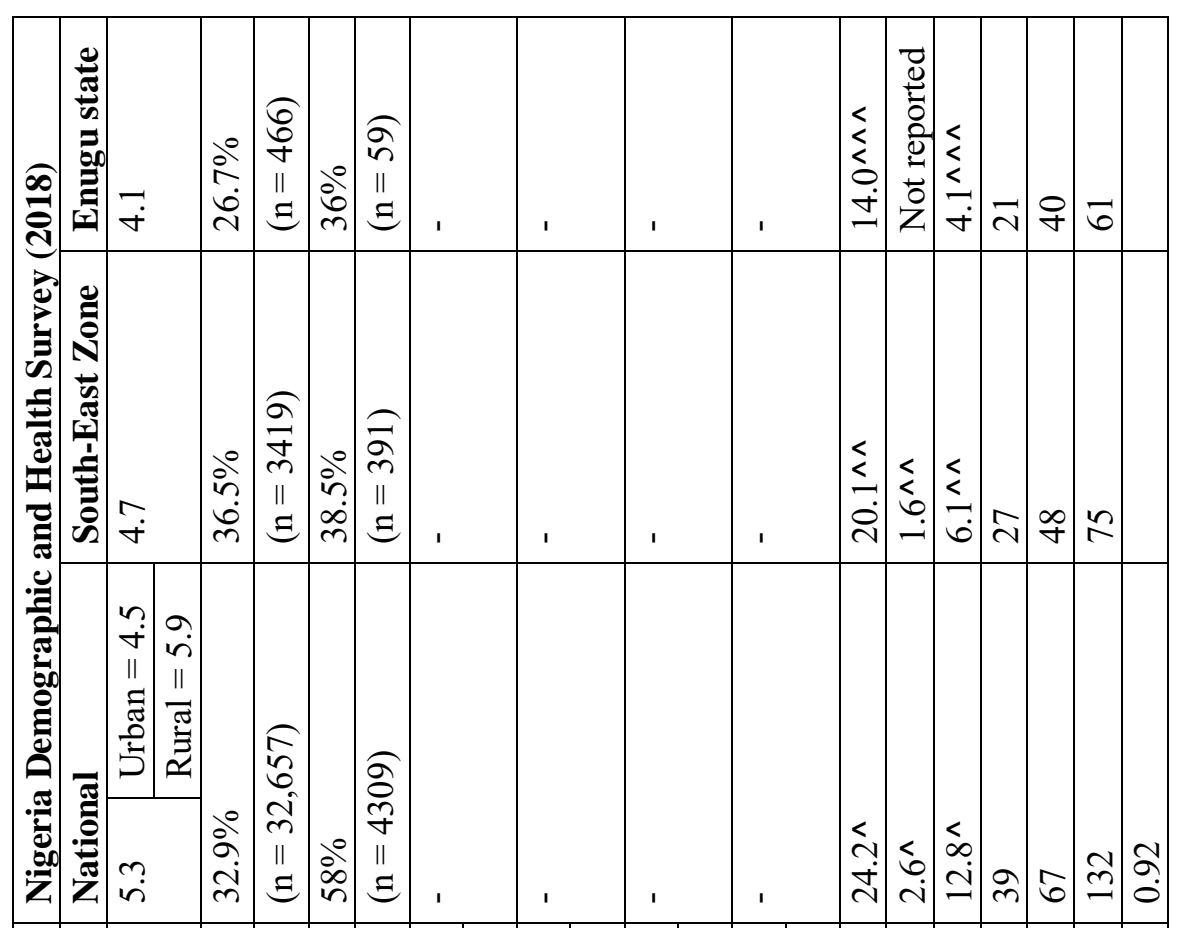

실.

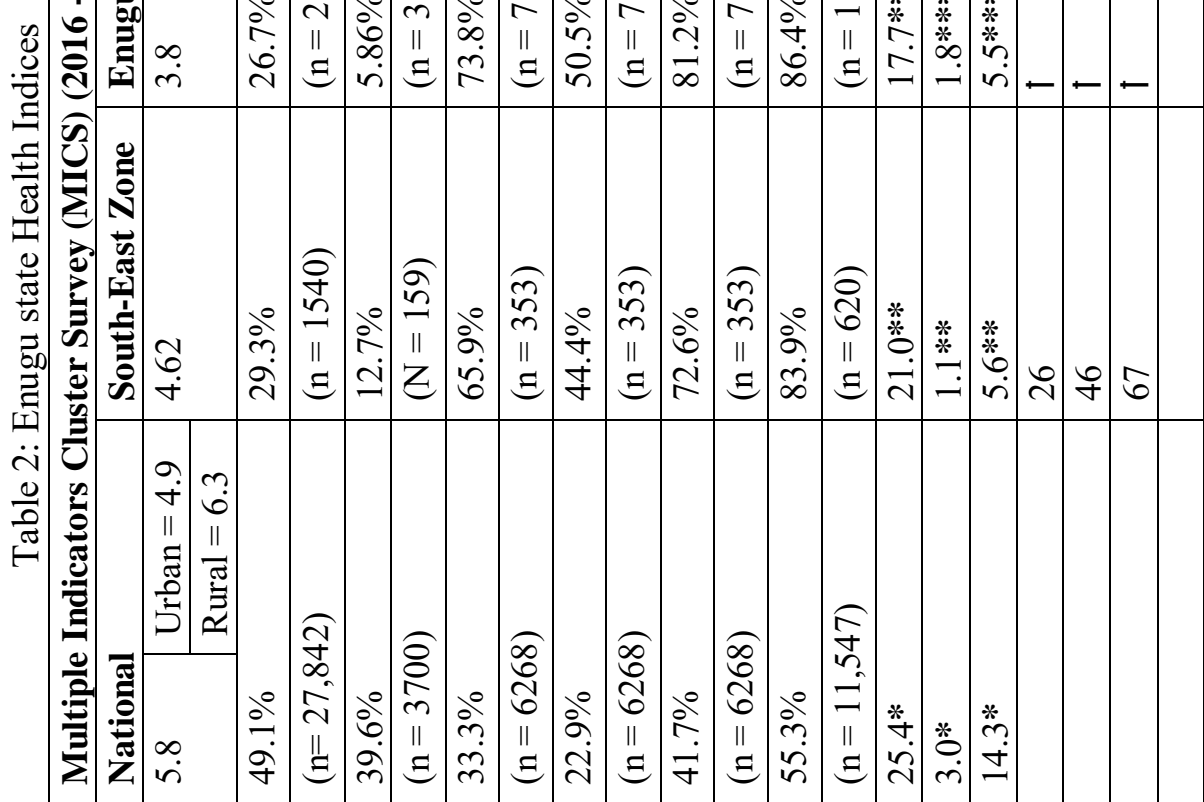

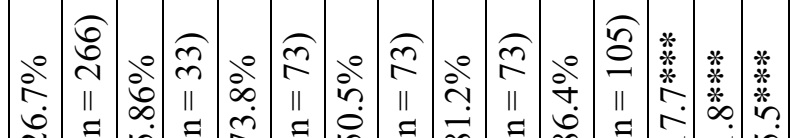

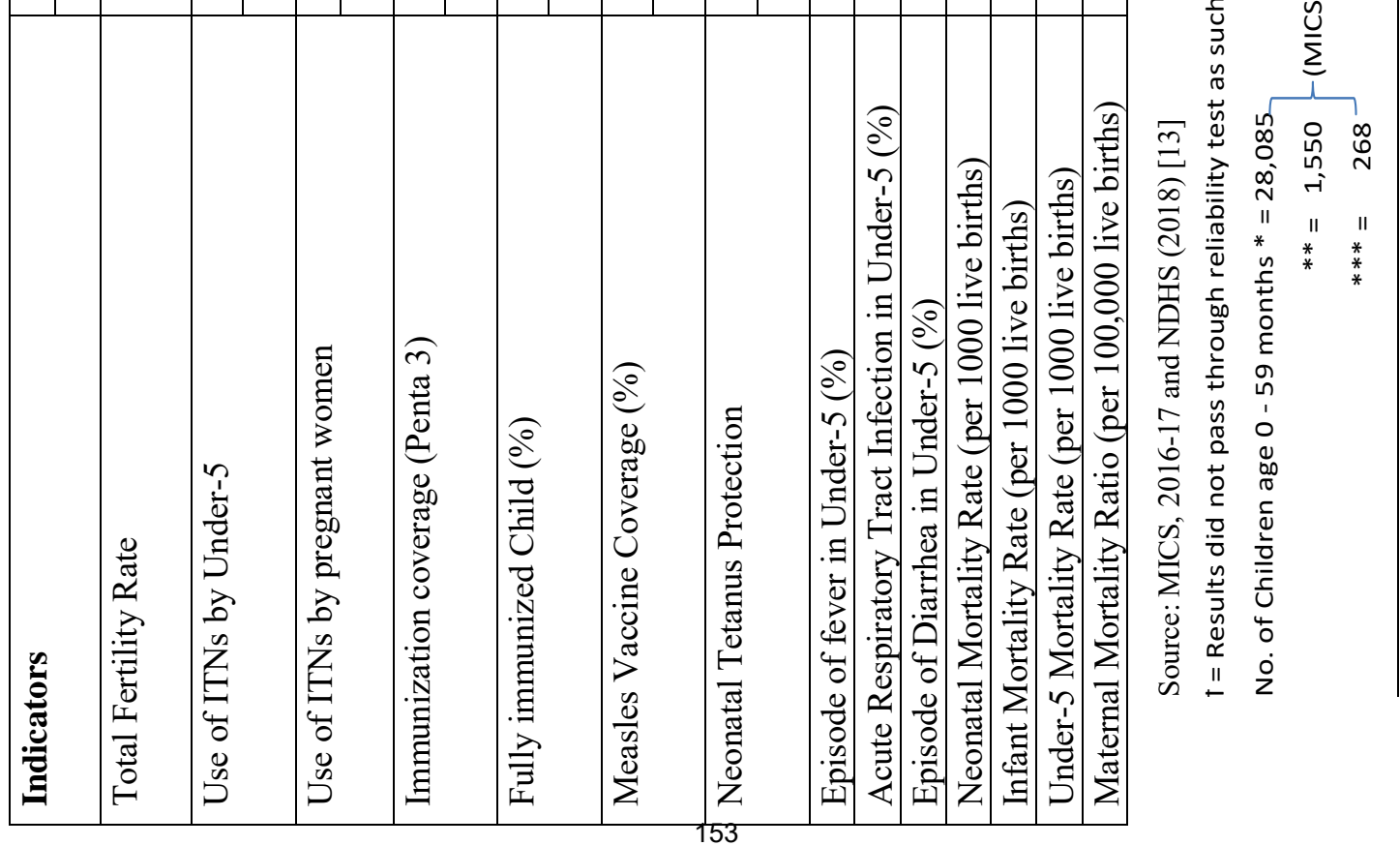




\section{The Sources of Funds for Health Programs, Projects and Events}

In general, sources of funds for Health in Enugu State were identified as:

1. Government budget (from Federal and State sources).

2. Donor partners - Through various health projects and initiatives.

3. Out of pocket expenditures from patients and relatives.

4. Contributory schemes (NHIS and few CBHIS Pilots).

However, the exact percentage of the total health budget for each Health program could not be clearly defined because inputs that impact on programs like maternal health, child health, and reproductive health cut across a number of capital and recurrent line items in the budget of various agencies within the sector.

\section{The Allocations of the Health Sector Budget}

Enugu State Government has made some giant strides recently; from 2006 to 2018, budgetary allocations for health constituted an average of $12 \%$ of the State's annual budget, with allocation reaching the Abuja Declaration target of $15 \%$ in 2016 and increasing further to $16 \%$ in 2017 and over $17 \%$ in 2018. Respondents consider the allocations and appropriation of health budget as adequate for 2017 and 2018, considering that the state has surpassed the Abuja declaration of $15 \%$ of state budget to the health sector.

In nominal terms, allocation to health sector decreased from 66.8billion in 2011 to 8.4billion in 2014 and reversed to 4.8 billion and rising to $\$ 6.4$ billion in 2016, in 2018, it went down $\$ 3.2$ billion.

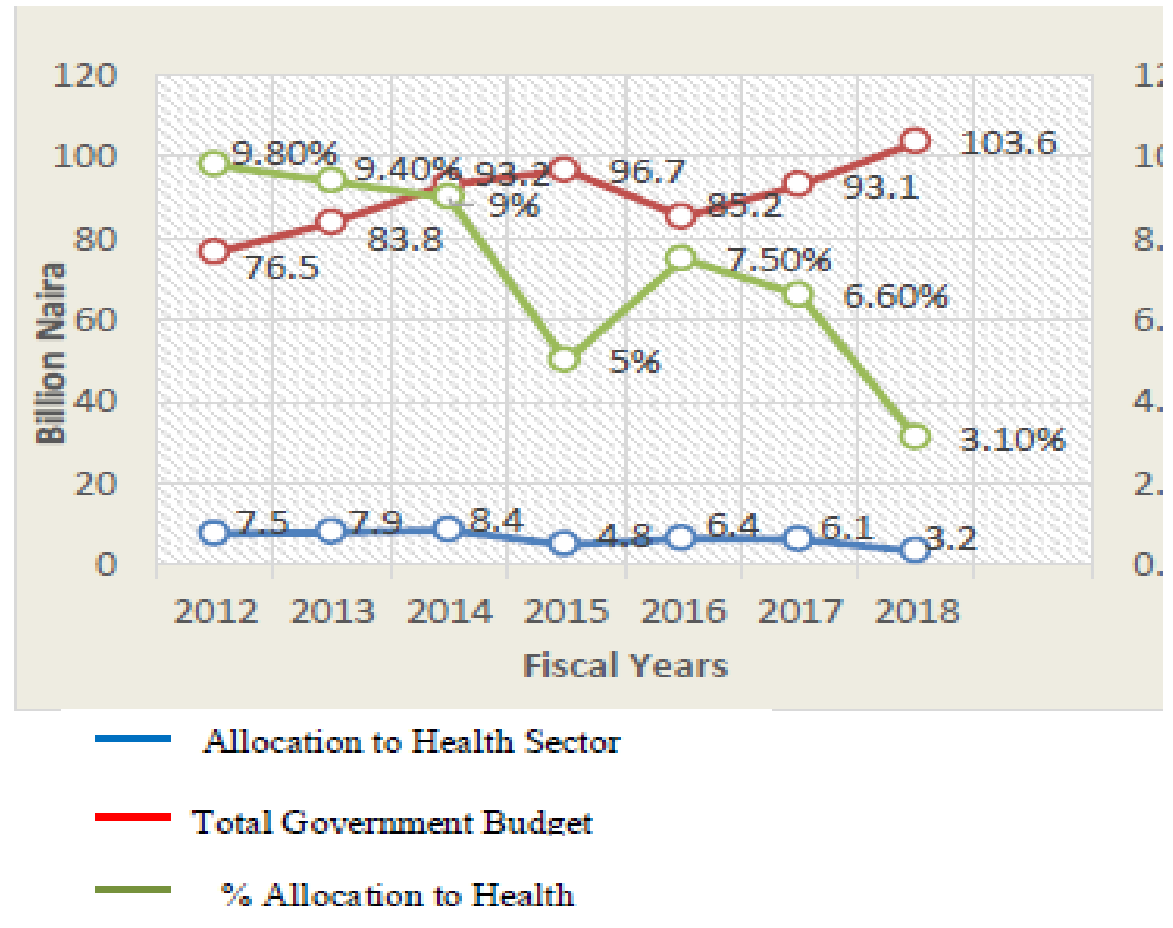

Figure 2. Enugu state Budget Allocation to Health 
Table 3: Enugu state Government Budget Allocation to Health

\begin{tabular}{|l|l|l|l|l|l|l|l|l|}
\hline Fiscal year & 2011 & 2012 & 2013 & $\begin{array}{l}201 \\
4\end{array}$ & 2015 & 2016 & 2017 & 2018 \\
\hline $\begin{array}{l}\text { Health budget allocation } \\
\text { (billion naira) }\end{array}$ & 6.8 & 7.5 & 7.9 & 8.4 & 4.8 & 6.4 & 6.1 & 3.2 \\
\hline $\begin{array}{l}\text { Total Government budget } \\
\text { (\%) }\end{array}$ & 66.4 & 76.5 & 83.8 & 93.2 & 96.7 & 85.2 & 93.1 & 103.6 \\
\hline $\begin{array}{l}\text { Government budget } \\
\text { allocation to health (\%) }\end{array}$ & 10.2 & 9.8 & 9.4 & 9.0 & 5.0 & 7.5 & 6.6 & 3.1 \\
\hline
\end{tabular}

Source: Enugu state Ministry of Finance (2019) [14]

From the above table, the allocation to health did not get to the $15 \%$ recommended by WHO. Furthermore, in spite of the meager amount of

\section{The Release of Funds for Health}

Table 4. Enugu State Health Budget Releases

\begin{tabular}{|l|l|l|l|l|}
\hline Year & $\begin{array}{l}\text { Total state budget } \\
\text { (billion naira) }\end{array}$ & $\begin{array}{l}\text { Health budget } \\
\text { (billion naira) }\end{array}$ & $\begin{array}{l}\text { \% Of budget } \\
\text { allocation to health }\end{array}$ & $\begin{array}{l}\text { Actual releases and } \\
\text { percentage (billion naira) }\end{array}$ \\
\hline 2011 & 66.4 & 6.8 & 10.2 & $4.4[64.7 \%]$ \\
\hline 2012 & 76.5 & 7.5 & 9.8 & $4.1[54.7 \%]$ \\
\hline 2013 & 83.8 & 7.9 & 9.4 & $5.8[73.4 \%]$ \\
\hline 2014 & 93.2 & 8.4 & 9.0 & $5.6[66.7 \%]$ \\
\hline 2015 & 96.7 & 4.8 & 5.0 & $4.2[87.5 \% \backslash$ \\
\hline 2016 & 85.2 & 6.4 & 7.5 & $5.8[90.6 \%]$ \\
\hline 2017 & 93.1 & 6.1 & 6.6 & $5.5[90.2 \%]$ \\
\hline
\end{tabular}

Source: Enugu state Ministry of Finance (2019) [14]

From the Table above, the actual releases from the budget allocation showed increases from 2011 through 2017, except for slight fluctuations.

\section{Preparedness for Emergency Health Events such as Covid-19}

Regarding emergency preparedness for health events such as COVID-19, the findings showed that there is no such budgetary provision in the health budget through the years studied.

\section{Discussion}

\section{The Organizational Structure of Enugu State}

The Health Sector comprises of the following health institutions to work money allocated to health. The amount eventually released is reasonably high. collaboratively to strive towards optimum health outcomes for the residents of the State.

1. State Hospitals Management Board (SHMB) is responsible for all secondary Health outfits in the State.

2. The State Primary Health Care Development Agency (ENSPHCDA) is responsible for all the over 1000 primary Health Care (PHC) facilities in the State.

3. The State Drugs and Medical Consumables Management Agency (ENSDMMA) is lumbered with the responsibility of logistics, supply, and distribution of medicine and medical consumables amongst all Health Facilities in the State.

4. The Specialist Hospital Board (SHB) functions as a state-owned tertiary health facility. 
5. The College of Nursing and Midwifery $(\mathrm{CNM})$; is responsible for the training of the Human resources required by the State.

6. The College of Health Technology (CHT); responsible for the training of lower cadre of Human resource for Health.

7. The Enugu State Ministry of Health is the policy-making body cum monitors, and coordinates/regulates all Health activities in the State. Each of these MDAs is autonomous in maintaining and implementing its budgetary provision as far as recurrent expenditure is concerned. However, capital funds are accessed through the Honorable Commissioner for Health's consent, who endorses relevant memos to His Excellency the Executive Governor of the State for approval. New agencies were created in 2018 by signing of law for their establishment, and these agencies are.

8. The Enugu state health insurance agency.

9. The Enugu State Health Trust Fund; expected to be the source of funds for the health sector. The fund shall be generated from $5 \%$ of state internally Generated Revenue (IGR) and $1 \%$ of the statutory allocation of each of the local government councils of the state.

The state health system operation is predicated on the existing policy of the federal government thus, tertiary health care is the responsibility of the federal government, the secondary and primary health care are those of the State and the Local Governments, respectively. However, the two sub-national tiers of government collaborate and complement each other with the aim of meeting the health needs of the people in the State.

The State Ministry of Health directs, monitors, and supervises all health services in the state, and is saddled with the responsibility of health manpower development and organization and implementation of secondary health care. The State agency -- State Primary Health Care Development Agency oversees the
Primary Healthcare facilities under the policy of Primary Health Care Under One Roof (PHCUOR), and in collaboration with the local governments, supervises the primary health care and diseases control. The Local Government in conjunction with the ENSPHCDA, organizes and implements primary health care activities at the community level and is also responsible for funding and coordinating services delivery at the grassroots level.

\section{The health Indices in the State}

It is noteworthy that the health indices in the State fluctuate over time when compared with the Nation and the Zonal data. Moreover, it may not be surprising that the health indices in the State remained somewhat static without improvement between reports as published by 2017 MICS [13] and that of the 2018 NDHS [8].

According to [15], some studies conducted in African countries have demonstrated an association between medical outcome and healthcare expenditures and a statistically significant relationship between health expenditures and health outcomes. Although this study was not set up to explore this relationship, it can be seen that the health indices in the State were static over the years despite an upward trend in budget allocations which were not matched with expenditures.

\section{The Sources of Funds for Health Programs, Projects, and Events}

The main source and highest contribution of funding is from the government budget. It is of note that the government has prioritized health over other institutions, and health budget has been the second-highest in the state over a decade.

Development assistance in Enugu state contributes close to $14 \%$ of the budget on health, while the state internally generated revenue constitutes just about $11 \%$ of the total budget [14]. The Enugu State Health Trust 
Fund is to be generated from $5 \%$ of State IGR and $1 \%$ of the statutory allocation of each of the local government councils of the state, also expected to be functional in 2018 is still in the teething stage.

The exact percentage of the total health budget for each health program could not be clearly defined because inputs that impact on programs like maternal health, child health, reproductive Health cut across a number of capital and recurrent line items in the budget of various agencies within the sector. As an example, the Elimination of Mother to Child Transmission of HIV services which is a component of reproductive, Maternal, Neonatal, and Child Health, is captured as a budget line for the Enugu State Agency for Control of Aids, TB, and Malaria. In addition, capital expenditure such as refurbishing facilities or the purchase of equipment that contribute to improved delivery of $\mathrm{RMNCH}$ services has a broad impact on the entire health system. However, certain programs have been given prominence and are captured separately in the state Budget. These programs include Routine Immunization, Nutrition and Child spacing (Family Planning).

\section{The Allocations of the Health Sector Budget}

The State adopted the medium-term Expenditure Framework (MTEF), which is in line with the State Fiscal Responsibility Amendment Law 2009. This is an integrated approach to budgeting and public financial management for the harmonization of all expenditure programs with available resources. It MTEF forecasts likely available resource over 3years and link the annual spending of MDAs with government long-term strategies as articulated under the various state developmental plans/policies. Using the Medium-term sector as a subset of MTEF envelopes are determined for the health MDAs. Despite the use of the MTSS as a financial and planning tool, responders still think that the health sector Budget preparation is fragmented and uncoordinated. On receipt of Budget call circulars from the Department of Budget Monitoring and Evaluation, the ministry of health only prepares Budget for itself under the department of PRS, and in consultation with relevant stakeholders, same is done independently by other Health MDAs, after which MDA defend their Budget in the House of Assembly. Funds are allocated directly to the respective MDA. It is therefore not uncommon to find duplication of programs/activities in the health sector Budget.

Enugu State Government has made some giant strides recently; from 2006 to 2018, budgetary allocations for health constituted an average of $12 \%$ of the State's annual budget, with allocation reaching the Abuja Declaration target of $15 \%$ in 2016 and increasing further to $16 \%$ in 2017 and over $17 \%$ in 2018 and $20 \%$ in 2019. In addition to progressive budgetary allocations, the health sector also experienced increased participation of Civil Society Organizations and community-based organization in budget planning and monitoring of implementation. Regular meetings between the CSOs, CBOs, and the state and LGA health officials also led to increased efficiency and accountability in the utilization of budgetary funds at the LGA and state levels.

\section{The Release of Funds for Health}

In nominal terms, allocation to the health sector decreased from 2014 and reversed in 2016, and in 2018 it went down. Budgeting allocation for health is meaningless without consideration of budget release and utilization in the sector, which constitute critical factors reviewed by ministries responsible for allocating and disbursing public budgetary resources. Funding approvals are centralized at the level of the Governor. While acting, the Deputy Governor has an approval limit. At the level of the Ministry of Finance and Accountant Generals office, there are many other competing sector demands. 


\section{Preparedness for Emergency Health}

The State health Budget did not provide for emergency situations in health. The COVID-19 pandemic has stimulated thoughts among policy and decision-makers that should drive the budget provisions and budgeting process going forward.

More than two-thirds of the governments that were looked at, across many regions and income levels, have only provided limited or minimal levels of accountability in the introduction and implementation of their early fiscal policy responses $[9,10]$. It is also noted that in about half of the countries in our assessment, COVID-19 response packages took the form of supplementary budget laws (or other types of laws) approved by parliaments (even if in haste) guaranteeing some level of debate and accountability; and that countries that decided to have legislatures debate and approve their COVID-19 response packages did better in terms of both transparency and oversight, emphasizing that even in times of crisis it is possible to follow due process and maintain basic functional accountability processes [9]. It has been reported that decision-making around COVID response packages and their implementation includes very little or no input from the public [9]. It has also been stated that citizen participation in the formulation and execution of COVID-19 policy responses was virtually non-existent [9]. This has resulted in excluding the public from having a voice in decisions on priority-setting during the pandemic and depriving governments of contributions that could greatly improve the effectiveness of their actions [9]. Thus, the government is required to take the opportunity provided by the COVID-19 health event to plan and implement their policy responses in a more open and collaborative way, emphasizing keeping citizens informed and promoting more effective and equitable outcomes [9].

\section{Conclusion}

The Enugu State's poor health indices, which are higher than the national average, and the other challenges facing the health care system, has recently caused the state to increase budgetary allocation to the health sector to facilitate efforts to address the many challenges in that sector. However, it remains to be seen whether the poor health indices will get better in the long run.

The State Ministry of Health needs to constantly and collaboratively work with the State Ministry of Finance to prioritize activities of the health sector and facilitate releases. There is also a need for a more realistic health budget that can be matched by expenditure in other to improve health outcomes. As such, emphasis should be on policies to address the numerous bottlenecks encountered in releases of funds towards health programs. Partners need to provide support to the government towards improving internally generated funds that will enhance sustainability and the development of realistic budget estimates. The need to further understudy the pattern of health budget allocation and performance from 2018 to 2021 cannot be overestimated to inform future decisions.

\section{Conflict of Interest}

None associated with this study.

\section{Acknowledgement}

I am grateful to the Texila America University that gave me the opportunity to study a doctoral degree in public health at this great and renowned institution. Thank you for providing a vigorous learning environment for me and for encouraging creativity, interaction, and participation in academic interactions between the University and her students. I am grateful to the entire faculty, mentors, academic coordinators, and team in the administrative section of this institution. 


\section{References}

[1] Xu K, Soucat A \& Kutzin J et al. (2018). Public Spending on Health: A Closer Look at Global Trends. Geneva: World Health Organization; 2018 (WHO/HIS/HGF/HFWorkingPaper/18.3). Licence: CC BY-NC-SA 3.0 IGO.

[2] Gottret, Pablo; Schieber, George. 2006. Health financing revisited: a practitioner's guide (English). Washington, DC: World Bank. http://documents.worldbank.org/curated/en/8740114 68313782370/Health-financing-revisited-apractitioners-guide.

[3] Rajan, D., Barroy, H, and Stenberg K., (2016). Budgeting for health. In: Schmets G, Rajan D, Kadandale S, editors. Strategizing national health in the 21st century: a handbook. Chapter 8. Geneva: World Health Organization. http://apps.who.int/iris/bitstream/handle/10665/2502 21/9789241549745-chapter8eng.pdf? sequence $=11$ \&isAllowed $=y$.

[4] Save the Children, (2012). Health Sector Budget Advocacy: A guide for civil society organisations. https://www.who.int/pmnch/media/news/2012/2012 05_health_sector_budget_advocacy.pdf.

[5] Cashin, C., (2016). Health financing policy: the macroeconomic, fiscal, and public finance context. Washington (DC): World Bank Group. http://documents.worldbank.org/curated/en/3940314 67990348481/Health-financing-policy-themacroeconomic-fiscal-and-public-finance-context.

[6] WHO, (2018). Public Spending on Health: A Closer Look at Global Trends. WHO/HIS/HGF/HFWorkingPaper/18.3.

http://apps.who.int/iris.

[7] Kress Daniel H., Su Yanfang and Wang Hong (2016). Assessment of Primary Health Care System Performance in Nigeria: Using the Primary Health Care Performance Indicator Conceptual Framework. Health Systems \& Reform, 2(4):302-318, 2016 2016 Bill and Melinda Gates Foundation ISSN: 2328-8604 print $/ 2328-8620$ online DOI: $10.1080 / 23288604.2016 .1234861$.

[8] Nigeria Demographic and Health Survey (2018). National Population Commission Abuja, Nigeria. The DHS Program ICF Rockville, Maryland, USA October 2019.
[9] International Budget Partnership, (May 2021). Managing COVID funds: The accountability gap. https://internationalbudget.org/covid/.

[10] Organization for Economic Cooperation and Development (10 May 2021). The territorial impact of COVID-19: Managing the crisis and recovery across levels of government https://www.oecd.org/coronavirus/policyresponses/the-territorial-impact-of-covid-19managing-the-crisis-and-recovery-across-levels-ofgovernment-a2c6abaf/.

[11] United Nations (April 2020). Policy Brief: The Impact of COVID-19 on Women https://reliefweb.int/sites/reliefweb.int/files/resource s/policy-brief-the-impact-of-covid-19-on-womenen.pdf.

[12] World Health Organization, (2022). Health Budget: Overview. https://www.who.int/healthtopics/health-budget $\#$ tab=tab_1.

[13] National Bureau of Statistics (NBS) and United Nations Children's Fund (UNICEF). (2017) Multiple Indicator Cluster Survey 2016-17, Survey Findings Report. Abuja, Nigeria: National Bureau of Statistics and United Nations Children's Fund. https://www.unicef.org/nigeria/sites/unicef.org.niger ia/files/2018-09/Nigeria-MICS-2016-17.pdf.

[14]Enugu State Ministry of Budget and Planning (July 2018). Enugu State Health Expenditure Report, 2018. 2018 Second Quarter and Mid-Year Budget Implementation Report.

[15]Bein, Murad, and Coker-Farrell, Elizabeth Y., (Mar 2020). The association between medical spending and health status: A study of selected African countries Malawi Med J.; 32(1): 37-44. doi: $10.4314 / \mathrm{mmj}$. v32i1.8. https://www.ncbi.nlm.nih.gov/pmc/articles/PMC736 $6161 /$. 


\title{
Citizen Participation in Health Budget Process: Trends and Patterns with Particular Reference to Enugu State of Nigeria
}

\author{
Simon Nnamdi Eneh \\ Ph.D. in Public Health, Texila American University, Nigeria
}

\begin{abstract}
This study looked at Citizen Participation in Health Budget Process: Trends and Patterns in Enugu state of Nigeria. The study's objectives included exploring citizens' perception of the factors that influence the release of funds in the State, their level of participation, and knowledge about the goals of citizen participation in the budget process. Respondents were 398 in number (198 males and 200 females), inclusive of 40 civil and public servants. The two sets of questionnaire were used to collect data (One set for the public and civil servants; and the other set for the general public. Results reveal that the factors that influence the release of funds include, among others, poor allocation and release of funds from federal sources and weak political commitment. The results also reveal that citizens are not openly and substantially involved in the health budget process, and their level of knowledge regarding the government's goal in citizen participation in the budget process is poor. The findings from this study will inform the development of advocacy packages to the government towards greater and meaning engagement of the citizens in the budget process. The advocacy packages might give the necessary voice to the people, which are required to strengthen efforts towards the attainment of Universal Health Coverage, as well as generate useful data which will serve as a guide for future interventions.
\end{abstract}

Keywords: Budgetary process, Citizen Participation, Health care financing, Health Sector Funding, Participatory budgeting, People-Task-Oriented Budgeting.

\section{Introduction}

The first wealth of any nation is the health of her populace. The health of a Nation is greatly determined by the belief that people have a right to influence public choices, especially relating to health issues that shape their lives. Health is financed by public and private funds, and how the budgets are formed, allocated, and used in the health sector is at the core of the Universal Health Coverage (UHC) agenda [1]. Bringing about changes in policy and budget allocations are often long-term objectives, and there will be many points during the budgetary process where one can make a change that will bring influence to bear and help re-shape the policy environment.
According to [2], public budgets are the instruments through which governments allocate the country's financial resources, including but not limited to financing health services. Even in the most open and democratic countries, a robust and transparent budget system can be difficult to achieve, calling attention to the fact that supporting governments to strive towards achieving an open budget and improving the budget system can be a good starting point for any country's health budget advocacy [2]. A good understanding of the budget process and solid engagement by the Ministry of Health and other health sector stakeholders at the right time during the budget cycle will increase the probability of a match between the ultimate 
resource allocation and the planned health sector needs. For instance, preparedness for health events/emergencies is like a protection policy for the health and prosperity of the populace of any State. Although it is hoped that a deadly epidemic does not occur, there is a need to ensure that every State of any country is always ready with budgetary provisions.

Budgets are the business of all citizens, including children and young people, as they are the rights-holders whose needs the government designs services to meet, budget advocacy can bring citizens closer to the decision-makers who affect their everyday lives, thus promoting transparency and accountability [2]. It's the duty of the government to provide for these rights, for which the citizens may hold their government accountable. The populace also has a right to influence government's decisions on how public resources are spent, both across and within sectors. Stakeholders at diverse levels are engaging more and more in analyzing and influencing government budgets on health, among other services, resulting in a greater say in government's decisions about spending priorities.

This study is formative research that explores the State's budgetary process (The trend and pattern) in the health sector. Specifically, the objectives were to:

1. Identify the factors that influence the release of funds in the State between 2011 and 2017.

2. Determine citizens' level of participation (Engagement, scope, and mechanisms) in the budget process of the health sector.

3. Ascertain the citizens' knowledge about the goals of citizen participation in the budget process.

The results are hoped to assist government and health administrators in health policy formulation, administration, and implementation for better service delivery. The study contributes to the development of the advocacy packages to the various key and relevant stakeholder groups at various levels of government. This package might give the necessary voice to the people, which are required to strengthen efforts towards the attainment of Universal Health Coverage, as well as generate useful data which will serve as a guide for future interventions. This study also provides a baseline reference source for many researchers and the needed data that may assist the Enugu State Government, health sectors, and other stakeholders in designing strategies and goals that will improve the Universal Health Coverage.

Literature on relevant and related articles shows that a budget is a financial plan prepared and used to estimate revenues to be generated and expenditures to be made in a specific period of time. It is a tool used not just as an accounting document but also supports and facilitates the allocation of funds as in planning and managing resources. According to [1], the health budget is the portion of the national budget allocated to the health sector, including all ministries and agencies involved in health-related activities. A health budget is more than a simple accounting instrument to present revenues and expenses rather, it is a crucial orienting text declaring the country's key financial objectives and its real commitment to implementing its health policies and strategies [1].

Fundamentally, developing strong health budget envelopes calls for strong and collaborative engagement with the relevant ministries, decision-makers, and their stakeholders, to make the health sector perspective clear, logical, and convincing. The way budgets are developed, allocated, and used in the health sector is crucial and at the centre of any health agenda, including the agendas for health emergencies. Ministries of Finance and related entities are the leading institutions for budget development, while Ministries of Health $(\mathrm{MOH})$ have the critical responsibility to prepare, present, negotiate and defend the credibility and priority-orientation of the 
proposed budget for the health sector. Relevant stakeholders (Civil society and the general public) can seek to contribute to health budget definition by engaging with the executive or the legislature. A sound understanding of the budget process and solid engagement of all relevant stakeholders at the right time during the budget process cycle by $\mathrm{MoH}$ will increase the likelihood that the final resource allocation matches planned health sector needs strategically. In the budgeting process, the allocation of resources to various institutions and for diverse purposes is basically a political rather than a purely bureaucratic process. As a result, after analyzing the needs and determining the most equitable and efficient policies and plans, stakeholders in health must be proactively engaged in this politically influenced process, as this engagement of relevant stakeholders determines the details and the relevance of the health budget, which impacts on effectiveness and efficiency of public spending for health.

In other words, how a budget is formulated and allocated to include the lower levels of government, such as the public, has a direct effect and impact on how effectively and efficiently funds can and will be used. Supporting a fair distribution of resources across populations and/or geographical areas is likely to have a direct impact on health sector outputs [3]. Where the health policy-making, planning, costing, and budgeting take place in parallel and independently of each relevant stakeholder group, it usually leads to a misalignment between the health sector priorities as stipulated in the overall strategic plans and policies, and the funds that are eventually allocated to the health sector through the budgeting process. This misalignment results in negative consequences as resources are not used as intended and planned, and accountability is lacking or weakened.

Citizen participation in budgetary processes is an arrangement that should be consciously put forward by an efficient and responsive government to actively and meaningfully engage citizens and have them make inputs into resource allocation decisions. Participatory budgeting is as a process that is open to any citizen who wants to participate and that combines direct and representative democracy, involving deliberation (not merely consultation), redistributes resources toward the poor, and is self-regulating, such that participants help define the rules governing the process, including the criteria by which resources are allocated [4]. Implicit in the definitions is the fact that in a participatory budgeting system, citizens have the right to say how part of the public resources should be spent [5]. It is not only about the decision itself but also a complex process including the identification of needs, formulation of needs, discussions, and prioritizing some of these needs [5]. The participatory budgeting programmes are implemented at the behest of governments, citizens, Non-Governmental Organizations (NGOs), and Civil Society Organizations (CSOs) to allow citizens to participate directly in deciding how and where resources should be spent [5]. According to [5], the practice of promoting deliberative democracy through citizen participation in budgetary decision making has been widespread for several decades now, buttressing that from an international perspective, the best-known form of citizen participation in budgeting is the Porto Alegre model, considered the initial attempt at participatory budgeting. In 1988, the progressive Workers' Party won the mayoral election in Porto Alegre, Brazil, explaining that in Porto Alegre, the government, together with civil society groups, experimented with a participatory budgeting program aiming to invert the budget's priorities by shifting resources from middle- and upper-class neighborhoods to lower-class ones [5], emphasizing that participatory budgeting has since spread to cities worldwide. 
Although participatory budgeting was developed and invented in Porto Alegre, the implementation of this system differed significantly in different countries [5]. It has been demonstrated that the models adopted by other countries in Europe for the implementation of participatory budgeting were unique to the conditions found in the area [6]. However, the core ingredient of participatory budgeting is participation, deliberation, empowerment and control, and monitoring, all of which should be decentralized. Participatory budgeting in developing countries should be advocated for by underlining its merits as promoting social justice and good governance and transparency by providing the government with information and facts that improve allocative or technical efficiency [7]. This is true as public inputs most times recommend innovative solutions that would not have been obvious from traditional modes of decision making. This study is based on a classic (People-Task-Oriented Budgeting) approach that considers the budget process as a system of interdependent actors (Citizens and government officials) behaving in a way to adequately response to control bottlenecks in their environment during the budget process. The formulated theoretical framework (PeopleTask-Oriented Budgeting Model) tries to explain the interconnectedness of actors in the budget process, proposing that when the external environment becomes more uncertain, the budget process requires increasing use of integrated mechanisms, such as budgetary participation to coordinate actions. The Figure below illustrates the relationship between the environment and the budget process as in the formulated People-Task-Oriented Budgeting Model for the study.

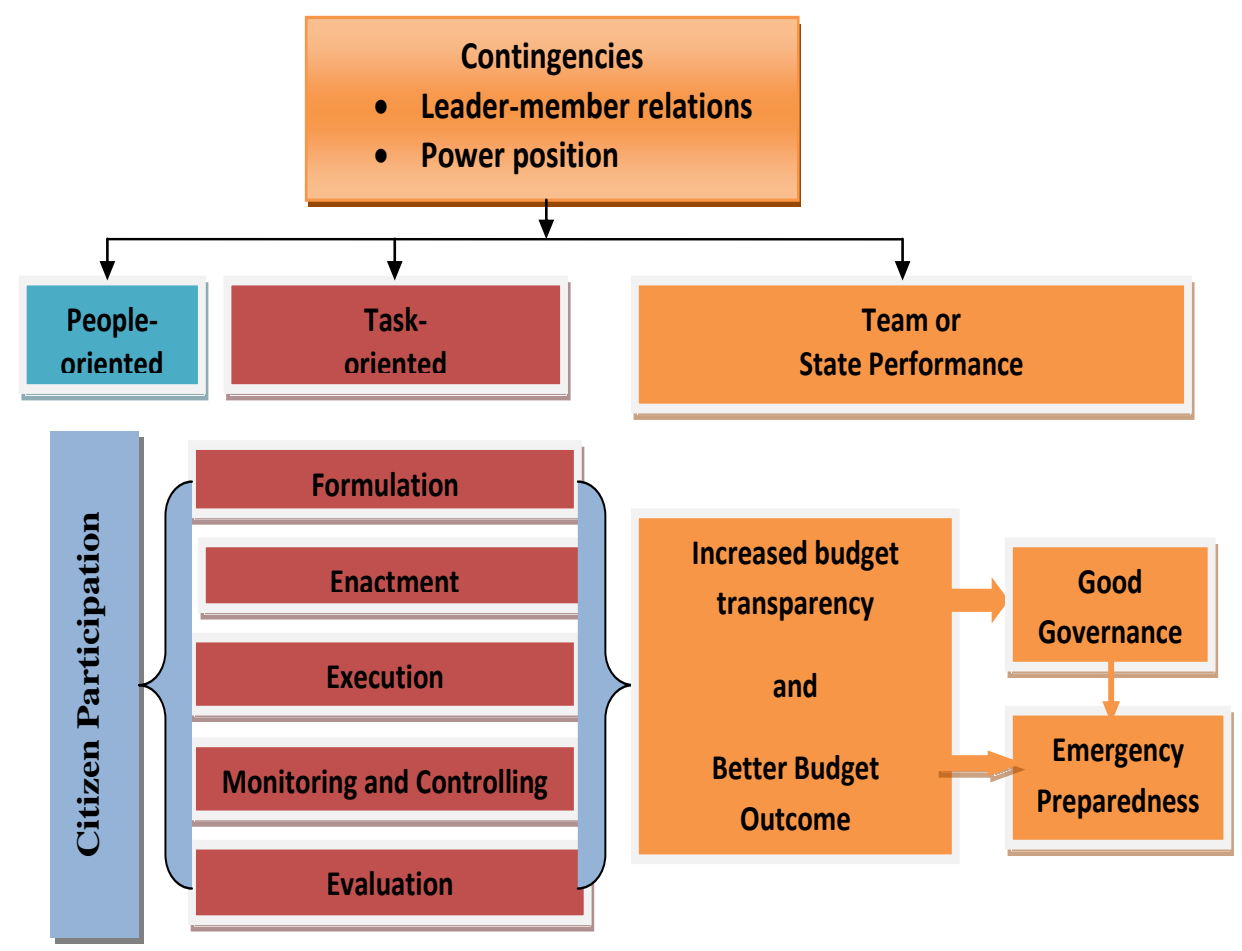

Figure 1. Formulated People-Task-Oriented Budgeting Model for the Study

This relationship postulates that the budget process being contingent on sound governmentpeople relations will bring about high performance. Participation in the budget process can guide citizens to convey their preferences at the various stages of the budget process to their governments, thus strengthening citizens' participation potential. This ensuing strength may, in turn, lead to a more responsive and effective government. Citizen participation is seen to have the likelihood to lead to better governance because 
a narrower distance between government and citizens can make public officials and government more accountable to citizens. The amount of information that is required for decision-making depends on the external environment, since as the environmental uncertainty increases, more relevant information for planning will be sought for [8]. Budgetary participation will provide more useful results when environmental uncertainty is high [8].

Through citizen engagement and participation in the budget process, it is envisaged that the distance between citizens and government officials becomes somewhat less significant. Such collaboration in the budget process gives interested citizens access to more and better information about governments and at the same time, gives the government deeper information about citizens' needs and preferences. Governments are more likely to have good budgetary outcomes if the citizens are involved at every of these three principles of the budget system: drafting (formulation), the legislative process (enactment), implementation (execution), along with auditing, execution (Implementation), monitoring and evaluation. Thus, it is very important that governments carry the public along and meaningfully engage them on the budget issues such as what taxes to levy, what services to provide, and how much debt to take on as these are crucial decisions that affect to a large extent the lives of the people.

The OBS is the world's only independent, comparative, and fact-based research instrument that uses internationally accepted criteria to assess public access to central government budget information; formal opportunities for the public to participate in the national budget process; and the role of budget oversight institutions such as the legislature and auditor in the budget process [9]. The 7th edition of the OBS was conducted in 117 countries of the world in 2019, of which Nigeria was one of them [9]. The survey looked at transparency, public participation, and budget oversight of the budget process. The transparency section of the OBS measures public access to information on how the central government raises and spends public resources, the online availability of the budget, timeliness, and comprehensiveness of eight key budget documents with 109 equally weighted indicators and a scale of 0 to 100 to score each country [9].

On transparency of the budget process, the Open Budget Survey (OBS) indicated that Nigeria has a transparency score of 21 (out of 100) compared to the other 116 countries, thus ranked: 97 out of 117 countries [9]. The global average is 45 [9].

Table 1. Transparency in Nigeria Compared to Others

\begin{tabular}{|l|l|}
\hline Global Average & 45 \\
\hline Ghana & 54 \\
\hline Sierra Leone & 39 \\
\hline Liberia & 38 \\
\hline Sao Tome e Principe & 24 \\
\hline Nigeria & 21 \\
\hline Equatorial Guinea & 5 \\
\hline Gambia & 4 \\
\hline Insufficient & 61 \\
\hline Sufficient & 100 \\
\hline
\end{tabular}

Source: International Budget Partnership, (2020), 2019 Open Budget Survey: Nigeria. p.2

Open Budget Survey (OBS) specified that a transparency score of 61 or above indicates a country is likely publishing enough material to support informed public debate on the budget. Open Budget Survey (OBS) went on to show how the transparency score for Nigeria has 
changed over time, with details of the public and the content over time [9] as follows: availability of the budget document to the

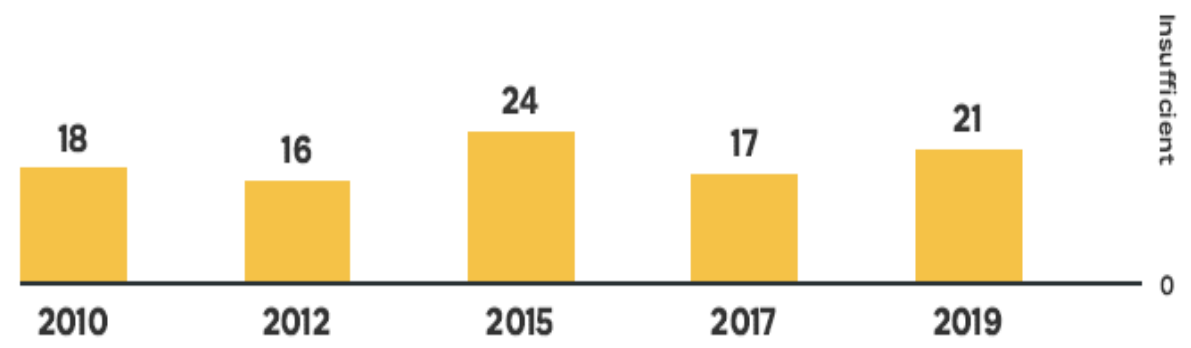

Figure 2. How has the Transparency Score for Nigeria Changed Over Time?

Source. International Budget Partnership, (2020), 2019 Open Budget Survey: Nigeria. p.3

It can be observed from the analysis that Nigeria's transparency score of 21 in the OBS 2019 is near the country's score of 17 in 2017 [9]. The reasons for the change range from the fact that Nigeria started publishing the Citizens Budget online and increased the information provided in the Enacted Budget, thus resulting in increased availability of budget information [9].

On public participation, it has been emphasized that transparency alone is not sufficient for improving governance, stating that inclusive public participation is crucial for realizing the positive outcomes associated with greater budget transparency and outcome [9]. The 2019 OBS also assessed the formal opportunities offered to the public for meaningful participation in the different stages of the budget process, examining the practices of the central government's executive, the legislature, and the supreme audit institution (SAI) using 18 equally weighted indicators [9]. The survey scored each country on a scale from 0 to 100 , with Nigeria having a public participation score of 22 (Out of 100) [9]. The global average is 14 [9].

Table 3. Public Participation in Nigeria Compared to Others

\begin{tabular}{|l|l|}
\hline Global Average & 14 \\
\hline Sierra Leone & 31 \\
\hline Nigeria & 22 \\
\hline Ghana & 15 \\
\hline Gambia & 9 \\
\hline Liberia & 6 \\
\hline Equatorial Guinea & 0 \\
\hline Sao Tome e Principe & 0 \\
\hline Insufficient & 61 \\
\hline Sufficient & 100 \\
\hline
\end{tabular}

Source: International Budget Partnership, (2020), 2019 Open Budget Survey: Nigeria. p.6 
On assessing opportunities for public participation in the budget process, the following scores regarding public involvement in budget formulation, approval, implementation, and audit were reported [9]. Nigeria scored 40 and below in all stages of public participation in the budget process as assessed by 2019 OBS [9].

\section{Legislative oversight}

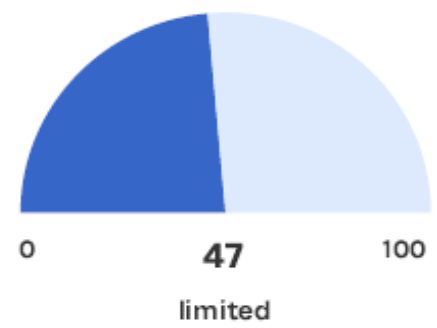

On oversight, Nigeria scored 47 (Limited) on legislative oversight and 72, which is adequate) on audit oversight processes as assessed by 2019 OBS [9], noting that the Implementation (executive) (supreme audit institution) Nigeria's Budget Office of the Federation has established public consultations during budget formulation and e-consultations during budget implementation.

\section{Audit oversight}

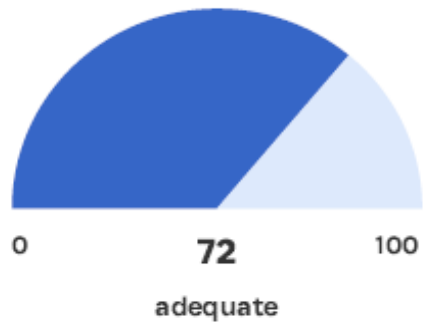

weak: 0 - 40; limited: 41 - 60; adequate: 61 - 100

Figure 4. Legislative and audit oversight

Source: International Budget Partnership, (2020), 2019 Open Budget Survey: Nigeria. p.6

However, the Nigeria's National Assembly provides limited oversight during the planning stage of the budget cycle and limited oversight during the implementation stage [9].

\section{Methods and Materials}

The two sets of questionnaire were used to collect data from the relevant authorities and representatives of citizens on their perception regarding the Enugu state budget allocations and performance and the citizen's involvement in the budget process. The survey was conducted in Enugu East Local Government Area (LGA) of Enugu State.

The study involved 400 persons (50\% males and $50 \%$ females) from age groups 20 to 69 years only. This is because these age groups can make decisions about their welfare and are likely to perceive better and deeper the challenges or otherwise in the budget process, especially as it concerns citizen engagement in the process. The inclusion criteria of respondents in the study were residence in Enugu for not less than 10 years; between 20 and 69 years of age, willingness to participate in the survey, and signing a consent form.

A three-stage multi-stage sampling technique was employed to select study villages, study households, and individual participants. In the first stage, the villages were the sampling units, and 17 out of 33 were selected, using the balloting method of the simple random sampling techniques. In the second stage, the selection of the compounds from the chosen villages using systematic sampling with a frame was done. At the third stage, the households became the sampling units, from which individuals that engaged in the study were picked through simple random sampling. Data collected were analyzed using frequency distribution tables and percentages. The necessary approvals, where applicable, were obtained. Furthermore, informed, and written consents were obtained from the participants. 


\section{Results}

Four hundred questionnaires were distributed. Out of this number, 398 participants (198males and 200 females) responded, giving a response rate of $99.5 \%$. Of the $99.5 \%, 198$ (49.7\%) were male and $200(50.3 \%)$ were females.

\section{Personal Characteristics of Respondents}

Table 4. Personal Characteristics of the Respondents

\begin{tabular}{|c|c|c|c|}
\hline \multirow[t]{2}{*}{ Characteristics } & Male & Female & Total \\
\hline & $\mathrm{n}=198(49.7 \%)$ & $\mathrm{n}=200(50.3 \%)$ & $\mathrm{n}=398$ \\
\hline \multicolumn{4}{|l|}{ Age of Respondents } \\
\hline $20-29 \mathrm{yrs}$ & $18(47.1 \%)$ & $21(52.9 \%)$ & $29(7.3 \%)$ \\
\hline $30-39$ yrs & $55(50.9 \%)$ & $53(49.1 \%)$ & $108(27.1 \%)$ \\
\hline $40-49$ yrs & $89(57.1 \%)$ & $67(42.9 \%)$ & $156(39.2 \%)$ \\
\hline $50-59$ yrs & $22(27.5 \%)$ & $58(72.5 \%)$ & $80(20.1 \%)$ \\
\hline $60-69 \mathrm{yrs}$ & $14(56.0 \%)$ & $11(44.0 \%)$ & $25(6.3 \%)$ \\
\hline \multicolumn{4}{|c|}{ Educational attainment } \\
\hline No education & $8(61.5 \%)$ & $5(38.5 \%)$ & $13(3.2 \%)$ \\
\hline Primary education & $29(61.7 \%)$ & $18(38.3 \%)$ & $47(11.8 \%)$ \\
\hline Secondary education & $58(43.3 \%)$ & $76(56.7 \%)$ & $134(33.7 \%)$ \\
\hline Tertiary education & $103(50.5 \%)$ & $101(49.5 \%)$ & $204(51.3 \%)$ \\
\hline \multicolumn{4}{|l|}{ Residence } \\
\hline Urban & $169(58.7 \%)$ & $119(41.3 \%)$ & $288(72.4 \%)$ \\
\hline Rural & $16(40.0 \%)$ & $24(60.0 \%)$ & $40(10.0 \%)$ \\
\hline Semi-urban & $43(61.4 \%)$ & $27(38.6 \%)$ & $70(17.6 \%)$ \\
\hline
\end{tabular}

Female respondents were slightly greater (200 [50.3\%]) in number than males (198 [49.7\%]). The findings revealed that most of the respondents were in the age range of $40-49$ years $(39.2 \%)$, followed closely by the age range $30-39$ year (27.1\%). Educational attainment majority of the respondents had secondary level education and above $(33.7 \%$ and $51.3 \%$ ), respectively. Primary education attainment showed $11.8 \%$ of respondents, while no education had the least $(3.2 \%)$. Most respondents $(72.4 \%)$ were urban residents as at the time of the study, followed by the semiurban resident $(17.6 \%)$, respondents residing in the rural areas were least (10\%).

\section{Factors that Influence the Release of Funds in the State}

On the factors that influence the release of funds, the respondents indicated that some of the factors that influence allocation and release are as in the Table below:

Table 5. Factors that Influence Allocation and Release $(n=398)$

\begin{tabular}{|l|l|}
\hline Factors & \% Response \\
\hline Poor allocation/release of funds from federal sources & 60 \\
\hline Low IGR to supplement federal funding & 36 \\
\hline Competing demands of another sector & 38 \\
\hline Bureaucratic financial management processes & 58 \\
\hline Weak political commitment to achieve policy objectives & 52 \\
\hline Pressure from donors and development partners in the state & 52 \\
\hline
\end{tabular}


International declarations led by institutions such as United African Union 27

and Federal reforms agreed at the National Council of Health, among others.

Most (60\%) stakeholders interviewed agreed that the major health financing challenge in Enugu state is poor allocation and release of funds from the federal government. This view was followed by weak political commitment and pressure from donors and development partners in the State $(52 \%$ and $53 \%)$, respectively).

\section{Citizens' Level of Participation (Engagement, Scope, and Mechanisms) in the Health Budget Process} engagement in the budget process, the scope of engagement, and the mechanisms for the engagement.

\section{Engagement of Citizens in the Budgetary Process}

Responses to the government's invitation of inputs from citizens in the budgetary process revealed that $338(85 \%)$ respondents disagreed, $44(11 \%)$ respondents agreed, with $16(4 \%)$ being undecided, as illustrated in Table 6 .

Responses to this objective revealed
different levels of opinion regarding

Table 6. Engagement of Citizens in the Budgetary Process $(n=398)$

\begin{tabular}{|l|l|l|l|l|l|}
\hline Study Statement & Strongly agree & Agree & Undecided & Disagree & Strongly disagree \\
\hline \multirow{2}{*}{$\begin{array}{l}\text { Enugu state government } \\
\text { invites inputs of citizens } \\
\text { into the budget }\end{array}$} & 12 & 32 & 16 & 330 & 8 \\
\hline $\begin{array}{l}\text { Timing of the input of the } \\
\text { citizens is given a priority } \\
\text { in the budgetary process. }\end{array}$ & 0 & $(8 \%)$ & $(4 \%)$ & $(83 \%)$ & $(2 \%)$ \\
\hline $\begin{array}{l}\text { The invitation for } \\
\text { participation comes early } \\
\text { in the budgetary process }\end{array}$ & 8 & & & 354 & 44 \\
\hline \multirow{2}{*}{$\begin{array}{l}\text { The invitation for } \\
\text { participation comes at any } \\
\text { time during the budgetary } \\
\text { process }\end{array}$} & $334)$ & 12 & & $(89 \%)$ & $(11 \%)$ \\
\cline { 2 - 6 } & $(84 \%)$ & $(3 \%)$ & 0 & 366 & 12 \\
\hline $\begin{array}{l}\text { Citizen participation is } \\
\text { used more frequently at the } \\
\text { end of the process }\end{array}$ & 28 & 16 & 40 & $(92 \%)$ & $(3 \%)$ \\
\cline { 2 - 6 } & $(7 \%)$ & $(4 \%)$ & $(10 \%)$ & $(2 \%)$ & 0 \\
\hline
\end{tabular}

Similarly, regarding whether the timing of inputs of the citizens is given a priority, all 398 $(100 \%)$ respondents disagreed, with 354 respondents (89\%) just disagreeing and 44 respondents $(11 \%)$ strongly disagreeing. This issue was cross-examined with whether the invitation for participation comes early in the budgetary process. The response to this also showed that out of the 398 responses, 378 (95\%) respondents disagreed (92\% disagreeing and 3\% strongly disagreeing). Correspondingly, the majority of them, $350(88 \%)$, agreed that the invitation for participation comes at any time during the budgetary process.

It is worthy of note that of the 398 respondents, $330(83 \%)$ disagreed with the statement that citizens' participation is used more frequently at the end of the budget process. From the above findings, it can be deduced that citizens, to a great extent, are not engaged in the budget process. 


\section{Scope of Engagement of the Citizens}

On the scope of engagement with the citizens, the majority of the respondents, 338 (85\%), disagreed with all statements regarding input being more beneficial during the preparation stage rather than the budgetadoption phase, the existence of instances of budget input occurring early in the process, participation being open to large numbers of people, and representative of the community. However, 60 (15\%) respondents remained undecided on all statements, as in the chart below.

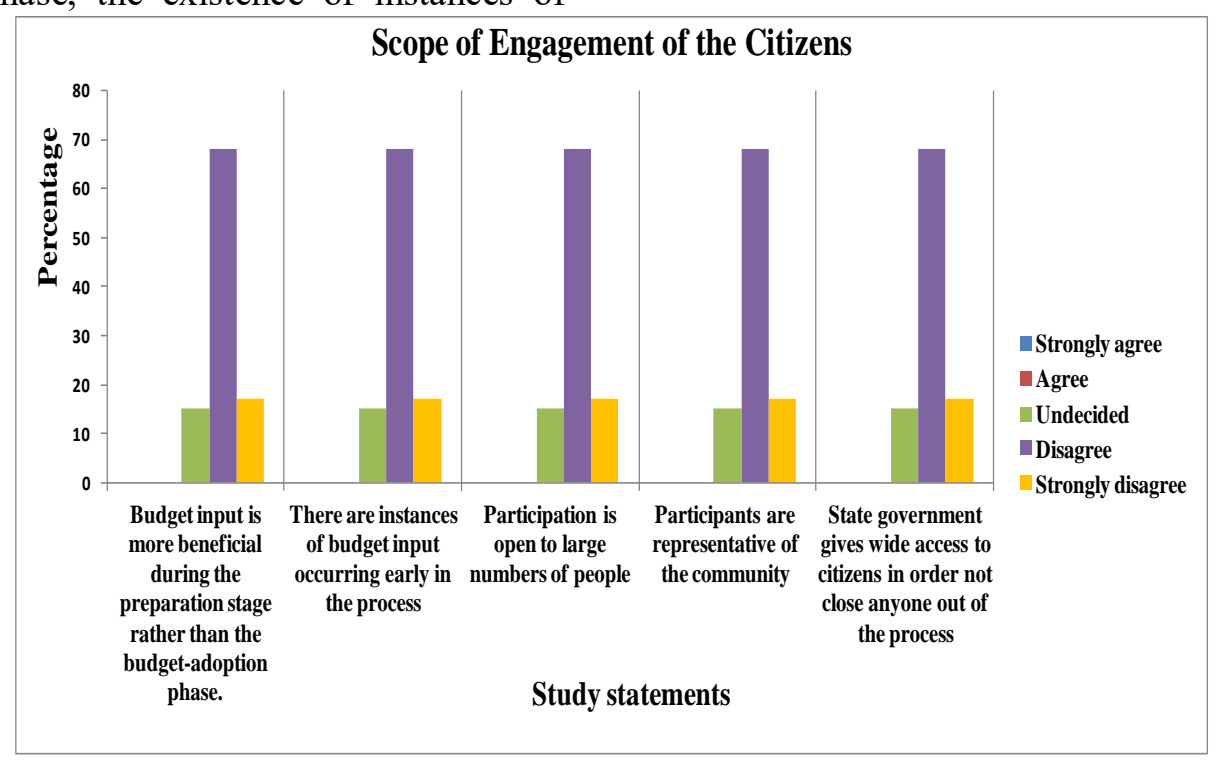

Figure 5. Scope of Engagement of the Citizens $(n=398)$

\section{Mechanisms used to Engage Citizens in the Budget Process}

On the mechanism of engagement, out of 398 respondents, 338 (85\%) disagreed with all the statements about the use of public meetings, focus group discussions, citizens surveys, or town meetings to elicit citizen participation in the budget process. Noteworthy is the opinion regarding the use of budget committees, where $107(27 \%)$ respondents agreed with the statement, while $263(66 \%)$ respondents disagreed.

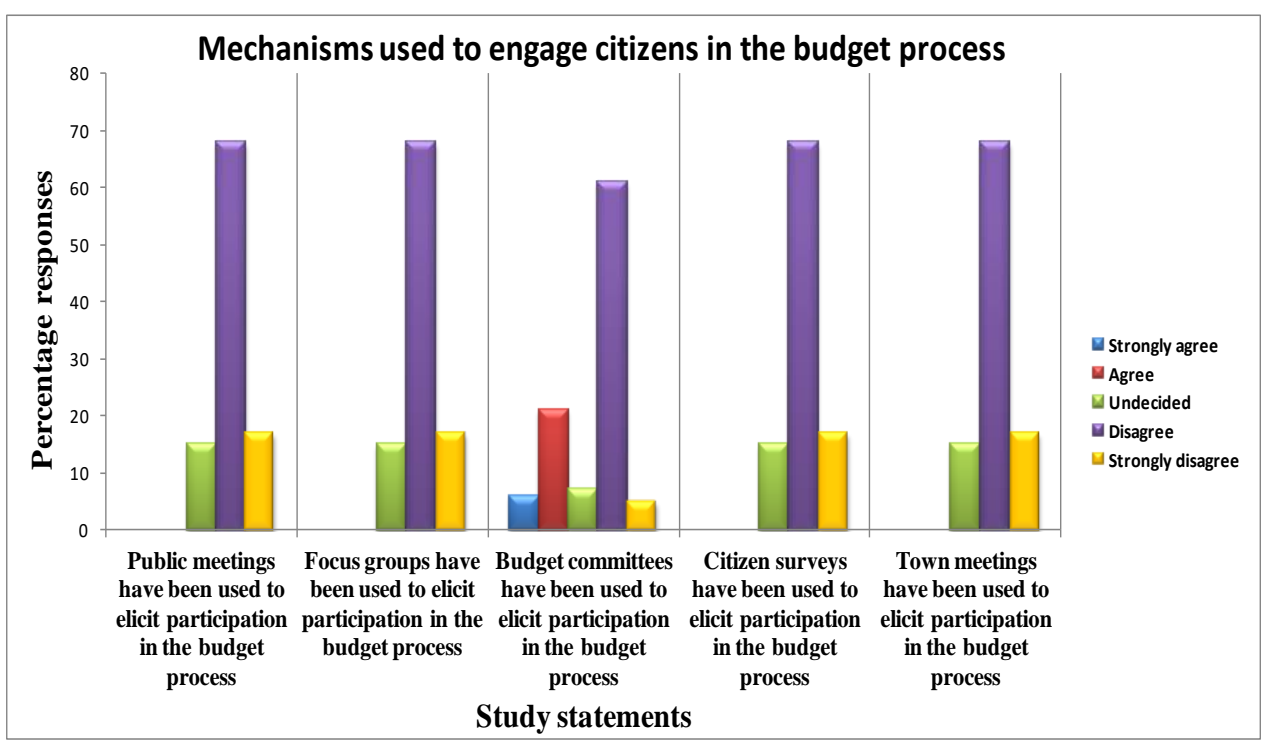

Figure 8. Mechanisms used to Engage Citizens in the Budget Process $(n=398)$ 
It can be seen from the responses above that the perception of the citizens regarding mechanisms and scope of engagement of citizens in the budget process are similar, except for the use of budget committees where 107 (27\%) agreed, and 28 (7\%) remained undecided.

\section{Citizens' Knowledge about the Goals of Citizen Participation in Budget Process}

The governments' goal of citizens' citizens. Responses to whether the goal is informing decision making revealed that the majority (227 [57\%]) of the respondents disagreed, with 139 (35\%) being undecided, leaving only $32(8 \%)$ respondents with the agreement. To whether the government goal is educating citizens on the budget, $200(50 \%)$ respondents disagreed, $80(20 \%)$ respondents were undecided, while 118 (30\%) respondents agreed. participation is not clearly understood by the

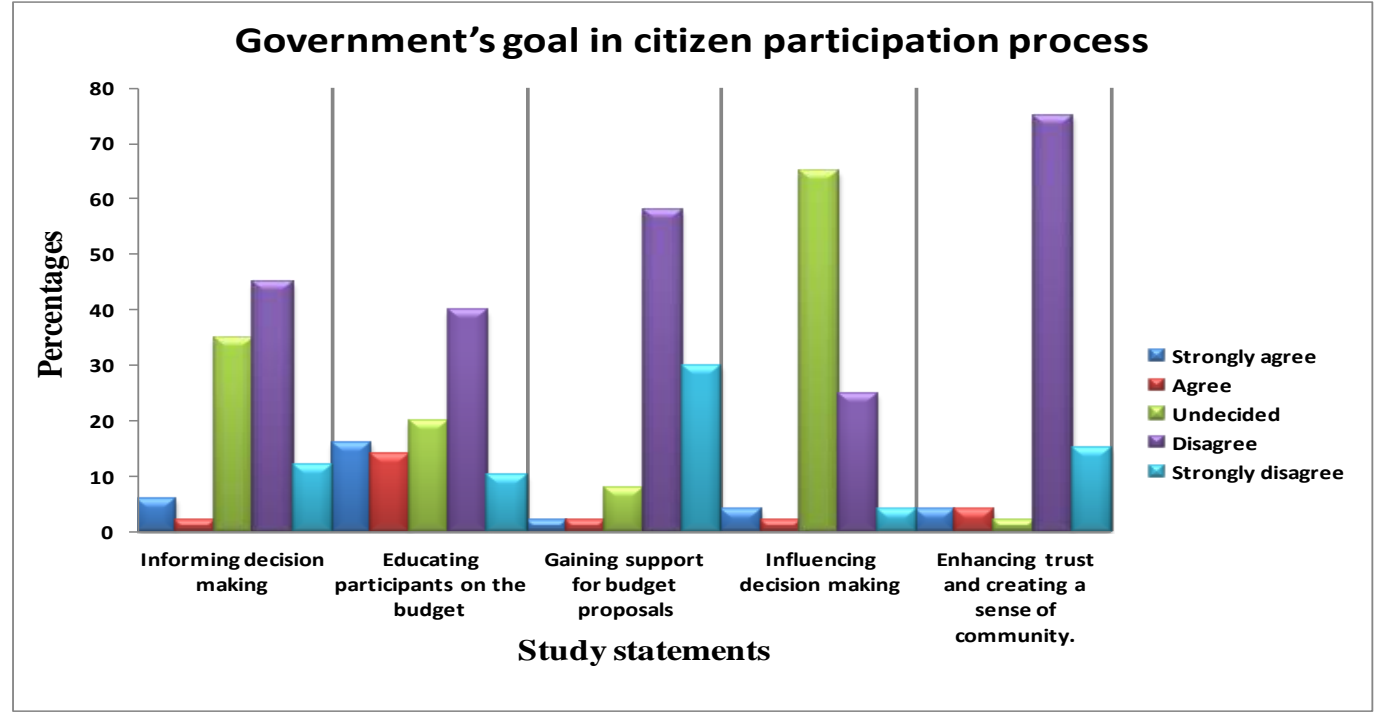

Figure 7. Government's Goal in Citizen Participation Process $(\mathrm{n}=398)$

Responses to whether the goal is to gain support for the budget process stood out, with the majority (350 [88\%]) of the respondents disagreeing; $32 \quad(8 \%)$ respondents were undecided, and 16 (4\%) agreed. On influencing decision-making as the goal of government, the majority $(259[65 \%])$ of the respondents were undecided. This was followed by those that disagreed 115 (29\%), with the respondents that agreed coming at least $24(6 \%)$. To the issue of enhancing trust and creating a sense of community as a goal of government for citizens' participation, about $358 \quad(90 \%)$ respondents disagreed, while $32(8 \%)$ were in agreement and only $8 \quad(2 \%)$ remained undecided. The responses are as displayed in the chart below.

It can be deduced that the respondents disagreed with all the statements regarding what the goal of the government is, except for influencing decisions where the majority remained undecided, which might imply a disagreement too since the respondent expressed a negative opinion to the other statements.

There was observed gaps in the level of knowledge among participants regarding citizen participation in the budget process. It is also noted that there is a limited number of studies on citizens' participation at the State and local government levels.

\section{Discussion}

\section{Factors that Influence the Release of Funds in the State}

All respondents agreed that the major health financing challenge in Enugu state is poor allocation and release of funds. Although some 
of the budgeted funds are contributions from donors on programs, those funds expected from partners have not yet been added to the funds utilized in the health sector. Furthermore, the budget release was indicated by respondents to be very low and due to delays from the federal government sources.

Fundamentally, developing strong health budget envelopes calls for strong and collaborative commitment from the government at all levels through engagement with the relevant ministries, decision-makers, and their stakeholders.

In the budgeting process, the allocation of resources to various institutions and for diverse purposes is basically a political rather than a purely bureaucratic process. How the budgets are formed, allocated, and used in the health sector is at the core of the Universal Health Coverage (UHC) agenda [1]. Similarly, supporting a fair distribution of resources across populations and/or geographical areas is likely to have a direct impact on health sector outputs [3].

\section{Citizens' Level of Participation (Engagement, Scope, and Mechanisms) in the Health Budget Process}

The findings showed that citizens do not participate at any stage in the budget process. This does not differ from the reports of the Open Budget Survey (OBS) conducted in on transparency of the budget process. Nigeria has a transparency score of 21 (out of 100) compared to the other 116 countries, thus ranking 97 out of 117 countries [9], and the global average reported as 45 . It can be observed from the analysis that Nigeria's transparency score of 21 in the OBS 2019 is near the country's score of 17 in 2017 [9], stating that the reasons for the change range from the fact that Nigeria started publishing the Citizens Budget online and increased the information provided in the Enacted Budget, thus resulting in increased availability of budget information.
On public participation, transparency alone is not sufficient for improving governance, and inclusive public participation is crucial for realizing the positive outcomes associated with greater budget transparency and outcome [9]. The 2019 OBS also surveyed the formal opportunities offered to the public for meaningful participation in the different stages of the budget process, scoring each country on a scale from 0 to 100 , with Nigeria having a public participation score of 22 (Out of 100), [9] and the global average was reported as 14.

On oversight, Nigeria scored 47 (Limited) on legislative oversight and 72 (which is adequate) on audit oversight processes as assessed by 2019 OBS [9]. The Implementation (executive) Nigeria's Budget Office of the Federation has established public consultations during budget formulation and e-consultations during budget implementation. However, Nigeria's National Assembly provides limited oversight during the planning stage of the budget cycle and limited oversight during the implementation stage [9].

International Budget Partnership (2020) emphasized that though Nigeria's Budget Office of the Federation has established public consultations during budget formulation and econsultations during budget implementation but, to further strengthen public participation in the budget process [9], there is need also prioritize the expansion of mechanisms during budget formulation through implementation to monitoring, that engages any civil society organization or member of the public who wishes to participate.

The Nigerian government should actively engage with vulnerable and underrepresented communities, directly or through civil society organizations representing them; and Nigeria's Office of the Auditor-General for the Federation should prioritize the establishment of formal mechanisms for the public to assist in developing its audit program and to contribute to relevant audit investigations [9]. 


\section{Citizens' Knowledge about the Goals of Citizen Participation in Budget Process}

Respondents indicated little or no knowledge of the goals of government in the budget process. This might be from the absence of engagement or a low level of engagement. For participatory budgeting in developing countries, it is important to focus by underlining its merits as promoting social justice and good governance and transparency by providing the government with information and facts that improve allocative or technical efficiency. This is true as public inputs most times recommend innovative solutions that would not have been obvious from traditional modes of decision making.

\section{Conclusion}

Improved budget outcome and thus good governance requires the greater and meaningful engagement of the citizens the unity between (those who have the information) and the government (Those who need the information). To move towards achieving continuous improvement in budget outcomes, the government should develop strategies for citizens' interaction and participation through all stages of the budget process.

This translates into a redefinition of the budget process, and mechanisms to better meet citizens' expectations and schedules. Engaging large and varied groups/bodies that are

\section{References}

[1] Rajan, D., Barroy, H, and Stenberg K., (2016). Budgeting for health. In: Schmets G, Rajan D, Kadandale S, editors. Strategizing national health in the 21st century: a handbook. Chapter 8. Geneva: World Health Organization. http://apps.who.int/iris/bitstream/handle/10665/2502 21/9789241549745-chapter8eng.pdf? sequence $=11 \&$ isAllowed $=y$.

[2] Save the Children, (2012). Health Sector Budget Advocacy: A guide for civil society organisations. representatives of others in all phases of budgeting would be the star strategies that will ultimately give a fair picture of concrete citizens' agendas. When the participation involves only one stakeholder group, it might imply that it is only the voice of a particular section of the community or special group that is being heard, which might lead to achieve the goal of widespread representation and engagement.

In other words, participation in the budget process should entail efforts to bring all relevant stakeholders together through the institutionalization of appropriate structures, scope, and mechanisms to actively and meaningfully engage relevant citizens' groups towards a well-defined and prioritized goal in all the phases of the budget process.

\section{Conflict of Interest}

No conflict of interest in this study.

\section{Acknowledgement}

I wish to express my profound gratitude to the numerous individuals and institutions (State Ministries of Health and Finance) that supported me during the course of this survey. Their immense knowledge, profound experience, and expertise in data harvest, collection, and collation have helped me to complete this study successfully. It would have been a much more daunting task without their support.

https://www.who.int/pmnch/media/news/2012/2012 05 health_sector_budget_advocacy.pdf.

[3] Cashin, C., (2016). Health financing policy: the macroeconomic, fiscal, and public finance context. Washington (DC): World Bank Group. http://documents.worldbank.org/curated/en/3940314 67990348481/Health-financing-policy-themacroeconomic-fiscal-and-public-finance-context. [4] Iloh C. E. \& Nwokedi M. E., (2016). Budget Processes and Participatory Budgeting in Nigeria: Lessons from Latin America. ANSU Journal of Arts and Social Sciences, 5(1): 135-154. https://oidp- 
afrique.org/wp-content/uploads/2020/04/NigeriaBudget_Processes_and_Participatory_Budge.pdf. [5] Bisong, Daniel Bisong and Ogwumike, Jam Hill Chiddy, (2020). Citizen Participation in Budgetary Processes and Effective Governance in Nigeria Journal of Public Administration and Social Welfare Research: 5(2) 2020 ISSN E-ISSN 2504-3597 PISSN 2695-2440.

https:/iiardpub.org/get/JPASWR/VOL. $\% 205 \% 20 \mathrm{~N}$

O.\%202\%202020/Citizen \%20Participation $\% 20 \mathrm{in} \% 2$ 0Budgetary.pdf.

[6] Klimovsky, D., (2017). Participatory Budgeting in Slovakia: Experience from Bratislava and Ružomberok in Participatory Budgeting Klimovsky D.(ed). Project "Capacity Building of NAPA for Open Local Governance".
[7] Shah, Anwar, (2007). Participatory Budgeting: Public Sector Governance and Accountability. Washington, DC: World Bank. https://openknowledge.worldbank.org/handle/10986/ 6640.

[8] Anissa, D. B. and Habib, A., (2021). Corporate Budget Governance Through the Operating Managers Commitment: What is the problem? https://www.pubtexto.com/journals/journal-ofeconomic-and-business-studies/fulltext/corporatebudget-governance-through-the-operatingmanagers-commitment-what-is-the-problem. [9] International Budget Partnership, (2020). 2019 Open Budget Survey: Nigeria. https:/www.internationalbudget.org/open-budgetsurvey/country-results/2019/nigeria. 


TEXILA
JOURNAL
ejournal.assist@tau.edu.gy
wwww.texilajournal

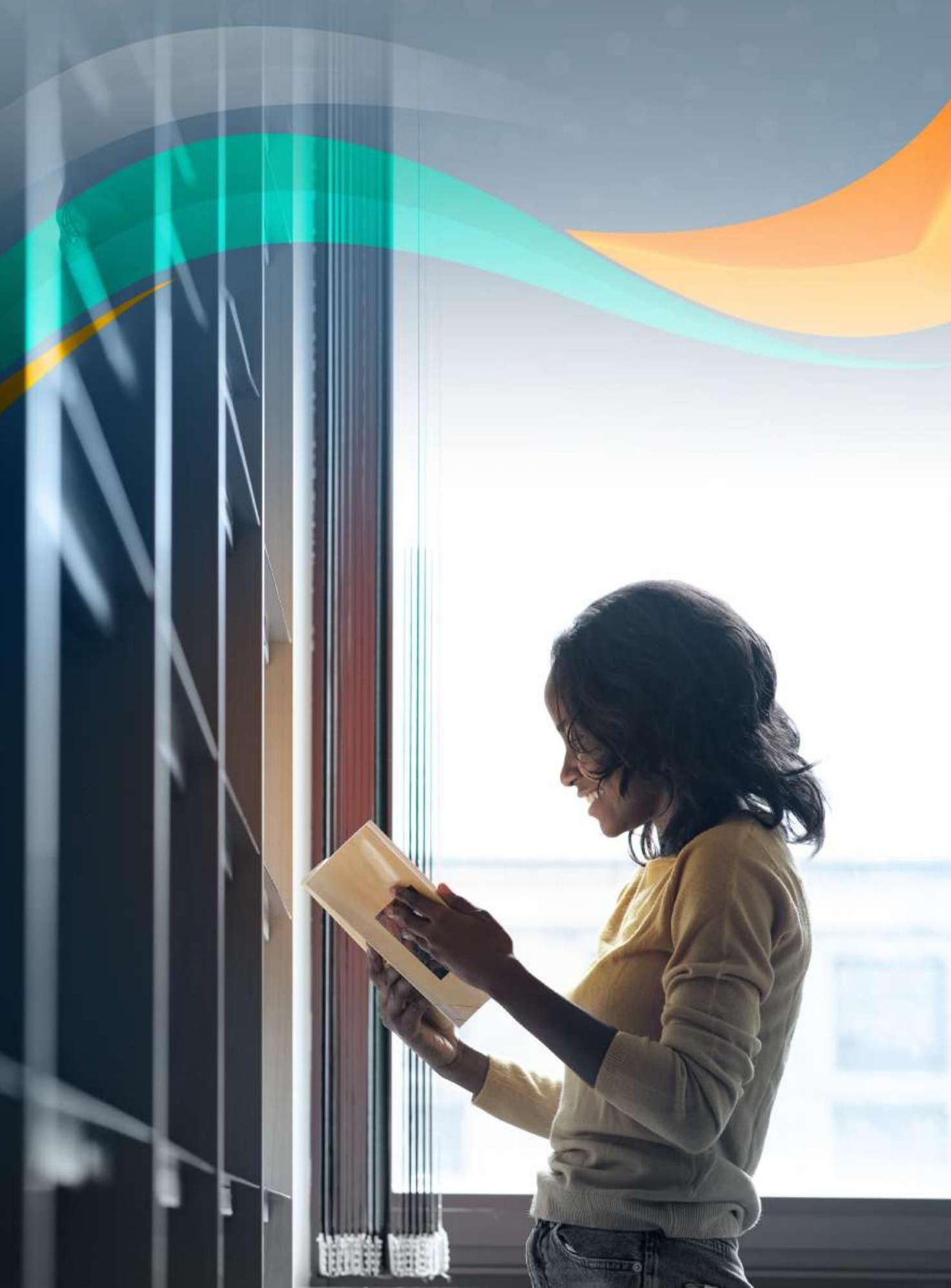

